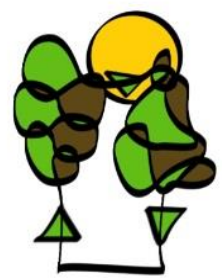

SUSTAINABLE FOREST MANAGEMENT RESEARCH INSTITUTE UNIVERSIDAD DE VALLADOLID-INIA

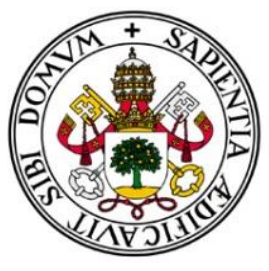

Universidad deValladolid

\title{
Effects of climate change on growth of pine species in Mediterranean environments
}

\section{DOCTORAL THESIS}

\section{Jorge Olivar Ruiz Palencia, 2013}





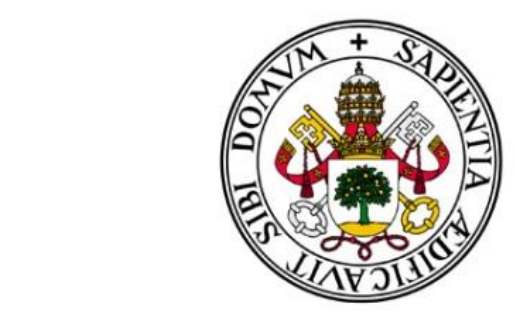

\title{
Universidad deValladolid
}

ESCUELA TÉCNICA SUPERIOR DE INGENIERÍAS AGRARIAS

INSTITUTO UNIVERSITARIO DE INVESTIGACIÓN EN GESTIÓN FORESTAL SOSTENIBLE

TESIS DOCTORAL:

\section{EFFECTS OF CLIMATE CHANGE ON GROWTH OF PINE SPECIES IN MEDITERRANEAN ENVIRONMENTS}

\author{
EFECTOS DEL CAMBIO CLIMÁTICO EN EL \\ CRECIMIENTO DE LOS PINOS EN AMBIENTES \\ MEDITERRÁNEOS
}

Presentada por Jorge Olivar Ruiz para optar al grado de doctor por la Universidad de Valladolid

Dirigida por:

Dr. Felipe Bravo Oviedo 



\section{CONTENTS}

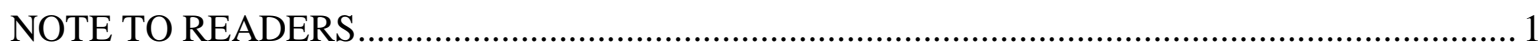

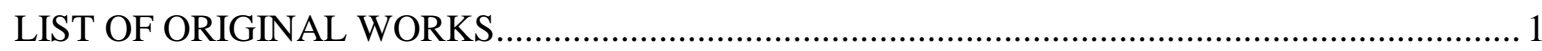

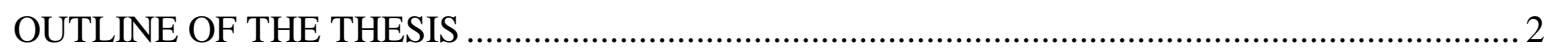

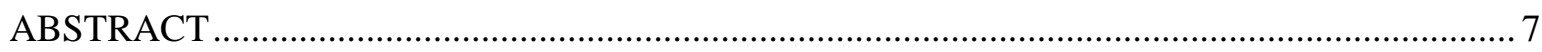

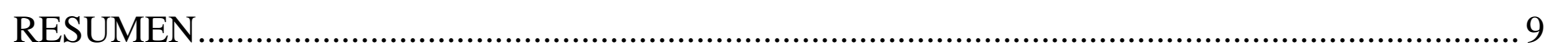

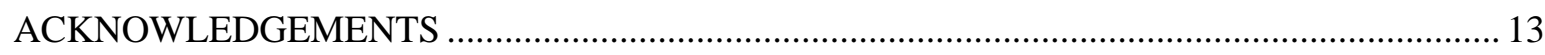

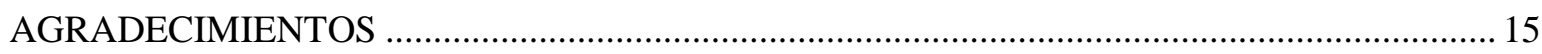

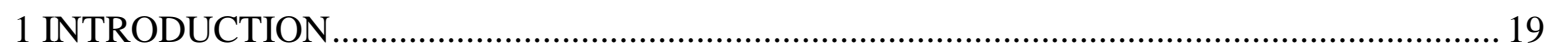

1.1 Mediterranean environments and climate change ....................................................... 19

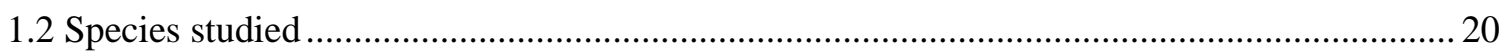

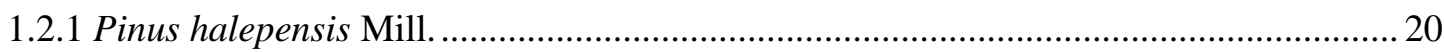

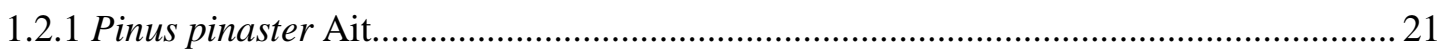

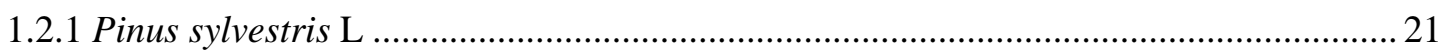

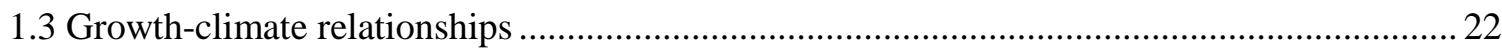

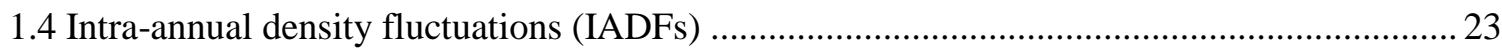

1.5 Effects of thinning on growth dynamics and growth-climate relationships ..........................2 24

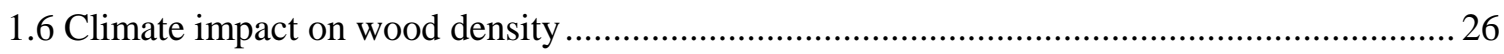

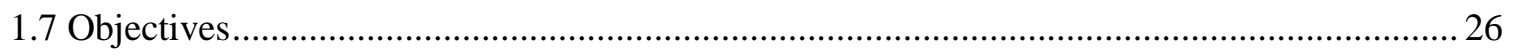

1.7.1 Climate impact on growth dynamic and intra-annual density fluctuations in Aleppo pine (Pinus halepensis) trees of different crown classes (Study I)...........................26

1.7.2 Changes in climate-growth relationships and IADF formation over time in Mediterranean pine species (Pinus halepensis, P. pinaster and P. sylvestris) in

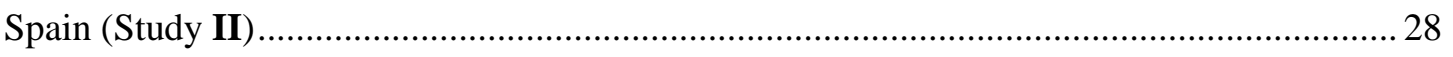

1.7.3 Effects of thinning on growth dynamics and growth-climate relationships in Aleppo pine (Pinus halepensis) trees of different crown classes (Study III)......................... 28 
1.7.4 Climate impact on wood density in Pinus halepensis, P. pinaster and P.

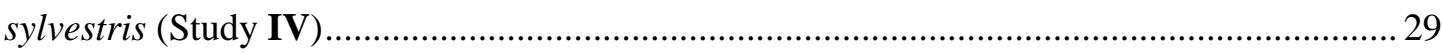

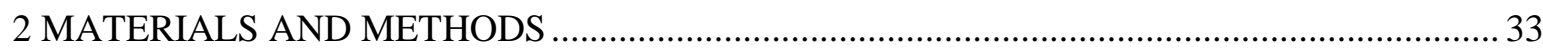

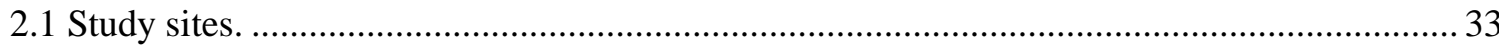

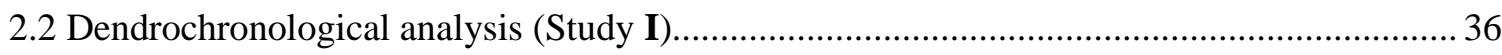

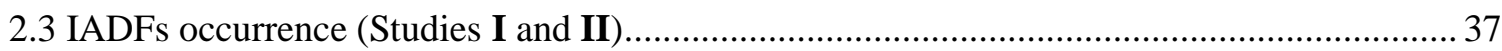

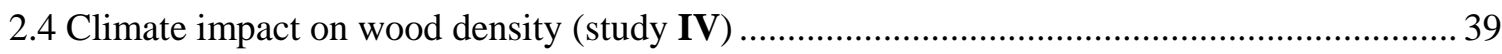

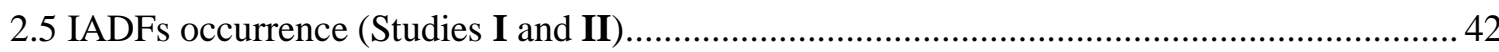

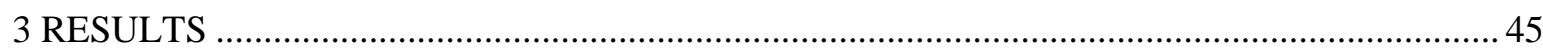

3.1 Dendrochonological study of Pinus halepensis trees of different crown classes (Study I)

3.2 Climate-growth relationships over time in Mediterranean pine species (Pinus halepensis, $P$. pinaster and $P$. sylvestris) in Spain (Study II)

3.3 IADF formation over time in Mediterranean pine species (Pinus halepensis, $P$. pinaster and P. sylvestris) in Spain (Studies I and II)

3.4 Effects of thinning on growth dynamics and growth-climate relationships in Aleppo pine (Pinus halepensis) trees of different crown classes (Study III)

3.5 Climate impact on wood density in Pinus halepensis, Pinus pinaster and Pinus

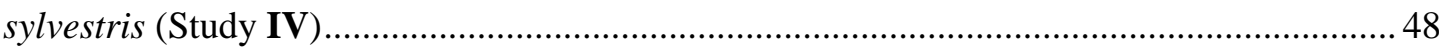

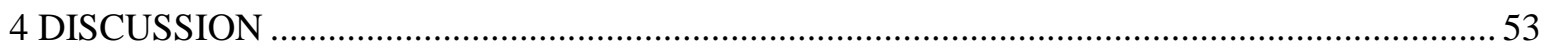

4.1 Dendrochonological study of Pinus halepensis trees of different crown classes (Study I)

4.2 Climate-growth relationships over time in Mediterranean pine species (Pinus halepensis, $P$. pinaster and P. sylvestris) in Spain (Study II)

4.3 IADF formation over time in Mediterranean pine species (Pinus halepensis, $P$. pinaster and $P$. sylvestris) in Spain (Studies I and II) .56

4.4 Effects of thinning on growth dynamics and growth-climate relationships in Aleppo pine (Pinus halepensis) trees of different crown classes (Study III) 
4.5 Climate impact on wood density in Pinus halepensis, Pinus pinaster and Pinus sylvestris (Study IV)

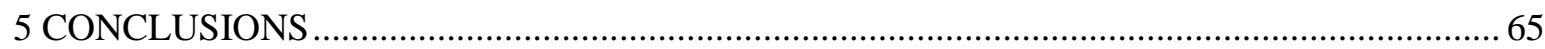

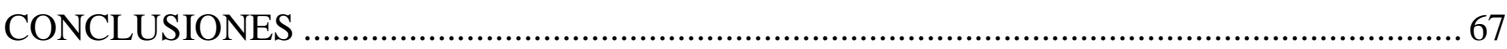

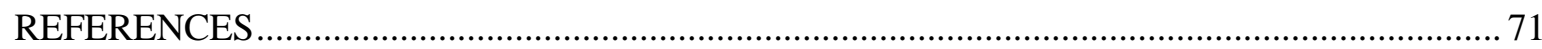

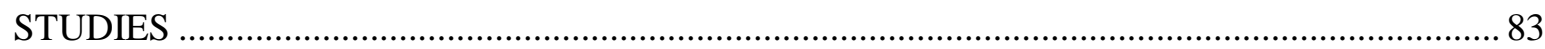

Study I: Climate impact on growth dynamic and intra-annual density fluctuations in Aleppo pine (Pinus halepensis) trees of different crown classes .................................. 87

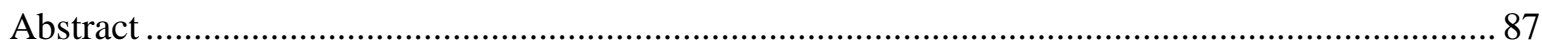

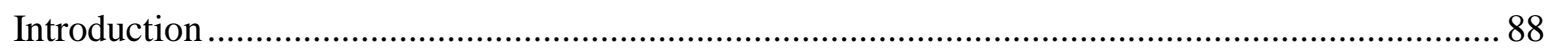

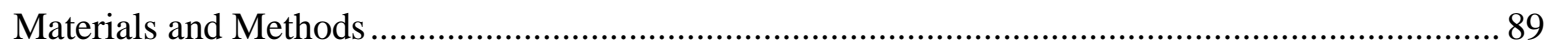

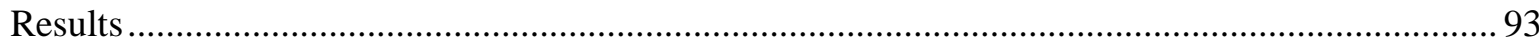

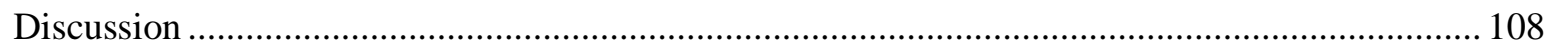

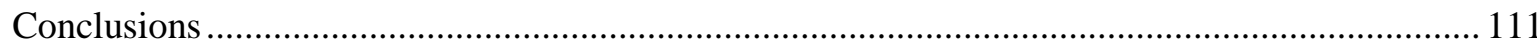

Study II: Changes in climate-growth relationships and IADF formation over time in Mediterranean pine species (Pinus halepensis, $P$. pinaster and $P$. sylvestris) in

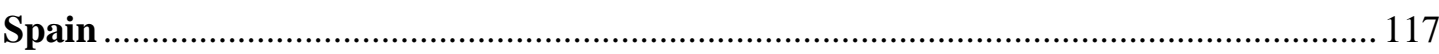

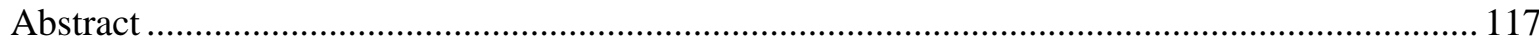

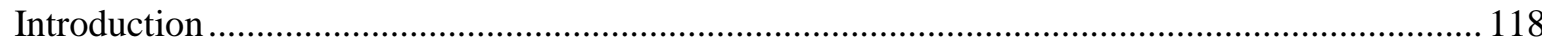

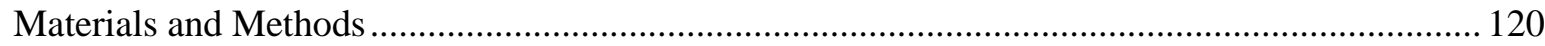

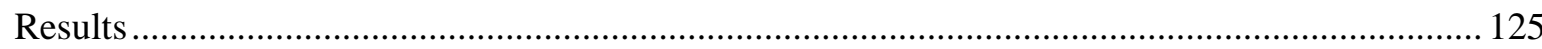

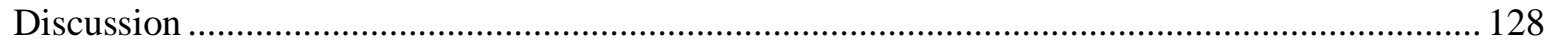

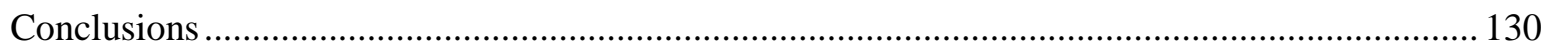

Study III: Thinning has a positive effect on growth dynamics and growth-climate relationships in Aleppo pine (Pinus halepensis) trees of different crown classes .......... 139

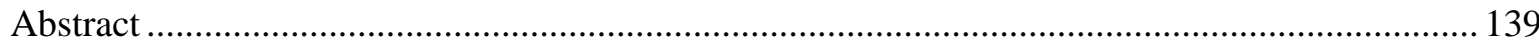

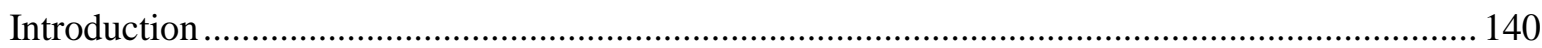




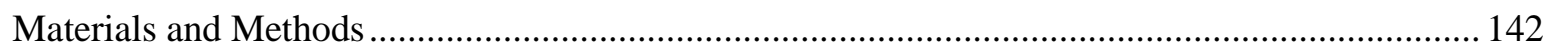

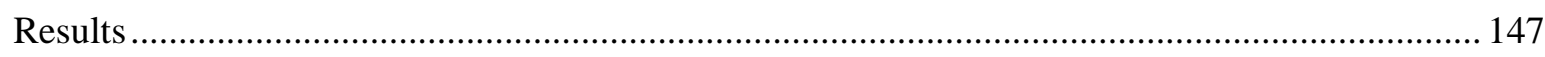

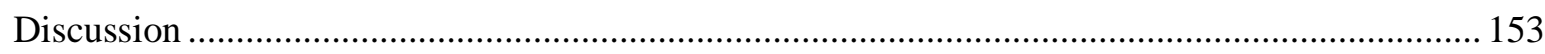

Climate impact on wood density in Pinus halepensis, Pinus pinaster and Pinus

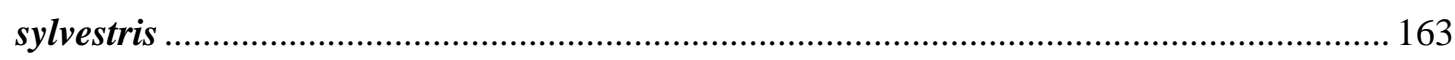

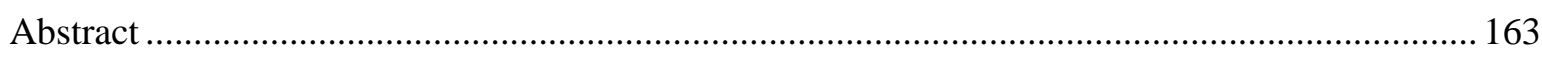

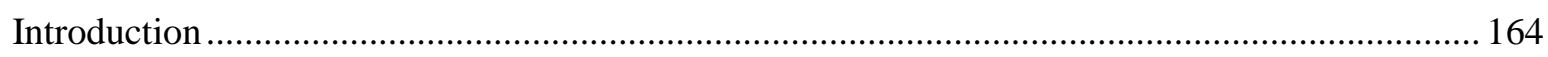

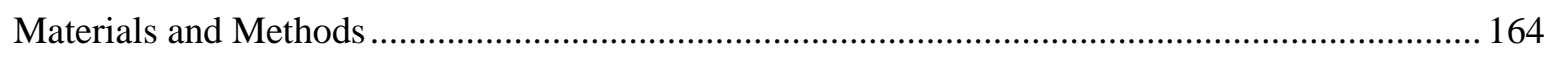

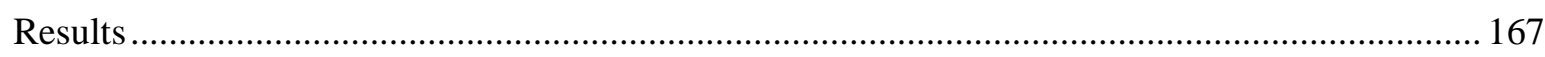

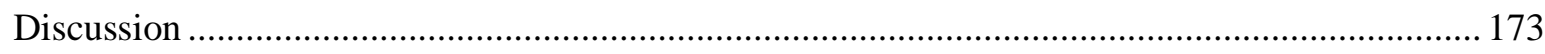

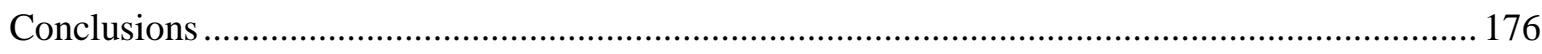




\section{NOTE TO READERS}

This thesis is based on four original works, which are referred to in the text with Roman numerals (I, II, III, and IV), published or under revision in different international journals. Each article constitutes one of the studies or chapters of the thesis. Authors, coauthors, and the stage of the publication are presented below.

Previously to the presentation of each study, the reader will find the outline of the thesis and an abstract of the thesis written in English and Spanish. Then, a summary of the whole thesis which includes an introduction with the general and specific objectives, the main methodologies and analyses employed, the main results and a general discussion. After that, the reader will find the four studies and the general conclusions of the thesis.

\section{LIST OF ORIGINAL WORKS}

I Olivar, J., Bogino, S., Spiecker, H., Bravo, F., 2012. Climate impact on growth dynamic and intra-annual density fluctuations in Aleppo pine (Pinus halepensis) trees of different crown classes. Dendrochronologia 30, Issue 1: 35-47.

II Olivar, J., Bogino, S., Spiecker, H., Bravo, F., 2013. Changes in climate-growth relationships and IADF formation over time in Mediterranean pine species (Pinus halepensis, $P$. pinaster and P. sylvestris) in Spain. Submited to European Journal of Forest Research.

III Olivar, J., Bogino, S., Rathgeber, C.B.K., Bonnesoeur, V., Leporati, J., Ordoñez, C., Bravo, F., 2013. Thinning has a positive effect on growth dynamics and growth-climate relationships in Aleppo pine (Pinus halepensis) trees of different crown classes. Accepted with Major Revision in Annals of Forest Science.

IV Olivar, J., Rathgeber, C.B.K., Bravo, F., 2013. Climate impact on wood density in Pinus halepensis, Pinus pinaster and Pinus sylvestris. Manuscript. 


\section{OUTLINE OF THE THESIS}

The thesis focuses on evaluating the impact of climate on pine trees growing under Mediterranean conditions. To accomplish these general objective four studies have been developed. First, study I identified relationships between radial growth and climate for different crown classes of Aleppo pine (Pinus halepensis Mill.), quantified the presence of intra-annual density fluctuations (IADFs) according to crown class and cambial age and established the relationships between IADFs and climate. Secondly, study II identified and compared radial growth-climate relationships along time for $P$. halepensis, $P$. pinaster and P.sylvestris in Spain, quantified and compared the presence of intra-annual density fluctuations (IADFs) on the three species and defined the climatic variables that are associated with the occurrence of IADFs. Study III identified the main climatic drivers of intra-annual growth of Aleppo pine, analysed witch crown class is more affected by water stress and investigated if the reduction of stand density through thinning decreases its vulnerability to water stress. Finally, study IV identified the main climatic driver of the radial growth and wood density patterns for $P$. halepensis, $P$. pinaster and $P$. sylvestris; and established the relationships between tree-ring width and wood density. Fig. A shows the conceptual model of the thesis topics and studies carried out. 


\section{EFFECTS OF CLIMATE CHANGE ON GROWTH OF}

\section{PINE SPECIES IN MEDITERRANEAN ENVIRONMENTS}

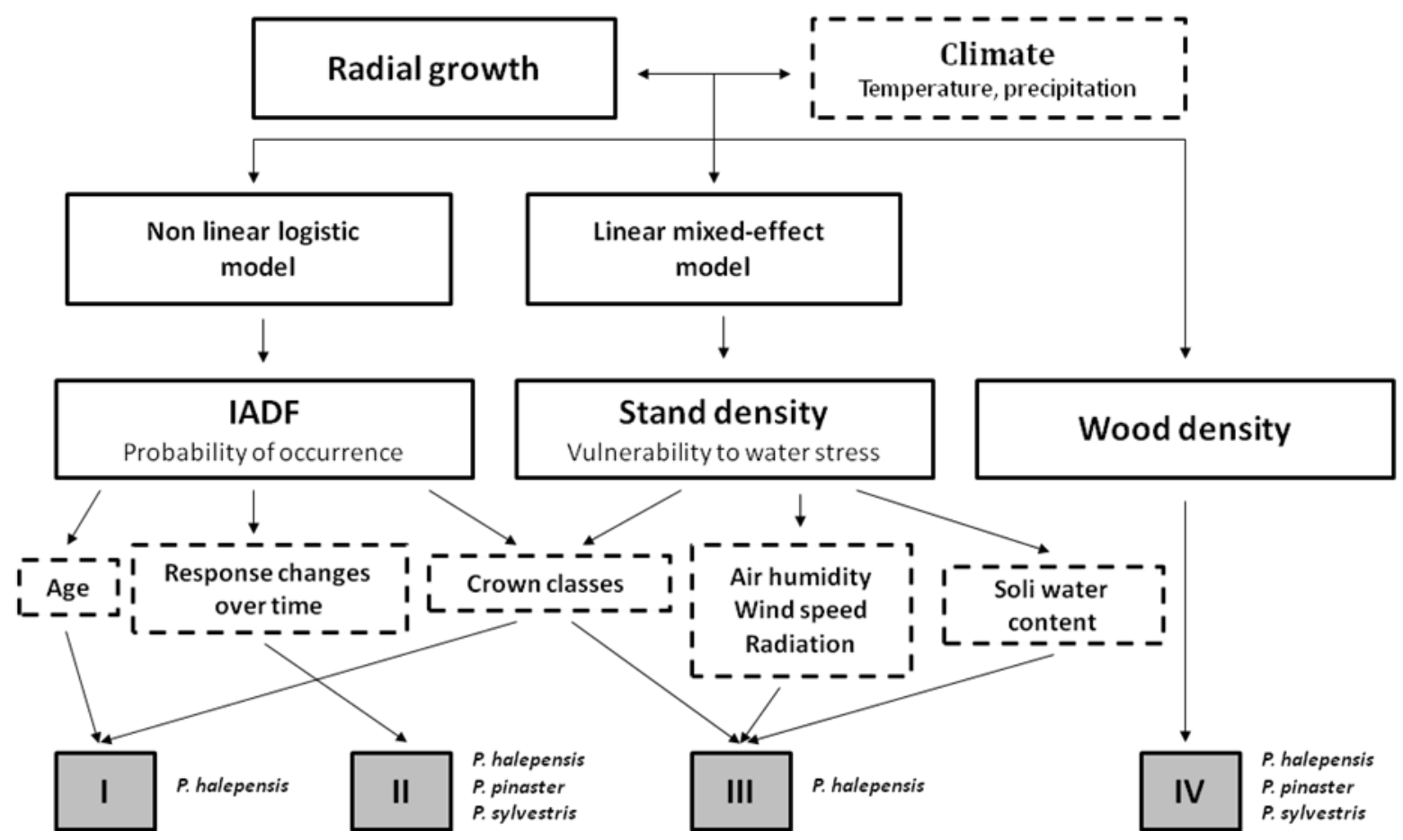

Fig. A: Conceptual model of the thesis. Key factors (solid squares); main measured variables (discontinuous lines squares); studies (Roman numerals), species and links between them are indicated. 
Olivar (2013) 
Olivar (2013) 


\begin{abstract}
Understanding growth-climate relationships is a crucial issue to develop forest management strategies to mitigate climate change impact. During the second half of the $20^{\text {th }}$ century the Mediterranean area has experienced an increase in the mean annual temperature, a decrease in the mean annual precipitation, and an increase in the frequency of severe drought periods. However, in western Mediterranean region winter and spring precipitations have increased while summer precipitation has decreased. Dendroclimatological techniques were applied in 28 sampling sites located in Spain to analyse the association between Pinus halepensis (8 sampling sites) P. pinaster (9 sampling sites) and P. sylvestris (11 sampling sites) and climatic variables in Mediterranean environments. The objectives of this thesis were: a) to identify and compare inter-annual growth-climate relationships along time for $P$. halepensis, $P$. pinaster and $P$. sylvestris in Spain, b) to quantify and compare the presence of intra-annual density fluctuations (IADFs) on the three species and to define the climatic variables that are associated with its occurrence, c) to identify the main climatic drivers of intra-annual growth of $P$. halepensis, d) to analyse crown class differences in the effect of water stress, e) to investigate if the reduction of stand density through thinning decreases its vulnerability to water stress, f) to establish the relationships between climate and wood density for $P$. halepensis, $P$. pinaster and $P$. sylvestris. Results showed that precipitation is the main factor influencing tree growth and its fluctuation determines IADFs occurrence on the three pine species, with $P$. pinaster being the species that had the highest correlation values. Wet periods during winter previous to the growth season and spring induced higher growth rates for $P$. halepensis and $P$. pinaster, while the growth of $P$. sylvestris was mostly influenced by summer precipitation. However, the influence of these climatic variables on the growth of these species changed along the studied period, showing an increase in climate sensitivity at the end of the 20th century. Intra-annual growth of P. halepensis is mainly controlled by soil water availability during the growing season. However, relative extractable water in the soil influenced the stem radial increment in a crown classdependent way. Both crown classes experienced a significant growth release at the most intense thinning treatments. The negative effect of precipitation on wood density is consistent with its positive effect on radial growth. Despite the increasing climate
\end{abstract}


sensitivity of pine species during the most recent years, the trends in growth and mean density did not change in a 5-year interval. The results of these studies demonstrate that the inclusion of wood density and IADFs detection in chronologies adds new information to ring-width chronologies improving its quality. Besides, they help understanding the effects of stand structure on climate sensitivity and the differential effects of altering stand structure on climate-growth relationships of Mediterranean forest trees, both of which may assist managers promoting forests that are resilient to future climatic conditions. 


\section{RESUMEN}

Entender las relaciones entre el clima y el crecimiento es un aspecto clave para generar estrategias de mitigación del impacto del cambio climático. Durante la segunda mitad del siglo $\mathrm{XX}$, la región mediterránea ha experimentado un aumento de la temperatura media anual, un descenso de las precipitaciones y un aumento en la frecuencia de los episodios de sequía. Sin embargo, en la parte oeste de la región mediterránea, las precipitaciones durante el invierno y la primavera han aumentado y las precipitaciones durante el verano han disminuido. Se aplicaton técnicas dendrocronológicas en 28 sitios de muestreo situados en España para analizar larelación entre el crecimiento de Pinus halepensis (8 sitios de muestreo) P. pinaster (9 sitios de muestreo) y P. sylvestris (11 sitios de muestreo) y las variables climáticas en ambientes mediterráneos. Los objetivos de la presente tesis son: a) identificar y comparar las relaciones entre el crecimiento inter-anual y el clima a lo largo del tiempo de $P$. halepensis, $P$. pinaster y $P$. sylvestris en España, b) cuantificar y comparar la presencia de fluctuaciones intra-anuales de densidad (IADFs) en las tres especies y definir las variables climáticas asociadas a su presencia, c) identificar las variables climáticas que regulan el crecimiento intra-anual de $P$. halepensis, d) analizar el efecto del estrés hídrico en las diferentes clases de copa, e) investigar si la reducción de la densidad de la masa por medio de claras disminuye la vulnerabilidad de los árboles al estrés hídrico, f) establecer las relaciones entre el clima y la densidad de la madera en $P$. halepensis, $P$. pinaster y $P$. sylvestris. Los resultados muestran que las precipitaciones son el factor más determinante en el crecimiento y el la aparición de IADFs en las tres especies, siendo $P$. pinaster la que muestra las correlaciones más altas. Las precipitaciones durante el invierno previo y la primavera fueron las que afectaron en mayor medida al crecimiento de $P$. halepensis y $P$. pinaster, mientras que el crecimiento de $P$. sylvestris se vio principalmente influido por las precipitaciones en verano. Sin embargo, la influencia de esas variables climáticas en el crecimiento de las tres especies ha variado a lo largo del tiempo, mostrando un aumento de la sensibilidad climática a finales del siglo XX. El crecimiento intra-anual de $P$. halepensis está fundamentalmente controlado por la disponibilidad de agua en el suelo durante el periodo vegetativo. Sin embargo, el agua relativa extraíble del suelo influyó de distinta manera en el crecimiento radial de las distintas clases de copa. Ambas clases de 
copa experimentaron un aumento significativo del crecimiento radial tras los tratamientos de clara más intensos. El efecto negativo de las precipitaciones en la densidad de la madera concuerda con su efecto positivo en el crecimiento radial. A pesar del aumento de la sensibilidad climática de los pinos en los últimos años, las tendencias del crecimiento y la densidad media de la madera no cambian en un intervalo de 5 años. Estos resultados demuestran que la inclusión de IADFs en las cronologías añade nueva información mejorando su calidad y enfatizan el impacto de los tratamientos selvícolas en las relaciones entre el clima y el crecimiento. Además, ayudan a enteder los efectos de estructura del rodal en la sensibilidad climática y los efectos de sus cambios en las relaciones clima-crecimiento en los bosques mediterráneos, los cuales promueven bosques con mayor capacidad de resiliencia ante futuras condiciones climáticas. 

Olivar (2013) 


\section{ACKNOWLEDGEMENTS}

I would like to express my deep gratitude to everyone who stood by my side all these years:

Firstly, I would like to thank my supervisor Felipe Bravo for his valuable and constructive suggestions during the planning and development of this research work. His willingness to give his time so generously, the most precious asset at our institute, has been very much appreciated. My grateful thanks are also extended to Heinrich Spiecker for his support, guidance and useful critiques of this research work.

To my family for their endless love and support everytime and everywere. To my relatives for all these great "vermut" on Sundays.

To new and old friends, for being always ready to go for a beer or pick the guitars and organize a party at a wine cellar, terrace or anywhere.

To all my University colleagues for sharing so many hours in such a good mood. I would like to thank the following companies for their assistance with the collection of my data: Antonio Urchaga, Carlos del Peso, Cristina Prieto, Cristóbal Ordoñez, Encarna García, Irene Ruano, Javier Castaño, Lucía Risio, Luis Fernando Osorio, María Menéndez, Stella Bogino, Vivien Bonnesoeur and Wilson Lara.

To Celia Redondo for her support getting all necessary information and documentation everytime I needed.

To the Spanish Research National Projects AGL-2007-65795-C02-01 and AGL201129701-C02-02, the COST-Action FP0703 "Expected Climate Change and Options for European Silviculture" (ECHOES), and the scholarship program of the University of Valladolid for their financial support for field trips, assistance to courses and congresses and stays abroad.

To the Spanish Meteorological Agency (AEMET) and InfoRiego for providing the meteorological data, and María José Fernández Nieto for her assistance in getting them.

To all responsible people of my internships and stays abroad: Heinrich Spiecker from the 
University of Freiburg (Germany), Stella Bogino from the University of San Luis (Argentina) and Cyrille Rathgeber from INRA Nancy (France) for their warm welcome and to everybody who made these stays more pleasant.

To the co-authors of the manuscripts: Stella Bogino, Felipe Bravo, Heinrich Spiecker, Cyrille Rathgeber, Cristóbal Ordoñez and Vivien Bonnesoeur for their time and their useful and constructive comments.

To the LERFoB members for welcoming and supporting me at this final stage of the thesis. Merci a tous!

To the artists Laura, Marimar y Michal for contributing with their drawings to the final edition of the thesis.

To Sandra for her love and support, her dancing and cooking lessons. And to Benito, my companion during the thesis writing. 


\section{AGRADECIMIENTOS}

Quería expresar mi más sincero agradecimiento a todas esas personas que han estado a mi lado durante estos años:

A mi director Felipe Bravo por su apoyo permanente durante la realización de la tesis, sus correcciones, sus consejos y, sobre todo, por su tiempo, un bien muy preciado en el departamento. También me gustaría agradecerle a Heinrich Spiecker, su ayuda y sus inestimables comentarios realizados a los trabajos que forman parte de esta tesis.

A mi familia por su cariño y apoyo constante en todo momento y en todo lugar. A mis tíos y primos por esos vermut domingueros.

A los amigos de siempre y a los nuevos, por estar siempre dispuestos para tomar unas cañas o coger las guitarras y organizar una fiesta en una bodega, terraza o donde sea.

A los compañeros de la Universidad por compartir tantas horas con tan buen ambiente, en especial a todos aquellos que me ayudaron en los trabajos de campo, toma de muestras e instalación de dendrómetros: Antonio Urchaga, Carlos del Peso, Cristina Prieto, Cristóbal Ordoñez, Encarna García, Irene Ruano, Javier Castaño, Lucía Risio, Luis Fernando Osorio, María Menéndez, Stella Bogino, Vivien Bonnesoeur y Wilson Lara.

A Celia Redondo por su ayuda con la documentación, siempre que la he necesitado.

A las a los Proyectos del Plan Nacional Español de I+D AGL-2007-65795-C02-01 y AGL2011-29701-C02-02, a la COST-Action FP0703 "Expected Climate Change and Options for European Silviculture" (ECHOES) y al programa de becas de la Universidad de Valladolid por su ayuda financiera tanto en la obtención de muestras como en las estancias en el extranjero.

A la Agencia Española de Meteorología e InfoRioego por haberme proporcionado los datos climáticos y a María José Fernández Nieto por ayudarme a conseguirlos.

A los responsables de mis estancias en el extranjero: Heinrich Spiecker de la Universidad de Freiburg (Alemania), Stella Bogino de la Universidad Nacional de San Luis (Argentina) 
y Cyrille Rathgeber del INRA de Nancy (Francia) por su buena acogida y a todos aquellos que hicieron que las estancias fueran más agradables.

A los coautores de los artículos: Stella Bogino, Felipe Bravo, Heinrich Spiecker, Cyrille Rathgeber, Cristóbal Ordoñez, Vivien Bonnesoeur por su tiempo y sus útiles comentarios.

A los miembros del LERFoB de Nancy por acogerme y ayudarme durante esta última etapa de la tesis. Merci a tous!

A los artistas Laura, Marimar y Michal por aportar sus dibujos a la edición final de la tesis.

A Sandra por su amor y su apoyo, sus clases de baile y de cocina. Y a Benito, mi compañero durante la redacción de la tésis. 


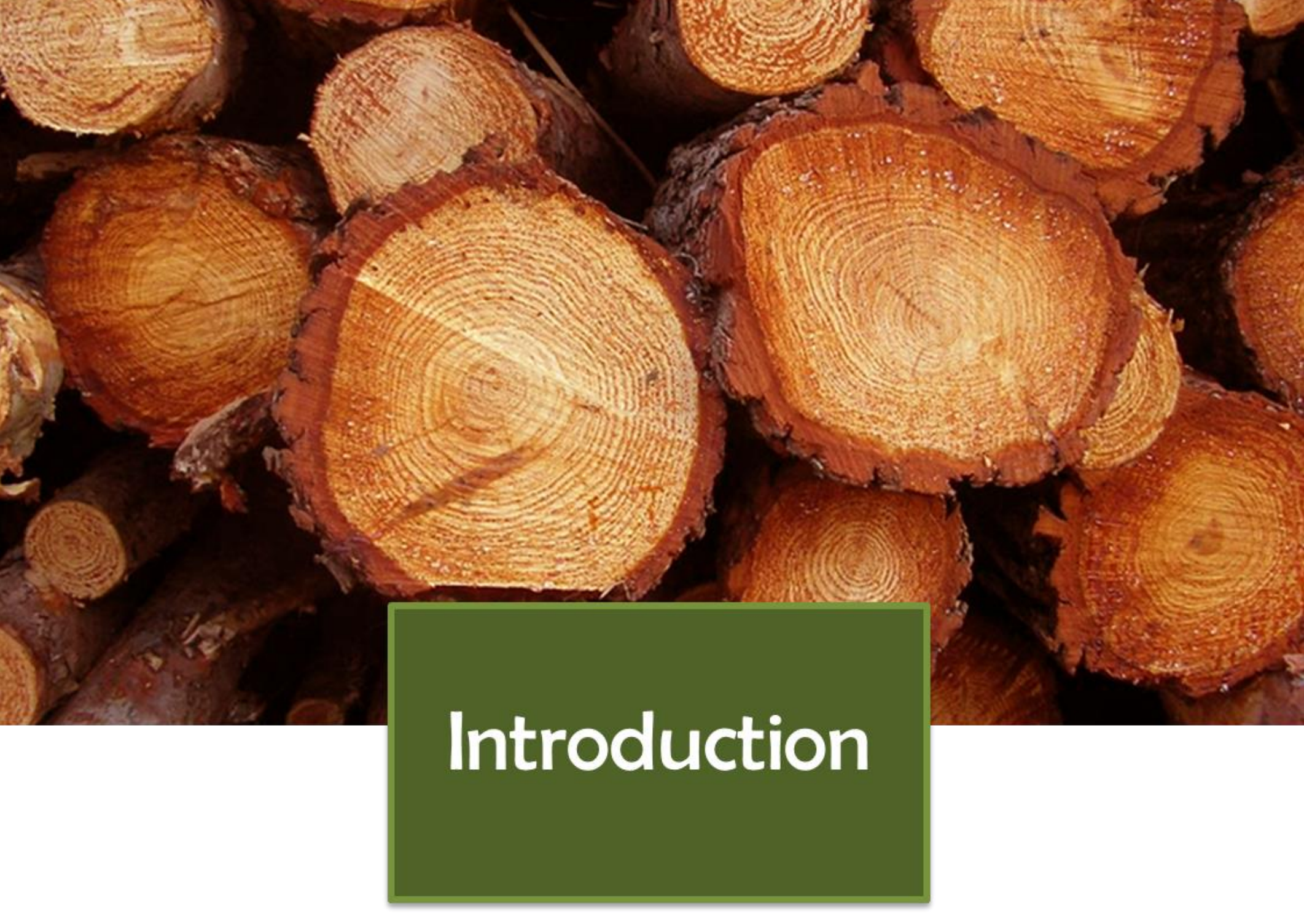


Olivar (2013) 


\section{INTRODUCTION}

\subsection{Mediterranean environments and climate change}

Mediterranean regions, as transitional climate zones between arid and humid regions of the world, are especially interesting for the study of the relationships between climate, tree growth and wood anatomic features. In the Mediterranean region, where rainfall is a major limiting factor for organisms, precipitation has decreased by about $30 \%$ during the last century (Petit et al., 2005). Annual temperatures over Europe have increased about $0.8{ }^{\circ} \mathrm{C}$ during the 20th century. A larger warming has been observed over the Iberian Peninsula (Houghton et al., 2001), where the 1980-1995 period was characterized by intense droughts, which produced severe damage to several woody species (Peñuelas et al., 2001).

Climate models project rising air temperatures and a decrease in annual mean precipitation over the Mediterranean Basin for the twenty-first century leading to an increase in evapotranspiration (Parry et al., 2007). Although the predicted warming trends are higher in northern and central Europe than in southern Europe (Klein Tank and Können, 2003), most of Europe will have a rather positive water balance, while precipitation in the countries surrounding the Mediterranean Sea are expected to experience the largest decrease on the globe, more than $20 \%$. Therefore, the Mediterranean area is considered to be one of the areas where climatic changes may have the greatest effects (Lavorel et al., 1998). Given the magnitude of forecasted trends, there are great concerns for the particularly rich biodiversity found in the region. Studies on the consequences of past climate shifts on biodiversity represent one of the best sources of data to validate models of the ecological and evolutionary consequences of future changes (Petit et al., 2005).

Precipitation is the main factor influencing tree growth of pine species in semiarid Mediterranean conditions (Raventós et al., 2001). In coastal Mediterranean areas, with mild winters and dry summers, cold season growth dormancy may not occur and, consequently, cambial activity is likely continuous (de Luis et al., 2007). However, in inland areas with continental Mediterranean climate, plants endure double climatic stress, caused by low winter temperatures and summer drought (Mitrakos, 1980). As a result, optimal growth 
conditions are split into two mild periods with increased rainfall (spring and autumn), which suggest a bimodal pattern of cambial activity (Camarero et al., 2010).

Trees of different sizes and crown classes compete differently for light, water and other resources within a stand ( Peet and Christensen, 1987; Orwig and Abrams, 1997). Radial growth responses to climate vary considerably according to local tree density and crown class in areas where water is limiting (Linares et al., 2009; Martín-Benito et al., 2008). Therefore, contrasting growth responses to climate among trees of different crown classes might be particularly relevant for understanding the dynamics of forests dominated by species that are highly sensitive to drought stress (Adams and Kolb, 2004).

\subsection{Species studied}

\subsubsection{Aleppo pine (Pinus halepensis Mill.)}

Aleppo pine (Pinus halepensis) is one of the most studied Mediterranean species. It plays an important role in the ecology and landscape of the Mediterranean basin. Stands of this species provide a valuable system to explore how growth measured at different time scales is constrained by climate (Pasho et al., 2012). It is considered as a species well adapted to drought by reducing growth as water availability decreases (Rathgeber et al., 2005; de Luis et al., 2007; Camarero et al., 2010).

It is generally found at low elevations, mostly from sea level to 200 metres, but it can grow at an altitude of up to $1000 \mathrm{~m}$ in southern Spain. This pioneer and undemanding species is easily regenerated and capable of colonizing very poor and degraded soils. It is an essential component in reforestation strategy for limy soils in the arid or semi-arid climates of the Mediterranean basin, due both to its intrinsic ability to colonize and to its effect in improving soils and microclimates, thus in turn favouring the growth of broadleaved Mediterranean species (Quercus ilex L., Q. coccifera L. and Q. faginea Lamk.) within its stands (Quezel, 1986). In Spain, P. halepensis occupies 1 million ha in monospecific stands, and 0.5 million ha in mixed stands, of which 0.2 million ha are with Pinus nigra Arn. ssp. salzmanii, 183,184 ha with P. pinaster Ait. and 84,847 ha with Quercus ilex (Montero et al., 2001) (Fig. 1a). 


\subsubsection{Maritime pine (Pinus pinaster Ait.)}

Maritime pine (Pinus pinaster) is a characteristic species in Mediterranean forests, and is mainly located in the Iberian Peninsula (Blanco et al., 1997). This species shows a wide ecological range (Nicolás and Gandullo, 1967), and it can survive under high or low temperatures, under regular or variable rainfall as well as under severe droughts. It is adapted to the extremely cold winters of the continental climate in central Spain and to the mild, temperate winters of the Atlantic coast in the western Iberian Peninsula (Alía et al., 1996; Blanco et al., 1997).

In Spain, $P$. pinaster constitutes pure and mixed woodlands that are both natural (1 million ha) and planted (0.6 million ha) (DGCN, 2002). These woodlands are mainly spread over the northern Spanish plateau up to $1500 \mathrm{~m}$ in elevation. In this area, the climate is characterized by irregular between- and within-year rainfall, and high temperatures in summer. The soils are sandy and rocky and very well drained. Even though the maritime pine had been widely plantated in the Iberian Peninsula, this species grows naturally in some areas, where it is the best adapted woody species (Blanco et al., 1997). Fossil $P$. pinaster cones and pollen dating from the Superior Pliocene have been found in the Iberian Peninsula, suggesting a Pre-Mediterranean origin for this species and evolution in tropicallike environments that gradually incorporated seasonal aridity (Specht, 1981). Some authors suggest that the Iberian System is the natural origin of and centre of distribution for this species (Blanco et al., 1997) (Fig. 1b).

\subsubsection{Scots pine (Pinus sylvestris L.)}

Scots Pine (Pinus sylvestris) plays an important role in Spanish forestry because of its economic, ecological and social relevance. It is the most widely distributed species of pine in the world (Blanco et al., 1997); along with Norway spruce (Picea abies L.), it possesses the highest dendrochronological potential in Europe (Schweingruber, 1996). It grows in the cold continental climate of northern Asia as well as in the semiarid climate of southern Europe. Forests of $P$. sylvestris in Spain are ai its southern and western distribution threshold and occupy drier areas than in the other parts of the world (Barbéro et al., 1998). 
These dry areas of distribution of this species which usually grows in humid environments are the first places to investigate the effects of increased aridity (Martínez-Vilalta and Piñol, 2002). Besides, in assessing the impact of global warming on ecosystems, any changes in tree growth are likely to occur first in those tree stands located at the ecological boundary of the species (Tessier et al., 1997). In Spain, P. sylvestris stands occupy 1.2 million ha, split approximately in 50\% pure and 50\% mixed stands (DGCN, 2002) (Fig. 1c).
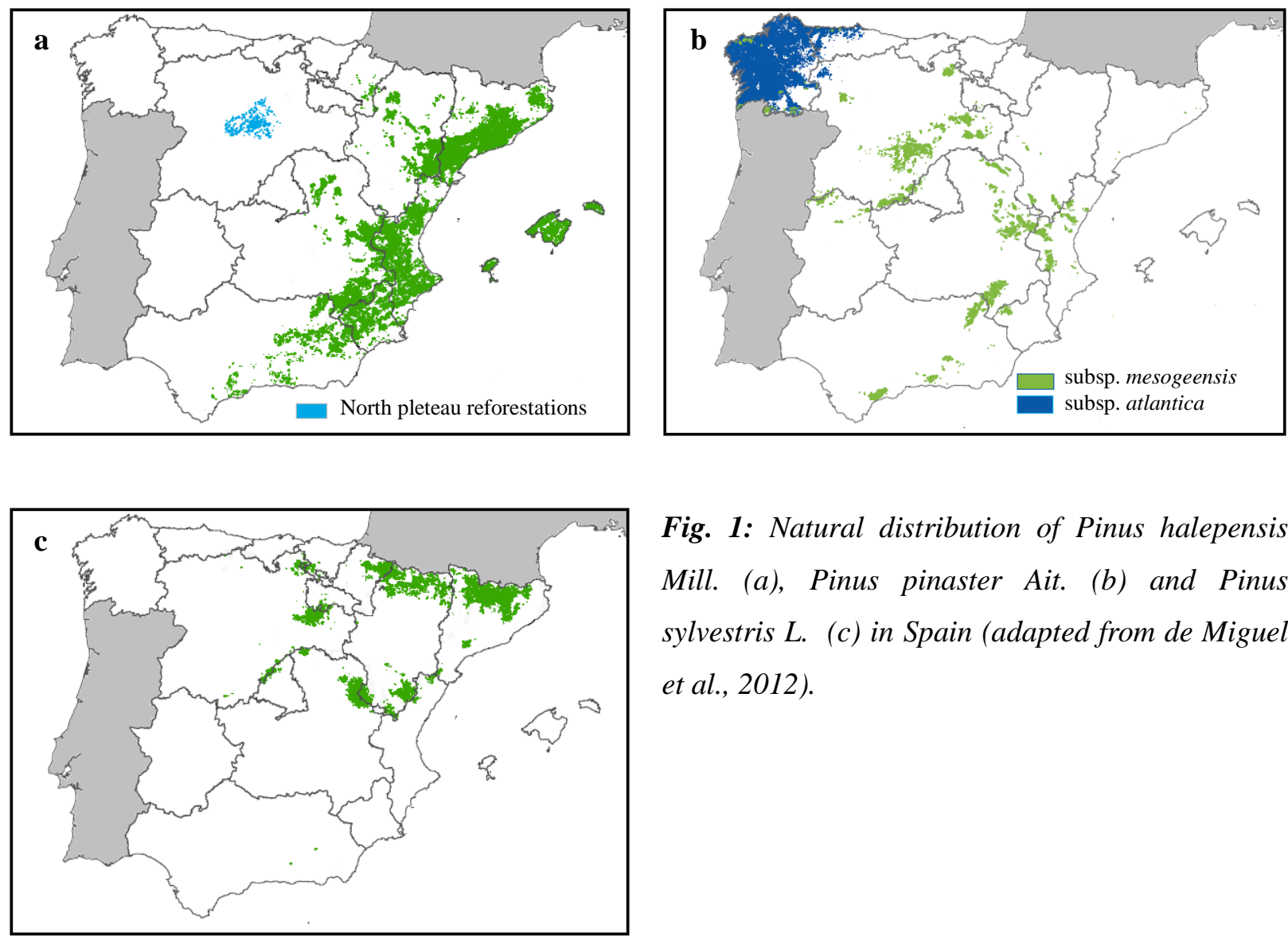

Fig. 1: Natural distribution of Pinus halepensis Mill. (a), Pinus pinaster Ait. (b) and Pinus sylvestris L. (c) in Spain (adapted from de Miguel et al., 2012).

\subsection{Growth-climate relationships}

Kaennel and Schweingruber (1995) definded dendroclimatology as the use of tree rings to study and reconstruct past and present climate. Dendroclimatology starts with site and tree selection and continues with dating, measuring, data quality control, and chronology construction. Tree rings are associated with climate using statistical models that are then evaluated for their full length to reconstruct climate of the past (Sheppard, 2010). 
Different methodological approaches can be used to explore tree growth-climate relationships, but dendroclimatological studies are valuable tools in detecting long term changes in radial growth in woody species related to climatic variable response as a result of warmer conditions and precipitation variability (Andreu et al., 2007).

Dendroclimatology generally assumes that climate-growth relationships are age and size independent. However, there is evidence that climate response can be unstable across different species, sites and age/size classes (Tardif et al., 2003; Campelo et al., 2013). Climate change is resulting in both positive and negative trends in tree growth, the latter frequently observed in drought-stressed environments (Camarero et al., 2010). The influence of climatic variables on growth can be modified along time (Andreu et al., 2007) and previous studies showed a changing association between climatic variables and growth of Pinus species on the Mediterranean area (Bogino and Bravo, 2008; Vieira et al., 2010; Campelo et al., 2013). Since the mid 20th century, an overall increase of the mean annual temperature, a decrease of the annual precipitation and a higher frequency of severe drought periods have been observed in the Mediterranean area (Martrat et al., 2004; Xoplaki et al., 2006). However, in the western Mediterranean regions, winter and spring precipitation increased and summer precipitation decreased during that period (Bradley et al., 1987; Maheras, 1988; Diaz et al., 1989). Although temperature and precipitation have changed over the last 50 years, it is not clear yet how trees respond to these changes, how these responses vary along time and which anatomical structures, if any, can be used to document tree response to climate change (Vieira et al., 2010).

\subsection{Intra-annual density fluctuations (IADFs)}

Pine species have a typical conifer wood structure, containing resin canals and clearly distinguishable tree rings with earlywood (EW) and latewood (LW), and a more or less gradual transition between them (Schweingruber, 1993). Wood anatomical features in tree rings have been interpreted as indicators of environmental change (Briffa et al., 2004). However, species growing under Mediterranean climate, with summer droughts and high inter-annual variability in precipitation and temperature, commonly show deviations from such normal structure characterized by abrupt changes in ring width, variable frequency of normal and of traumatic resin canals, and intra annual density fluctuations (IADFs) (de 
Luis et al., 2007).

IADFs are defined as "a layer of cells within a tree ring identified by different shape, size and wall thickness" (Kaennel and Schweingruber, 1995). IADFs are easily distinguishable from annual tree ring boundaries by the gradual transition in cell size and wall thickness at the outer borders of these anatomical structures. IADFs are identified by considering the position of the density fluctuation within the ring (Campelo et al., 2007). The IADF type E are characterized by latewood-like cells within earlywood, whereas the IADF type L are considered when earlywood-like cells are within the latewood (study II, Fig. 3).

The inclusion of IADFs in dendrochronological studies allows detailed analysis of climatic events within a particular growing season. Different studies of pine species showed a good correlation between IADF formation and climate in the Mediterranean area. IADFs were mainly correlated with precipitation in autumn in P. pinaster in Portugal (Vieira et al., 2009) and with precipitation in late winter and spring and higher temperatures in central Spain (Bogino and Bravo, 2009). IADFs were caused by precipitation events early in summer following a water deficit early in the growing season in $P$. pinea in southern Portugal (Campelo et al., 2007).

The consistency of the climatic signal among different pine species and areas suggests that, in the future, a large-scale network of IADFs could be developed in the Mediterranean region to study intra-annual climate variability (Campelo et al., 2013). The analysis of the occurrence of inter-annual density fluctuations and the stabilized IADF frequency in relation to calendar year allows a more detailed analysis of climatic events within affecting tree rings in the growing season. 


\subsection{Effects of thinning on growth dynamics and growth-climate relationships}

The changing demands of today require a widened scope of forest management. Society is asking for sustainable forestry emphasizing biodiversity and naturalistic forest management. It is of great economic and ecological relevance to know on which sites today's forests are most susceptible to climatic and other environmental changes and hazards (Spiecker, 2003).

The response of tree growth to limiting factors can be influenced by silviculture. The effect of different silvicultural scenarios and stand densities on tree growth response to climate is likely to be a key factor for forest preservation, particularly on the driest sites (GeaIzquierdo et al., 2009). The influence of tree density on their response to climate and drought is not a straightforward issue, since different approaches (e.g. ecophysiological, dendroecological, growth modelling) might give different insights (Misson et al., 2003; Moreno and Cubera, 2008). However, increasing resistance of forests will increase economic and social benefits of forests and reduce the risks by maintaining sustainable forestry (Spiecker, 2003).

Thinning experiment sites are the best option to determine adequate thinning alternatives and density targets. However, stand densities can occur in an almost infinite array of combinations, and as a result, it is unreasonable to expect that all possible combinations could be test in field experiment before apply it in operational forestry (Valbuena and Bravo, 2008). Data on growth dynamics is required to understand growth responses in relation to climatic variability at short time scales, the delayed growth responses to climate and the water budget which may not be detected by coarser assessments based on response functions (Gutiérrez et al., 2011). Dendrometers (Fig. 2) are a valuable tool for these studies since they provide short-term non-destructive measurements of radial fluctuations in relation to climate without disturbing the cambium. 


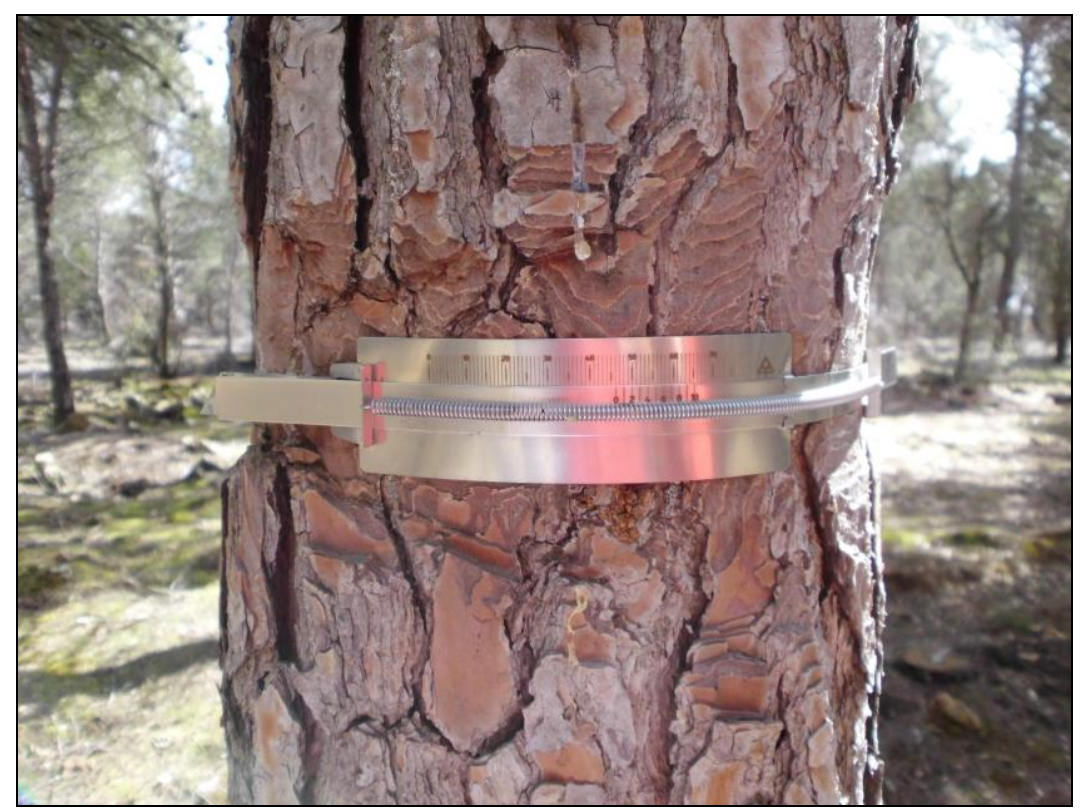

Fig. 2: Stainless-steel band dendrometer (Dendrometer Increment Sensor DB20 EMS Brno).

\subsection{Climate impact on wood density}

Changes in forest productivity in Europe indicate that forest growth has altered considerably during the past decades (Spiecker et al., 1996). Future changes in climate could affect not only tree growth, but also tree-ring structure. Wood density is especially important as it is correlated with various physical, chemical, and anatomical features of the wood and thus yields basic information concerning problems of wood technology, forestry and climatology. Tree-rings are regularly composed of earlywood, in which tracheids have relatively large diameters and thin cell walls and latewood, with small tracheids having thick cell walls. Severe conditions during the growing season, such as water stress, may generate the production of latewood-like cells within earlywood or earlywood-like cells within latewood varying density patterns (Schweingruber et al., 1978; Fritts, 2001).

Previous dendroclimatic studies have shown that wood density is highly sensitive to climate variations at the inter-annual time scale ( Parker and Henoch, 1971; Schweingruber et al., 1978; Conkey, 1979; Briffa et al., 2001; Roderick and Berry, 2001; Bouriaud et al., 2005) and intra-annual time scale (Sass and Eckstein, 1995; Horacek et al., 1999; Schmitt et al., 2000; Mäkinen et al., 2003; Bouriaud et al., 2005; Büntgen et al., 2010; van der Maaten et al., 2012), but little is known about intra-annual density-climate relationships in 
the Mediterranean, where the cambial activity can vary from year to year presenting continuous radial growth or one or two growth interruptions in line with the variability of climatic conditions (de Luis et al., 2007). Previous studies in Spain concluded that the growth of $P$. halepensis and $P$. pinaster was influenced by wet periods during winter

previous to the growth season and spring, while the growth of $P$. sylvestris was mostly influenced by summer precipitation (Bogino and Bravo, 2008; Bogino et al., 2009; Olivar et al., 2012). However, there were no previous detailed studies on the impact of climate on wood density in these species.

\subsection{Objectives}

This thesis has a main objective: to explore the impact of climate on pine trees growing in Mediterranean conditions. This general objective assess through the following specific objectives.

\subsubsection{Climate impact on growth dynamic and intra-annual density fluctuations in Aleppo pine (Pinus halepensis) trees of different crown classes: Study I}

The knowledge of the growth response of $P$. halepensis to past climate variability can help us to explore how its populations, and the ecosystems they dominate, will behave in the future. Besides reflecting changes in the environmental conditions during the growing season, the inclusion of IADFs detection in chronologies adds new information to ringwidth chronologies improving its quality and allows detailed analysis of climatic events within the growing season. The specific objectives of this study were: i) to identify the relationships between radial growth and regional climate for different crown classes of $P$. halepensis, ii) to quantify the presence of intra-annual density fluctuations (IADFs) according to crown class and cambial age and iii) to analyse the relationships between IADFs occurrence and climate. 
1.7.2. Changes in climate-growth relationships and IADF formation over time in Mediterranean pine species (Pinus halepensis, P. pinaster and P. sylvestris) in Spain: Study II

The analysis of the responses of Mediterranean pine species to climate change and which anatomical structures can be used to document it will help understand future trends in climate-growth relationships. The specific objectives of this study were: i) to identify and compare radial growth-climate relationships along time for $P$. halepensis, $P$. pinaster and $P$. sylvestris in Spain ii) to quantify and compare the presence of intra-annual density fluctuations (IADFs) on the three species and iii) to define the climatic variables that are associated with the occurrence of IADFs.

\subsubsection{Effects of thinning on growth dynamics and growth-climate relationships in} Aleppo pine (Pinus halepensis) trees of different crown classes: Study III

Silvicultural practices have an impact on growth-climate relationships. Since a warming trend and a precipitation decline have been predicted for the forthcoming decades, this may have a significant importance on future forest dynamics in Iberian pine forests at a regional scale. The specific objetives of this study were: i) to identify the main climatic driver of intra-annual growth of $P$. halepensis in our site, representing semi-arid Mediterranean environments ii) to analyse which crown class is more affected by water stress and iii) to investigate if the reduction of stand density through thinning decreases its vulnerability to water stress. 


\subsubsection{Climate impact on wood density in Pinus halepensis, Pinus pinaster and Pinus} sylvestris: Study IV

The study of wood formation and its dependence on climatic conditions is of major interest because tree physiological processes, wood density and wood properties are interrelated. The specific objectives of this study were: i) to identify the main climatic drivers of radial growth and density patterns for $P$. halepensis, $P$. pinaster and $P$. sylvestris; and ii) to analyse the relationships between tree-ring width and wood density in the three species. 
Olivar (2013) 
$\left.35 x^{2} \times 4\right)$

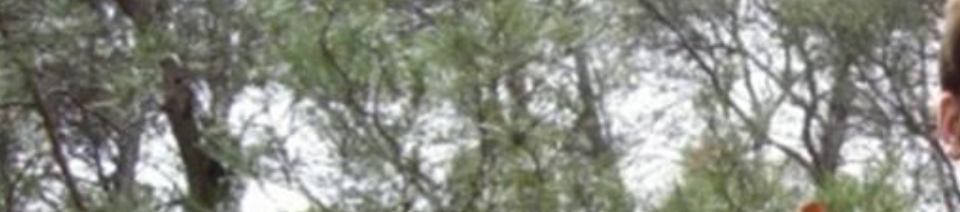

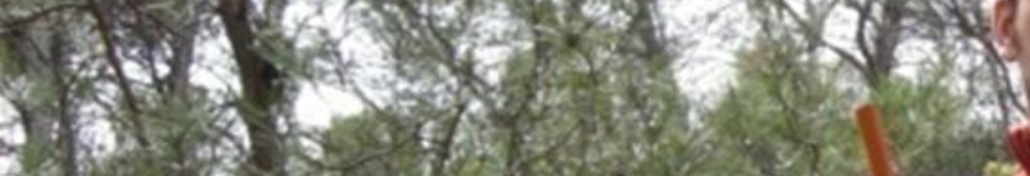
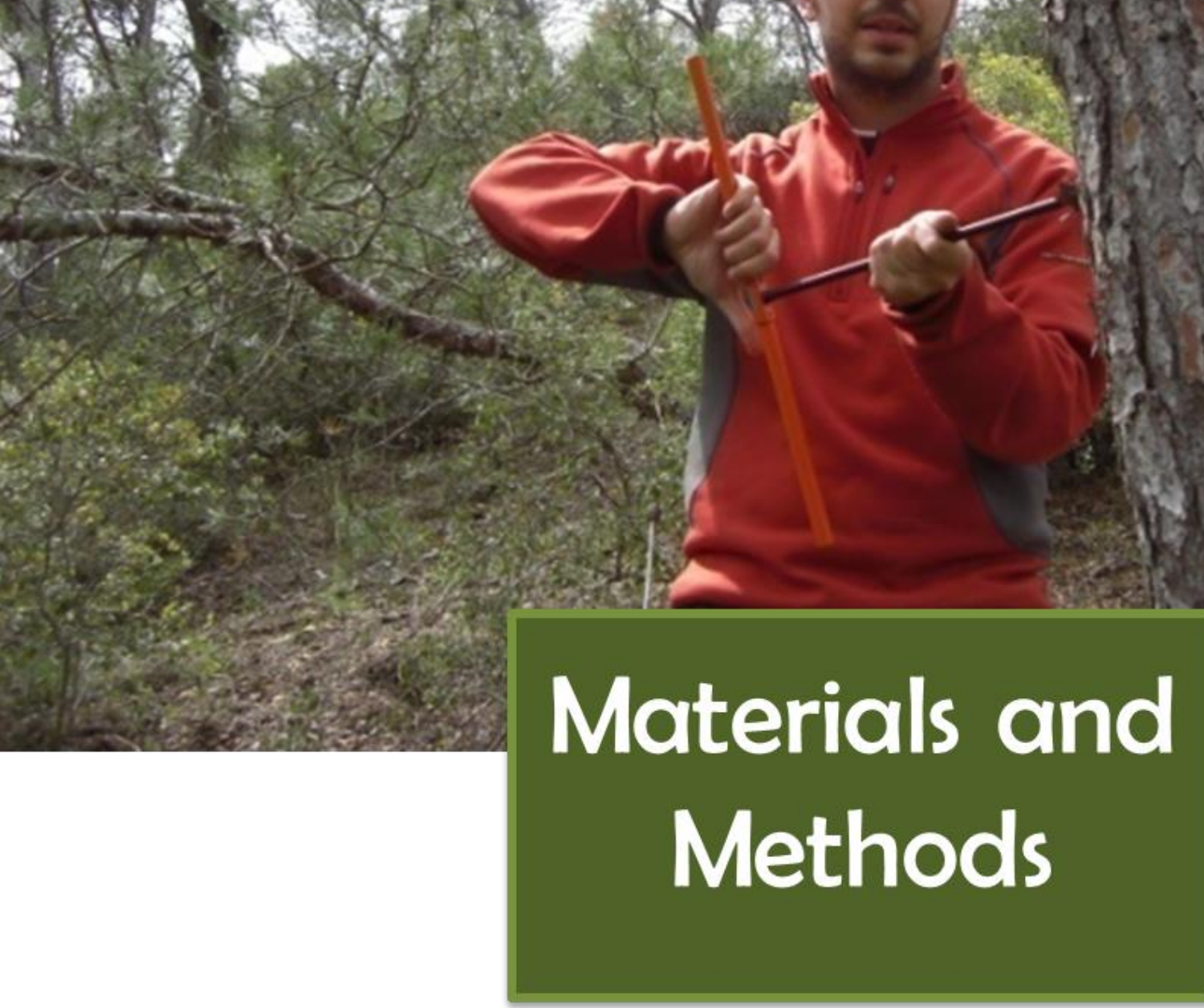
Olivar (2013) 


\section{MATERIALS AND METHODS}

\subsection{Study sites}

In order to achieve the general and specific objectives of each study, 28 study areas (8P. halepensis sites, 9 P. pinaster sites and 11 P. sylvestris sites) were selected in Spain (Fig. 3, Table 1).

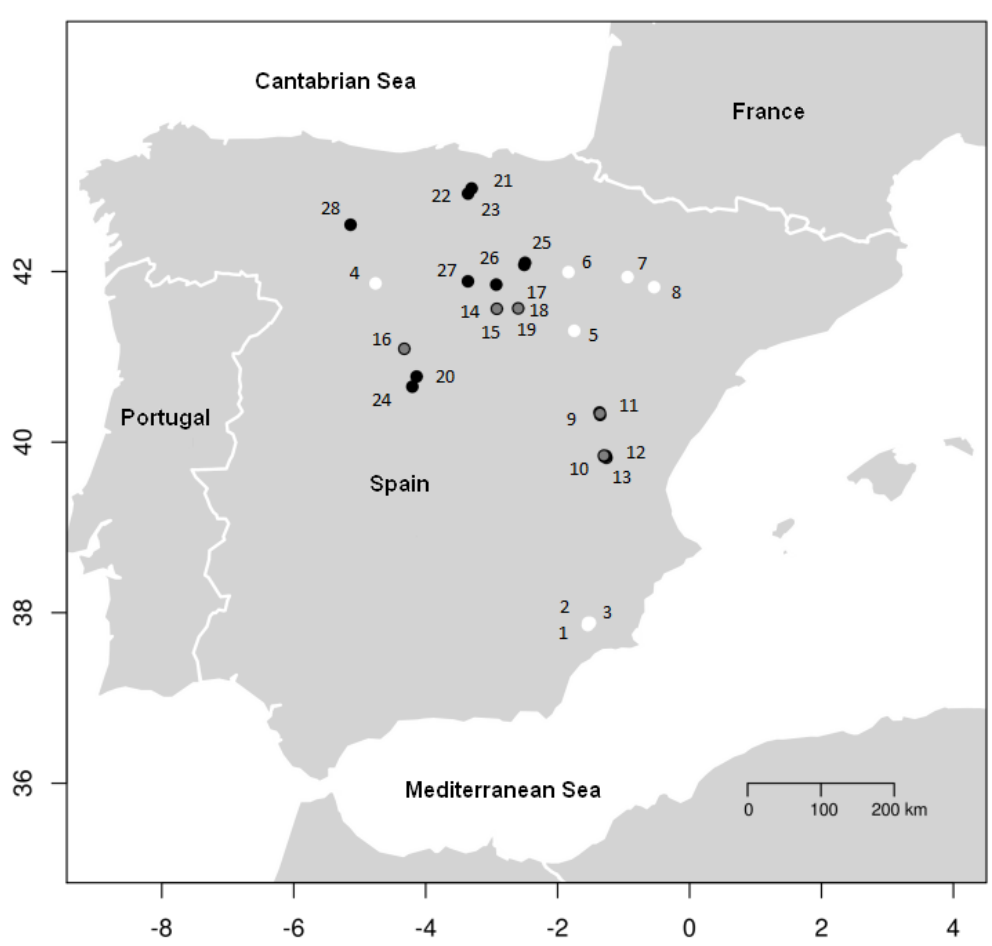

Fig. 3: Study areas of the three pine species in Spain. White: P. halepensis; grey: P. pinaster; black: P. sylvestris.

In study I, we analysed increment cores from 8 P. halepensis sites (tags 1 to 8 in Fig. 3). Fifteen dominant and fifteen suppressed trees were selected in each site. In study II, we analysed increment cores from 8 P. halepensis sites (tags 1 to 8 in Fig. 3), 10 P. pinaster sites (tags 9 to 15 and 17 to 19 in Fig. 3) and 8 P. sylvestris sites (tags 20 to 23 and 25 to 28 in Fig. 3). Fifteen dominant trees were selected on each site. In study III, a thinning experiment was developed in a $P$. halepensis study site (tag 4 in Fig. 3), where 48 trees were selected ( 6 dominant and 6 suppressed trees in each of the 4 thinning treatments). 
Olivar (2013)

Table 1: Sampling sites description of P. halepensis, P. pinaster and P. sylvestris in Spain. Precp: Annual precipitation; Temp: Mean annual temperature.

\begin{tabular}{|c|c|c|c|c|c|c|c|c|}
\hline Species & Number & Location & $\begin{array}{l}\text { Latitude } \\
\text { (N) }\end{array}$ & $\begin{array}{l}\text { Longitude } \\
\text { (W) }\end{array}$ & $\begin{array}{l}\text { Altitude } \\
\text { (m) }\end{array}$ & Time span & $\begin{array}{c}\text { Precip. } \\
\text { (mm) }\end{array}$ & $\begin{array}{c}\text { Temp. } \\
\left({ }^{\circ} \mathrm{C}\right)\end{array}$ \\
\hline \multirow[t]{8}{*}{ P. halepensis } & 1 & Murcia & $37^{\circ} 52^{\prime} 51^{\prime \prime}$ & $1^{\circ} 30^{\prime} 36^{\prime \prime}$ & 811 & $1932-2008$ & 617 & 12.7 \\
\hline & 2 & Murcia & $37^{\circ} 52^{\prime} 50^{\prime \prime}$ & $1^{\circ} 32^{\prime} 15^{\prime \prime}$ & 957 & $1915-2008$ & 617 & 12.7 \\
\hline & 3 & Murcia & $37^{\circ} 51^{\prime} 13^{\prime \prime}$ & $1^{\circ} 32^{\prime} 34^{\prime \prime}$ & 1118 & 1914-2008 & 617 & 12.7 \\
\hline & 4 & Palencia & $41^{\circ} 51^{\prime} 36^{\prime \prime}$ & $4^{\circ} 45^{\prime} 36^{\prime \prime}$ & 849 & $1975-2008$ & 441 & 12.1 \\
\hline & 5 & Zaragoza & $41^{\circ} 18^{\prime} 16^{\prime \prime}$ & $1^{\circ} 44^{\prime} 52^{\prime \prime}$ & 976 & $1978-2008$ & 344 & 12.3 \\
\hline & 6 & Zaragoza & $41^{\circ} 59^{\prime} 31^{\prime \prime}$ & $1^{\circ} 50^{\prime} 09^{\prime \prime}$ & 695 & $1975-2008$ & 395 & 13.1 \\
\hline & 7 & Zaragoza & $41^{\circ} 48^{\prime} 58^{\prime \prime}$ & $0^{\circ} 32^{\prime} 15^{\prime \prime}$ & 535 & 1919-2007 & 616 & 12.4 \\
\hline & 8 & Zaragoza & $41^{\circ} 56^{\prime} 04^{\prime \prime}$ & $0^{\circ} 56^{\prime} 25^{\prime \prime}$ & 706 & $1926-2007$ & 587 & 12.4 \\
\hline \multirow[t]{11}{*}{ P. pinaster } & 9 & Cuenca & $39^{\circ} 50^{\prime} 17^{\prime \prime}$ & $1^{\circ} 16^{\prime} 11^{\prime \prime}$ & 970 & $1880-2005$ & 901 & 8.3 \\
\hline & 10 & Cuenca & $39^{\circ} 48^{\prime} 56^{\prime \prime}$ & $1^{\circ} 15^{\prime} 36^{\prime \prime}$ & 920 & $1948-2005$ & 901 & 8.3 \\
\hline & 11 & Cuenca & $39^{\circ} 50^{\prime} 06^{\prime \prime}$ & $1^{\circ} 16^{\prime} 37^{\prime \prime}$ & 1078 & $1948-2005$ & 901 & 8.3 \\
\hline & 12 & Cuenca & $39^{\circ} 49^{\prime} 48^{\prime \prime}$ & $1^{\circ} 17^{\prime} 38^{\prime \prime}$ & 1010 & $1978-2005$ & 901 & 8.3 \\
\hline & 13 & Cuenca & $39^{\circ} 50^{\prime} 28^{\prime \prime}$ & $1^{\circ} 17^{\prime} 54^{\prime \prime}$ & 1090 & $1887-2005$ & 901 & 8.3 \\
\hline & 14 & Soria & $41^{\circ} 34^{\prime} 03^{\prime \prime}$ & $2^{\circ} 35^{\prime} 51^{\prime \prime}$ & 1059 & $1918-2005$ & 487 & 8.3 \\
\hline & 15 & Soria & $41^{\circ} 33^{\prime} 43^{\prime \prime}$ & $2^{\circ} 55^{\prime} 17^{\prime \prime}$ & 1012 & $1948-2005$ & 484 & 10.2 \\
\hline & 16 & Segovia & $41^{\circ} 23^{\prime} 47^{\prime \prime}$ & $4^{\circ} 28^{\prime} 17^{\prime \prime}$ & 753 & $1939-2012$ & 465 & 11.2 \\
\hline & 17 & Teruel & $40^{\circ} 19^{\prime} 07^{\prime \prime}$ & $1^{\circ} 21^{\prime} 18^{\prime \prime}$ & 1437 & $1846-2005$ & 563 & 10.4 \\
\hline & 18 & Teruel & $40^{\circ} 20^{\prime} 47^{\prime \prime}$ & $1^{\circ} 21^{\prime} 54^{\prime \prime}$ & 1364 & 1849-2005 & 563 & 10.4 \\
\hline & 19 & Teruel & $40^{\circ} 20^{\prime} 01^{\prime \prime}$ & $1^{\circ} 21^{\prime} 26^{\prime \prime}$ & 1232 & $1953-2005$ & 563 & 10.4 \\
\hline \multirow[t]{9}{*}{ P. sylvestris } & 20 & Avila & $40^{\circ} 38^{\prime} 58^{\prime \prime}$ & $4^{\circ} 12^{\prime} 7^{\prime \prime}$ & 1438 & $1813-2005$ & 559 & 7.5 \\
\hline & 21 & Burgos & $42^{\circ} 58^{\prime} 22^{\prime \prime}$ & $3^{\circ} 18^{\prime} 12^{\prime \prime}$ & 888 & $1867-2005$ & 632 & 9.2 \\
\hline & 22 & Burgos & $41^{\circ} 53^{\prime} 4^{\prime \prime}$ & $3^{\circ} 21^{\prime} 32^{\prime \prime}$ & 1097 & $1848-2005$ & 487 & 10.2 \\
\hline & 23 & Burgos & $42^{\circ} 54^{\prime} 46^{\prime \prime}$ & $3^{\circ} 21^{\prime} 27^{\prime \prime}$ & 814 & $1935-2005$ & 527 & 10.3 \\
\hline & 24 & Segovia & $40^{\circ} 46^{\prime} 4^{\prime \prime}$ & $4^{\circ} 08^{\prime} 14^{\prime \prime}$ & 1440 & $1891-2005$ & 466 & 9.7 \\
\hline & 25 & Soria & $42^{\circ} 6^{\prime} 6^{\prime \prime}$ & $2^{\circ} 29^{\prime} 36^{\prime \prime}$ & 1165 & $1951-2005$ & 487 & 10.2 \\
\hline & 26 & Soria & $42^{\circ} 4^{\prime} 36^{\prime \prime}$ & $2^{\circ} 30^{\prime} 18^{\prime \prime}$ & 1431 & $1960-2005$ & 487 & 10.2 \\
\hline & 27 & Soria & $41^{\circ} 50^{\prime} 44^{\prime \prime}$ & $2^{\circ} 55^{\prime} 48^{\prime \prime}$ & 1659 & $1946-2005$ & 487 & 10.2 \\
\hline & 28 & León & $42^{\circ} 48^{\prime} 10^{\prime \prime}$ & $5^{\circ} 07^{\prime} 31^{\prime \prime}$ & 975 & 1989-2012 & 898 & 10.0 \\
\hline
\end{tabular}

In study IV, we analysed increment cores from one $P$. halepensis site (number 4), one $P$. 
pinaster site (number 16) and one $P$. sylvestris site (number 24).

Dominant trees were defined as those standing above all other trees in its vicinity and receiving full light from above, whereas suppressed trees were defined as those growing below the tree canopy. Two cores were extracted at $1.30 \mathrm{~m}$ above ground from each selected tree.

Mean monthly air temperatures and total monthly precipitations recorded at the closest meteorological stations were obtained from the "Agencia Estatal de Meteorología, Spain", while daily climatic variables (temperature, precipitation, air humidity, wind speed and radiation) were obtained from $w w w$.inforiego.org (Table 2).

Table 2: Description of the meteorological stations. Data provided by Agencia Estatal de Metereología (AEMet) and InfoRiego(IR).

\begin{tabular}{ccccccc}
\hline $\begin{array}{c}\text { Meteorological } \\
\text { Station }\end{array}$ & Time span & Location & $\begin{array}{c}\text { Latitude } \\
(\mathbf{N})\end{array}$ & $\begin{array}{c}\text { Longitude } \\
(\mathbf{W})\end{array}$ & $\begin{array}{c}\text { Altitude } \\
(\mathbf{m})\end{array}$ & Data \\
\hline Moratalla "Benizar" & $1934-2008$ & Murcia & $38^{\circ} 16^{\prime} 25^{\prime \prime}$ & $1^{\circ} 58^{\prime} 59^{\prime \prime}$ & 899 & AEMet \\
Palencia E.C.A. & $1974-2008$ & Palencia & $42^{\circ} 00^{\prime} 30^{\prime \prime}$ & $4^{\circ} 33^{\prime} 27^{\prime}$, & 740 & AEMet \\
Fuentes de Nava & $2008-2012$ & Palencia & $42^{\circ} 04^{\prime} 59^{\prime \prime}$ & $4^{\circ} 46^{\prime} 59^{\prime \prime}$ & 472 & IR \\
Calatayud aguas & $1975-2003$ & Zaragoza & $41^{\circ} 19^{\prime} 51^{\prime \prime}$ & $1^{\circ} 38^{\prime} 49^{\prime \prime}$ & 600 & AEMet \\
Tarazona & $1977-2008$ & Zaragoza & $41^{\circ} 54^{\prime} 28^{\prime \prime}$ & $1^{\circ} 43^{\prime} 54^{\prime \prime}$ & 475 & AEMet \\
Sos del Rey Católico & $1933-2007$ & Zaragoza & $42^{\circ} 29^{\prime} 34^{\prime \prime}$ & $1^{\circ} 12^{\prime} 52^{\prime \prime}$ & 630 & AEMet \\
Cuenca & $1956-2005$ & Cuenca & $40^{\circ} 04^{\prime} 35^{\prime \prime}$ & $2^{\circ} 07^{\prime} 53^{\prime \prime}$ & 956 & AEMet \\
El Burgo de Osma & $1932-2005$ & Soria & $41^{\circ} 35^{\prime} 08^{\prime \prime}$ & $3^{\circ} 04^{\prime} 17^{\prime \prime}$ & 895 & AEMet \\
Soria (Observatorio) & $1944-2005$ & Soria & $41^{\circ} 45^{\prime} 60^{\prime \prime}$ & $2^{\circ} 28^{\prime} 00^{\prime}$, & 1082 & AEMet \\
Villanubla & $1939-2011$ & Valladolid & $41^{\circ} 42^{\prime} 41^{\prime \prime}$ & $4^{\circ} 50^{\prime} 41^{\prime \prime}$ & 846 & AEMet \\
Pantano de la Toba & $1944-2005$ & Teruel & $40^{\circ} 12^{\prime} 60^{\prime \prime}$ & $1^{\circ} 55^{\prime} 60^{\prime \prime}$ & 900 & AEMet \\
Aldea del Rey Niño & $1935-2005$ & Ávila & $40^{\circ} 34^{\prime} 60^{\prime \prime}$ & $4^{\circ} 44^{\prime} 60^{\prime \prime}$ & 1160 & AEMet \\
Miranda de Ebro & $1936-2005$ & Burgos & $42^{\circ} 40^{\prime} 49^{\prime \prime}$ & $2^{\circ} 57^{\prime} 08^{\prime \prime}$ & 520 & AEMet \\
Villafría & $1943-2005$ & Burgos & $42^{\circ} 21^{\prime} 00^{\prime \prime}$ & $3^{\circ} 36^{\prime} 60^{\prime \prime}$ & 890 & AEMet \\
Boñar & $1990-2006$ & León & $42^{\circ} 45^{\prime} 00^{\prime \prime}$ & $5^{\circ} 19^{\prime} 22^{\prime \prime}$ & 975 & AEMet \\
\hline
\end{tabular}




\subsection{Dendrochronological analysis (studies I and II)}

In studies I and II, 8 P. halepensis sites (15 dominant and 15 suppressed trees per site), 10 $P$. pinaster sites (15 dominant trees per site) and $8 P$. sylvestris sites (15 dominant trees per site) were selected (Fig. 3, Table 1) and 2 increment cores were extracted from each selected tree. A total of 960 increment cores of P. halepensis (420), P. pinaster (300) and $P$. sylvestris (240) were analysed. The increment cores were air dried, mounted on wooden supports and dated according to standard dendrochronological techniques (Stokes and Smiley, 1996).

In order to assess the quality of crossdating and measurement accuracy of tree -ring series, the COFECHA program (Holmes, 1992) was applied. This program calculates the Pearson correlation indices between the indexed tree-ring series and a master reference chronology in a series of consecutive, partially overlapped segments of a length specified by the user. All series with potential dating errors or weakly correlated with the master site chronology were corrected when possible or discarded. According to standard dendrochronological methods, tree-ring series exhibiting correlation values with the master chronology below 0.4 were excluded. The proper use of COFECHA adds a high degree of confidence that tree -ring samples have been crossdated correctly and measured accurately, en- suring that the environmental signal is maximized (Grissino-Mayer, 2001).

The turbo ARSTAN program (Cook and Holmes, 1984; Holmes, 1992) was used to eliminate biological trends in tree-ring series and to minimize growth variations that are not shared by most trees. Standardization removes geometrical and ecological trends while preserving inter-annual high-frequency variations that are presumably related to climate. The long-term trend was removed from each time series of ring width measurements by fitting and calculating an index defined as actual ring-width for each year divided by the curve-fit value. Once the individual series were standardized, they were averaged in order to obtain a master chronology at each study site (one for dominant trees and one for suppressed trees in the case of $P$. halepensis). The master chronologies were examined separately to analyse differences in radial growth between species, sites and crown classes.

Chronology quality was evaluated using the following statistical parameters: 
- Mean sensitivity (MS): a measure of the mean relative changes between adjacent ring widths (Fritts, 2001).

- Signal-to-noise ratio (SNR): the proportion of the variability explained by climate or other casual factors divided by the residual or unexplained variability (Fritts and Swetnam, 1989).

- Expressed population signal (EPS): the degree to which the particular sample chronology portrays a hypothetically perfect chronology. Values higher than 0.85 imply that the chronologies are representative of tree growth in the stands (Wigley et al. 1984).

The master chronologies were normalized by subtracting the mean and dividing by the standard deviation. Values far from zero mean higher reactions. In the case of $P$. halepensis, the normalized difference index (NDI) was calculated by subtracting the normalized values of the suppressed trees to the normalized values of the dominant trees. Positive NDI values mean stronger reactions from dominant trees, while negative NDI values mean stronger reactions from suppressed trees.

Monthly climatic variables (precipitation sum and mean temperature) measured at the closest meteorological station (Agencia Estatal de Meteorología, Table 2) were divided in climatic seasons: winter previous to the growing season (December-February), spring (March-May), summer (June-August) and autumn (September-November) and regressed against ring-width indices. In order to calculate Pearson correlation coefficients and response functions DENDROCLIM 2002 (Biondi and Waikul, 2004) was applied. Moving correlation function was used to test stationarity and consistency through time with a 20year interval.

\subsection{IADFs occurrence (studies I and II)}

The accurately dated cores from studies I and II were visually examined for IADFs using a stereomicroscope (magnification up to 25x). As opposed to the annual rings, IADFs show a gradual transition boundary between earlywood and latewood cells (Fritts, 2001). IADFs were only considered when present in both cores in the same tree ring, and they were identified by considering the location of the density fluctuation within the ring. Only IADF 
type E (latewood-like cells within the earlywood) were considered in our study since IADFS type L (earlywood-like cells within the latewood) were rarely present in our sample. As the number of samples changed over time, the relative frequency was calculated with the following formula [1]:

[1] $\mathrm{F}=\mathrm{n} / \mathrm{N}$

where $\mathrm{F}$ is the proportion of IADF in a particular year; $\mathrm{n}$ the number of trees that formed the IADF and $\mathrm{N}$ the total number of trees analysed. The bias in the frequency was assessed by calculating the stabilized IADF frequency (f), according to the formula of Osborn et al. (1997) [2]:

$[2] f=F^{0.5}$

The nonlinear logistic equation form was chosen to model the probability of occurrence of IADFs [3]:

[3] $\mathrm{P}=\left(1.0+\mathrm{e}^{(-\mathrm{z})}\right)^{-1}$

where $\mathrm{P}$ is the probability of IADFs and $\mathrm{Z}=\mathrm{b} 0+\mathrm{b} 1(\mathrm{x} 1)+\mathrm{b} 2(\mathrm{x} 2)+\ldots \ldots+\mathrm{bk}(\mathrm{xk})+\varepsilon$; where $\mathrm{x} 1 ; \mathrm{x} 2 \ldots . . \mathrm{xk}$ are the climatic variables and $\mathrm{b} 0 ; \mathrm{b} 1 ; \mathrm{b} 2 \ldots . . \mathrm{bk}$ are unknown parameters of the model and $\varepsilon$ is a normal random error $\mathrm{N}(0,1)$; and $e$ is the exponential operator. The logistic equation can be formulated to accept a binary variable such as occurrence of IADFs, and the parameters can be estimated by maximum-likelihood methods. The resulting prediction is bounded by 0 and 1 . Monthly rainfall and mean monthly temperature were used as explanatory variables. The hydrological year was defined as a period of 12 months, from October of the previous year to September of the current growth year. A stepwise selection method was used to find the best model.

The alternative fits were evaluated on the basis of Akaike information criterion (AIC), the $2 * \log$ Likelihood, the area under the receiver operating characteristic (ROC) curve and the expected behavior - as indicated by the signs of the estimated parameters. ROC curve is displayed for the models and the area underneath was calculated as a value of the accuracy of the model. Value over 0.80 indicates an excellent discrimination (Hosmer et al., 2013). This curve relies on false/true positive/negative tests, and the sensitivity is indicated by the 
proportion of correctly classified events and the specificity by the proportion of correctly classified non-events (Hair et al., 1998).

Monthly climatic variables (precipitation sum and mean temperature) measured at the closest meteorological station (Agencia Estatal de Meteorología, Table 2) were grouped in climatic seasons: winter previous to the growing season (December-February), spring (March-May), summer (June-August) and autumn (September-November) and regressed against stabilized IADF frequency.

\subsection{Effects of thinning on growth dynamics and growth-climate relationships (study III)}

Study III is based on a thinning experiment conducted in autumn 2010 in a $P$. halepensis plantation located in Ampudia (Palencia) (study site number 4; Fig. 3, Table 1) (study III, Fig. 1, Table 1). The thinning experiment consisted of four $40 \mathrm{~m}$ x $50 \mathrm{~m}$ stands of similar basal area and stand structure were three thinning intensities were tested: $15 \%$ reduction of the total basal area (T15), 30\% reduction of the total basal area, (T30) and 45\% reduction of the total basal area, (T45) using an unthinned stand as control (T0) (study III, Fig. 2).

To estimate intra-annual changes in diameter increment, 48 stainless-steel band dendrometers (Dendrometer Increment Sensor DB20 EMS Brno) were mounted around the stem at $1.3 \mathrm{~m}$ height in 12 randomly chosen trees per treatment (6 dominant and 6 suppressed). Dominant trees were defined as those standing above all other trees in its vicinity and receiving full light from above, whereas suppressed trees were defined as those growing below the tree canopy. In most cases, the diameter of dominant trees ranged from 20 to $25 \mathrm{~cm}$ and suppressed trees from 10 to $15 \mathrm{~cm}$.

Before the installation of the dendrometers, the dead outermost tissue of the bark was smoothly and evenly removed with a rasp before attaching the dendrometer. The barks were removed in order to reduce swelling and shrinkage as a component of the increment dynamics. Dendrometer readings to the nearest $0.01 \mathrm{~mm}$ were done biweekly in the morning to reduce diurnal bias because daytime transpiration causes stem shrinkage (Zweifel et al., 2001). Measurements obtained in the first 3 months after installation were discarded for being within the adjustment period of the band dendrometers (Keeland and 
Sharitz, 1993).

Daily climatic variables measured at the closest meteorological station (Table 2) were averaged (or accumulated in the case of precipitation) in 5, 15 and 30 days prior to the growth measurements in order to determine which climatic variables were the main constraints for its growth and at which temporal scales they act. These intervals were chosen to detect delayed growth responses to changes of climate.

In addition to the climatic variables, soil water availability to the trees, which can be characterized by relative extractable water (REW), was included in the analysis. REW can be defined as the daily available water standardized by maximum available water. It was calculated by the daily water balance model Biljou@ (https://appgeodb.nancy.inra.fr/biljou/) (Granier et al., 1999). This model requires daily potential evapotranspiration and rainfall as input climatic data. Evapotranspiration was calculated with the Penman potential evapotranspiration equation. Required site and stand parameters are maximum extractable soil water and leaf area index (LAI). Soil conditions are considered homogeneous at the four plots (study III, Table 2). LAI controls stand transpiration, forest floor evapotranspiration and rainfall interception (Granier et al., 1999). LAI values differ depending on thinning intensities. The comparison between REW and radial increment on the four plots can be observed in study III, Fig. 3. Water stress is assumed to occur when REW drops below a threshold of 0.4 under which transpiration is gradually reduced due to stomatal closure (Granier et al., 1999).

In order to test similarity of growth rates prior to thinning among the four plots, increment cores were extracted from a total of 15 trees in the four plots. As preliminary trials, we fitted a linear model using past growth as response variable and a mixed model including a plot random effect. The relative goodness of fit of the models was assessed using the Akaike information criterion (AIC). Since AIC value (4399) did not change when the plot random effect was included, we concluded that the average growth was not different across the plots.

We fitted a linear mixed-effect model using the lme function with R-Package nlme (Laird and Ware, 1982). The model was fitted by maximizing the restricted log-likelihood: 
$G r_{i j k}=\beta_{0}+\beta_{1} * \operatorname{Clim}_{i k}+\beta_{2 i m}+\beta_{3} * S_{i j}+\beta_{4} *\left(\operatorname{Clim}_{i k} * S_{i j}\right)+\beta_{5 i m} * S_{i j}+b_{i j}+\varepsilon_{i j k}$

$b_{i j} \sim N\left(0, \sigma^{2}\right.$ Tree $)$

$\varepsilon_{i j k} \sim N\left(0, \sigma^{2}\left|\operatorname{Clim}_{i k}\right|^{2 \delta}\right)$

where $G r$ is the radial growth, Clim are the mean (or accumulated) values of the bioclimatic variables (temperature, precipitation, evapotranspiration and relative extractable water), $i$ is the plot index, $j$ is the tree index, $k$ is the two-week period index, $m$ is the thinning intensity index such that:

$m=1$ for the $15 \%$ thinning intensity

$m=2$ for the $30 \%$ thinning intensity

$m=3$ for the $45 \%$ thinning intensity

$S$ is an indicator variable for the status of the tree $(S=0$ for suppressed trees and $S=1$ for dominant trees), $b_{i j}$ is a tree random effect and the variance of the residual error terms $\varepsilon_{i j k}$ is modelled as $\sigma^{2}$, multiplied by the power of the absolute value of covariate Clim. The parameter $\delta$ is also estimated using a maximum likelihood estimator (see Zuur et al. 2009).

The period used for growth and climate analysis should corresponded only with the main period of stem growth (Deslauriers et al., 2007). Therefore, the period between 20 November 2011 and 15 April 2012 was excluded from the analysis in our study. Statistical analyses were performed using R software (R Development Core team, 2011).

Climate sensitivity is defined as the degree of growth response to climate variability. Because our growth data are intra-annual, the coefficient of variation (hereafter abbreviated as $\mathrm{CV}$ ), which shows the extent of variability in relation to the mean, was calculated in order to assess the climate sensitivity of the radial increment series. $\mathrm{CV}$ was calculated for the radial growth during the 2 -week growth periods on each tree and analysed for trees within status, plots and years. 


\subsection{Climate impact on wood density (study IV)}

In study IV, we analysed increment cores from one $P$. halepensis site (number 4; Fig. 3, Table 1), one $P$. pinaster site (number 16; Fig. 3, Table 1) and one $P$. sylvestris site (number 24; Fig. 3, Table 1). 15 dominant trees were selected at each site and 2 increment cores were extracted at $1.3 \mathrm{~m}$ from each selected tree. The samples were processed following standard techniques (Stokes and Smiley, 1996), conditioned to a $12 \%$ water content and resawn in the transverse plane to a thickness of $2 \mathrm{~mm}$. X-Ray negative photographs of the samples were obtained and the resulting X-ray picture was processed with CERD software (Mothe et al., 1998). The wood density profiles obtained are for each ring and are based on 100 measured positions. Density profiles were produced by averaging the values (XRD, kg/m3) obtained from these segments (Bouriaud et al., 2005; Rathgeber et al., 2006).

To remove non-climatic age trends from the raw measurements, tree-ring width series were detrended (standardized) on a modified negative exponential curve using the package dplR (Bunn, 2008) in R. The standardization removes the geometrical and ecological trends while preserving inter-annual high-frequency variations that are presumably related to climate. The long-term trend was removed from each time series of ring width measurements by fitting and calculating an index defined as actual ring-width for each year divided by the curve-fit value.

Mean monthly temperatures and monthly precipitations recorded at the closest meteorological stations (Agencia Estatal de Meteorología, Table 2) were divided in climatic seasons: winter previous to the growing season (December-February), spring (March-May), summer (June-August) and autumn (September-November) and correlated with tree-ring width, earlywood width, latewood width, mean density, maximum density, earlywood density and latewood density. 


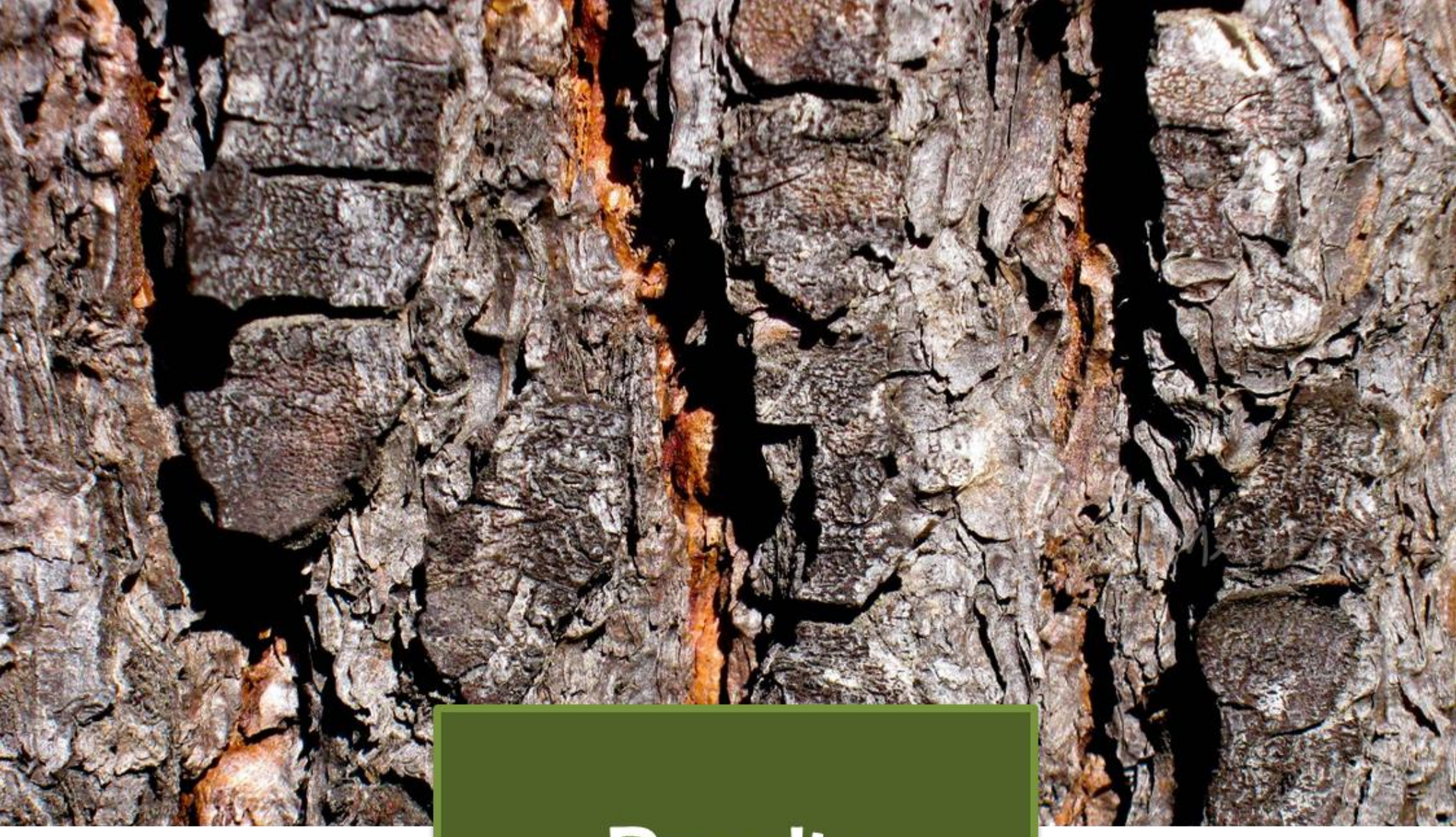

\section{Results}


Olivar (2013) 


\section{RESULTS}

\subsection{Dendrochonological study of P. halepensis trees of different crown classes (study I)}

Two master chronologies were calculated for each sampling site, one for dominant trees and one for suppressed trees. In sites $\mathrm{Za} 1$ and $\mathrm{Za} 2$ only a master chronology of the dominant trees was calculated (study I, Fig. 3). The master chronologies from Ampudia showed higher mean sensitivity (MS) values (0.40 for dominants and 0.37 for suppressed) than the other locations (study I, Table 2). The master chronology of the dominant trees in Ampudia also showed higher SNR and EPS (66.08 and 0.98 respectively) than the rest of the locations. The mean chronology of the suppressed trees showed slightly higher mean sensitivity values ( 0.30 for dominants and 0.33 for suppressed) and higher SNR values (26.64 for dominants and 12.77 for suppressed) than the mean chronology of the dominant trees. The mean chronology of the dominant trees also showed higher variance and mean correlation values than the mean chronology of the suppressed trees (study I, Table 3).

The normalized curves are shown in study I, Fig. 3. It can be observed that dominant trees have stronger reactions than suppressed trees in favourable years in Ampudia while in Tarazona suppressed trees react stronger than dominant trees in favourable years, the other sites show no patterns. The Normalized Difference Index (study I, Fig. 4) showed that, from 1980 to 2000 suppressed trees reacted stronger in Murcia and Aragón, while since 2000 no clear tendency was found.

\subsection{Climate-growth relationships over time in Mediterranean pine species ( $P$. halepensis, P. pinaster and P. sylvestris) in Spain (study II)}

Precipitation proved to be the main factor influencing tree growth on the three species. While $P$. halepensis and $P$. pinaster were influenced by wet periods during winter previous to the growth season and spring, $P$. sylvestris was mostly influenced by summer precipitation. Pinus pinaster showed the highest correlations $(p<0.005)$ between precipitation and growth ( $\mathrm{r}=0.12$ in average) (study II, Table 2). 
The analysis of the influence of the climatic variables over time also differed between the three species. They experienced a shift in the influence of different climatic variables on its growth at the last third of the $20^{\text {th }}$ century. The positive influence of winter, spring and summer precipitation on $P$. halepensis growth increased from the 1990 s decade (study II, Fig. 3). During that period, spring temperature shifted its influence from negative to positive, while summer temperature shifted from positive to negative. In the case of $P$. pinaster (study II, Fig. 3), the highest changes on the influence of the climatic variables on its growth occurred during the 1970s decade, where spring precipitation became its higher influence followed by summer and winter precipitation. Also during that period, winter temperature increased its positive influence; while the influence of spring, summer and autumn temperature became negative. Summer precipitation had the highest correlation values (0.33) on P.sylvestris (study II, Fig. 4) and remained essentially stable during the study period. Winter and spring temperature also had a positive influence on its growth, while summer temperature shifted its influence from positive to negative around 1980.

\subsection{IADF formation over time in Mediterranean pine species (P. halepensis, $P$. pinaster and $P$. sylvestris) in Spain (studies I and II)}

In study I, a detailed analysis of the IADF formation in $P$. halepensis was carried out. Samples were grouped according to site location (study I, Table 4) age (study I, Table 5) and crown class (Table 6, I). The percentage of trees with IADFs was rather similar for young and old stands. However, the proportion of IADFs and the mean stabilized IADF was higher for young stands than for old stands. The percentage of trees with IADFs and the percentage of IADFs were both higher for suppressed than dominant trees. Mean stabilized IADF was the same for both crown classes.

In study II, $P$. pinaster and $P$. sylvestris were included in the analysis in order to have a more global understanding of IADF formation in pine species growing under Mediterranean climate. The nonlinear logistic equation form was chosen to model the probability of occurrence of IADFs in the three species with monthly precipitation and mean monthly temperature as variables. Pinus pinaster had the highest accumulated mean stabilized IADF frequency (0.12), followed by $P$. halepensis (0.03). The occurrence of IADFs was mainly influenced by precipitation on the three species. Precipitation in the 
winter previous to the growing season and spring were associated with the occurrence of IADFs in $P$. halepensis, while this influence was postponed on time in the case of $P$. pinaster, influenced by spring and early summer precipitation. Both species showed a negative influence of precipitation in July. The IADF frequency $P$. sylvestris was the lowest of the three species (0.004). IADF frequency in relation to calendar year (study II, Fig. 5) showed an increase in IADF occurrence in the second half of the century. 1961, 1983, 1995 and 1999 were the years with higher of IADF occurrence, with a stabilized frequency higher than 0.8 .

\subsection{Effects of thinning on growth dynamics and growth-climate relationships in $P$. halepensis trees of different crown classes (study III)}

The thinning experiment performed in study III revealed soil water content, represented by relative extractable water (REW) as the main bioclimatic variable which influenced tree radial growth of $P$. halepensis. Nonetheless, its influence on growth differed with crown classes. The results of the linear mixed-effect model applied for each variable (temperature, precipitation, evapotranspiration and REW) confirmed that REW averaged for the previous 15 days was the main bioclimatic variable that influenced tree radial growth at the studied stands (Study III, Table 3).

We fitted the model with mean REW of the previous 15 days (study III, Table 4) as climatic variable. Results showed that dominant trees and trees in T30 and T45 had significantly higher growth rates. The comparison between real growth and predicted values of the model for T0 and T45 are shown in study III Fig. 4. Model predictions are more accurate for dominant than suppressed trees and for T45 than T0.

Study III, Fig. 5 describes the growth patterns of the four stands. As it is typical for Mediterranean species, the growth dynamics of $P$. halepensis showed a bimodal growth pattern, with two major growth phases in spring and autumn and low rates in late summer and beginning of autumn. The spring maximum increment rate was higher than the autumn maximum increment rate, except for T0 in 2011. The growth rates of the dominant trees (mean=1.23 $\mathrm{mm}$ in 2011 and $0.68 \mathrm{~mm}$ in 2012) were significantly higher $(p<0.05)$ than the growth rates of the suppressed trees (mean $=0.45 \mathrm{~mm}$ in 2011 and $0.18 \mathrm{~mm}$ in 2012). Both 
growth rates decreased in 2012. The analysis of the variance of the growth data (study III, Fig. 6) showed that suppressed trees had higher CV values than dominant trees. T45 showed the lowest CV values in both crown classes during the two years of study.

\subsection{Climate impact on wood density in $P$. halepensis, $P$. pinaster and $P$. sylvestris (study IV)}

Tree-ring width of $P$. halepensis was positively correlated to precipitation during previous winter and spring ( $p$-values>0.005) and spring temperature ( $p$-value>0.05). Tree-ring width of $P$. sylvestris was positively correlated to summer precipitation $(p$-value $>0.05) P$. pinaster showed no significant correlations between tree-ring width and climatic variables (study IV, Fig. 3). Earlywood width of $P$. halepensis was positively correlated to precipitation during previous winter and spring ( $p$-values $>0.005$ ), while its latewood width was positively correlated to spring temperature $(p$-value $>0.05)$ and winter precipitation ( $p$ value >0.05) (study IV, Fig. 3).

Mean and maximum density followed different patterns on the three species, decreasing along time in $P$. pinaster and increasing in P. halepensis and P. sylvestris. Pinus halepensis showed higher values of mean density than the other two species and $P$. pinaster showed lowest values of maximum density than the other two species (study IV, Fig. 4 and 5). The analysis of the climate-density relationships showed that mean density of $P$. halepensis was negatively correlated to precipitation during previous winter ( $p$-value>0.05) and spring ( $p$ value $>0.005)$ and to spring temperature ( $p$-value>0.05). Mean density of P. sylvestris was positively correlated to autumn temperature ( $p$-value>0.05) (study IV, Fig. 6). Pinus pinaster showed no significant correlations between mean density and climatic variables. Early wood density was negatively correlated to precipitation during previous winter ( $p$ value $>0.05)$ and spring ( $p$-value $>0.005)$ and to spring temperature ( $p$-value $>0.05)$ in $P$. halepensis; positively correlated to summer temperature in $P$. pinaster and positively correlated to spring and autumn temperature in $P$. sylvestris (study IV, Fig. 7).

We calculated the growth and density trends of our sample and compared them to 5-year moving averages (study IV, Fig. 8 and 9). A decrease in growth rates was observed in the three species, with high variability of the growth data especially during the most recent 
years. However, the 5-year moving average followed the decreasing patterns on the three species with lower variability. Mean density rates was showed an increase in sensitivity that did not occur in the 5-years moving averages. 
Olivar (2013) 
Olivar (2013) 


\section{DISCUSSION}

\subsection{Dendrochonological study of P. halepensis trees of different crown classes (study I)}

Pinus halepensis showed good correlations between trees growing at the same site and high expressed population signals which suggest a clear response to environmental factors, proving to be a reliable species for dendrochronological studies. In addition, it confirms the tendency of Mediterranean species to develop special anatomical structures (Schweingruber, 1993). We found common radial growth patterns among dominant and suppressed series in the same site. These results agree with previous studies in the Iberian Peninsula suggesting that pine species growing in the southern dendroecological section could have a common growth response to environmental factors (Richter et al., 1991; Bogino and Bravo, 2008).

The descriptive statistics of the chronologies suggest that the tree-ring series reflects one or more associated factors (including climate), and a strong response of radial growth dynamics to changes in climatic conditions shown by the mean sensitivity values (MS) from 0.21 to 0.40 that are higher than the 0.16 to 0.34 values found in previous studies on pine species (Pinus sylvestris L., Pinus nigra Arnold, Pinus pinaster Ait. and Pinus mugo ssp. uncinata Turra.) in the Iberian Peninsula (Richter et al., 1991; Bogino and Bravo, 2008, Martín-Benito et al., 2008; Bogino and Bravo, 2009; Bogino et al., 2009; Vieira et al., 2009).

The expressed population signal (EPS) ranging from 0.89 to 0.98 is in all cases higher than the critical level of 0.85 suggested by Wigley et al. (1984), which implies that the chronologies are representative of tree growth in the stands. First eigenvector variance ranges from 39.90 to $74.82 \%$, indicating good homogeneity within the same site. It can be concluded that the fourteen mean chronologies have high MS, SNR, EPS and percentage of the variance accounted for by the first eigenvector, suggesting a strong common signal to related-climatic environmental factors. Ampudia showed higher values of MS, SNR and EPS than the other two locations, especially the dominant trees. However, in the regions of Aragón and Murcia the mean suppressed series showed a higher sensitivity than the mean 
dominant series. There is evidence that suppressed trees suffer greater drought stress because of greater root competition for soil. However, understory trees receive lower solar radiation and higher wind protection by the influence of neighbouring crowns reducing transpiration rates. Therefore, climate sensitivity may be reduced (Bréda et al., 2006; Martín-Benito et al., 2008). In Mediterranean forests tree density is low and the protection effect from the dominant to the suppressed trees is reduced.

\subsection{Climate-growth relationships over time in Mediterranean pine species ( $P$. halepensis, $P$. pinaster and P. sylvestris) in Spain (study II)}

A change in tree-growth pattern and in the climatic response of the studied species was detected since the mid-20th century and linked to an increase in water stress. These temporal trends were in agreement with the observed increase in warmer conditions and in precipitation variability (Andreu et al., 2007). Precipitation is the main factor influencing tree growth of pine species in semiarid Mediterranean conditions (Raventós et al., 2001). The growth of $P$. halepensis, $P$. pinaster and $P$. sylvestris is mainly controlled by precipitation at different times of the year. Winter and spring precipitation is related positively with tree-ring growth in $P$. halepensis and $P$. pinaster, while the growth of P.sylvestris is mostly influenced by summer precipitation. These results are consistent with those of previous studies in P. halepensis in Greece and Spain (Papadopoulos et al., 2009; Olivar et al., 2012), P. pinaster in Portugal (Vieira et al., 2010; Campelo et al., 2013) and central Spain (Bogino and Bravo, 2008), and P. sylvestris at its southern and western distribution limits (Bogino et al., 2009). However, the influence of these climatic variables on the growth of these species changed along the studied period. The positive influence of winter and spring precipitation on $P$. halepensis growth increased from the 1990 s decade and the positive influence of spring precipitation on $P$. pinaster growth increased from the 1970s decade, while the positive influence of summer precipitation on $P$. sylvestris growth remained stable. These results agree with previous reports on pine species in the Mediterranean area (Andreu et al., 2007; Bogino and Bravo, 2008; Vieira et al., 2010; Campelo et al., 2013).

Global studies around the Mediterranean basin indicate that winter and spring precipitation increased and summer precipitation decreased during the second-half of the 20th century 
(Bradley et al., 1987; Maheras, 1988; Diaz et al., 1989). Mediterranean pines evolved during the Pliocene under tropical-like climate, before the onset of the Mediterranean climate, as a component of the pre- Mediterranean Arcto-Tertiary flora (Verdú et al., 2003; Petit et al., 2005). These species survived to a past gradual increase of aridity during the transition to Mediterranean conditions, which may have led to its characteristic growth plasticity (Chambel et al., 2007). Mediterranean Pinus species are considered as a species well adapted to withstand drought by reducing growth as water availability decreases and increasing growth as conditions become favourable (Rathgeber et al., 2005; de Luis et al., 2007; Camarero et al., 2010; Pasho et al., 2012). This increase of winter and spring precipitation combined with the rising hardening of the climatic conditions during summer may have enhanced the importance of precipitation at the beginning of the growing season on the growth of species subject to higher drought stress conditions during summer, such as $P$. halepensis and $P$. pinaster.

Frequently, climate becomes highly limiting to physiological processes for tree species at the edge of their natural range, because trees on these sites are particularly susceptible to climatic variations (Fritts, 2001). Our study was carried out in Spain with P. sylvestris at the edge of its phytogeographical distribution area (southern and western distribution limit). Distribution of the forests in Spain is highly determined by the Atlantic and Mediterranean climatic influences. However, most $P$. sylvestris forests are restricted to the mountainous areas where relief causes important variations to the regional climate and water availability is not limited during the whole year (Blanco et al., 1997; Barbéro et al., 1998). Therefore, P.sylvestris did not suffer that shift in the influence of the climatic variables.

\subsection{IADF formation over time in Mediterranean pine species ( $P$. halepensis, $P$. pinaster and P. sylvestris) in Spain (studies I and II)}

We found a higher tendency in young $P$. halepensis stands for developing IADFs. These results corroborate previous dendroecological studies which suggested that IADFs were more frequent in younger tree rings (Villalba and Veblen, 1996; Rigling et al., 2001; Bogino and Bravo, 2009; Vieira et al., 2009). This could be due to a faster response of young trees to changing factors (Villalba and Veblen, 1996) and/or to a longer growing season of young trees (Rossi et al., 2008). Since young trees have a different response to 
environmental factors than old trees, the incorporation of age-dependent differences on the appearance of special ring features such as IADFs and its association to climatic variables in any dendrochronological study provides a useful proxy for complementing and enhancing the dendroclimatological data. In addition, it can give important clues to predict differences on how young and old trees react to climate change.

IADFs may appear at different development phases of the tree-ring formation depending on the time of the year when the stress conditions occurred. IADF type $\mathrm{E}$ is triggered by dry periods during spring and early summer. In contrast, IADF type L is triggered by precipitation during late summer and (or) early autumn (Wimmer et al., 2000). Previous studies in the Mediterranean area showed a high frequency of IADFs in latewood (de Luis et al., 2007; Vieira et al., 2010; Rozas et al., 2011; Campelo et al., 2013; Novak et al., 2013;). However, the low frequency of IADF type L and the high frequency of IADF type E observed in our samples indicate a higher occurrence of water stress episodes inhibiting cell division and enlargement during the first part of the growing season. The ability of species to produce different types and forms of cells in different periods may also be interpreted as an important adaptation of trees for maintaining the balance among the capacity to conduct water, resistance to cavitation and mechanical stability (Novak et al., 2013).

The analysis of the climatic influence in IADF occurrence revealed that the formation of IADFs is triggered by above-average precipitation in the previous winter and spring in $P$. halepensis and in spring and early summer in $P$. pinaster, being both negatively influenced by precipitation in July. These climatic conditions (precipitation at the beginning of the growing season and summer droughts) have been increasingly favoured over the second half of the $20^{\text {th }}$ century, explaining the increasing occurrence of IADFs our study area. This result agrees with previous studies that found an increase in IADF frequencies after 1980 in P. pinaster in Spain (Bogino and Bravo, 2009) and Portugal (Vieira et al., 2010; Campelo et al., 2013). Despite being at its southern distribution threshold, where a species that usually grows in humid environments could suffer from the effects of increased aridity (Martínez-Vilalta and Piñol, 2002), P. sylvestris showed the lowest IADF frequency of the three species on our sample. As pointed out by Battipaglia et al. (2010), the frequency and 
the triggering climatic factors promoting different anatomical characteristics may vary among populations, depending on different environmental conditions. As previously pointed out in the case of the swift in the influence of the climatic variables, most $P$. sylvestris forests are restricted to the mountainous areas where relief causes important variations to the regional climate and water availability is not limited during the whole year (Blanco et al., 1997; Barbéro et al., 1998). Therefore, P.sylvestris did not suffer the triggering climatic conditions for IADF occurrence.

\subsection{Effects of thinning on growth dynamics and growth-climate relationships in $P$. halepensis trees of different crown classes (study III)}

The thinning experiment performed in study III revealed that the most intense thinning treatments (30\% and $45 \%$ removal of the basal area) induced a growth release on both crown classes that did not occur under less intense thinning treatments. $15 \%$ treatment was not intense enough to increase growth of dominant trees. Thinning is less effective at dry sites if it is not intense enough, because inter-tree competition for water is stronger, so that site conditions cannot support high-density stands (Moreno and Cubera, 2008; Cotillas et al., 2009; Linares et al., 2009). Thus, a still high competition level that is not sufficiently removed by thinning, coupled with the more limiting climatic conditions, should have obscured the advantages of thinning on less intense thinning treatments (Misson et al., 2003). Growth variability was higher in suppressed than in dominant trees. $45 \%$ treatment showed the lowest coefficient of variation (CV) values in both crown classes, which means higher homogeneity of the growth data. These results are in agreement with the idea that in semi-arid environments, suppressed trees usually have more limited access to soil water reserves than dominant trees, due to their shallower and less developed root systems, especially in high density stands. Therefore, their growth rates fluctuate depending on short term water reserves concentrated in surface soil layers, while dominant trees with more developed root systems and suppressed trees released from competition show more homogeneous growth rates.

Adequate stand density levels determination is a difficult task that involves biological, technological, economical and operational factors drive by species, site and management frameworks. Mediterranean species as P. halepensis did not have a high productivity, and 
this implicates than the management costs must be minimized to obtain equilibrate economic balance. Mediterranean pine stands in Spain show high, aesthetic, biodiversity values that are key factors in forest management but have no market price, due to low productivity. Simple, cheap and easy-to-use tools are needed to help managers to fulfil society's demands and management objectives (Valbuena and Bravo, 2008). In addition, with rising living standards, protective, environmental, social and cultural functions became more important. Changing social demands today require a widened scope of forest management and principles of sustainable forest management (Spiecker, 2003).

The reduction of stand density through thinning has been suggested to improve the resistance of individual trees to drought stress and the extent of this differential response changes within the same species along climatic gradients (Misson et al., 2003; Moreno and Cubera, 2008; Gea-Izquierdo et al., 2009). However, this conclusion should not be extrapolated to generalise that open stands are always desirable (Gea-Izquierdo et al., 2009). Forest managers should adequate stand density to mitigate the effect of climatic extremes taking other ecosystem parameters such as regeneration or soil protection into account. Less dense and more diverse stands could be promoted by mixing species with different drought resistance to avoid or limit further growth declines in plantations.

The growth dynamics of $P$. halepensis had two major growth phases during the growth period, one in spring and another in autumn, interrupted by a period with low or no cambial activity during late summer as a result of drought and high temperatures (Cherubini et al., 2003). This pattern of xylem production is responsible for the frequent formation of intraannual density fluctuations observed in this species (study I). Stem growth started at middle March in 2001 and April in 2012, when temperatures were high enough for vegetative growth, and stopped growing at the end of November in both years, when temperatures were too low. The radial growth pattern of $P$. halepensis was asymmetrical with most of the annual growth occurring in spring. The maximum growth rate in spring was the highest of the year except for the control treatment in 2011, where the autumn maximum growth rate was higher. Growth patterns of $P$. halepensis showed high-plasticity in response to climatic conditions during the growing period, which may be an advantage in areas with a Mediterranean climate where the annual rainfall pattern is variable (Gutiérrez et al., 2011). 
Pinus halepensis has been characterized as a sensitive Mediterranean species based on the strong response of growth dynamics to changes in climatic conditions (Lev-Yadun, 2000). It has also been suggested that the cambium is able to remain active throughout the whole year when climate conditions are favourable (Liphschitz et al., 1984).

Relative extractable water (REW) was the main bioclimatic variable which influenced tree radial growth at the studied stands. These results add information to studies I and II that defined precipitation during previous winter and spring as the main climatic driver of its growth. The utilisation of soil moisture, rather than precipitation, is a way to reduce the structural difference between water and temperature variables, and thus to improve the "behaviour" of response functions. Furthermore, soil moisture has more biological meaning than precipitation because it better reflects water availability for trees. These points are particularly relevant for studies performed in Mediterranean regions (Rathgeber et al., 2005).

In the Mediterranean area with a continuous water deficit, at least for P. halepensis, wood formation reflects environment conditions for most part of the year, and a precipitation event is generally followed within a time less than a week, by an increase of growth rate (Attolini et al., 1990). Water availability is expected to be the major limiting factor for growth under a Mediterranean climate and its influence decreases with altitude in the Mediterranean region, with temperature showing the opposite trend (Cherubini et al., 2003). There is a general idea that radial growth is primarily dependent on the short-term water availability, which affects the actual tree water status and xylogenesis (Eilmann et al., 2009). In the studied stands, the influence of REW on dominant and suppressed trees was different. In drought stressed environments, suppressed trees usually have shallower and less developed root systems than dominant trees, and less moisture is available to them (Van Lear and Kapeluck, 1995). Therefore, the amount of available water for suppressed trees is limited to the short term water reserves concentrated in surface soil layers; while dominant trees, with more developed root systems can access to deeper soil water reserves accumulated in longer terms (Camarero et al., 2010), inducing higher vulnerability of suppressed trees to water stress. 
4.5. Climate impact on wood density in $P$. halepensis, $P$. pinaster and $P$. sylvestris (study IV)

Mean and maximum wood density levels increased outwards from the pith to the stem surface in P. halepensis and P. sylvestris, as found earlier by Kellomäki et al. (1999). However, $P$. pinaster showed a more linear decrease in mean and maximum densities. Büntgen et al. (2010) suggested that this decrease might be related to (i) a systematic decrease in the ratio between cell wall size and lumen area with increasing tree age, or alternatively (ii) that the annual lignin content decreases with age.

P. halepensis mean density was inversely correlated to precipitation in the previous winter and spring, the climatic conditions that enhanced its radial growth. Rainfall in the early part of the growing season extends the production of earlywood, resulting in a lower density wood (Wimmer and Downes, 2003). Therefore, the negative effect of precipitation on wood density is accordingly consistent with its positive effect on radial growth. Gilmore (1968) also concluded that factors, which extend the production of earlywood, result in lower wood density wood. During the first part of the growing season, climatic variations affect radial enlargement, whereas during the later part of the growing season, climatic variations only affect the cell wall thickening process (Bouriaud et al., 2005; Büntgen et al., 2010). Detailed experiments showed that maximum tracheid production corresponded to maximum day length, thus allowing cell wall formation and lignification to be completed by the end of summer (Rossi et al., 2006).

Bouriaud et al. (2005) found a strong positive correlation between soil water deficit and wood density, which they attributed to temperature-mediated reductions in the radialgrowth rates due to an increasing soil-water deficit. Cell wall thickness variations play a major role in the wood density variations (Decoux et al., 2004). Rathgeber et al. (2006) suggested that wood density increase is mainly due to cell-wall thickening in tangential and radial directions as well as cell size reduction in radial direction. The reduction in tracheid radial enlargement might also be associated with thicker cell walls (Linares et al., 2009).

There is a general understanding that water stress has a major impact on various aspects of wood formation through direct effects of cell turgor as well as changes in hormonal 
balances and carbohydrate storage (Kramer, 1964). Similar effects of water availability on wood density were also observed for Picea abies (Wimmer and Downes, 2003; Bouriaud et al., 2005), P. halepensis and P. pinaster (studies I and II), where wood density was found to increase in association with increased drought stress, creating a false ring. The positive effect of temperature on wood density is a consequence of its negative effects on radial growth rate (D’Arrigo et al., 1992; Yasue et al., 2000; Bouriaud et al., 2005).

Maximum density of $P$. halepensis was positively correlated with climatic conditions favoring tree ring width, agreeing with the idea that favorable years with good climatic conditions at the beginning of the growing season increase the length of the growing period and, therefore, the duration of tracheid maturation, which determines the final cell wall thickness (Wodzicki, 1971; Horacek et al., 1999), and the wall thickness of the latewood cells is the most important factor affecting the tree-ring maximum density (Yasue et al., 2000; Linares et al., 2009).

Especially for coniferous species, relationships between maximum latewood density and climatic variables such as late summer temperature have been established, and are widely used for climate reconstructions (Parker and Henoch, 1971; Schweingruber et al., 1978; Conkey, 1979; D’Arrigo et al., 1992; Briffa et al., 2001; Büntgen et al., 2010). However, these studies were conducted in temperate regions and not in the Mediterranean region. In our study only $P$. sylvestris, growing in higher altitude and having more favorable water conditions showed a positive correlation between maximum latewood density and summer temperature, while $P$. halepensis and $P$. pinaster, subjected to summer water stress showed negative correlations between maximum latewood density and summer temperature. These negative correlations may be due to the low or inexistent growth rates of the trees in that period.

Due to the observed changes in growth-climate associations of pine species during the last part of the 20th century (study II) we calculated the variance of the growth and wood density trends of our sample and compared them to a 5-year moving average (the typical modeling horizon) and a 5-year moving weighted average respectively. An increase in the climate sensitivity was observed in both trends during the last years, producing high irregularity in tree ring width and mean density. However, this irregularity is not observed 
in the 5-year moving interval, where low growth rates of some years are compensated with high growth of the surrounding years. These results indicate that, despite the increasing climate sensitivity of pine species during the most recent years, the trend in growth and mean density does not change in a 5-year interval. However, these inter-annual variability could have an effect on wood properties producing a loss of wood quality (Persson et al., 1995). 


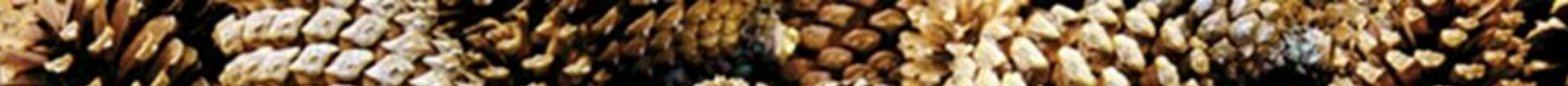

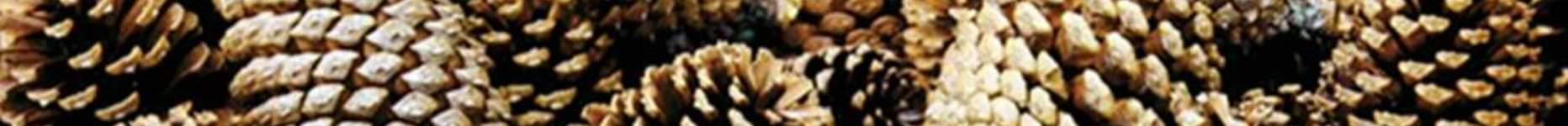

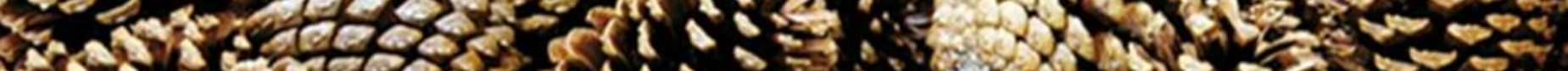

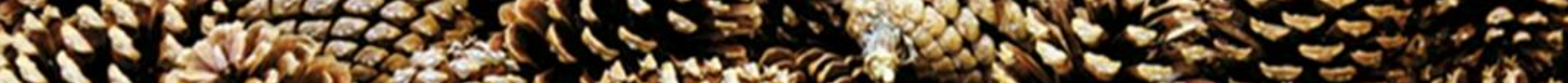

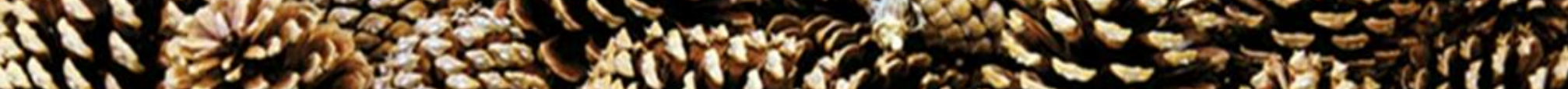

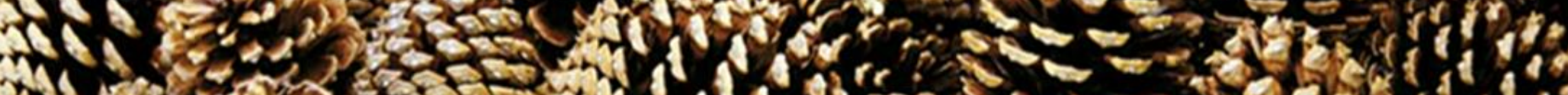

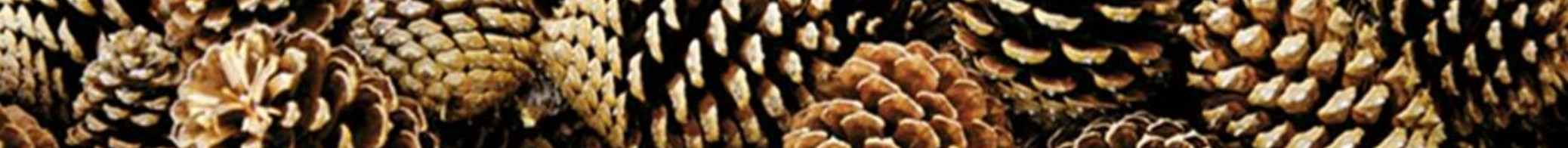

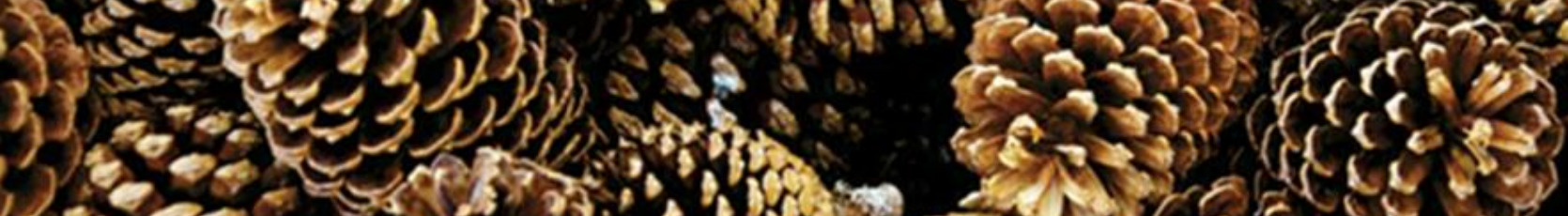

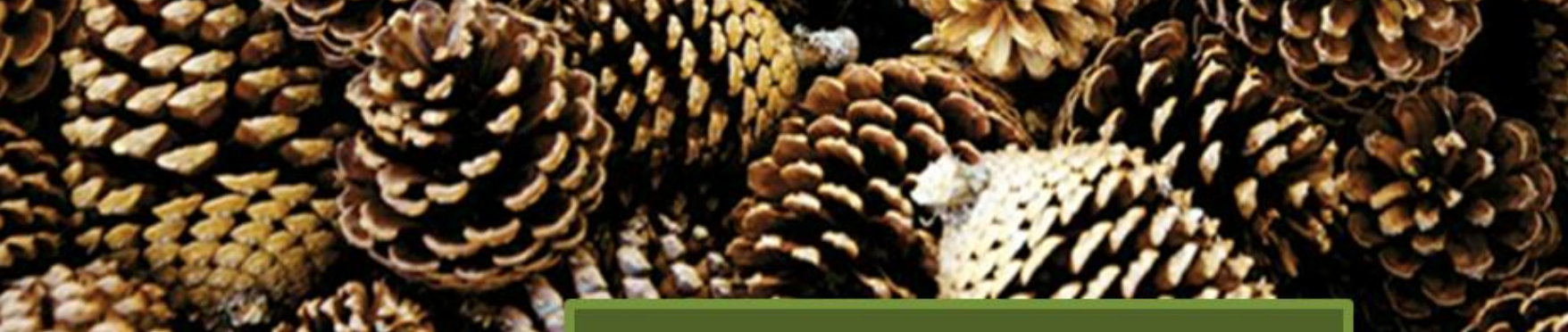

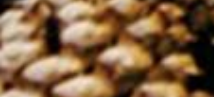
25. $20 x+4=2$

\section{Conclusions}


Olivar (2013) 


\section{CONCLUSIONS}

The following conclusions can be drawn from the studies that compose this thesis:

- Pinus halepensis showed good correlations between trees growing at the same site, high expressed population signals and accurate statistical values which indicate a clear response to environmental factors, proving to be a reliable species for dendrochronological studies.

- The growth of $P$. halepensis, $P$. pinaster and $P$. sylvestris is mainly controlled by precipitation at different times of the year. Winter and spring precipitation is related positively with tree-ring growth in $P$. halepensis and $P$. pinaster, while the growth of $P$. sylvestris is mostly influenced by summer precipitation.

- The formation of IADFs is triggered by above-average precipitation in the previous winter and spring in $P$. halepensis and in spring and early summer in $P$. pinaster, being both negatively influenced by precipitation in July.

- A change in tree-growth pattern and in the sensitivity of climatic response of $P$. halepensis and $P$. pinaster has been detected since the mid-20th century and linked to an increase in water stress. Pinus sylvestris, restricted to the mountainous areas where water availability is not limited during the whole year, did not suffer that shift in the influence of the climatic variables.

- Radial growth of $P$. halepensis was mainly controlled by soil water availability during the growing season and differed across the crown class.

- The most intense thinning treatments (30\% and $45 \%$ removal of the basal area) reduced the effects of water limitations on individual tree growth.

- Climatic conditions promoting the increase in radial growth produced low mean wood density values in $P$. halepensis. However, the same climatic conditions produced high maximum wood density values.

- Pinus sylvestris, growing in higher altitude and having more favorable water conditions showed a positive correlation between maximum latewood density and summer 
temperature; while $P$. halepensis and $P$. pinaster, subjected to summer water stress producing low or inexistent growth rates of the trees in that period, showed negative correlations.

- Despite the increasing climate sensitivity of pine species during the most recent years, the trend in growth and mean density does not change in a 5 year interval (the typical modeling horizon) so modeling predictions are not affected. However, these inter-annual variability could have an effect on wood properties producing a loss of wood quality. 


\section{CONCLUSIONES}

A continuación se presentan las conclusiones más importantes derivadas de cada uno de los estudios realizados:

- Pinus halepensis mostró altas correlaciones entre árboles del mismo rodal, altos valores de la señal de población expresada y valores estadísticos que indican una clara respuesta a factores ambientales, demostrando ser una especie con alto potencial para estudios dendrocronológicos.

- El crecimiento de $P$. halepensis, $P$. pinaster y $P$. sylvestris está fundamentalmente controlado por las precipitaciones en distintos periodos del año. Las precipitaciones durante el invierno previo y la primavera están positivamente correlacionadas con el crecimiento en $P$. halepensis y $P$. pinaster, mientras que el crecimiento de $P$. sylvestris está fundamentalmente influenciado por las precipitaciones durante el verano.

- La formación de IADFs está asociada a altas precipitaciones durante el invierno previo y la primavera en $P$. halepensis, y a las precipitaciones en primavera y el principio del verano en $P$. pinaster, siendo negativamente influenciadas por las precipitaciones en el mes de Julio en ambas especies.

- Se ha detectado un cambio en los patrones de crecimiento y en la sensibilidad climática de P. halepensis y P. pinaster a partir de 1980 ligado a un aumento del estrés hídrico. Pinus sylvestris, restringido a áreas de montaña donde la disponibilidad de agua es constante durante todo el año, no ha sufrido ese cambio.

- El crecimiento radial de P. halepensis estuvo fundamentalmente controlado por la disponibilidad de agua en el suelo durante el period vegetativo, pero su efecto varia dependiendo de la clase de copa.

- Los tratamientos de clara más intensos (eliminación del 30 \% y 45 \% del área basimétrica) disminuyeron el efecto del estrés hídrico en el crecimiento radial de los árboles.

- Las condiciones climáticas que fomentaron un aumento en el crecimiento radial de P. 
halepensis también produjeron un descenso de su densidad media. Sin embargo, las mismas condiciones climáticas produjeron un aumento de su densidad máxima.

- Pinus sylvestris, al crecer en mayor altitud y tener unas condiciones hídricas más favorables que las otras dos especies, mostró una correlación positiva entre la densidad máxima de la madera tardía y la temperatura del verano; mientras que $P$. halepensis y $P$. pinaster, con bajos niveles de crecimiento en verano debido al estrés hídrico, mostraron correlaciones negativas.

- A pesar del aumento de la sensibilidad climática durante los últimos años, los patrones de crecimiento y densidad no varían en un intarvalo de 5 años (el típico horizonte de modelización) por lo que las predicciones de los modelos no se ven afectadas. Sin embargo, esas variaciones inter-anuales pueden afectar las propiedades de la madera produciendo un descenso de su calidad. 
Olivar (2013) 


\section{REFERENCES}

Adams, H.D., Kolb, T.E., 2004. Drought responses of conifers in ecotone forests of northern Arizona: tree ring growth and leaf $\delta 13 \mathrm{C}$. Oecologia 140: 217-225.

Alía, R., Martín, S., de Miguel, J., Galera, R., Agúndez, D., Gordo, J., Salvador, L., Catalán, G., Gil, L., 1996. Regiones de procedencia de Pinus pinaster Aiton. Dirección Gen. Conserv. Nat. Madr.

Andreu, L., Gutiérrez, E., Macias, M., Ribas, M., Bosch, O., Camarero, J.J., 2007. Climate increases regional tree-growth variability in Iberian pine forests. Glob. Change Biol. 13: 804-815.

Attolini, M.R., Calvani, F., Galli, M., Nanni, T., Ruggiero, L., Schaer, E., Zuanni, F., 1990. The relationship between climatic variables and wood structure in Pinus halepensis Mill. Theor. Appl. Clim. 41: 121-127.

Barbéro, R., Loisel, R., Quezel, P., 1998. Ecology and Biogeography of Pinus, In: Ecology and Biogeography of Pinus (ed. Richardson DM), pp. 153-170. ed. Cambridge University Press.

Blanco, E., Casado, M.A., Costa, M., Escribano, R., García, M., Génova, M., Gómez, A., Gómez, F., Moreno, J.C., Morla, C., 1997. Los bosques ibéricos. Una Interpret. Geobotánica Barc. Planeta 597.

Bogino, S., Bravo, F., 2009. Climate and intraannual density fluctuations in Pinus pinaster subsp. mesogeensis in Spanish woodlands. Can. J. For. Res. 39: 1557-1565.

Bogino, S., Fernández Nieto, M.J., Bravo, F., 2009. Climate effect on radial growth of Pinus sylvestris at its southern and western distribution limits. Silva Fenn. 43: 609-623.

Bogino, S.M., Bravo, F., 2008. Growth response of Pinus pinaster Ait. to climatic variables in central Spanish forests. Ann. For. Sci. 65: 506-506. 
Bouriaud, O., Leban, J.-M., Bert, D., Deleuze, C., 2005. Intra-annual variations in climate influence growth and wood density of Norway spruce. Tree Physiol. 25: 651-660.

Bradley, R.S., Diaz, H.F., Eischeid, J.K., Jones, P.D., Kelly, P.M., Goodess, C.M., 1987. Precipitation fluctuations over Northern Hemisphere land areas since the mid-19th century. Science 237: 171-175.

Bréda, N., Huc, R., Granier, A., Dreyer, E., 2006. Temperate forest trees and stands under severe drought: a review of ecophysiological responses, adaptation processes and long-term consequences. Ann. For. Sci. 63: 625-644.

Briffa, K.R., Osborn, T.J., Schweingruber, F.H., 2004. Large-scale temperature inferences from tree rings: a review. Glob. Planet. Change: 11-26.

Briffa, K.R., Osborn, T.J., Schweingruber, F.H., Harris, I.C., Jones, P.D., Shiyatov, S.G., Vaganov, E.A., 2001. Low-frequency temperature variations from a northern tree ring density network. J. Geophys. Res. 106: 2929-2941.

Bunn, A.G., 2008. A dendrochronology program library in R (dplR). Dendrochronologia 26: $115-124$.

Büntgen, U., Frank, D., Trouet, V., Esper, J., 2010. Diverse climate sensitivity of Mediterranean tree-ring width and density. Trees 24: 261-273.

Camarero, J.J., Olano, J.M., Parras, A., 2010. Plastic bimodal xylogenesis in conifers from continental Mediterranean climates. New Phytol. 185: 471-480.

Campelo, F., Nabais, C., Freitas, H., Gutiérrez, E., 2007. Climatic significance of tree-ring width and intra-annual density fluctuations in Pinus pinea from a dry Mediterranean area in Portugal. Ann. For. Sci. 64: 229-238.

Campelo, F., Vieira, J., Nabais, C., 2013. Tree-ring growth and intra-annual density fluctuations of Pinus pinaster responses to climate: does size matter? Trees 27: 763-772. 
Chambel, M.R., Climent, J., Alía, R., 2007. Divergence among species and populations of Mediterranean pines in biomass allocation of seedlings grown under two watering regimes. Ann. For. Sci. 64: 87-97.

Cherubini, P., Gartner, B.L., Tognetti, R., Bräker, O.U., Schoch, W., Innes, J.L., 2003. Identification, measurement and interpretation of tree rings in woody species from mediterranean climates. Biol. Rev. 78: 119-148.

Conkey, L.E., 1979. Response of tree-ring density to climate in Maine, USA. Tree-Ring Bull. 39: 29-38.

Cook, E.R., Holmes, R.L., 1984. Program ARSTAN users manual. Lab. Tree-Ring Res. Univ. Ariz. Tucson 15.

Cotillas, M., Sabaté, S., Gracia, C., Espelta, J.M., 2009. Growth response of mixed mediterranean oak coppices to rainfall reduction: Could selective thinning have any influence on it? For. Ecol. Manag. 258: 1677-1683.

D’Arrigo, R.D., Jacoby, G.C., Free, R.M., 1992. Tree-ring width and maximum latewood density at the North American tree line: parameters of climatic change. Can. J. For. Res. 22: 1290-1296.

De Luis, M., Gričar, J., Čufar, K., Raventós, J., 2007. Seasonal dynamics of wood formation in Pinus halepensis from dry and semi-arid ecosystems in Spain. Iawa J. Int. Assoc. Wood Anat. 28, 389-404.

Dean, T.J., Long, J.N., 1986. Validity of Constant-stress and Elastic-instability Principles of Stem Formation in Pinus contorta and Trifolium pratense. Ann. Bot. 58: 833-840.

Decoux, V., Varcin, Eliane, Leban, J.-M., 2004. Relationships between the intra-ring wood density assessed by X-ray densitometry and optical anatomical measurements in conifers. Consequences for the cell wall apparent density determination. Ann. For. Sci. 61: 251-262.

Deslauriers, A., Rossi, S., Anfodillo, T., 2007. Dendrometer and intra-annual tree growth: What kind of information can be inferred? Dendrochronologia 25: 113-124. 
DGCN, 2002. Plan Forestal Español, Ministerio de Medio Ambiente. ed.

Diaz, H.F., Bradley, R.S., Eischeid, J.K., 1989. Precipitation fluctuations over global land areas since the late 1800's. J. Geophys. Res. Atmospheres 94: 1195-1210.

Eilmann, B., Zweifel, R., Buchmann, N., Fonti, P., Rigling, A., 2009. Drought-induced adaptation of the xylem in Scots pine and pubescent oak. Tree Physiol. 29: 1011-1020.

Fritts, H.C., 2001. Tree rings and climate. The Blackburn press, London

Fritts, H.C., Swetnam, T.W., 1989. Dendroecology: A Tool for Evaluating. Adv. Ecol. Res. $19,111$.

Gea-Izquierdo, G., Martín-Benito, D., Cherubini, P., Cañellas, I., 2009. Climate-growth variability in Quercus ilex L. west Iberian open woodlands of different stand density. Ann. For. Sci. 66: 802-802.

Gilmore, A.R., 1968. Geographic variations in specific gravity of white pine and red pine in Illinois. Prod J 18: 49-51.

Granier, A., Bréda, N., Biron, P., Villette, S., 1999. A lumped water balance model to evaluate duration and intensity of drought constraints in forest stands. Ecol. Model. 116: 269-283.

Grissino-Mayer, H.D., 2001. Evaluating Crossdating Accuracy: A Manual and Tutorial for the Computer Program COFECHA [WWW Document]. URL http://arizona.openrepository.com/arizona/handle/10150/251654 (accessed 7.1.13).

Gutiérrez, E., Campelo, F., Camarero, J.J., Ribas, M., Muntán, E., Nabais, C., Freitas, H., 2011. Climate controls act at different scales on the seasonal pattern of Quercus ilex L. stem radial increments in NE Spain. Trees 25: 637-646.

Hair, J.F., Black, W.C., Babin, B., Anderson, R.E., Tatham, R.L., 1998. Multivariate data analysis. Prentice-Hall London. 
Holmes, R.L., 1992. Dendrochronology program library. Lab. Tree-Ring Res. Univ. Ariz. Tucson.

Horacek, P., Slezingerova, J., Gandelova, L., 1999. Effects of environment on the xylogenesis of Norway spruce (Picea abies [L.] Karst.). 33-53.

Hosmer, D.W., Lemeshow, S., Sturdivant, R.X., 2013. Applied Logistic Regression. John Wiley \& Sons.

Houghton, J.T., Ding, Y., Griggs, D.J., Noguer, M., Van der Linden, P.J., Dai, X., Maskell, K., Johnson, C.A., 2001. IPCC, 2001: Climate Change 2001: The Scientific Basis. Contribution of Working Group I to the Third Assessment Report of the Intergovernmental Panel on Climate Change. Camb. United Kingd. New York Usa Camb. Univ. Press 881, 9.

Kaennel, M., Schweingruber, F.H., 1995. Multilingual glossary of dendrochronology. 467 pp.

Keeland, B.D., Sharitz, R.R., 1993. Accuracy of tree growth measurements using dendrometer bands. Can. J. For. Res. 23: 2454-2457.

Kellomäki, S., Ikonen, V.-P., Peltola, H., Kolström, T., 1999. Modelling the structural growth of Scots pine with implications for wood quality. Ecol. Model. 122: 117-134.

Klein Tank, A.M.G., Können, G.P., 2003. Trends in Indices of Daily Temperature and Precipitation Extremes in Europe, 1946-99. J. Clim. 16: 3665-3680.

Kramer, P.J., 1964. The role of water in wood formation, In Zimmermann M.H. (ed.), The formation of wood in forest trees. ed. Academic Press, New York, London.

Laird, N.M., Ware, J.H., 1982. Random-Effects Models for Longitudinal Data. Biometrics $38,963$.

Lavorel, S., Canadell, J., Rambal, S., Terradas, J., 1998. Mediterranean terrestrial ecosystems: research priorities on global change effects. Glob. Ecol. Biogeogr. Lett. 7: $157-166$. 
Lev-Yadun, S., 2000. Wood structure and the ecology of annual growth ring formation in Pinus halepensis and P. brutia. Ecol. Biogeogr. Manag. Pinus halepensis P. Brutia For. Ecosyst. Mediterr. Basin”ne’eman G Trabaud Eds Backhuys Leiden Neth. 67-78.

Linares, J.C., Camarero, J.J., Carreira, J.A., 2009. Plastic responses of Abies pinsapo xylogenesis to drought and competition. Tree Physiol. 29: 1525-1536.

Liphschitz, N., Lev-Yadun, S., Rosen, E., Waisel, Y., 1984. The annual rhythm of activity of the lateral meristems (cambium and phellogen) in Pinus halepensis Mill. and Pinus pinea L. Iawa Bull 5: 263-274.

Maheras, P., 1988. Changes in precipitation conditions in the western mediterranean over the last century. J. Clim. 8: 179-189.

Mäkinen, H., Nöjd, P., Saranpää, P., 2003. Seasonal changes in stem radius and production of new tracheids in Norway spruce. Tree Physiol. 23: 959-968.

Martín-Benito, D., Cherubini, P., Río, M. del, Cañellas, I., 2008. Growth response to climate and drought in Pinus nigra Arn. trees of different crown classes. Trees 22: 363-373.

Martínez-Vilalta, J., Piñol, J., 2002. Drought-induced mortality and hydraulic architecture in pine populations of the NE Iberian Peninsula. For. Ecol. Manag. 161: 247-256.

Martrat, B., Grimalt, J.O., Lopez-Martinez, C., Cacho, I., Sierro, F.J., Flores, J.A., Zahn, R., Canals, M., Curtis, J.H., Hodell, D.A., 2004. Abrupt Temperature Changes in the Western Mediterranean over the Past 250,000 Years. Science 306: 1762-1765.

Meng, S.X., Lieffers, V.J., Reid, D.E.B., Rudnicki, M., Silins, U., Jin, M., 2006. Reducing stem bending increases the height growth of tall pines. J. Exp. Bot. 57: 3175-3182.

Misson, L., Nicault, A., Guiot, J., 2003. Effects of different thinning intensities on drought response in Norway spruce (Picea abies (L.) Karst.). For. Ecol. Manag. 183: 47-60.

Mitrakos, K.A., 1980. A theory for Mediterranean plant life. Acta Oecol. 1: 245-252. 
Montero, G., Cañellas, I., Ruiz-Peinado, R., 2001. Growth and Yield Models for Pinus halepensis Mill. Investig. Agrar. Sist. Recur. For. 10: 179-201.

Moreno, G., Cubera, E., 2008b. Impact of stand density on water status and leaf gas exchange in Quercus ilex. For. Ecol. Manag. 254: 74-84.

Mothe, F., Duchanois, G., Leban, J.-M., Nepveu, G., 1998. Analyse microdensitométrique appliquée au bois: une méthode de traitement des données aboutissant B la description synthétique et homogène des profils de cerne (programme CERD). Ann. For. Sci. 55: 301315.

Nicolás, A., Gandullo, J.M., 1967. Ecología de los pinares españoles: Pinus pinaster Ait. Ministerio de Agricultura, Instituto Forestal de Investigaciones y Experiencias.

Novak, K., Luís, M. de, Raventós, J., Čufar, K., 2013. Climatic signals in tree-ring widths and wood structure of Pinus halepensis in contrasted environmental conditions. Trees 1-10.

Olivar, J., Bogino, S., Spiecker, H., Bravo, F., 2012. Climate impact on growth dynamic and intra-annual density fluctuations in Aleppo pine (Pinus halepensis) trees of different crown classes. Dendrochronologia 30: 35-47.

Orwig, D.A., Abrams, M.D., 1997. Variation in radial growth responses to drought among species, site, and canopy strata. Trees 11: 474-484.

Osborn, T.J., Briffa, K.R., Jones, P.D., 1997. Adjusting variance for sample size in treering chronologies and other regional mean timeseries. Dendrochronologia 15: 89-99.

Papadopoulos, A.M., Tolica, K., Pantera, A., Maheras, P., 2009. Investigation of the annual variability of the Aleppo pine tree-ring width: the relationship with the climatic conditions in the Attica basin. Glob. Nest J. 11: 583-592.

Parker, M.L., Henoch, W.E.S., 1971. The use of Engelmann spruce latewood density for dendrochronological purposes. Can. J. For. Res. 1: 90-98.

Parry, M.L., Canziani, O.F., Palutikof, J., van der Linden, P., 2007. Climate Change 2007: Impacts, Adaptation and Vulnerability: Working Group II Contribution to the Fourth 
Assessment Report of the IPCC Intergovernmental Panel on Climate Change. Cambridge University Press.

Pasho, E., Camarero, J.J., Vicente-Serrano, S.M., 2012. Climatic impacts and drought control of radial growth and seasonal wood formation in Pinus halepensis. Trees 26: 18751886.

Peet, R.K., Christensen, N.L., 1987. Competition and Tree Death. BioScience 37: 586-595.

Peñuelas J., Lloret F., Montoya R., 2001. Severe Drought Effects on Mediterranean Woody Flora in Spain. For. Sci. 47: 214-218.

Persson, B., Persson, A., Ståhl, E.G., Karlmats, U., 1995. Wood quality of Pinus sylvestris progenies at various spacings. For. Ecol. Manag. 76: 127-138.

Petit, R.J., Hampe, A., Cheddadi, R., 2005. Climate Changes and Tree Phylogeography in the Mediterranean. Taxon 54: 877.

Quezel, P., 1986. Les pins du groupe «Halepensis» ecologie, végétation, ecophysiologie. Options Méditerranéennes 1: 11-23.

R Development Core team, 2011. A Language and Environment for Statistical Computing. R Found. Stat. Comput. Vienna Austria.

Rathgeber, C.B.K., Decoux, V., Leban, J.-M., 2006. Linking intra-tree-ring wood density variations and tracheid anatomical characteristics in Douglas fir (Pseudotsuga menziesii (Mirb.) Franco). Ann. For. Sci. 63: 699-706.

Rathgeber, C.B.K., Misson, L., Nicault, A., Guiot, J., 2005. Bioclimatic model of tree radial growth: application to the French Mediterranean Aleppo pine forests. Trees 19: 162176.

Raventós, J., De Luís, M., Gras, M.J., Čufar, K., Gonzáles-Hidalgo, J.-C., Bonet, A., Sánchez, J.R., 2001. Growth of Pinus pinea and Pinus halepensis as affected by dryness, marine spray and land use changes in a Mediterranean semiarid ecosystem. Dendrochronologia 9: 211-220. 
Richter, K., Eckstein, D., Holmes, R.L., 1991. The Dendrochronological Signal of Pine Trees (Pinus Spp.) in Spain. Tree-ring Bulletin 51: 1-13.

Rigling, A., Waldner, P.O., Forster, T., Bräker, O.U., Pouttu, A., 2001. Ecological interpretation of tree-ring width and intra-annual density fluctuations in Pinus sylvestris on dry sites in the central Alps and Siberia. Can. J. For. Res. 31: 18-31.

Roderick, M.L., Berry, S.L., 2001. Linking wood density with tree growth and environment: a theoretical analysis based on the motion of water. New Phytol. 149: 473485.

Rossi, S., Deslauriers, A., Anfodillo, T., Carrer, M., 2008. Age-dependent xylogenesis in timberline conifers. New Phytol. 177: 199-208.

Rossi, S., Deslauriers, A., Anfodillo, T., Morin, H., Saracino, A., Motta, R., Borghetti, M., 2006. Conifers in cold environments synchronize maximum growth rate of tree-ring formation with day length. New Phytol. 170: 301-310.

Rozas, V., García-González, I., Zas, R., 2011. Climatic control of intra-annual wood density fluctuations of Pinus pinaster in NW Spain. Trees 25: 443-453.

Sass, U., Eckstein, D., 1995. The variability of vessel size in beech (Fagus sylvatica L.) and its ecophysiological interpretation. Trees 9: 247-252.

Schmitt, U., Möller, R., Eckstein, D., 2000. Seasonal wood formation dynamics of beech (Fagus sylvatica L.) and black locust (Robinia pseudoacacia L.) as determined by the “pinning” technique. Angew. Bot. 74: 10-16.

Schweingruber, F.H., 1993. Trees and wood in dendrochronology: morphological, anatomical, and tree-ring analytical characteristics of trees frequently used in dendrochronology. vii + $402 \mathrm{pp}$.

Schweingruber, F.H., 1996. Tree rings and environment: dendroecology. 609 pp.

Schweingruber, F.H., Fritts, H.C., Bräker, O.U., Drew, L.G., Schär, E., 1978. The X-ray technique as applied to dendroclimatology. Tree-Ring Bull. 38: 61-91. 
Sheppard, P.R., 2010. Dendroclimatology: extracting climate from trees. Wiley Interdiscip. Rev. Clim. Change 1: 343-352.

Specht, R.L., 1981. Mediterranean-type shrublands, di Castri,Francesco; Goodall, David W.; Specht,. ed. Elsevier Scientific Pub. Co.: distributors for the United States and Canada, Elsevier North-Holland.

Spiecker, H., 2003. Silvicultural management in maintaining biodiversity and resistance of forests in Europe-temperate zone. J. Environ. Manage. 67: 55-65.

Spiecker, H., Mielikäinen, K., Köhl, M., Skovsgaard, J.P., 1996. Growth trends in European forests: studies from 12 countries. European Forest Institute Research Report. 5. Springer, Heidelberg.

Stokes, M.A., Smiley, T.L., 1996. An Introduction to Tree-Ring Dating. University of Arizona Press.

Tardif, J., Camarero, J.J., Ribas, M., Gutiérrez, E., 2003. Spatiotemporal variability in tree growth in the central pyrenees: Climatic and site influences. Ecol. Monogr. 73: 241-257.

Tessier, L., Guibal, F., Schweingruber, F.H., 1997. Research strategies in dendroecology and dendroclimatology in mountain environments. Clim. Change 36: 499-517.

Valbuena, P., Bravo, F., 2008. Stand Density Management Diagrams for two Mediterranean pine species in Eastern Spain. For. Syst. 17: 97-104.

Van der Maaten, E., van der Maaten-Theunissen, M., Spiecker, H., 2012. Temporally resolved intra-annual wood density variations in European beech (Fagus sylvatica L.) as affected by climate and aspect. Ann. For. Res. 55: 113-124.

Van Lear, D.H., Kapeluck, P.R., 1995. Above- and below-stump biomass and nutrient content of a mature loblolly pine plantation. Can. J. For. Res. 25: 361-367.

Verdú, M., Dávila, P., García-Fayos, P., Flores-Hernández, N., Valiente-Banuet, A., 2003. "Convergent" traits of mediterranean woody plants belong to pre-mediterranean lineages. Biol. J. Linn. Soc. 78: 415-427. 
Vieira, J., Campelo, F., Nabais, C., 2009. Age-dependent responses of tree-ring growth and intra-annual density fluctuations of Pinus pinaster to Mediterranean climate. Trees 23: 257265.

Vieira, J., Campelo, F., Nabais, C., 2010. Intra-annual density fluctuations of Pinus pinaster are a record of climatic changes in the western Mediterranean region. Can. J. For. Res. 40: 1567-1575.

Villalba, R., Veblen, T.T., 1996. A tree-ring record of dry spring-wet summer events in the forest-steppe ecotone, northern Patagonia, Argentina. Tree Rings Environ. Humanity 107116.

Wigley, T.M.L., Briffa, K.R., Jones, P.D., 1984. On the Average Value of Correlated Time Series, with Applications in Dendroclimatology and Hydrometeorology. J. Clim. Appl. Meteorol. 23: 201-213.

Wimmer, R., Downes, G.M., 2003. Temporal variation of the ring width-wood density relationship in Norway spruce grown under two levels of anthropogenic disturbance. Iawa J. 24: 53-62.

Wimmer, R., Strumia, G., Holawe, F., 2000. Use of false rings in Austrian pine to reconstruct early growing season precipitation. Can. J. For. Res. 30: 1691-1697.

Wodzicki, T.J., 1971. Mechanism of Xylem Differentiation in Pinus silvestris L. J. Exp. Bot. 22: 670-687.

Xoplaki, E., Luterbache, J., Gonzalez-Rouco, J.F., 2006. Mediterranean summer temperature and winter precipitation, large scale dynamics, trends. Il Nuovo Cimento C 29: 45-54.

Yasue, K., Funada, R., Kobayashi, O., Ohtani, J., 2000. The effects of tracheid dimensions on variations in maximum density of Picea glehnii and relationships to climatic factors. Trees 14: 223-229. 
Zuur, A.F., Ieno, E.N., Walker, N.J., Saveliev, A.A., Smith, G.M., 2009. Mixed Effects Models and Extensions in Ecology with R. Springer.

Zweifel, R., Item, H., Häsler, R., 2001. Link between diurnal stem radius changes and tree water relations. Tree Physiol. 21: 869-877. 


\section{Studies}

Study I: Climate impact on growth dynamic and intra-annual density fluctuations in Aleppo pine (Pinus halepensis) trees of different crown classes

Study II: Changes in climate-growth relationships and IADF formation over time in Mediterranean pine species (Pinus halepensis, $P$. pinaster and $P$. sylvestris) in Spain

Study III: Effects of thinning on growth dynamics and growthclimate relationships in Aleppo pine (Pinus halepensis) trees of different crown classes

Study IV: Climate impact on wood density in Pinus halepensis, Pinus pinaster and Pinus sylvestris 
Olivar (2013) 


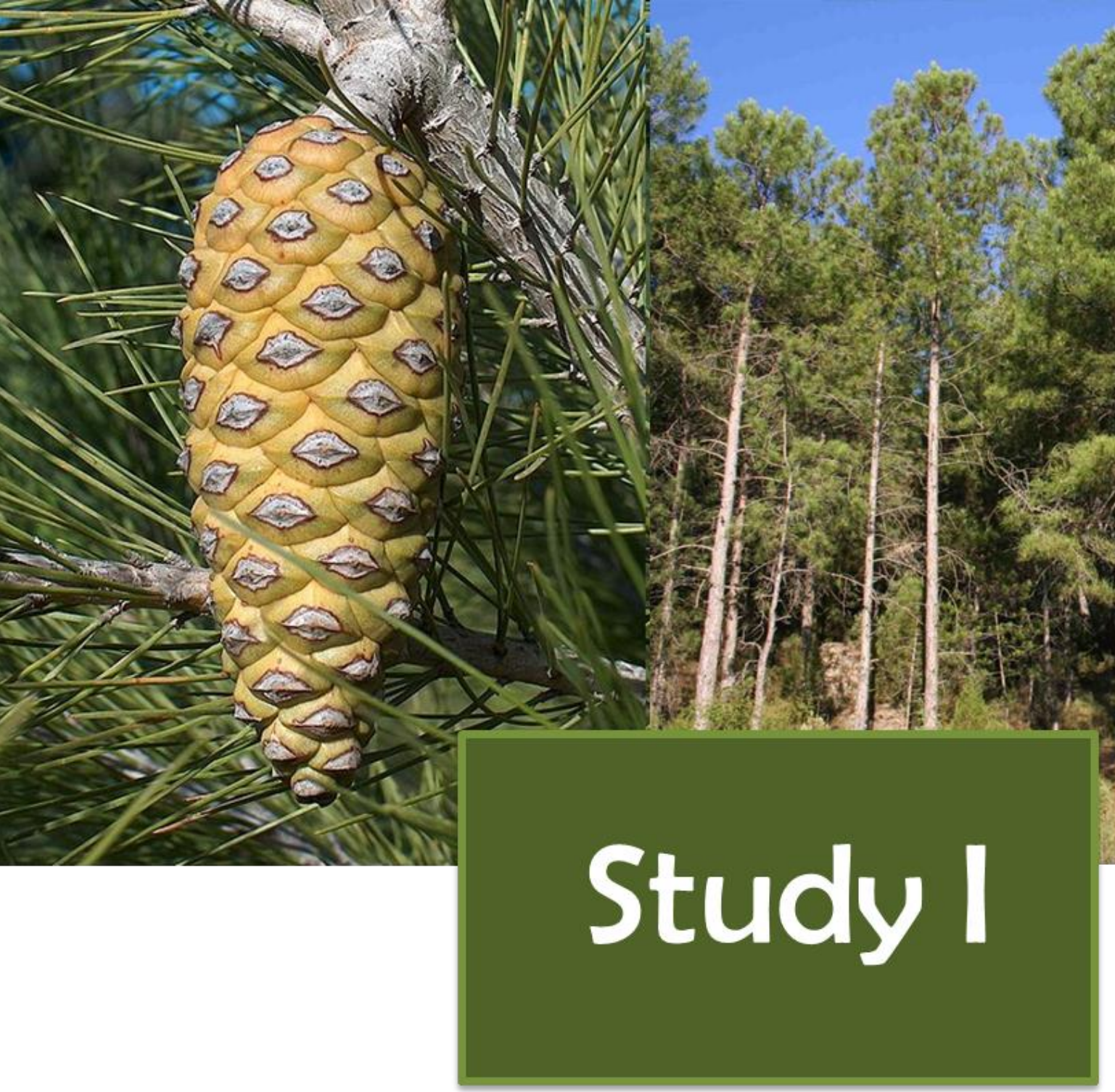

\section{Climate impact on growth dynamic and intra- annual density fluctuations in Aleppo pine (Pinus halepensis) trees of different crown classes}

* Olivar, J., Bogino, S., Spiecker, H., Bravo, F., 2012. Climate impact on growth dynamic and intra-annual density fluctuations in Aleppo pine (Pinus halepensis) trees of different crown classes. Dendrochronologia 30 Issue 1: 35-47. 
Olivar (2013) 


\title{
Climate impact on growth dynamic and intra-annual density fluctuations in Aleppo pine (Pinus halepensis) trees of different crown classes
}

\author{
Jorge Olivar ${ }^{1,2}$, Stella Bogino ${ }^{3}$, Heinrich Spiecker ${ }^{2}$, Felipe Bravo ${ }^{1}$ \\ ${ }^{1}$ Sustainable Forest Management Research Institute University of Valladolid-INIA. Avda. de Madrid 57, \\ 34004, Palencia (Spain) \\ ${ }^{2}$ Institute of Forest Growth, Albert-Ludwigs-Universität Freiburg. Tennenbacherstr. 4, D-79106 Freiburg \\ (Germany) \\ ${ }_{3}^{3}$ Departamento de Ciencias Agropecuarias. Facultad de Ingeniería y Ciencias Económico-Sociales. \\ Universidad Nacional de San Luis. Avda. 25 de Mayo 384, 5730 Villa Mercedes, San Luis (Argentina)
}

\begin{abstract}
Mediterranean environments are of special interest for the study of the relationships between climate, growth and anatomic features. Dendrochronological techniques were applied at eight sampling sites that were selected throughout the natural distribution area of Pinus halepensis in Spain. The objectives of this paper were: i) to identify relationships between radial growth and climate for different crown classes of Aleppo pine (Pinus halepensis Mill.) ii) to quantify the presence of intra-annual density fluctuations (IADFs) according to crown class and cambial age and iii) to establish the relationships between IADFs and climate. In the more mesic sites, dominant trees showed higher climate sensitivity than suppressed trees, while in the more xeric sites suppressed trees showed higher sensitivity than dominant trees. Tree-ring growth of both crown classes correlated positively with precipitation during and prior to the growing season. IADFs were more frequent in young than in old stands without differences between crown classes. Precipitation in April and December was positively correlated to the occurrence of IADFs, while precipitation in July correlated negatively. A higher frequency in IADFs occurred in the last fifty years, which coincides with the increase in drought events in Spain
\end{abstract}

\section{Key words}

Mediterranean climate, dendrochronology, Spain, tree-ring growth. 


\section{Introduction}

Tree radial-growth models are valuable for simulating the impacts of climate change on the future growth of forest species. Understanding how forest growth responds to climate is a key element for a deeper knowledge of forest dynamics in a changing environment. Trees growing in extreme conditions respond strongly to climate variations. Mediterranean regions, as transitional climate zones between arid and humid regions of the world, are areas where climatic changes may have the greatest effects (Lavorel et al., 1998).

Different Mediterranean pine species have been analysed to detect relationship between climatic trends and tree growth. Growth of pine species is positively correlated to precipitation in the Iberian Peninsula: Pinus pinea in southern Portugal (Campelo et al., 2007), Pinus pinaster in central Portugal (Vieira et al., 2009) and in central Spain (Bogino and Bravo, 2008), Pinus nigra in southeastern Spain (Martin-Benito et al., 2008) and Pinus sylvestris in its southern and western distribution threshold (Bogino et al., 2009). In southern Italy, growth rate of Pinus hapepensis is sensitive mainly to temperature variations during the wet season and to soil humidity variations during the dry season (Attolini et al., 1990). In France, Rathgeber et al. (2005) concluded that Pinus halepensis growth is mainly controlled by soil water availability during the growing season. In Greece, the growth of Aleppo pine was related positively with the winter and spring precipitations and negatively with the temperatures of the spring months (Papadopoulos et al., 2008).

Wood anatomical features in tree rings have been interpreted as indicators of environmental change (see for instance Briffa et al., 2003). Species growing under Mediterranean climate, with summer droughts and high inter-annual variability in precipitation and temperature, commonly show special anatomical characteristics in tree rings (Schweingruber, 1993). Intra-annual density fluctuations (IADFs) are defined as "a layer of cells within a tree ring identified by different shape, size and wall thickness" (Kaennel and Schweingruber, 1995). Their inclusion of IADFs in dendrochronological studies allows detailed analysis of climatic events within the growing season. Different studies of pine species showed a good correlation between IADF formation and climate in the Mediterranean area. IADFs were mainly correlated with precipitation in autumn in $P$. pinaster in Portugal (Vieira et al., 
2009) and with precipitation in late winter and spring and higher temperatures in central Spain (Bogino and Bravo, 2009). IADFs were caused by precipitation events early in summer following a water deficit early in the growing season in Pinus pinea in southern Portugal (Campelo et al., 2007). Until now, the information about the impact of climate on IADFs of Pinus halepensis is scarce.

The Aleppo Pine (Pinus halepensis Mill.) is a native pine of the Mediterranean region, where it is one of the main species in the present landscape. Therefore, the study of the impact of climatic variables (temperature and precipitation) on its radial growth becomes of major interest. The objectives of the present study were: i) to identify relationships between radial growth and climate for different crown classes of Aleppo pine (P. halepensis Mill.) ii) to quantify the presence of intra-annual density fluctuations (IADFs) according to crown class and cambial age and iii) to establish the relationships between IADFs and climate.

\section{Materials and Methods}

\section{Sites}

Eight sampling sites were selected throughout the natural distribution area of Pinus halepensis in Spain (Fig. 1; Table 1).

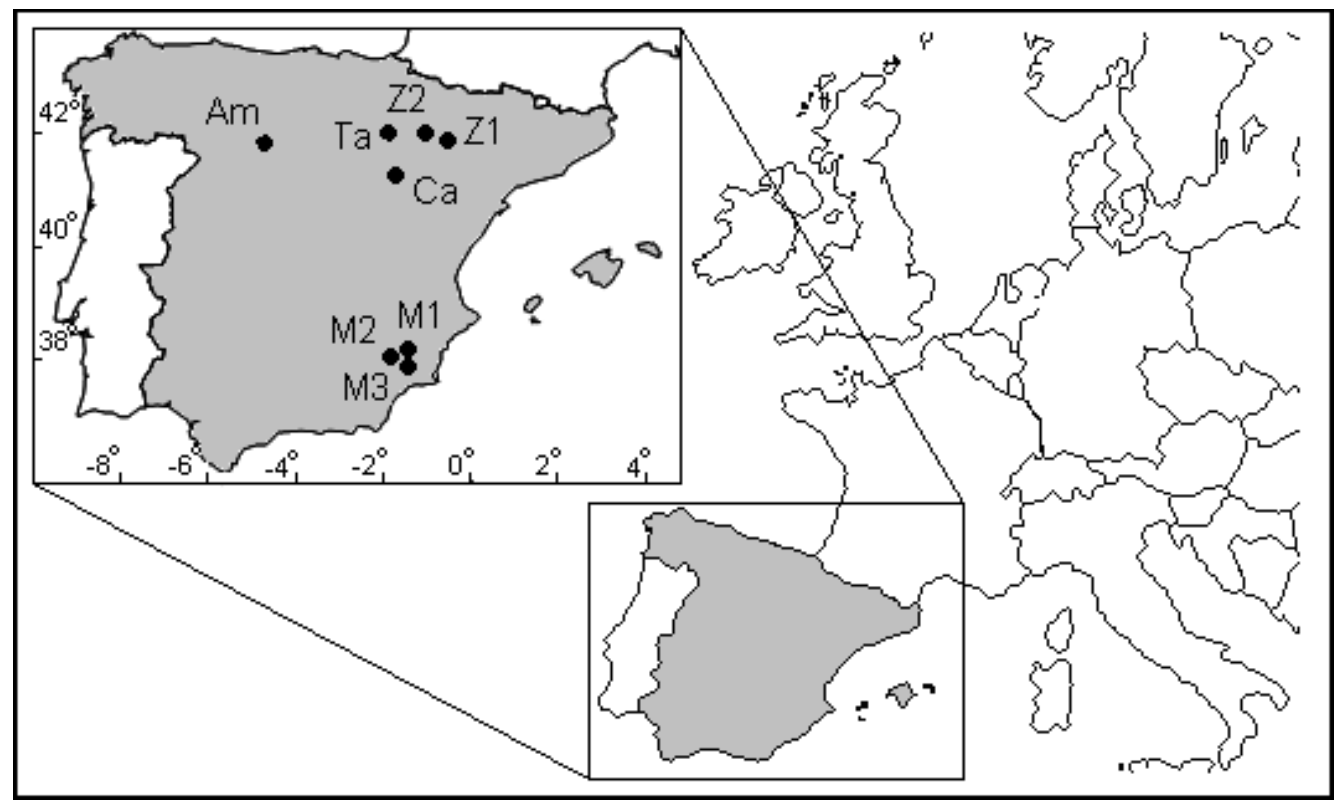

Fig. 1: Study areas of Pinus halepensis in Spain. 
The site index, a relative measure of forest site quality based on the height of the dominant trees at a specific age, was determined by using site index curves. The site index was defined as the top height (m) at age 80 (Montero et al., 2001).

Table 1: Sampling sites and meteorological stations.

\begin{tabular}{ccccccccc}
\hline Site & Location & Latitude & Longitude & $\begin{array}{c}\text { Altitude } \\
(\mathbf{m})\end{array}$ & $\begin{array}{c}\text { Site } \\
\text { Index }\end{array}$ & Met. Station & Longitude & Latitude \\
\hline Am & Palencia & $41^{\circ} 51^{\prime} 36^{\prime \prime}$ & $4^{\circ} 45^{\prime} 36^{\prime \prime}$ & 849 & Q17 & Palencia E.C.A & $42^{\circ} 00^{\prime} 30^{\prime \prime}$ & $4^{\circ} 33^{\prime} 27^{\prime \prime}$ \\
Ca & Aragón & $41^{\circ} 18^{\prime} 16^{\prime \prime}$ & $1^{\circ} 44^{\prime} 52^{\prime \prime}$ & 976 & Q14 & Calatayud aguas & $41^{\circ} 19^{\prime} 51^{\prime \prime}$ & $1^{\circ} 38^{\prime} 49^{\prime \prime}$ \\
Ta & Aragón & $41^{\circ} 59^{\prime} 31^{\prime \prime}$ & $1^{\circ} 50^{\prime} 09^{\prime \prime}$ & 695 & Q20 & Tarazona & $41^{\circ} 54^{\prime} 28^{\prime \prime}$ & $1^{\circ} 43^{\prime} 54^{\prime \prime}$ \\
Za1 & Aragón & $41^{\circ} 48^{\prime} 58^{\prime \prime}$ & $0^{\circ} 32^{\prime} 15^{\prime \prime}$ & 535 & Q11 & Sos del rey catolico & $42^{\circ} 29^{\prime} 34^{\prime \prime}$ & $1^{\circ} 12^{\prime} 52^{\prime \prime}$ \\
Za2 & Aragón & $41^{\circ} 56^{\prime} 04^{\prime \prime}$ & $0^{\circ} 56^{\prime} 25^{\prime \prime}$ & 706 & Q11 & Sos del rey catolico & $42^{\circ} 29^{\prime} 34^{\prime \prime}$ & $1^{\circ} 12^{\prime} 52^{\prime \prime}$ \\
M1 & Murcia & $37^{\circ} 52^{\prime} 51^{\prime \prime}$ & $1^{\circ} 30^{\prime} 36^{\prime \prime}$ & 811 & Q11 & Moratalla "benizar" & $38^{\circ} 16^{\prime} 25^{\prime \prime}$ & $1^{\circ} 58^{\prime} 59^{\prime \prime}$ \\
M2 & Murcia & $37^{\circ} 52^{\prime} 50^{\prime \prime}$ & $1^{\circ} 32^{\prime} 15^{\prime \prime}$ & 957 & Q20 & Moratalla "benizar" & $38^{\circ} 16^{\prime} 25^{\prime \prime}$ & $1^{\circ} 58^{\prime} 59^{\prime \prime}$ \\
M3 & Murcia & $37^{\circ} 51^{\prime} 13^{\prime \prime}$ & $1^{\circ} 32^{\prime} 34^{\prime \prime}$ & 1118 & Q17 & Moratalla "benizar" & $38^{\circ} 16^{\prime} 25^{\prime \prime}$ & $1^{\circ} 58^{\prime} 59^{\prime \prime}$ \\
\hline
\end{tabular}

\section{Chronologies}

Fifteen trees from each crown class (dominant and suppressed) were selected on each sampling site. Dominant trees were defined as those standing above all other trees in its vicinity and receiving full light from above, whereas suppressed trees were defined as those growing below the tree canopy. In sites $\mathrm{Za} 1$ and $\mathrm{Za} 2$ only dominant trees were sampled. Therefore, a total of fourteen tree-ring chronologies (eight dominant and six suppressed) were analysed. On each tree two cores were extracted at $1.30 \mathrm{~m}$ above ground. The increment cores were air dried and mounted on wooden supports and dated according to standard dendrochronological techniques (Stokes and Smiley, 1968). The preparation of the samples was done by use of the diamond flycutter (Kugler, F500). This machine was designed specifically for single point diamond flycutting of plan surfaces requiring an optical quality surface finish, precise flatness and exacting parallelism.

The v6.06P COFECHA program (Holmes, 2001; Grissino-Mayer, 2001; available at www.ltrr.arizona.edu) was applied to assess measurement and dating accuracy. This program calculates the Pearson correlation indices between the indexed tree-ring series and a master reference chronology in a series of consecutive, partially overlapped segments of a 
length specified by the user. Absolute dating is essential for any dendroclimatological study, and it is impossible to compare climatic variables in one specific year with tree-ring growth if the individual tree-ring series are not dated correctly. According to standard methods in dendrochronology trees exhibiting correlation values with the master chronology below 0.4 were excluded.

To eliminate biological trends in tree-ring series and to minimize growth variations that are not shared by most trees, the v6.05P ARSTAN program (Cook and Holmes, 1984; Holmes, 2001; available at www.ltrr.arizona.edu) was used. Standardization removes geometrical and ecological trends while preserving inter-annual high-frequency variations that are presumably related to climate. To obtain a master chronology at each study site and crown class, the standardized series were averaged.

The fourteen master chronologies were calculated separately to analyse differences in radial growth. Series from dominant and suppressed trees were averaged in two separate general chronologies. Chronology quality was evaluated using the mean sensitivity (MS), which is a measure of the mean relative changes between adjacent ring widths (Fritts, 2001); the signal-to-noise ratio (SNR), the proportion of the variability explained by climate or other casual factors divided by the residual or unexplained variability (Fritts and Swetnam, 1989); and the expressed population signal (EPS), which indicates the degree to which the particular sample chronology portrays a hypothetically perfect chronology (Wigley et al., 1984). The master chronologies were normalized by subtracting the mean and dividing by the standard deviation. Values far from cero mean higher reactions. The Normalized Difference Index was calculated by subtracting the normalized values of the suppressed trees to the normalized values of the dominant trees. Positive NDI values mean stronger reactions from dominant trees, while negative NDI values mean stronger reactions from suppressed trees.

\section{Relationships between climatic data and tree-ring widths}

Mean monthly air temperatures and total monthly precipitations were recorded at the closest meteorological stations (Agencia Estatal de Meteorología, Spain) (Table 1). Climatic data were grouped in climatic seasons: winter (December, January and February), 
spring (March, April and May), summer (June, July and August) and fall (September,

October and November). These seasonal data were regressed against ring-width indices in order to assess climate-growth relationships. DENDROCLIM 2002 (Biondi and Waikul, 2004) was applied to calculate correlation and response functions by bootstrapped error estimates (Guiot, 1991).

\section{Intra-annual density fluctuations}

The correctly dated cores were visually examined for IADFs. IADFs show a non-sharp transition in opposite to the annual rings boundary (Fritts, 2001). Because of the variability of IADFs tangentially and vertically within the tree ring along the stem the IADFs were only considered when present in both cores, in the same tree ring. As the number of samples changed over time, the relative frequency was calculated with the following formula [1]:

$$
[1] \mathrm{F}=\mathrm{n} / \mathrm{N}
$$

where $\mathrm{F}$ is the relative frequency of IADF in a particular year; $\mathrm{n}$ the number of trees that formed the IADF and $\mathrm{N}$ the total number of trees analysed. The bias in the frequency was assessed by calculating the stabilized IADF frequency (f), according to the formula of Osborn et al (1997) [2]:

$$
\text { [2] } \mathrm{f}=\mathrm{F}^{0.5}
$$

The nonlinear logistic equation form was chosen to model the probability of occurrence of IADFs [3]:

[3] $\mathrm{P}=\left(1.0+\mathrm{e}^{(-\mathrm{z})}\right)^{-1}$

where $\mathrm{P}$ is the probability of IADFs and $\mathrm{Z}=\mathrm{b} 0+\mathrm{b} 1(\mathrm{x} 1)+\mathrm{b} 2(\mathrm{x} 2)+\ldots \ldots+\mathrm{bk}(\mathrm{xk})+\varepsilon$; where $\mathrm{x} 1 ; \mathrm{x} 2 \ldots . . \mathrm{xk}$ are the climatic variables and $\mathrm{b} 0 ; \mathrm{b} 1 ; \mathrm{b} 2 \ldots . . \mathrm{bk}$ are unknown parameters of the model and $\varepsilon$ is a normal random error $\mathrm{N}(0,1)$; and $e$ is the exponential operator. The logistic equation can be formulated to accept a binary variable such as occurrence of IADFs, and the parameters can be estimated by maximum-likelihood methods. The resulting prediction is bounded by 0 and 1 . Monthly rainfall and mean monthly temperature 
were used as explanatory variables. The hydrological year was defined as a period of 12 months, from October of the previous year to September of the current growth year. A stepwise selection method was used to find the best model.

The alternative fits were evaluated on the basis of Akaike information criterion (AIC), the $2 * \log$ Likelihood, the area under the receiver operating characteristic (ROC) curve and the expected behavior - as indicated by the signs of the estimated parameters. ROC curve is displayed for the models and the area underneath was calculated as a value of the accuracy of the model. Value over 0.80 indicates an excellent discrimination (Hosmer and Lemeshow, 2000). This curve relies on false/true positive/negative tests, and the sensitivity is indicated by the proportion of correctly classified events and the specificity by the proportion of correctly classified non-events (Hair et al., 1998). This model was successfully used to estimate the probability of occurrence of IADFs in Pinus pinaster subsp. mesogenesis in Spain (Bogino and Bravo, 2009a). PROC LOGISTIC of SAS 9.1 (SAS Institute Inc. 2004) was used to fit the model. Samples were first grouped according to site location (Palencia, Aragón and Murcia), age (younger than 80 years and older than 80 years) and crown class (dominant and suppressed).

\section{Results}

\section{Chronologies}

The master chronologies of Pinus halepensis and the number of samples used at each sampling site are shown in Fig. 2. 

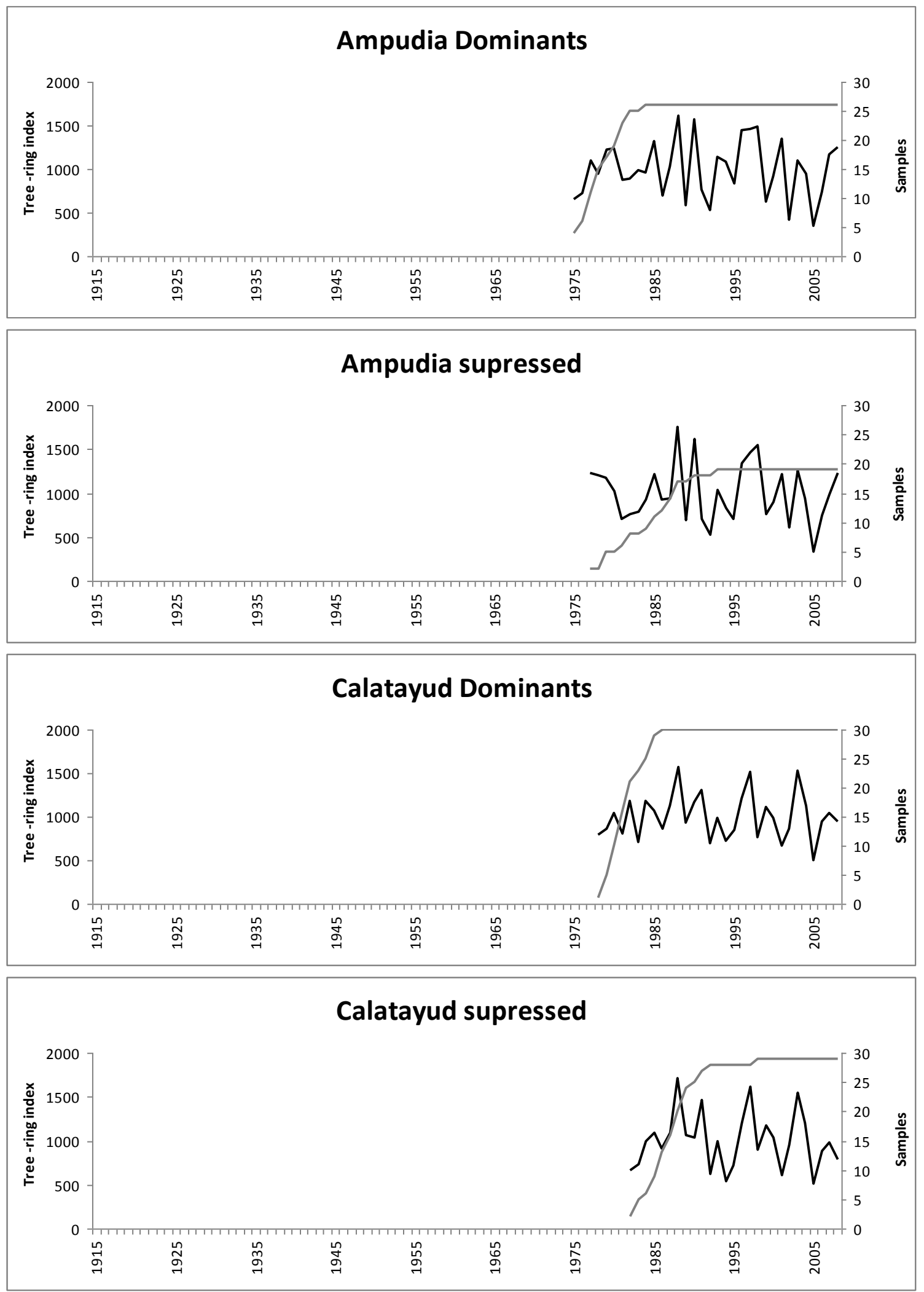

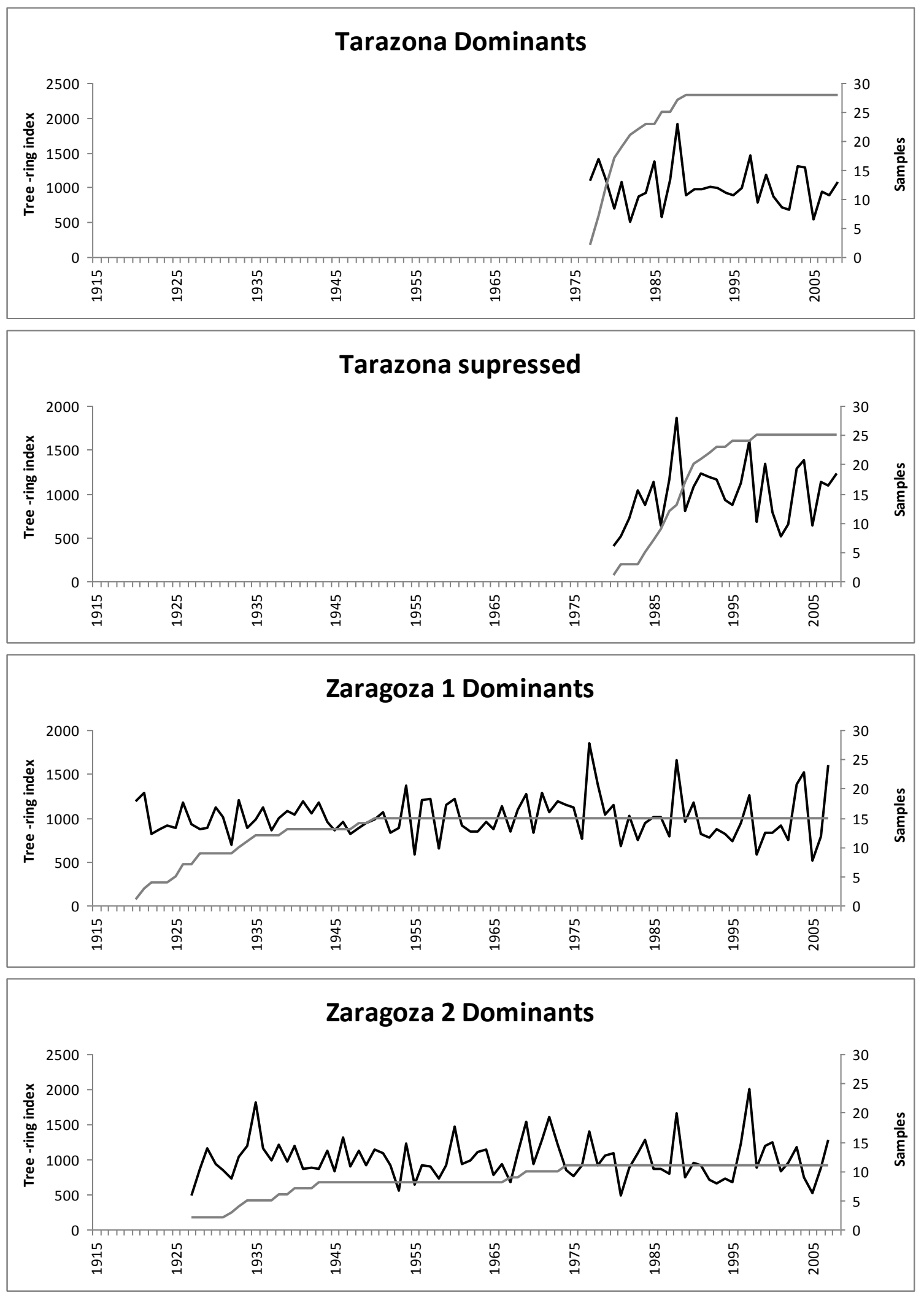

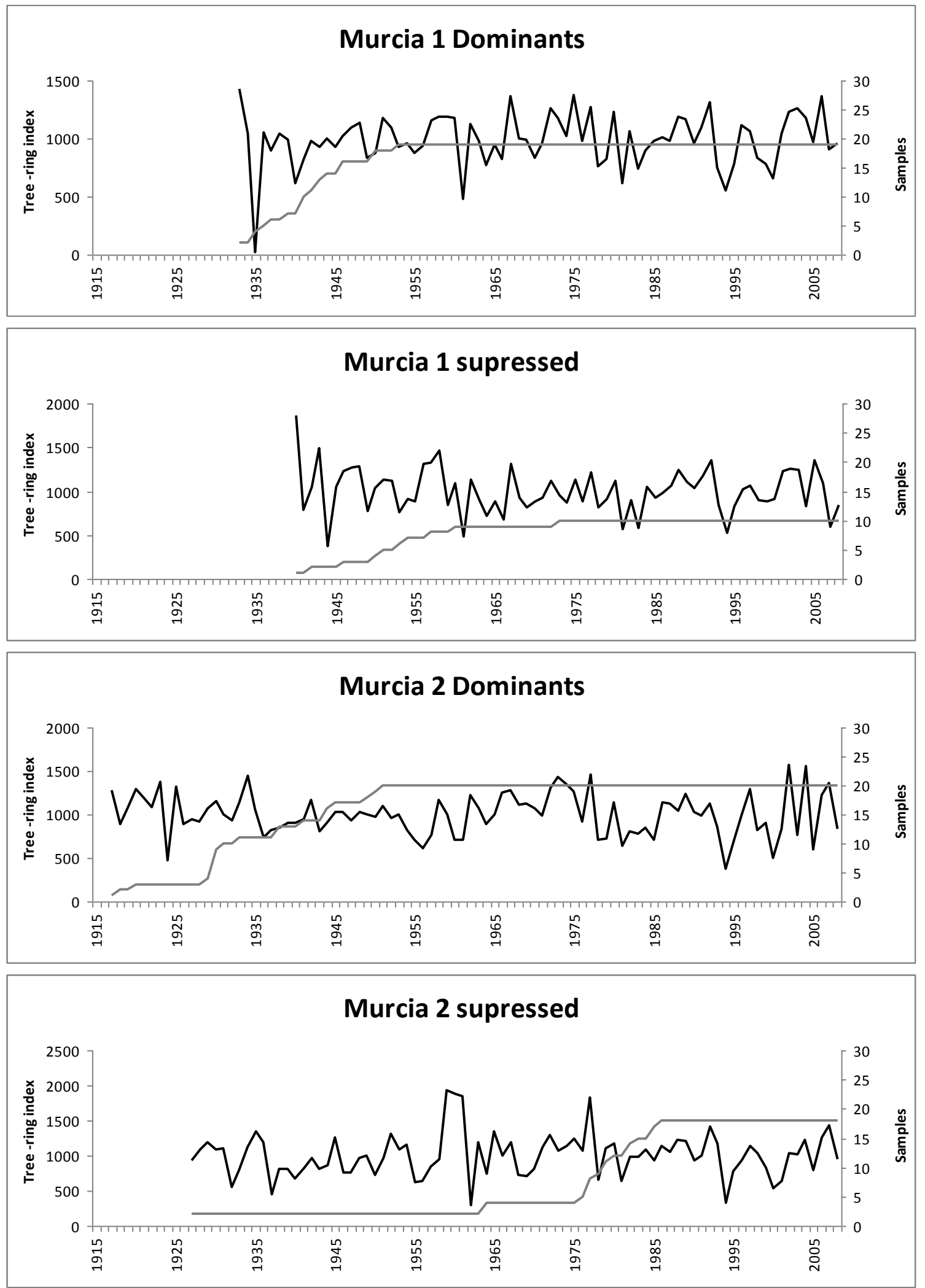

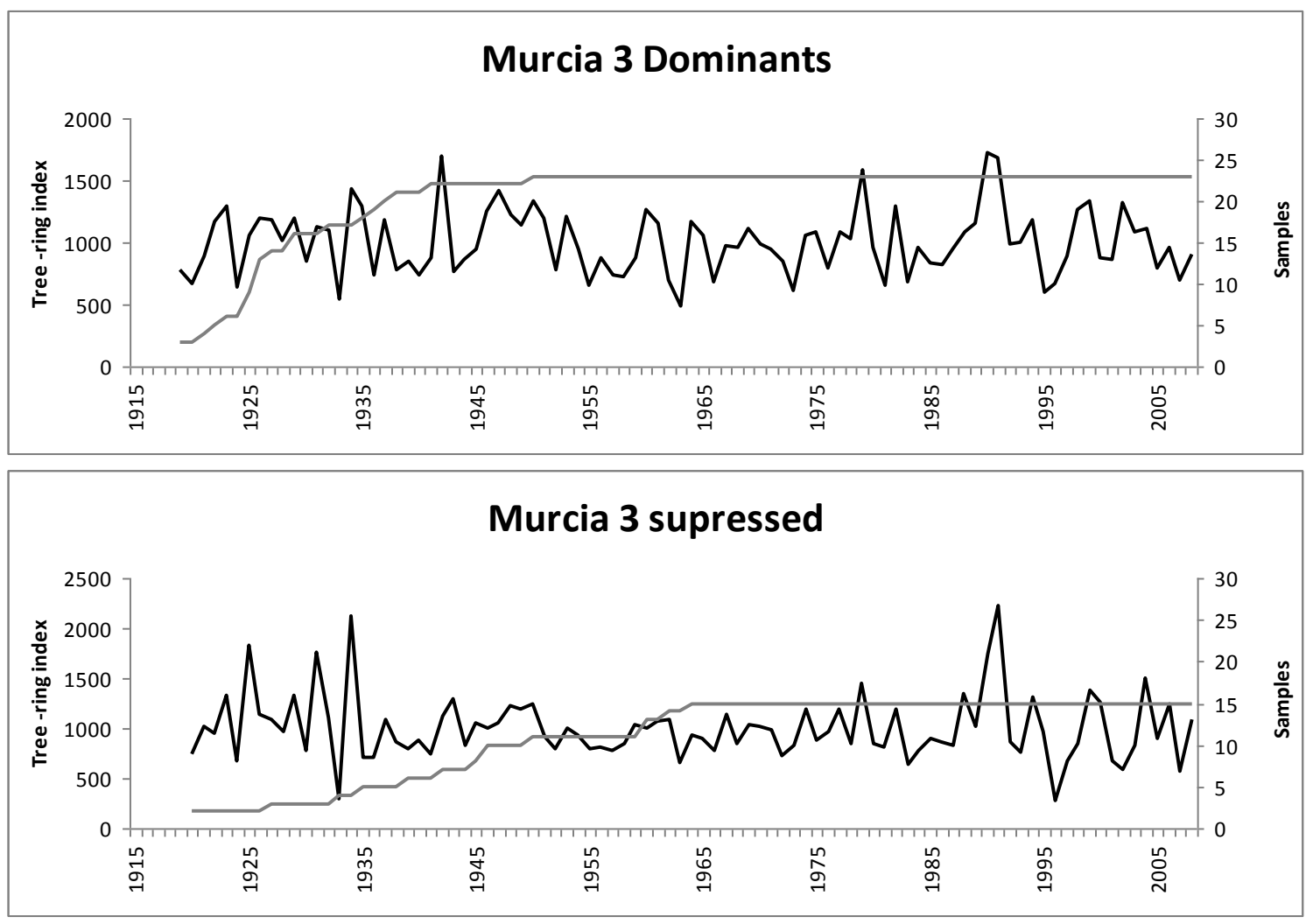

Fig. 2: Standardized chronologies of Pinus halepensis along the natural distribution in Spain. The black line shows the tree-ring index through time and the grey line shows the number of samples used in each chronology.

The master chronologies from Ampudia showed higher mean sensitivity values $(0.40$ for dominants and 0.37 for suppressed) than the other locations. The master chronology of the dominant trees in Ampudia also showed higher SNR and EPS (66.08 and 0.98 respectively) than the rest of the locations (Table 2). 
Table 2: Descriptive statistics of the master chronologies of Pinus halepensis. SD: standard deviation; MS: mean sensitivity; SNR: signal to noise ratio; EPS: expressed population signal; Var: variance in first eigenvector; and Mean corr.: mean correlation among trees.

\begin{tabular}{ccccccccccc}
\hline Code & $\begin{array}{c}\text { Crown } \\
\text { class }\end{array}$ & Location & Time span & $\begin{array}{c}\text { Core } \\
\text { num. }\end{array}$ & SD & MS & SNR & EPS & Var. & $\begin{array}{c}\text { Mean } \\
\text { corr. }\end{array}$ \\
\hline AmD & Dom. & Palencia & $1974-2008$ & 27 & 0.32 & 0.40 & 66.08 & 0.98 & $74.82 \%$ & 0.861 \\
Ams & Suppr. & Palencia & $1976-2008$ & 19 & 0.32 & 0.37 & 14.30 & 0.93 & $57.34 \%$ & 0.722 \\
CaD & Dom. & Aragón & $1977-2008$ & 30 & 0.25 & 0.33 & 28.70 & 0.96 & $70.28 \%$ & 0.819 \\
Cas & Suppr. & Aragón & $1981-2008$ & 29 & 0.31 & 0.36 & 15.57 & 0.94 & $63.16 \%$ & 0.755 \\
TaD & Dom. & Aragón & $1976-2008$ & 28 & 0.29 & 0.33 & 39.87 & 0.97 & $71.00 \%$ & 0.831 \\
Tas & Suppr. & Aragón & $1979-2008$ & 25 & 0.34 & 0.35 & 20.33 & 0.95 & $64.38 \%$ & 0.784 \\
Z1 & Dom. & Aragón & $1919-2007$ & 15 & 0.24 & 0.25 & 8.94 & 0.90 & $48.40 \%$ & 0.679 \\
Z2 & Dom. & Aragón & $1926-2007$ & 11 & 0.28 & 0.30 & 8.31 & 0.89 & $55.18 \%$ & 0.724 \\
MD1 & Dom. & Murcia & $1932-2008$ & 19 & 0.20 & 0.21 & 12.86 & 0.93 & $44.45 \%$ & 0.656 \\
Ms1 & Suppr. & Murcia & $1939-2008$ & 10 & 0.25 & 0.28 & 3.94 & 0.98 & $39.90 \%$ & 0.596 \\
MD2 & Dom. & Murcia & $1915-2008$ & 21 & 0.24 & 0.25 & 18.20 & 0.95 & $51.00 \%$ & 0.707 \\
Ms2 & Suppr. & Murcia & $1921-2008$ & 18 & 0.33 & 0.31 & 8.10 & 0.96 & $57.25 \%$ & 0.751 \\
MD3 & Dom. & Murcia & $1915-2008$ & 23 & 0.30 & 0.32 & 30.20 & 0.97 & $62.68 \%$ & 0.778 \\
Ms3 & Suppr. & Murcia & $1917-2008$ & 15 & 0.34 & 0.32 & 14.35 & 0.94 & $55.35 \%$ & 0.731 \\
\hline
\end{tabular}

The mean chronology of the suppressed trees showed slightly higher mean sensitivity values (0.30 for dominants and 0.33 for suppressed) and higher SNR values (26.64 for dominants and 12.77 for suppressed) than the mean chronology of the dominant trees. The mean chronology of the dominant trees also showed higher variance and mean correlation values than the mean chronology of the suppressed trees (Table 3).

Table 3: Descriptive statistics of the mean dominant and suppressed chronologies. SD: standard deviation; MS: mean sensitivity; SNR: signal to noise ratio; EPS: expressed population signal; Var: variance in first eigenvector; and Mean corr.: mean correlation among trees.

\begin{tabular}{ccccccccccc}
\hline $\begin{array}{l}\text { Social } \\
\text { class }\end{array}$ & Time span & $\begin{array}{c}\text { Av.core } \\
\text { num. }\end{array}$ & $\begin{array}{c}\text { Av.ring } \\
\text { num. }\end{array}$ & $\begin{array}{c}\text { Age } \\
\text { range }\end{array}$ & SD & MS & SNR & EPS & Var. $\begin{array}{c}\text { Mean } \\
\text { corr. }\end{array}$ \\
\hline Dom. & $1915-2008$ & 22 & 1139 & $95-27$ & 0.27 & 0.30 & 26.64 & 0.94 & 0.60 & 0.70 \\
Suppr. & $1917-2008$ & 19 & 732 & $92-20$ & 0.32 & 0.33 & 12.77 & 0.95 & 0.56 & 0.63 \\
\hline
\end{tabular}


Looking at the normalized curves (Fig. 3) it can be observed that dominant trees react stronger than suppressed trees in favourable years in Ampudia while in Tarazona suppressed trees react stronger than dominant trees in favourable years, the other sites show no patterns.
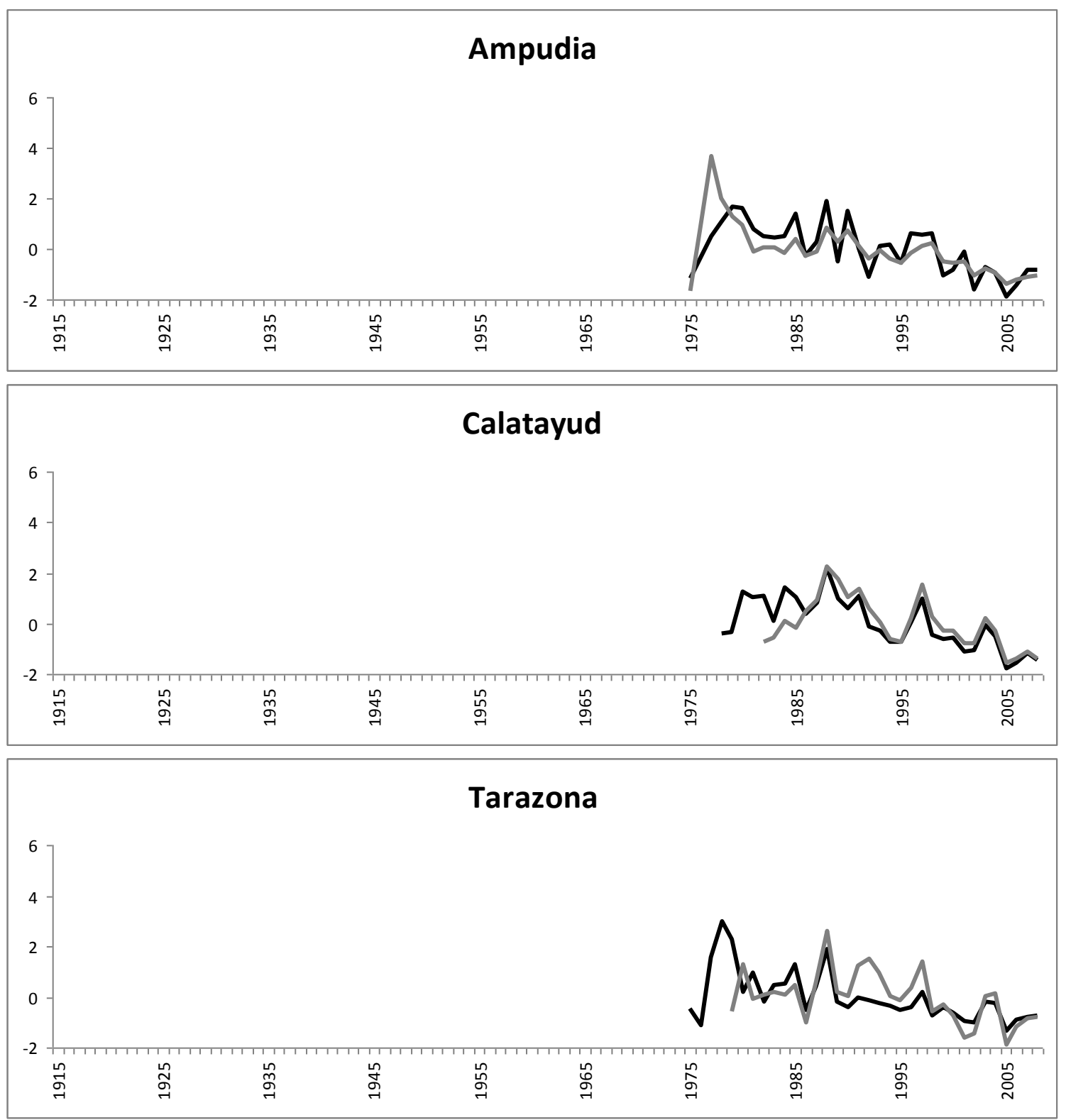

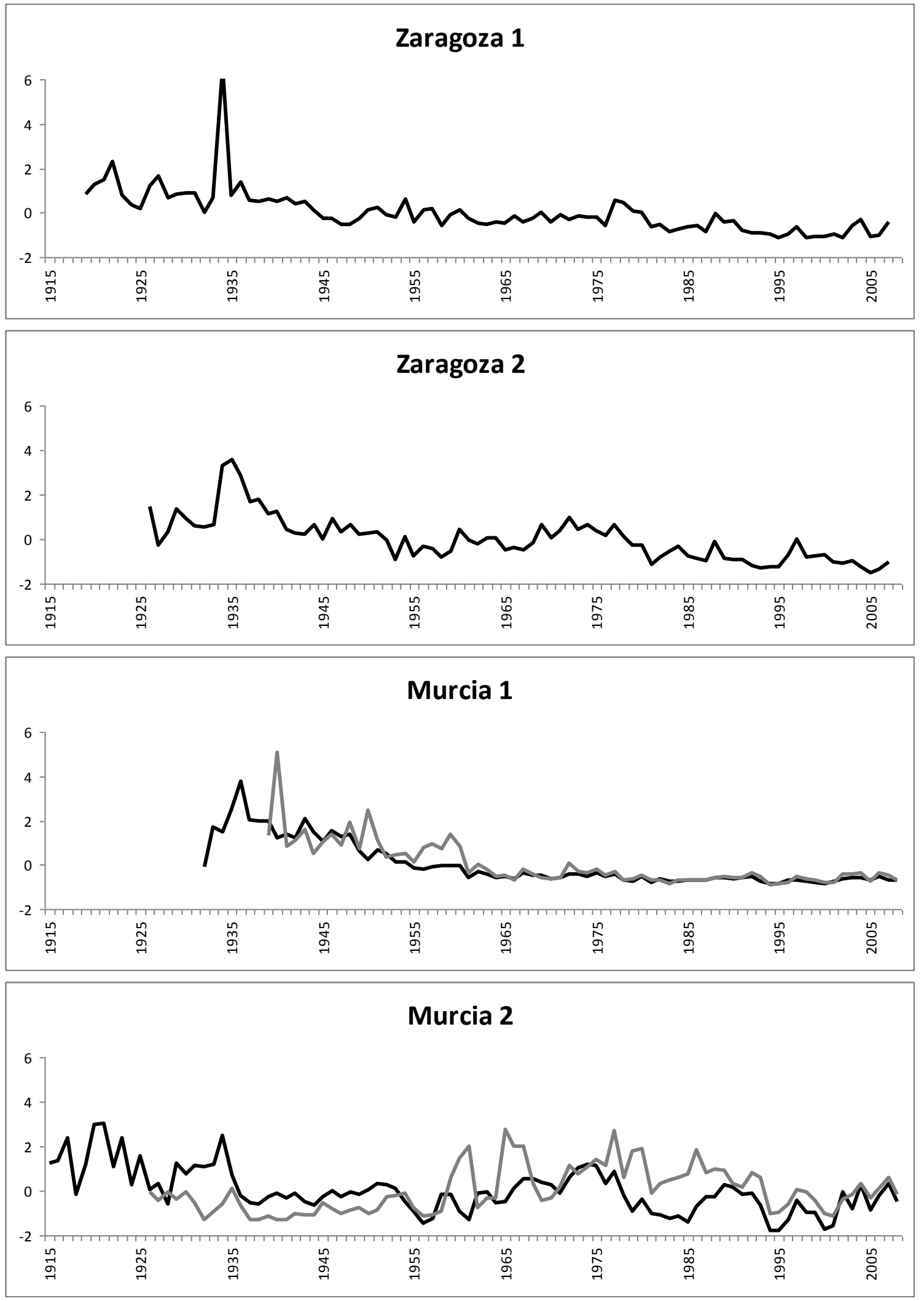


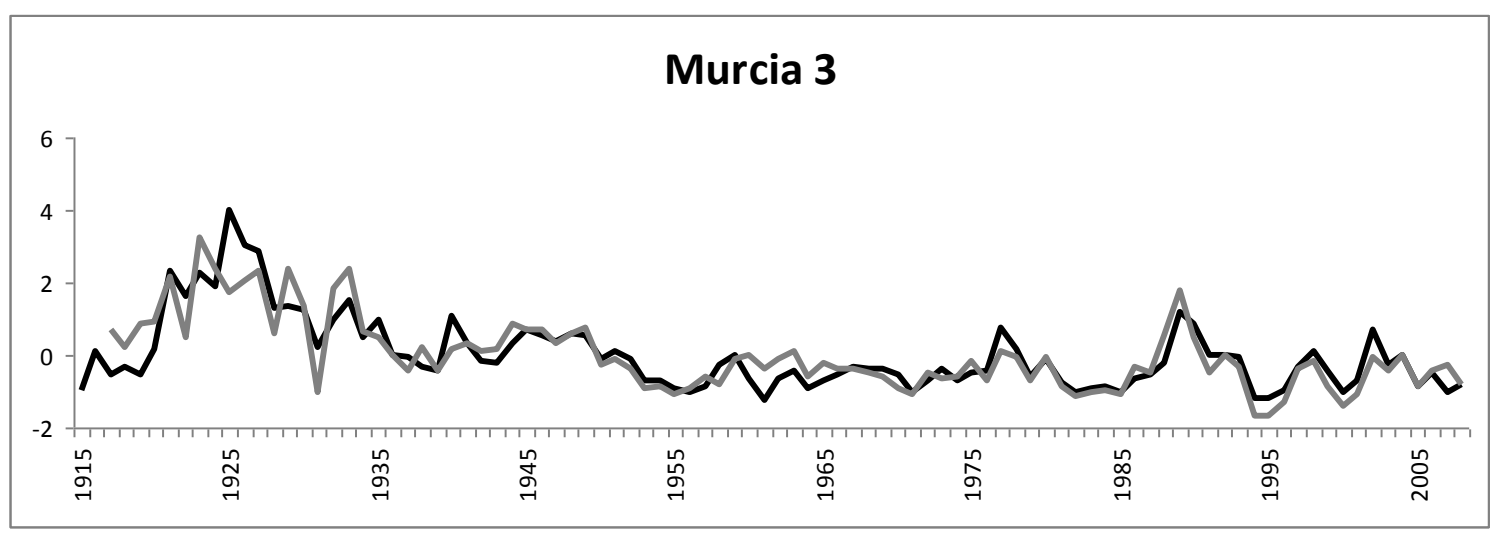

Fig. 3: Normalized chronologies of Pinus halepensis. The black line shows the mean dominant series and the grey line shows the mean suppressed series.

The Normalized Difference Index (Fig. 4) showed that, from 1980 to 2000 suppressed trees reacted stronger in Murcia and Aragón, while since 2000 no clear tendency was found.

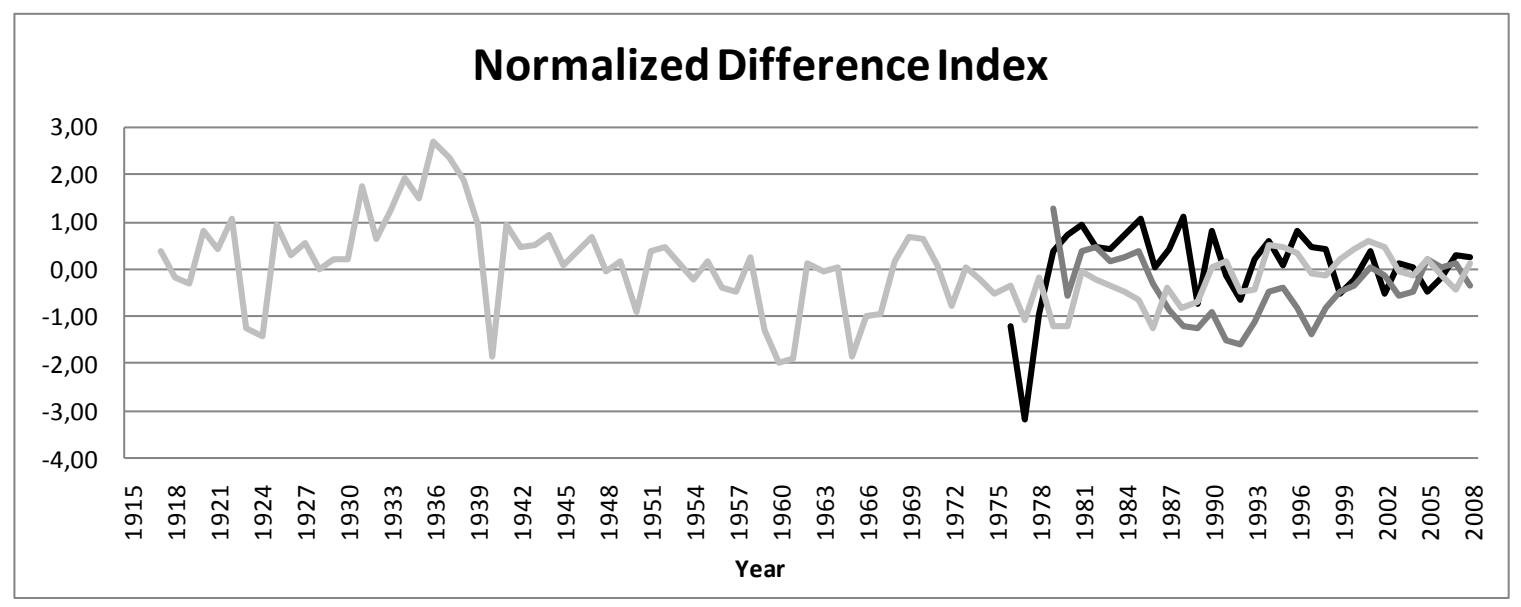

Fig. 4: Normalized Difference Index of Palencia (black line), Aragón (dark grey line) and Murcia (light grey line).

Relationships between climatic data and tree-ring widths

Relationships between mean seasonal temperatures mean seasonal precipitation and radial growth of the different crown classes in the eight sampling sites are presented in Figs. 5 and 6. 


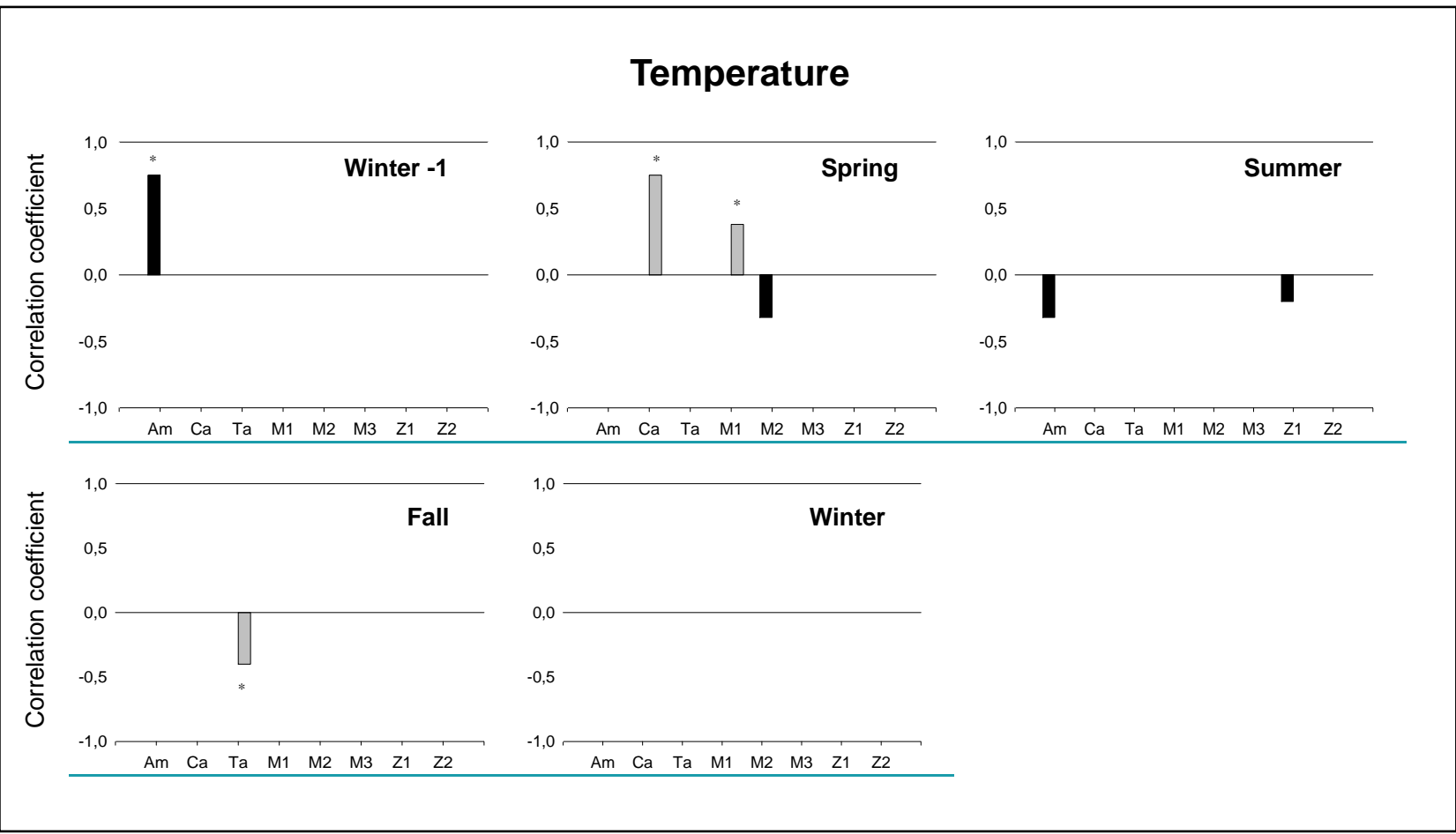

Fig. 5: Correlation coefficients between tree-ring width and temperature. Black bars represent dominant trees and grey bars represent suppressed trees $(* p<0.05)$.

Precipitation appeared to be the main factor influencing tree growth with significant values in all seasons, while temperature showed weak correlation values showing significant values in only two of the five seasons. Spring precipitation showed the most significant positive correlations followed by summer and winter previous to the growing season. 


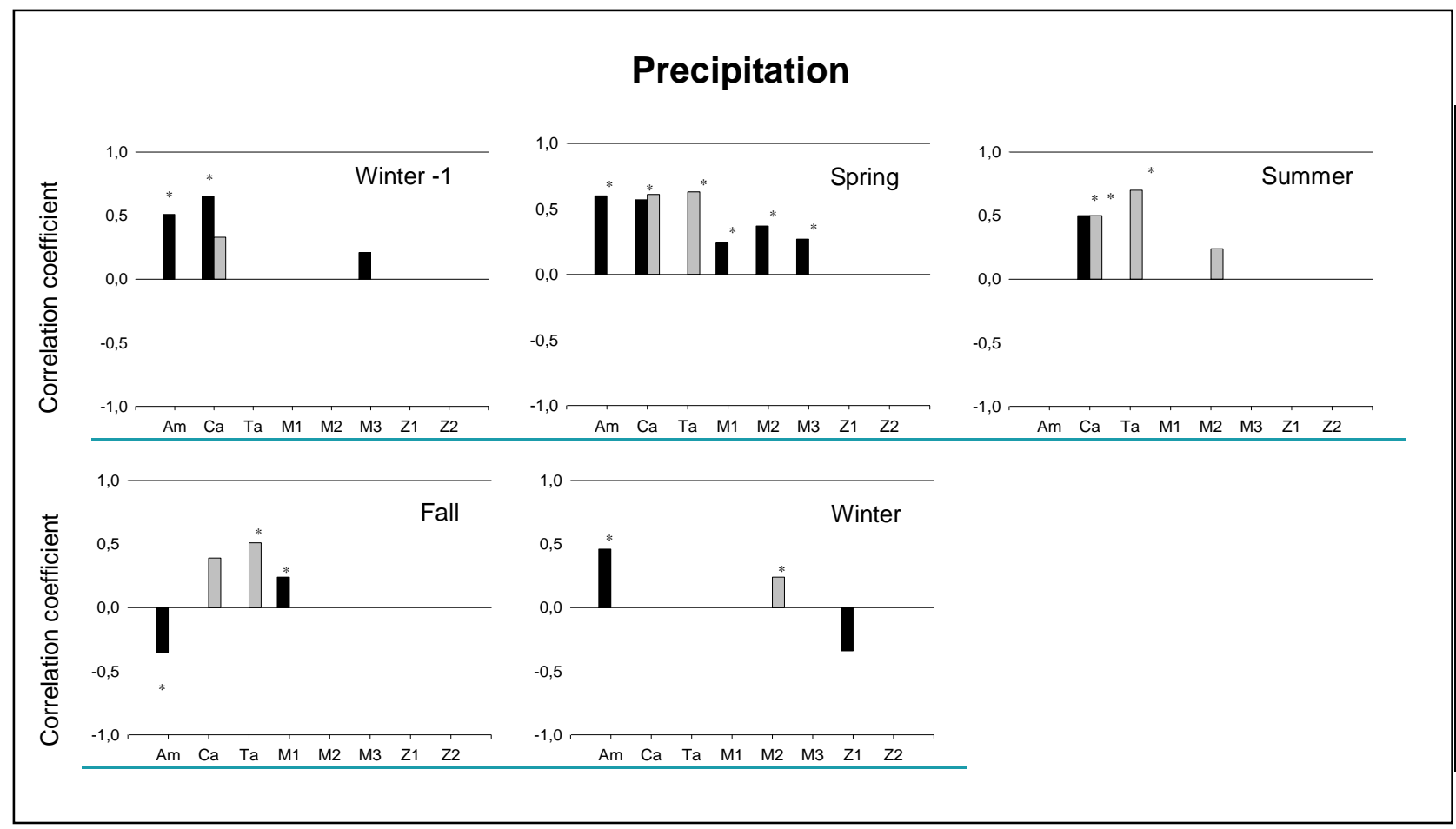

Fig. 6: Correlation coefficients between tree-ring width and precipitation. Black bars represent dominant trees and grey bars represent suppressed trees $(* p<0.05)$.

A total of 13502 tree rings were analysed from trees from the eight sampling sites and a total of 107 IADFs were found. Samples were grouped according to age and crown class (Table 4). 
Table 4: Descriptive statistics of the IADFs in Pinus halepensis according to age (younger than 80 years and older than 80 years) and crown class (dominant and suppressed).

\begin{tabular}{lcccc}
\hline & \multicolumn{2}{c}{ Age } & \multicolumn{2}{c}{ Crown class } \\
\cline { 2 - 5 } & $<\mathbf{8 0}$ & $>\mathbf{8 0}$ & Dom & Suppr \\
\hline Number of trees & 79 & 66 & 87 & 58 \\
Period & $1974-2008$ & $1915-2008$ & $1915-2008$ & $1917-2008$ \\
Trees with IADF & 28 & 33 & 32 & 30 \\
Trees with IADF (\%) & 41,77 & 43,94 & 36,78 & 51,72 \\
Tree rings in total & 4183 & 9319 & 9112 & 4390 \\
Tree rings with IADFs & 67 & 40 & 64 & 43 \\
Proportion of IADF & 0.016 & 0.004 & 0.007 & 0.010 \\
Mean stabilized IADF & 0.65 & 0.55 & 0.61 & 0.61 \\
\hline
\end{tabular}

The percentage of trees with IADFs was rather similar for young and old stands. However, the percentage of IADFs and the mean stabilized IADF was higher for young stands than for old stands. The percentage of trees with IADFs and the percentage of IADFs were both higher for suppressed than dominant trees. Mean stabilized IADF was the same for both crown classes.

Intra-annual density fluctuations

The nonlinear logistic equation form was chosen to model the probability of occurrence of IADFs with monthly precipitation and mean monthly temperature as variables (Table 5). 
Table 5: Stepwise selection (pp: monthly precipitation; tt: mean monthly temperature; AIC: Akaike's Information Criterion; L: likelihood).

Variables included in the model

AIC $\quad-2 * \log \mathrm{L}$

pp-October

$519.728 \quad 515.728$

pp-July, pp-October

$505.353 \quad 499.353$

pp-June, pp-July, pp-October

491.281

483.281

tt-May, pp-June, pp-July, pp-October

478.292

468.292

tt-September, tt-May, pp-June, pp-July, pp-October

460.197

448.197

pp-May, tt-September, tt-May, pp-June, pp-July, pp-October

453.722

439.722

pp-August, pp-May, tt-September, tt-May, pp-June, pp-July, pp-October

450.977

434.977

pp-October, pp-August, pp-May, tt-September, tt-May, pp-June, pp-July, pp-October

445.196

427.196

pp-October, pp-August, tt-September, tt-May, pp-June, pp-July, pp-

October

445.241

429.241

pp-November, pp-October, pp-August, tt-September, tt-May, pp-June, ppJuly, pp-October

$440.880 \quad 422.880$

tt-July, pp-November, tt-October, tt-July, pp-October t, pp-August, tt-

September, tt-May, pp-June, pp-July, pp-October

$433.910 \quad 413.910$

pp-March, tt-July, pp-November, tt-October, tt-July, pp-October, pp-

August, tt-September, tt-May, pp-June, pp-July, pp-October

$426.127 \quad 404.127$

The logistic function estimated that 10 monthly climatic variables out of 24 had a significant effect on predicting future IADFs (Tables 6 and 7). 
Table 6: Climatic variables with a significant effect on the probability of IADFs in Pinus halepensis (pp:monthly precipitation; tt:mean monthly temperature).

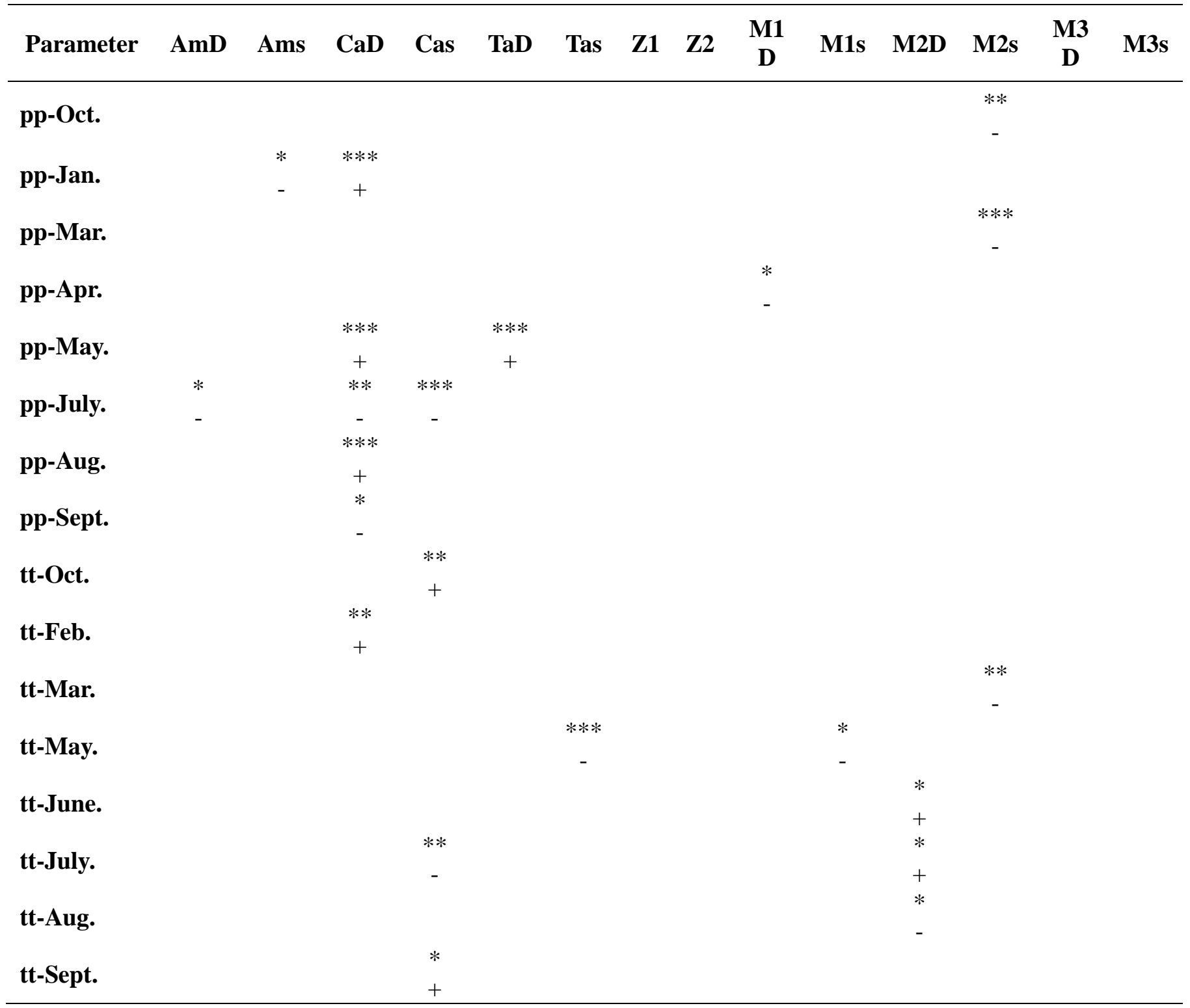

$*_{p}<0.05, * * p<0.01, * * * p<0.001$, the absence of an asterisk shows that there was no significant association.

The model showed that, without considering crown classes, precipitations in October, December, March, April, June and mean monthly temperatures in June and September had a positive impact on the formation of IADFs, while precipitations in November and July and mean monthly temperatures in May had a negative impact on the formation of IADFs. Precipitations in December and April had a positive impact on the formation of IADFs in 
both dominant and suppressed trees, while precipitations in July had a negative impact.

Table 7: Climatic variables with a significant effect on the probability of IADFs in Pinus halepensis (pp:monthly precipitation; tt:mean monthly temperature).

\begin{tabular}{|c|c|c|c|c|c|c|c|c|c|c|c|c|}
\hline \multirow{2}{*}{ Parameter } & \multicolumn{4}{|c|}{ All } & \multicolumn{4}{|c|}{ Dominant } & \multicolumn{4}{|c|}{ Suppressed } \\
\hline & Estim. & $\begin{array}{c}\text { St. } \\
\text { Error }\end{array}$ & $\begin{array}{l}\text { Wald } \\
\text { Chi }^{2}\end{array}$ & $\operatorname{Pr}>\mathrm{Chi}^{2}$ & Estim. & $\begin{array}{c}\text { St. } \\
\text { Error }\end{array}$ & $\begin{array}{l}\text { Wald } \\
\text { Chi }^{2}\end{array}$ & $\operatorname{Pr}>\mathrm{Chi}^{2}$ & Estim. & $\begin{array}{c}\text { St. } \\
\text { Error }\end{array}$ & $\begin{array}{l}\text { Wald } \\
\text { Chi }^{2}\end{array}$ & $\operatorname{Pr}>\mathrm{Chi}^{2}$ \\
\hline Intercept & 8.05 & 3.22 & 6.25 & 0.01 & 8.98 & 3.55 & 6.41 & 0.01 & 5.98 & 3.82 & 2.45 & 0.12 \\
\hline pp-Oct. & -0.03 & 0.01 & 17.26 & $<.0001$ & & & & & & & & \\
\hline pp-Nov. & 0.04 & 0.01 & 14.67 & 0.00 & & & & & & & & \\
\hline pp-Dec. & -0.07 & 0.01 & 38.20 & $<.0001$ & -0.08 & 0.01 & 29.14 & $<.0001$ & -0.09 & 0.02 & 21.90 & $<.0001$ \\
\hline pp-Jan. & & & & & & & & & 0.12 & 0.04 & 9.53 & 0.00 \\
\hline pp-Mar. & -0.02 & 0.01 & 9.01 & 0.00 & & & & & & & & \\
\hline pp-Apr. & -0.02 & 0.01 & 8.64 & 0.00 & -0.02 & 0.01 & 8.08 & 0.00 & -0.07 & 0.03 & 6.08 & 0.01 \\
\hline pp-May. & & & & & -0.03 & 0.01 & 7.11 & 0.01 & & & & \\
\hline pp-June. & -0.06 & 0.01 & 22.72 & $<.0001$ & -0.06 & 0.02 & 17.27 & $<.0001$ & & & & \\
\hline pp-July. & 0.03 & 0.01 & 23.08 & $<.001$ & 0.02 & 0.01 & 4.69 & 0.03 & 0.07 & 0.02 & 14.13 & 0.00 \\
\hline tt-Nov. & & & & & & & & & 1.75 & 0.53 & 10.88 & 0.00 \\
\hline tt-Dec. & & & & & & & & & -1.40 & 0.45 & 9.48 & 0.00 \\
\hline tt-May. & 0.72 & 0.15 & 23.20 & $<.0001$ & & & & & 0.67 & 0.29 & 5.35 & 0.02 \\
\hline tt-June. & -0.50 & 0.15 & 10.66 & 0.00 & -0.40 & 0.16 & 6.50 & 0.01 & & & & \\
\hline tt-Sept. & -0.51 & 0.14 & 12.94 & 0.00 & & & & & -1.69 & 0.52 & 10.39 & 0.00 \\
\hline
\end{tabular}

The area underneath ROC curve was 0.918 for all trees, 0.917 for dominant trees and 0.943 for suppressed trees. The accuracy of the model is also sufficient to use it to predict occurrence of IADFs. IADF frequency in relation to calendar year (Fig. 7) showed an increase in IADFs from the 1980s to the present. 1983, 1989, 1995 and 1999 were the years with more IADFs, with a stabilized frequency higher than 0.2. 


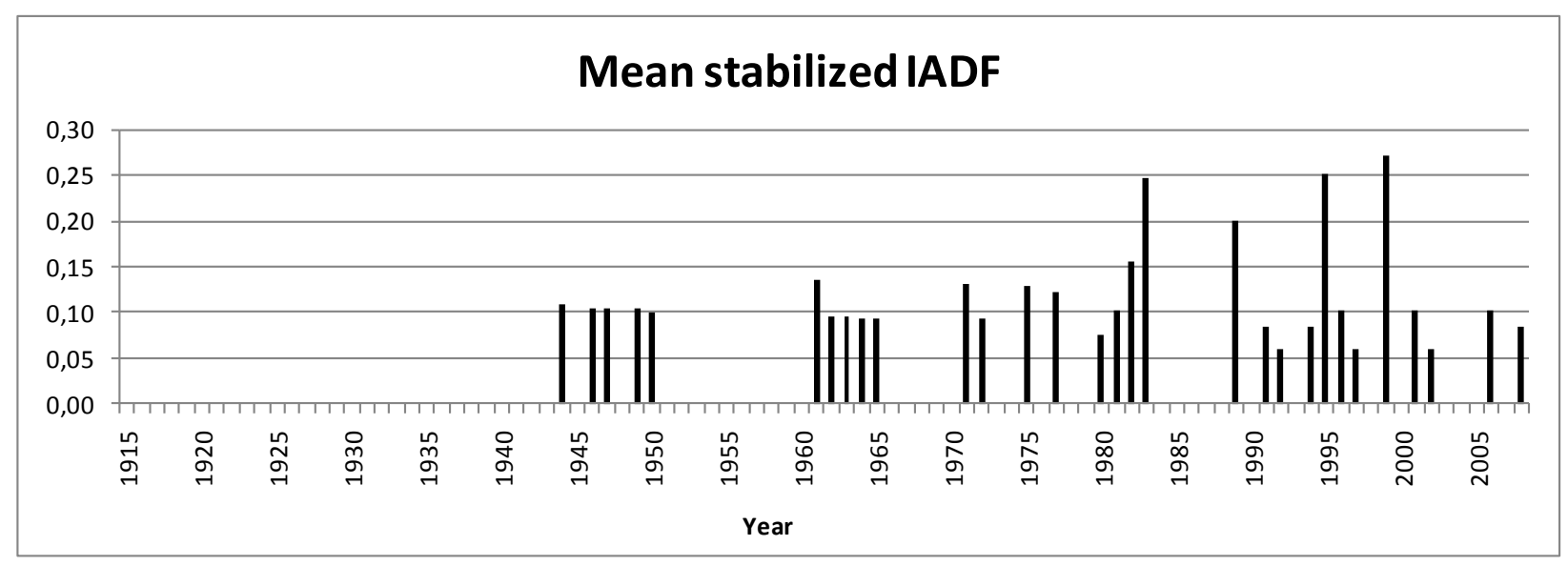

Fig. 7: Mean stabilized IADF in relation to calendar year.

\section{Discussion}

Pinus halepensis appears as a reliable species for dendrochronological studies, showing good correlations between trees growing at the same site, high expressed population signals and accurate statistical values which suggest a clear response to environmental factors. In addition, it confirms the tendency of Mediterranean species to develop special anatomical structures (Schweingruber, 1993). We found common radial growth patterns among dominant and suppressed series in the same site. These results agree with previous studies in Spain suggesting that pine species growing in the southern dendroecological section could have a common growth response to environmental factors (Richter et al., 1991; Bogino and Bravo, 2008).

The descriptive statistics of the chronologies suggest that the tree-ring series reflects one or more associated factors (including climate), and a strong response of radial growth dynamics to changes in climatic conditions shown by the mean sensitivity values (MS) from 0.21 to 0.40 that are higher than the 0.16 to 0.34 values found in previous studies on pine species (Pinus sylvestris L., Pinus nigra Arnold, Pinus pinaster Ait. and Pinus mugo ssp. uncinata Turra.) in the Iberian Peninsula (Richter et al., 1991; Bogino and Bravo, 2008; Martin-Benito et al., 2008; Bogino and Bravo, 2009; Bogino et al., 2009; Vieira et al., 2009).

The expressed population signal (EPS) ranging from 0.89 to 0.98 is in all cases higher than the critical level of 0.85 suggested by Wigley et al. (1984), which implies that the 108 
chronologies are representative of tree growth in the stands. First eigenvector variance ranges from 39.90 to $74.82 \%$, indicating good homogeneity within the same site. It can be concluded that the fourteen mean chronologies have high MS, SNR, EPS and percentage of the variance accounted for by the first eigenvector, suggesting a strong common signal to related-climatic environmental factors. Ampudia showed higher values of MS, SNR and EPS than the other two locations, especially the dominant trees. However, in the regions of Aragón and Murcia the mean suppressed series showed a higher sensitivity than the mean dominant series. There is evidence that suppressed trees suffer greater drought stress because of greater root competition for soil. However, understory trees receive lower solar radiation and higher wind protection by the influence of neighbouring crowns reducing transpiration rates. Therefore, climate sensitivity may be reduced (Bréda et al., 2006; Martin-Benito et al., 2008). In Mediterranean forests stand density is low and the protection effect from the dominant to the suppressed trees gets reduced.

The results show that $P$. halepensis growth is mainly controlled by precipitation. Previous studies reported that growth of Aleppo pine is controlled by soil water availability (Rathgeber et al., 2005) and precipitation is the main factor influencing tree growth of pine species in semiarid Mediterranean conditions (Raventós et al., 2001). Winter previous to the growing season and spring precipitation are related positively with tree-ring growth. The same results were found in the Attica basin (Greece) (Papadopoulos et al., 2008). Other Mediterranean pine species showed similar results: growth of Pinus pinea in a dry Mediterranean area in Portugal, Pinus pinaster in central Spain and Pinus sylvestris at its southern distribution limits were positively correlated with rainfall (Campelo et al., 2007; Bogino and Bravo, 2008; Bogino et al., 2009). Growth of Pinus nigra in central Spain and Pinus pinaster in Portugal were mainly influenced by May precipitation (Martin-Benito et al., 2008; Vieira et al., 2009).

We found a higher tendency in young stands for developing IADFs. These results corroborate previous dendroecological studies which suggested that IADFs were more frequent in younger tree rings (Rigling et al., 2001; Villalba and Veblen, 1994; Vieira et al., 2009; Bogino and Bravo, 2009). This could be due to a faster response of young trees to changing factors (Villalba and Veblen, 1994) and/or to a longer growing season of young 
trees (Rossi et al., 2008). Since young trees have a different response to environmental factors than old trees, the incorporation of age-dependent differences on the appearance of special ring features such as IADFs and its association to climatic variables in any dendrochronological study provides a useful proxy for complementing and enhancing the dendroclimatological data. In addition, it can give important clues to predict differences on how young and old trees react to climate change.

The occurrence of IADFs in Pinus halepensis was positively correlated with precipitation in December and April and negatively correlated with precipitation in July. These results are consistent with those of previous studies in Pinus pinaster in central Spain, where IADFs were mainly correlated with rainfall pulses in late winter and spring (Bogino and Bravo, 2009). IADFs correlated positively with precipitation events early in summer following a water deficit early in the growing season in Pinus pinea in southern Portugal (Campelo et al., 2007), which is consistent with the present results that showed precipitation in July to have a negative effect on IADFs. Favourable climatic conditions in winter and spring as well as water deficits early in the growing season followed by rainfall indicate an increase in the probability of the occurrence of IADFs. This corroborates that growth may temporarily stop, but is always ready to resume activity as soon as climatic conditions become favourable.

Winter precipitation that precedes the formation phase of the tree-rings as well as the spring rainfall at the beginning of the tree-growth play a prevailing role to the development of wider tree rings in P. halepensis (Papadopoulos et al., 2008). These climatic conditions coincide with the favourable conditions for the formation of IADFs in our study. Therefore we can agree with previous studies that have shown that IADFs are more frequent in wider tree rings (Vieira et al., 2009; Rigling et al., 2001; Villalba and Velben, 1994). As it was previously reported (Bogino and Bravo, 2009) a higher frequency in IADFs occurred in the last fifty years. The increase in drought events in Spain (IPCC 2007) may explain the higher IADF frequency during this period. 


\section{Conclusions}

Pinus halepensis is an accurate species for tree-ring analysis with good correlations between trees growing at the same site and a clear response to environmental factors. Suppressed trees showed higher sensitivity than dominant trees, with greater growth rates during favourable years except for Ampudia, where dominant trees showed higher sensitivity than suppressed trees. Precipitation was the main factor influencing tree-ring growth. IADFs were more frequent in young than in old stands with no clear differences according to crown classes. The probability model used, showed that high precipitation in spring and winter indicates an increase in the probability of the occurrence of IADFs, while high precipitation in July indicates a decrease in the probability of the occurrence of IADFs. A higher frequency in IADFs occurred in the last fifty years, which coincides with the increase in drought events in Spain.

\section{Acknowledgements}

The authors wish to thank the COST-Action FP0703 "Expected Climate Change and Options for European Silviculture" (ECHOES), the Spanish National Project AGL-200765795-C02-01, the Spanish Meteorological Agency for providing the meteorological data and Antonio Urchaga, Cristóbal Ordoñez, Encarna García, Irene Ruano, Javier Castaño, Luis Fernando Osorio, María Menéndez and Wilson Lara for assisting in field data collection.

\section{References}

Attolini, M. R., Calvani, F., Galli, M., Nanni, T., Ruggiero, L., Schaer, E., Zuanni, F., 1990. The relationship between climatic variables and wood structure in Pinus halepensis Mill. Theoretical and Applied Climatology 41: 121-127.

Bogino, S., Bravo, F., 2008. Growth response of Pinus pinaster Ait. to climatic variables in central Spanish forests. Annals of Forest Science 68: 506-518.

Bogino, S., Bravo, F., 2009. Climate and intra-annual density fluctuations in Pinus pinaster 
subsp. Mesogeensis in Spanish woodlands. Canadian Journal of Forest Research 39 (8): 1557-1565.

Bogino, S., Fernández Nieto, M. J., Bravo F., 2009. Climate effect on radial growth of Pinus sylvestris at its southern and western distribution limits. Silva Fennica 43 (4): 609623.

Bréda, N., Huc, R., Granier, A., Dreyer, E., 2006. Temperate forest trees and stands under severe drought: a review of ecophysiological response, adaptation processes and long-term consequences. Annals of Forest Science 42: 206-219.

Briffa, K. R., Osborn, T. J., Schweingruber, F. H., 2003. Large-scale temperature inferences from tree rings: a review. Global and Planetary Change 40: 11-26.

Campelo, F., Nabais, C., Freitas, H., Gutiérrez, E., 2007. Climatic significance of tree-ring width and intra-annual density fluctuations in Pinus pinea from a dry Mediterranean area in Portugal. Annals of Forest Science 64: 229-238.

Cook, E. R., Holmes, R. L., 1984. Program Arstan users manual. Laboratory of tree ring research, University of Arizona, Tucson, USA.

Fritts, H. C., Swetnam, T. W., 1989. Dendroecology: a tool for evaluating variations in past and present environments. Advances in Ecological Research 19: 111-188.

Fritts, H. C., 2001. Tree rings and climate. The Blackburn press, London.

Grissino-Mayer, H. D., 2001. Evaluating crossdating accuracy: a manual and tutorial for the computer program Cofecha. Tree-ring Research 57: 205-221.

Hair, J. E., Anderson, R.E., Tatham, R. L., Black, W.C., 1998. Multivariate data analysis. 5th ed. Prentice Hall, Upper Saddle River, New Jork, Usa.

Hosmer, D. W., Lemeshow, S., 2000. Applied logistic regression. John Wiley \& sons inc., $375 \mathrm{pp}$.

Holmes, R. L., 2001. Dendrochronology program library. Laboratory of tree ring research, 
University of Arizona, Tucson, USA.

IPCC 2007. Fourth assessment report of the intergovernmental panel on climate change. Cambridge University Press, Cambridge, United Kingdom and New York, NY, USA.

Kaennel, M., Schweingruber, F.H. 1995. Multilingual Glossary of Dendrochronology. Paul Haupt publishers Berne, Stuttgart, Vienna.

Lavorel, S., Canadell, J., Rambla, S., Terradas, J., 1998. Mediterranean terrestrial ecosystems: research priorities on global change effect. Global Ecology and Biogeography Letters 7: 157-166.

Martin-Benito, D., Cherubini, P., del Rio, M., Cañellas, I., 2008. Growth response to climate and drought in Pinus nigra Arn. trees of different crown classes. Trees 22: 363-373.

Montero, G., Cañellas, I., Ruíz-Peinado, R., 2001. Growth and yield models for Pinus halepensis Mill. Investigaciones Agrarias: Sistemas y Recursos Forestales 10 (1): 179-201.

Osborn, T.J., Briffa, K.R., Jones, P.D., 1997. Adjusting variance for sample-size in tree-ring chronologies and other regional mean time series. Dendrochronologia 15: 1-10.

Papadopoulos, A., Tolica, K., Pantera, A., Maheras, P., 2008. Investigation of the annual variability of the Aleppo pine tree-ring width: the relationship with the climatic conditions in the Attica basin. Global Nest Journal.

Raventós, J., de Luís, M., Gras, M., Cufar, K., González-Hidalgo, J., Bonet, A., Sánchez, J., 2001. Growth of Pinus pinea and Pinus halepensis as affected by dryness, marine spray and land use changes in a Mediterranean semiarid ecosystem. Dendrochronologia 19: 211-220.

Rathgeber, C., Misson, L., Nicault, A., Guiot, J., 2005. Bioclimatic model of tree radial growth: application to French Mediterranean Aleppo pine forests. Trees 19: 162-176.

Richter, K., Eckstein, D. Holmes, R. L., 1991. The dendrochronological signal of pine trees (Pinus spp.) in Spain. Tree-ring Bulletin 51: 1-13.

Rigling, A., Waldner, P. O., Forster, T., Bräker O. U., Pouttu, A., 2001. Ecological 
interpretation of tree-ring width and intra-annual density fluctuations in Pinus sylvestris on dry sites in the central Alps and Siberia. Canadian Journal of Forest Research 31: 18-31.

Rigling, A., Braker, O., Schneiter, G., Schweingruber, F., 2002. Intra-annual tree-ring parameters indicating differences in drought stress of Pinus sylvestris forests within the Erico-Pinion in the Valais (Switzerland). Plant Ecology 163: 105-121.

Rossi, S., Deslauriers, A., Anfodillo, T., Carrer, M., 2008. Age-dependent xylogenesis in timberline conifers. New Phytologist 177,199-208.

Sas Institute inc., 2004. Sas/stat versión 9.1, user's guide. Cary, NC, USA.

Schweingruber, F. H., 1993. Trees and wood in dendrochronology. Springer series in 324 wood science, Springer-Verlag.

Stokes, M., Smiley, T., 1968. An introduction to tree-ring dating, University of Arizona press, Tucson, USA.

Vieira, J., Campelo, F., Nabais, C., 2009. Age-dependent responses of tree-ring growth and intra-annual density fluctuations of Pinus pinaster to Mediterranean climate. Trees 23: 257265

Villalba, R., Veblen, T. T., 1994. A tree-ring record of dry spring wet summer events in the forest-steppe ecotone northern Patagonia, Argentina. In: dean js, meko dm, swetnam tw (eds) tree rings environment and humanity. Radiocarbon, spec. Issue, pp 107-116.

Wigley, T. M. L., Briffa, K. R., Jones, P. D., 1984. On the average value of correlated time series, with applications in dendroclimatology and hydrometeorology. Journal of Applied Meteorology and Climatology 23: 201-213. 


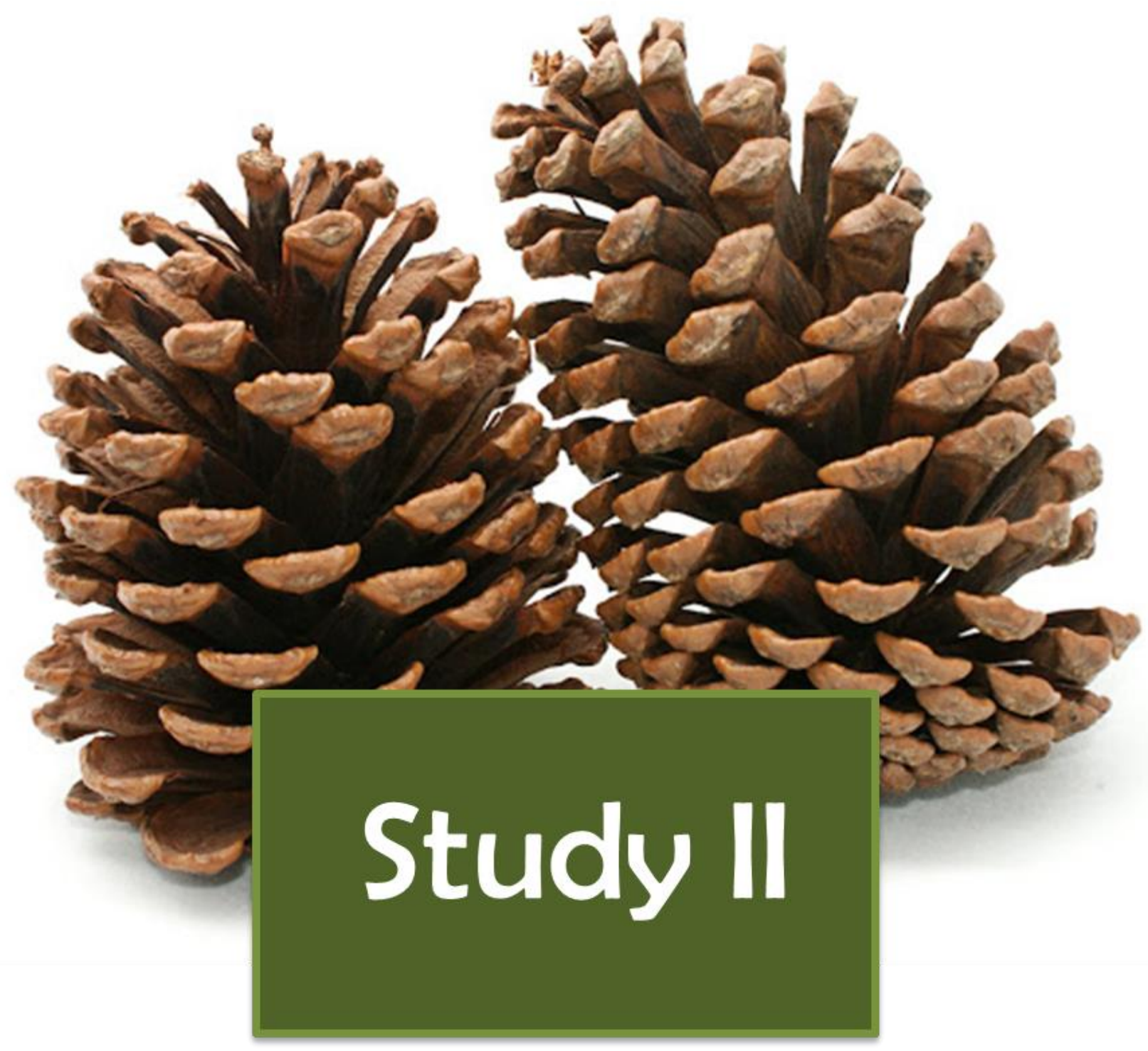

Changes in climate-growth relationships and IADF formation over time in Mediterranean pine species (Pinus halepensis, P. pinaster and P. sylvestris) in Spain

* Olivar, J., Bogino, S., Spiecker, H., Bravo, F., 2013. Changes in climate-growth relationships and IADF formation over time in Mediterranean pine species (Pinus halepensis, P. pinaster and P. sylvestris) in Spain. Submited to European Journal of Forest Research. 
Olivar (2013)

116 


\title{
Changes in climate-growth relationships and IADF formation over time in Mediterranean pine species (Pinus halepensis, $P$. pinaster and $P$. sylvestris) in Spain
}

Jorge Olivar ${ }^{1}$, Stella Bogino ${ }^{3}$, Heinrich Spiecker ${ }^{2}$, Felipe Bravo ${ }^{1}$

${ }^{1}$ Sustainable Forest Management Research Institute University of Valladolid-INIA. Avda. de Madrid 44, 34004, Palencia (Spain)

${ }^{2}$ Institute for Forest Growth, Albert-Ludwigs-Universität Freiburg. Tennenbacherstr. 4, D-79106 Freiburg (Germany)

${ }^{3}$ Departamento de Ciencias Agropecuarias. Facultad de Ingeniería y Ciencias Económico-Sociales. Universidad Nacional de San Luis. Avda. 25 de Mayo 384, 5730 Villa Mercedes, San Luis (Argentina)

\begin{abstract}
The Mediterranean area has experienced an increase in the mean annual temperature, a decrease in the mean annual precipitation, and an increase in the frequency of severe drought periods during the second half of the $20^{\text {th }}$ century. However, winter and spring precipitation has increased and summer precipitation has decreased in western Mediterranean region. The objectives of the present study were: i) to identify and compare changes in climate-growth relationships along time for Pinus halepensis, $P$. pinaster and $P$. sylvestris in Spain ii) to quantify and compare the presence of intra-annual density fluctuations (IADFs) on the three species and iii) to define the climatic variables that are associated with the occurrence of IADFs. Dendrochronological techniques were applied at 26 sampling sites (8 for $P$. halepensis, 8 for $P$. pinaster and 10 for $P$. sylvestris) in Spain. Results showed that precipitation is the main factor influencing tree growth and its fluctuation determines IADF occurrence in the three pine species, $P$. pinaster being the species that had the highest correlation values. Wet periods during winter previous to the growth season and spring induced higher growth rates on $P$. halepensis and $P$. pinaster, while the growth of $P$. sylvestris was mostly influenced by summer precipitation. However, the influence of these climatic variables on the growth of these species changed over the studied period. The increase of winter and spring precipitation combined with increasingly
\end{abstract}


harsh climatic conditions during summer in the second half of the $20^{\text {th }}$ century may have enhanced the importance of precipitation at the beginning of the growing season on the growth of species subject to higher drought stress conditions during summer, such as $P$. halepensis and $P$. pinaster and increased the IADF occurrence. Besides reflecting changes in the environmental conditions during the growing season, the inclusion of IADF detection in chronologies adds new information to ring-width chronologies, thereby improving its quality.

\section{Key words}

Aleppo pine, maritime pine, scots pine, dendroclimatology, IADFs.

\section{Introduction}

Mediterranean environments, as transitional climate zones between arid and humid regions of the world, are of special interest for the study of the relationships between climate, tree growth and wood anatomic features. In addition, the Mediterranean is one of the areas where climatic changes may have the greatest effects (Lavorel et al., 1998). Mediterranean forests are the most important ecological infrastructure of the region, providing goods and services and acting as a key for the resilience and adaptability. Pinus halepensis, P. pinaster and $P$. sylvestris are native pines in the Mediterranean region and dominate the current forested landscape. Previous studies on P. halepensis concluded that its growth rate is mainly controlled by soil water availability (Rathgeber et al., 2005). Pinus halepensis has been the subject of several dendroecological and dendroclimatological studies in some Mediterranean regions such as Spain (de Luis et al., 2007; de Luis et al., 2011; MorenoGutiérrez et al., 2012; Olivar et al., 2012; Novak et al., 2013), Greece (Papadopoulos et al., 2008), Israel (Lev-Yadun et al., 1981), Morocco (Chbouki et al., 1995) and Algeria (Safar, 1994). Radial growth of $P$. pinaster is positively correlated with precipitation in Portugal (Vieira et al., 2010; Campelo et al., 2013) and central Spain (Bogino and Bravo, 2008). This fact was also reported for $P$. sylvestris in its southern and western distribution threshold in Spain (Bogino et al., 2009). 
Climatic influences on tree growth are unstable, species specific and site dependent (Tardif et al., 2003). Climate change is resulting in both positive and negative trends in tree growth, the latter frequently observed in drought-stressed environments (Camarero et al., 2010). The influence of climatic variables on growth can be modified over time (Andreu et al., 2007) and previous studies showed a changing association between climatic variables and growth of Pinus species in the Mediterranean area (Bogino and Bravo, 2008, Vieira et al., 2010; Campelo et al., 2013). During the second half of the 20th century, an overall increase of the mean annual temperature, a decrease of the annual precipitation and a higher frequency of severe drought periods have been observed in the Mediterranean area (Martrat et al., 2004; Xoplaki et al., 2006). However, in the western Mediterranean regions, winter and spring precipitation increased and summer precipitation decreased during that period (Bradley et al., 1987; Maheras, 1988; Díaz et al., 1989).

The analysis of temporal and seasonal dynamics of intra-annual cell formation and wood density profiles is a relevant topic in the literature of the last years (Edmondson, 2010; Bender et al., 2012; Harley et al., 2012). Species growing under Mediterranean climate, with summer droughts and high inter-annual variability in precipitation and temperature, commonly show special anatomical characteristics in tree rings (Schweingruber, 1993). Intra-annual density fluctuations (IADFs) are defined as a layer of cells within a tree ring identified by different shape, size and wall thickness (Kaennel and Schweingruber, 1995). Different studies in conifer species: P. halepensis (de Luis et al., 2007; de Luis et al., 2011; Moreno-Gutiérrez et al., 2012; Olivar et al., 2012; Novak et al., 2013) P. pinaster (de Micco et al., 2007; Bogino and Bravo, 2009; Vieira et al., 2010; Rozas et al., 2011; Campelo et al., 2013) and P.sylvestris (Panayotov et al., 2013), and broadleaved species (Battipaglia et al., 2010; de Micco et al., 2012) have shown good correlations between IADF formation and climate around the Mediterranean. The consistency of the climatic signal among different pine species and areas suggests that, in the future, a large-scale network of IADFs could be developed in the Mediterranean region to study intra-annual climate variability (Campelo et al., 2013). A more detailed analysis of climatic events may detect effects on inter-annual density fluctuations as determined by a logistic model that includes the stabilized IADF frequency assessed in relation to calendar year. 
In order to understand the responses of Mediterranean pine species to climate change and which anatomical structures can be used to document it, the present work investigates: i) radial growth-climate relationships over time for $P$. halepensis, $P$. pinaster and $P$. sylvestris in Spain, ii) the presence of intra-annual density fluctuations (IADFs) on the three species and, iii) the climatic variables that are associated with the occurrence of IADFs.

\section{Materials and Methods}

Twenty-six sampling sites (8 P. halepensis sites, $8 P$. pinaster sites and $10 P$. sylvestris sites) were selected in their distribution area in Spain (Fig. 1; Table 1). Pinus halepensis sampling sites consist of an upper storey of $P$. halepensis and an understorey formed by broadleaved Mediterranean species (Quercus ilex L., Q. coccifera L. y Q. faginea Lamk.). Silviculture in the sampling area of $P$. pinaster is traditionally based on natural regeneration following a seed tree system and focused on multifunctional uses (timber, resin, recreation, etc). Pinus sylvestris sampling sites are at its southern and western distribution threshold. These dry areas of distribution of this species which usually grows in humid environments are the first places to investigate the effects of increased aridity (Martínez Vilalta and Piñol, 2002). Besides, in assessing the impact of global warming on ecosystems, any changes in tree growth are likely to occur first in those tree stands placed at the ecological boundary of the species (Tessier et al., 1997). At each sampling site, 15 dominant trees were selected. Two cores were extracted at $1.30 \mathrm{~m}$ above ground from each selected tree. The increment cores were air dried, mounted on wooden supports and dated according to standard dendrochronological techniques (Stokes and Smiley, 1968). 


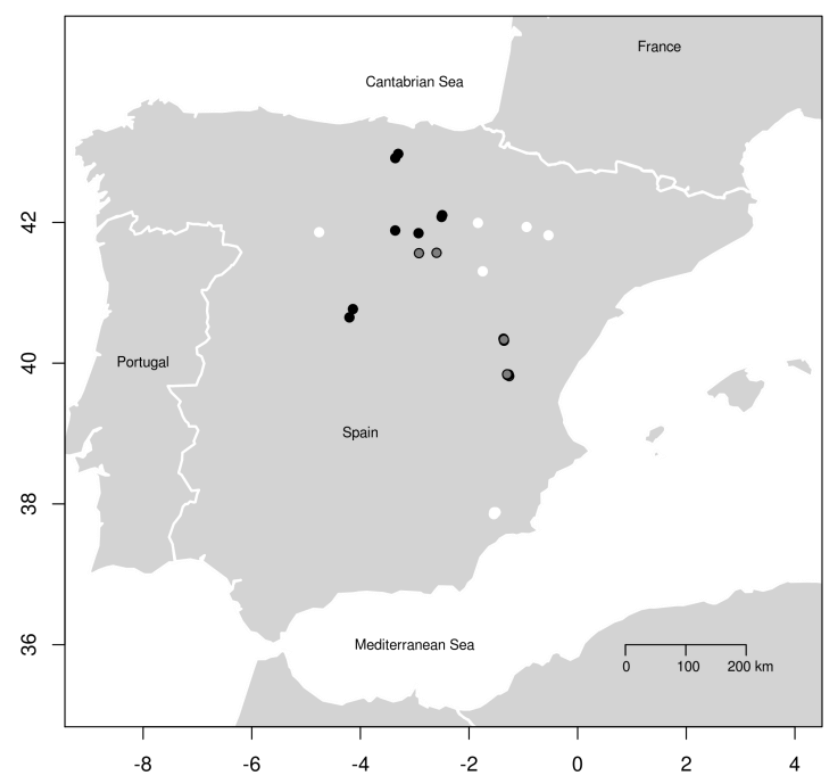

Fig. 1: Study areas of the three pine species in Spain. White: Pinus halepensis; grey: P. pinaster; black: P. sylvestris.

Absolute dating is essential for any dendroclimatological study, and it is impossible to compare climatic variables in one specific year with tree-ring growth if the individual treering series are not dated correctly (Fritts, 2001). To assess measurement and dating accuracy, the v6.06P COFECHA program (Holmes, 2001; Grissino-Mayer, 2001; available at www.ltrr.arizona.edu) was applied. This program calculates the Pearson correlation indices between the indexed tree-ring series and a master reference chronology in a series of consecutive, partially overlapped segments of a length specified by the user. According to standard dendrochronological methods, tree-ring series exhibiting correlation values with the master chronology below 0.4 were excluded.

Standardization removes geometrical and ecological trends while preserving inter-annual high-frequency variations that are presumably related to climate. To eliminate biological trends in tree-ring series and to minimize growth variations that are not shared by most trees, the v6.05P ARSTAN program (Cook and Holmes, 1984; Holmes, 2001; available at www.ltrr.arizona.edu) was used. The long-term trend was removed from each time series of ring width measurements by fitting and calculating an index defined as actual ring-width 
for each year divided by the curve-fit value. The standardized series were averaged in order to obtain a master chronology at each study site.

Table 1: Sampling sites description of Pinus halepensis, P. pinaster and P. sylvestris in Spain.

\begin{tabular}{|c|c|c|c|c|c|}
\hline Species & Code & $\begin{array}{l}\text { Altitude } \\
\quad(\mathbf{m})\end{array}$ & Time span & $\begin{array}{c}\text { Annual } \\
\text { precipitation } \\
(\mathbf{m m})\end{array}$ & $\begin{array}{c}\text { Mean monthly } \\
\text { Temperature }\left({ }^{\mathbf{o}} \mathrm{C}\right)\end{array}$ \\
\hline \multirow[t]{8}{*}{ P. halepensis } & H30101 & 811 & $1932-2008$ & 617 & 12.7 \\
\hline & H30102 & 957 & $1915-2008$ & 617 & 12.7 \\
\hline & H30103 & 1118 & 1914-2008 & 617 & 12.7 \\
\hline & H34001 & 849 & $1975-2008$ & 441 & 12.1 \\
\hline & H50009 & 976 & $1978-2008$ & 344 & 12.3 \\
\hline & H50001 & 695 & $1975-2008$ & 395 & 13.1 \\
\hline & H50101 & 535 & $1919-2007$ & 616 & 12.4 \\
\hline & H50102 & 706 & $1926-2007$ & 587 & 12.4 \\
\hline \multirow[t]{10}{*}{$P$. pinaster } & P16106 & 970 & $1880-2005$ & 901 & 8.3 \\
\hline & P16108 & 920 & $1948-2005$ & 901 & 8.3 \\
\hline & P16201 & 1078 & $1948-2005$ & 901 & 8.3 \\
\hline & P16202 & 1010 & $1978-2005$ & 901 & 8.3 \\
\hline & P16208 & 1090 & $1887-2005$ & 901 & 8.3 \\
\hline & P42002 & 1059 & $1918-2005$ & 487 & 8.3 \\
\hline & P42201 & 1012 & $1948-2005$ & 484 & 10.2 \\
\hline & P44002 & 1437 & $1846-2005$ & 563 & 10.4 \\
\hline & P44005 & 1364 & $1849-2005$ & 563 & 10.4 \\
\hline & P44204 & 1232 & 1953-2005 & 563 & 10.4 \\
\hline \multirow[t]{8}{*}{ P. sylvestris } & S05006 & 1438 & $1813-2005$ & 559 & 7.5 \\
\hline & S09005 & 888 & $1867-2005$ & 632 & 9.2 \\
\hline & S09209 & 1097 & $1848-2005$ & 487 & 10.2 \\
\hline & S09501 & 814 & $1935-2005$ & 527 & 10.3 \\
\hline & S40006 & 1440 & $1891-2005$ & 466 & 9.7 \\
\hline & $\mathrm{S} 42415$ & 1165 & $1951-2005$ & 487 & 10.2 \\
\hline & S42504 & 1431 & $1960-2005$ & 487 & 10.2 \\
\hline & S42505 & 1659 & $1946-2005$ & 487 & 10.2 \\
\hline
\end{tabular}


The accurately dated cores were visually examined for IADF using a stereomicroscope (magnification up to $25 \mathrm{x}$ ). In contrast to the annual rings, IADFs show a non-sharp transition boundary between earlywood and latewood cells (Fritts, 2001). IADFs were only counted when present in both cores in the same tree ring, and they were identified by considering the position of the density fluctuation within the ring. Only IADF type E (latewood-like cells within the earlywood) were considered for our study since IADF type L (earlywood-like cells within the latewood) were rarely present in our sample (Fig. 2).
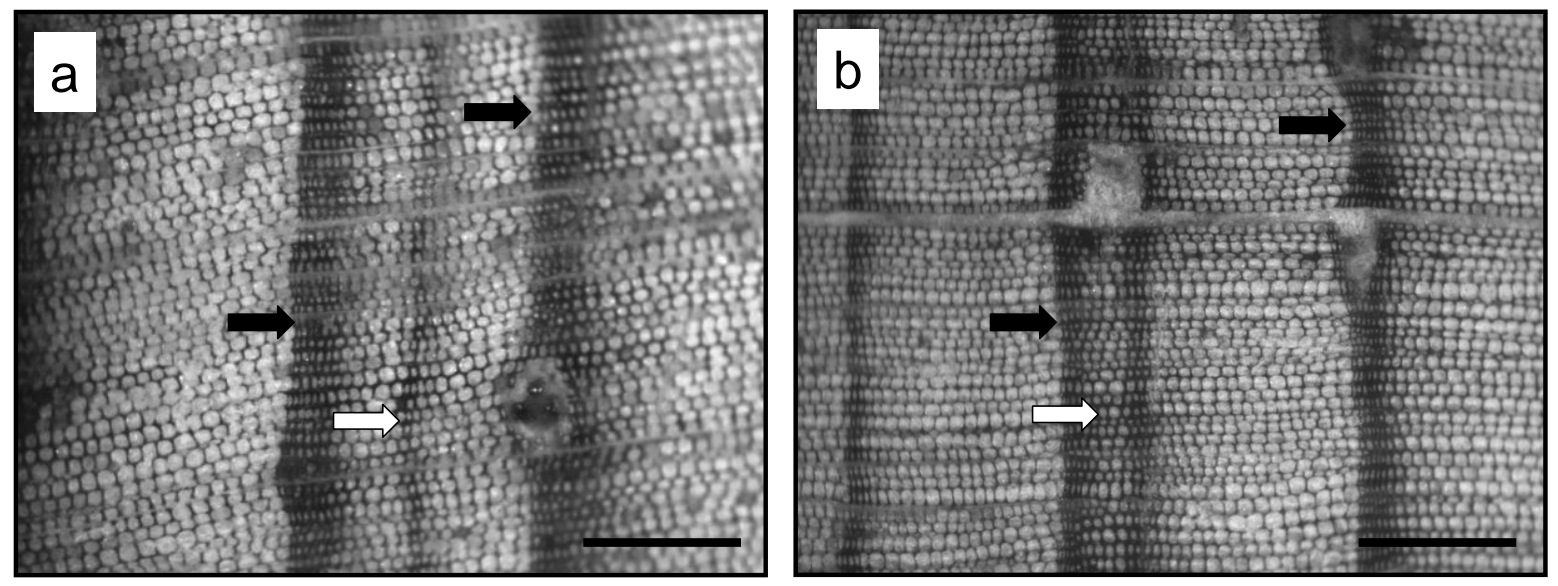

Fig. 2: Intra-annual density fluctuations (IADF) in Pinus pinaster (Bogino and Bravo, 2009). IADF type $E(a)$ : Latewood-like tracheids within the earlywood. IADF type L (b): Earlywood-like tracheids within the latewood. Annual tree rings grew from left to right. Black arrows indicate the true tree-ring boundary and white arrows the IADFs. Scale bars $1 \mathrm{~mm}$.

As the number of samples changed over time, the relative frequency was calculated with the following formula [1]:

$$
[1] \mathrm{F}=\mathrm{n} / \mathrm{N}
$$

where $\mathrm{F}$ is the relative frequency of IADF in a particular year; $\mathrm{n}$ the number of trees that formed the IADF and $\mathrm{N}$ the total number of trees analysed. The bias in the frequency was assessed by calculating the stabilized IADF frequency (f), according to the formula of Osborn et al. (1997) [2]:

[2] $f=F^{0.5}$ 
The nonlinear logistic equation form was chosen to model the probability of occurrence of IADFs [3]:

$[3] \mathrm{P}=\left(1.0+\mathrm{e}^{(-\mathrm{z})}\right)^{-1}$

where $\mathrm{P}$ is the probability of IADFs and $\mathrm{Z}=\mathrm{b} 0+\mathrm{b} 1(\mathrm{x} 1)+\mathrm{b} 2(\mathrm{x} 2)+\ldots \ldots+\mathrm{bk}(\mathrm{xk})+\varepsilon$; where $\mathrm{x} 1 ; \mathrm{x} 2 \ldots . . \mathrm{xk}$ are the climatic variables and $\mathrm{b} 0 ; \mathrm{b} 1 ; \mathrm{b} 2 \ldots . . \mathrm{bk}$ are unknown parameters of the model and $\varepsilon$ is a normal random error $\mathrm{N}(0,1)$; and $e$ is the exponential operator. The logistic equation can be formulated to accept a binary variable such as occurrence of IADFs, and the parameters can be estimated by maximum-likelihood methods. The resulting prediction is bounded by 0 and 1 . Monthly rainfall and mean monthly temperature were used as explanatory variables. The hydrological year was defined as a period of 12 months, from October of the previous year to September of the current growth year. A stepwise selection method was used to find the best model.

The alternative fits were evaluated on the basis of Akaike information criterion (AIC), the $2 *$ Log Likelihood, the area under the receiver operating characteristic (ROC) curve, and the expected behavior - as indicated by the signs of the estimated parameters. ROC curve is displayed for the models and the area underneath was calculated as a value of the accuracy of the model. Value greater than 0.80 indicates an excellent discrimination (Hosmer and Lemeshow, 2000). This curve relies on false/true positive/negative tests, and the sensitivity is indicated by the proportion of correctly classified events and the specificity by the proportion of correctly classified non-events (Hair et al., 1998). Logistic regression was previously successfully used to estimate the probability of occurrence of IADFs in $P$. pinaster subsp. mesogenesis and P. halepensis in Spain (Bogino and Bravo, 2009; Olivar et al., 2012). PROC LOGISTIC of SAS 9.1 (SAS Institute Inc. 2004) was used to fit the model.

We grouped the climatic variables (monthly precipitation and mean monthly temperature) recorded at the closest meteorological stations (Agencia Estatal de Meteorología, Spain) in climatic seasons: winter previous to the growing season (December-February), spring (March-May), summer (June-August) and autumn (September-November). The climatic data were regressed against ring-width indices and the stabilized IADF frequency. In order 
to calculate Pearson correlation coefficients and response functions we used DENDROCLIM 2002 (Biondi and Waikul, 2004). Moving correlation function was used to test stationarity and consistency through time with a 20 -year interval.

\section{Results}

Precipitation is the main factor influencing tree growth of the three Mediterranean tree species. Bootstrap correlation significant values $(\mathrm{p}<0.5)$ between radial growth of $P$. halepensis, $P$. pinaster and P. sylvestris and seasonal climate is shown in Table 2. Despite site variability, there was a correspondence between the higher correlation values and seasonal climate indicating that wet periods during winter previous to the growth season and spring induced high growth rates on $P$. halepensis and $P$. pinaster, while the growth of $P$. sylvestris was mostly influenced by summer precipitation. Pinus pinaster showed the highest correlations $(\mathrm{p}<0.005)$ between precipitation and growth $(\mathrm{r}=0.12$ in average $)$.

The analysis of the influence of the climatic variables over time on P. halepensis shows that this positive influence of winter, spring and summer precipitation on its growth began increasing in the 1990s decade. During that period, spring temperature shifted its influence from negative to positive, while summer temperature shifted from positive to negative (Fig. 3a). In the case of $P$. pinaster, the greatest increase in the influence of the climatic variables on growth occurred during the 1970s, when spring precipitation became the dominant influence followed by summer and winter precipitation. Also during that period, winter temperature increased its positive influence, while the influence of spring, summer and autumn temperature became negative (Fig. 3b). Summer precipitation had the highest correlation values $(0.33)$ with $P$. sylvestris, and they remained essentially stable during the study period. Winter and spring temperature also had a positive influence on its growth, while summer temperature shifted its influence from positive to negative around 1980 (Fig. $3 c)$. 
Table 2: Bootstrap correlation significant values $(p<0.5)$ between radial growth of Pinus halepensis, P. pinaster and P. sylvestris and seasonal climate (mean temperature and precipitation). White: 0-0.24; light grey: 0.25-0.49; dark grey: 0.5-0.74; black: 0.75-1.

\begin{tabular}{|c|c|c|c|c|c|c|c|c|c|}
\hline \multirow{2}{*}{ Species } & \multirow{2}{*}{ Site } & \multicolumn{4}{|c|}{ Temperature } & \multicolumn{4}{|c|}{ Precipitation } \\
\hline & & Win. & Spr. & Sum. & Aut. & Win. & Spr. & Sum. & Aut. \\
\hline \multirow[t]{8}{*}{ P. halepensis } & H30101 & & & & & & + & & + \\
\hline & H30102 & & - & & & & + & & \\
\hline & H30103 & & & & & + & + & & \\
\hline & H34001 & + & & - & & + & + & & - \\
\hline & H50009 & & & & & + & + & + & \\
\hline & H50001 & & & & & & & & \\
\hline & H50101 & & & - & & & & & \\
\hline & H50102 & & & & & & & & \\
\hline \multirow[t]{10}{*}{$P$. pinaster } & P16106 & & & & - & + & + & & \\
\hline & P16108 & & & & - & + & + & & \\
\hline & P16201 & + & & & - & + & + & & \\
\hline & P16202 & & & - & & & + & + & \\
\hline & P16208 & + & & & & & & & \\
\hline & P42002 & & & & & & & + & \\
\hline & P42201 & & & + & & & & & \\
\hline & P44002 & & & & & + & + & + & \\
\hline & P44005 & & & & & + & + & & \\
\hline & P44204 & & & & & + & + & & \\
\hline \multirow[t]{8}{*}{ P. sylvestris } & S05006 & & & & & & & + & \\
\hline & S09005 & & & & & & & & \\
\hline & S09209 & + & + & & & & & + & - \\
\hline & S09501 & + & & & & - & & + & \\
\hline & S40006 & & & - & & & & & \\
\hline & S42415 & & & & & & & + & \\
\hline & S42504 & & + & & & & & + & \\
\hline & $\mathrm{S} 42505$ & & & & & & & + & \\
\hline
\end{tabular}




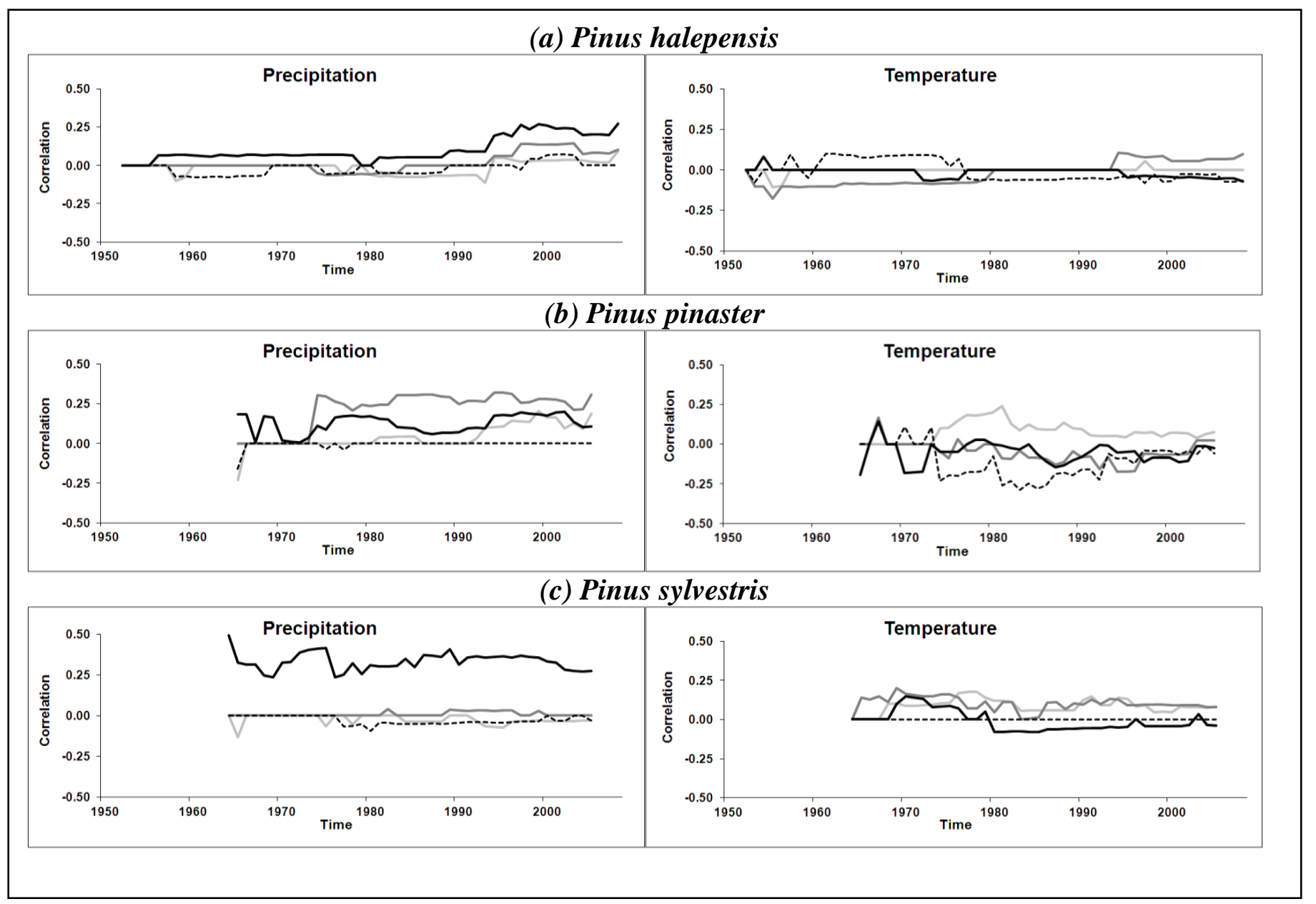

Fig. 3: Influence of the climatic variables (precipitation and mean temperature) over time on radial growth of Pinus halepensis, P. pinaster and P. sylvestris ( $p<0.005)$. Light grey: winter; dark grey: spring; black: summer; dashed line: autumn.

$P$. pinaster had the highest accumulated mean stabilized IADF frequency (0.12), followed by $P$. halepensis (0.03). The logistic function estimated that the occurrence of IADFs is mainly influenced by precipitation on the three species. Precipitation in the winter previous to the growing season and spring was associated with the occurrence of IADFs in $P$. halepensis, while this influence was delayed in the case of P. pinaster, influenced by spring and early summer precipitation. Both species showed a negative influence of precipitation in July. The IADF frequency of $P$. sylvestris was the lowest of the three species (0.004). IADF frequency in relation to calendar year (Fig. 4) showed an increase in IADFs in the second half of the century. The years 1961, 1983, 1995 and 1999 had a higher occurrence of IADFs, with a stabilized frequency higher than 0.8 . 


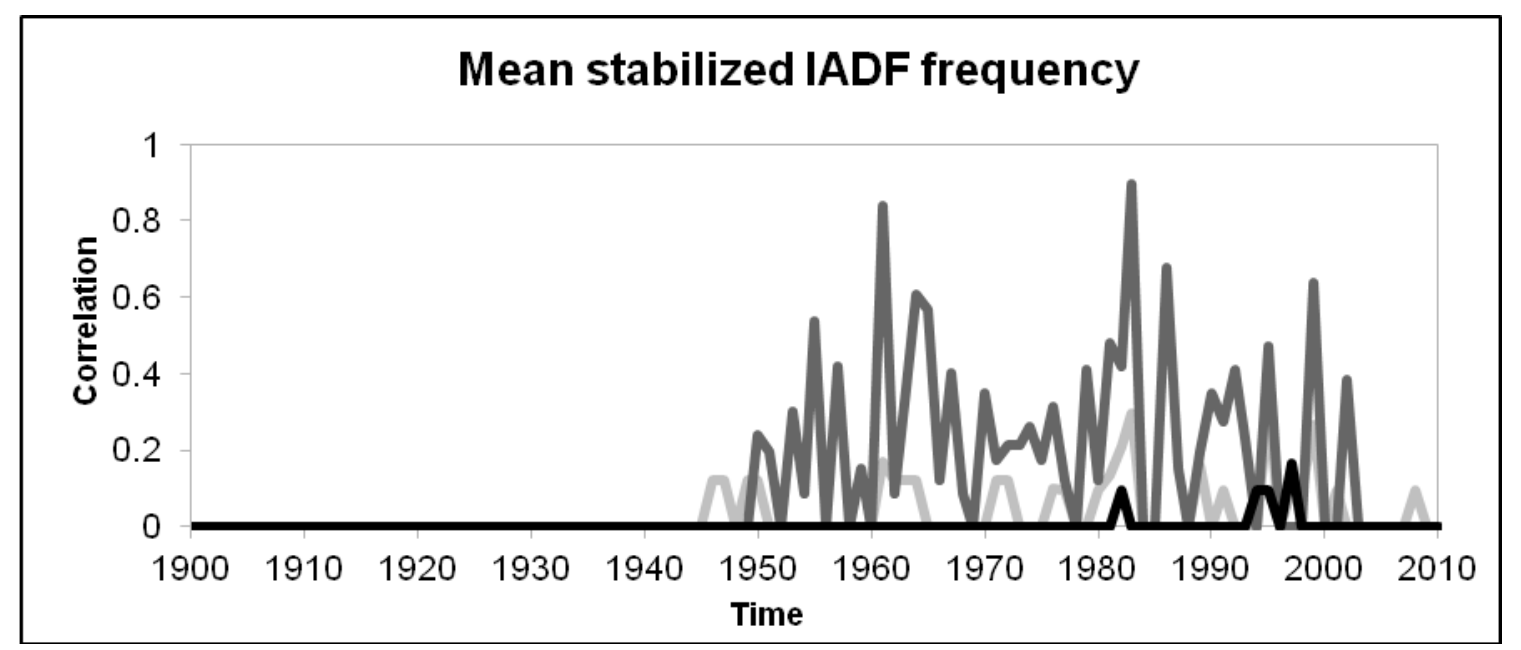

Fig. 4: Accumulated mean stabilized IADF frequency in relation to calendar year of the three species. White: Pinus halepensis (1914-2008), grey: P. pinaster (1880-2005), black: P. sylvestris (1813-2005).

\section{Discussion}

\section{Climate-growth relationship along time}

Precipitation is the main factor influencing tree growth of pine species in semiarid Mediterranean conditions (Raventós et al., 2001). In our study sites, the growth of $P$. halepensis, $P$. pinaster and $P$. sylvestris is mainly controlled by precipitation at different times of the year. Despite the lack of biological significance of some low correlation values and the site variability, higher correlation values between seasonal climatic conditions and species reflect differences in the influence of climatic conditions between species. Winter and spring precipitation is related positively with tree-ring growth in $P$. halepensis and $P$. pinaster, while the growth of $P$. sylvestris is mostly influenced by summer precipitation. These results are consistent with those of previous studies in P. halepensis in Greece and Spain (Papadopoulos et al., 2008; Olivar et al., 2012), P. pinaster in Portugal (Vieira et al., 2010; Campelo et al., 2013) and central Spain (Bogino and Bravo, 2008), and P. sylvestris at its southern and western distribution limits (Bogino et al., 2009).

However, the influence of these climatic variables on the growth of these species changed over the studied period. The positive influence of winter and spring precipitation on $P$. halepensis growth increased beginning in the 1990s and the positive influence of spring 
precipitation on $P$. pinaster growth increased beginning in the 1970 s, while the positive influence of summer precipitation on $P$. sylvestris growth remained stable. These results agree with previous reports on pine species in the Mediterranean area, which suffered a change in growth response to climatic conditions in the second half of the 20th century (Andreu et al., 2007; Bogino and Bravo, 2008; Vieira et al., 2010; Campelo et al., 2013).

Global studies around the Mediterranean basin indicate that winter and spring precipitation increased and summer precipitation decreased during the second-half of the twentieth century (Bradley et al., 1987; Maheras, 1988; Díaz et al., 1989). Mediterranean pines evolved during the Pliocene under tropical-like climate, before the onset of the Mediterranean climate, as a component of the pre-Mediterranean Arcto-Tertiary flora (Verdú et al., 2003; Petit et al., 2005). This species survived to a past gradual increase of aridity during the transition to Mediterranean conditions, which may have led to its characteristic growth plasticity (Chambel et al., 2007). Mediterranean Pinus species are considered well adapted to withstand drought by reducing growth as water availability decreases and increasing growth as conditions become favourable (Rathgeber et al., 2005; De Luis et al., 2007; Camarero et al., 2010; Pasho et al., 2012). This increase of winter and spring precipitation combined with the increasingly harsh climatic conditions during summer may have enhanced the importance of precipitation at the beginning of the growing season on the growth of species subject to higher drought stress conditions during summer, such as $P$. halepensis and $P$. pinaster. On the other hand, $P$. sylvestris, growing under higher water availability during the whole year, didn't suffer that swift in the influence of the climatic variables.

\section{IADF occurrence}

The occurrence of IADFs is mainly influenced by precipitation in these species. IADFs may appear at different development phases of the tree-ring formation depending on the time of the year when the stress conditions occurred. IADF type $\mathrm{E}$ is triggered by dry periods during spring and early summer. In contrast, IADF type $\mathrm{L}$ is triggered by precipitation during late summer and (or) early autumn (Wimmer et al., 2000). Previous studies in the Mediterranean area showed a high frequency of IADFs in latewood (de Luis et al., 2007; Vieira et al., 2010; Rozas et al., 2011; Campelo et al., 2013; Novak et al., 
2013). However, the low frequency of IADF type L and the high frequency of IADF type $\mathrm{E}$ observed in our samples indicate a higher occurrence of water stress episodes inhibiting cell division and enlargement during the first part of the growing season. The ability of species to produce different types and forms of cells in different periods may also be interpreted as an important adaptation of trees for maintaining the balance among the capacity to conduct water, resistance to cavitation and mechanical stability (Novak et al., 2013).

The formation of IADFs is triggered by above-average precipitation in the previous winter and spring in $P$. halepensis and in spring and early summer in $P$. pinaster and negatively influenced by precipitation in July. These climatic conditions (precipitation at the beginning of the growing season and summer droughts) have been increasingly favoured over the second half of the $20^{\text {th }}$ century, explaining the increasing occurrence of IADFs our study area. This result agrees with previous studies that found an increase in IADF frequencies after 1980 in P. pinaster in Spain (Bogino and Bravo, 2009) and Portugal (Vieira et al., 2010; Campelo et al., 2013). Despite being at its southern distribution threshold, where a species that usually grows in humid environments could suffer from the effects of increased aridity (Martínez Vilalta and Piñol, 2002), P. sylvestris showed the lowest IADF frequency of the three species on our sample. As pointed out by Battipaglia et al., 2010, the frequency and the triggering climatic factors promoting different anatomical characteristics may vary among populations, depending on different environmental conditions.

\section{Conclusions}

Precipitation is the main factor influencing tree growth and its fluctuation determines IADF occurrence in the three pine species. Pinus pinaster showed the highest correlations between precipitation and growth. Wet periods during winter previous to the growth season and spring induced higher growth rates in $P$. halepensis and $P$. pinaster, while the growth of $P$. sylvesteris was mostly influenced by summer precipitation. Precipitation in the winter previous to the growing season and spring was associated with the occurrence of IADFs in $P$. halepensis, while this influence was delayed in the case of $P$. pinaster, influenced by spring and early summer precipitation. However, the influence of these climatic variables on the growth of these species changed over the studied period. The increase of winter and spring precipitation combined with the increasingly harsh climatic conditions during 
summer in the second half of the $20^{\text {th }}$ century may have enhanced the importance of precipitation at the beginning of the growing season on the growth of species subject to higher drought stress conditions during summer, such as $P$. halepensis and $P$. pinaster and the occurrence of IADFs increased. The incorporation of special ring features such as IADFs and their association with climatic variables in any dendrochronological study provides a useful proxy for complementing and enhancing the dendroclimatological data.

\section{Acknowledgements}

The authors wish to thank the COST-Action FP0703 "Expected Climate Change and Options for European Silviculture" (ECHOES), the Spanish National Project AGL-200765795-C02-01 and the Spanish Meteorological Agency for providing the meteorological data.

\section{References}

Andreu, L., Gutiérrez, E., Macias. M,, Ribas, M., Bosch. O,, Camarero. J.J., 2007. Climate increases regional tree-growth variability in Iberian pine forests. Glob Change Biol 13(4): 804-815.

Battipaglia, G., De Micco, V., Brand, W.A., Linke, P., Aronne, G., Saurer, M., Cherubini, P., 2010. Variations of vessel diameter and $\delta 13 \mathrm{C}$ in false rings of Arbutus unedo L. reflect different environmental conditions. New Phytol 188(4): 1099-1112.

Bender, B.J., Mann, M., Backofen, R., Spiecker, H., 2012. Microstructure alignment of wood density profiles: an approach to equalize radial differences in growth rate. Trees 26: 1267-1274.

Biondi, F., Waikul, K., 2004. DENDROCLIM2002: a C++ program for statistical calibration of climate signals in tree-ring chronologies. Comput Geosci 30: 303-311.

Blanco, E., Casado, M., Costa, M., Escribano, R., Gracía Antón, M., Génova, M., Gómez Manzaneque, G., Gómez Manzanaque, F., Moreno, J., Morla, C., Regato, P., Sainz Ollero, H., 1997. Los bosques ibéricos, Editorial Planeta, Barcelona, Spain. 
Bogino, S., Bravo, F., 2008. Growth response of Pinus pinaster ait. to climatic variables in central Spanish forests. Ann For Sci 68: 506-518.

Bogino, S., Bravo, F., 2009. Climate and intra-annual density fluctuations in Pinus pinaster subsp. Mesogeensis in Spanish woodlands. Can J For Res 39(8): 1557-1565.

Bogino, S., Fernández Nieto, M.J., Bravo, F., 2009. Climate effect on radial growth of Pinus sylvestris at its southern and western distribution limits. Silva Fenn 43(4): 609-623.

Bradley, R.S., Diaz, H.F., Eischeid, J.K., Jones, P.D., Kelly, P.M., Goodess, C.M., 1987. Precipitation fluctuations over Northern Hemisphere land areas since the mid-19th century. Science 237: 171-175.

Camarero, J.J., Olano, J.M., Parras, A., 2010. Plastic bimodal xylogenesis in conifers from continental Mediterranean climates. New Phytol 185: 471-480.

Campelo, F., Vieira, J., Nabais, C., 2012. Tree-ring growth and intra-annual density fluctuations of Pinus pinaster responses to climate: does size matter? Trees DOI 10.1007/s00468-012-0831-3.

Chambel, M.R., Climent, J., Alía, R., 2007. Divergence among species and populations of Mediterranean pines in biomass allocation of seedlings grown under two watering regimes. Ann For Sci 64: 87-97.

Chbouki, N., Stockton, C.W., Myers, D., 1995. Spatio-temporal patterns of drought in Morocco, Int J Climatol 15: 187-205.

Cook, E.R., Holmes, R.L., 1984. Program Arstan users manual. Laboratory of Tree-Ring Research, University of Arizona, Tucson, USA.

De Luis, M., Gričar, J., Čufar, K., Raventós, J., 2007. Seasonal dynamics of wood formation in Pinus halepensis from dry and semi-arid ecosystems in Spain. IAWA J 28: $389-404$. 
De Luis, M., Novak, K., Raventós, J., Gričar, J., Prislan, P., Čufar, K., 2011. Climate factors promoting intra-annual density fluctuations in Aleppo pine (Pinus halepensis) from semiarid sites. Dendrochronologia 29: 163-169.

De Micco, V., Saurer, M., Aronne, G., Tognetti, R., Cherubini, P., 2007. Variations of wood anatomy and $\delta 13 \mathrm{C}$ within tree rings of coastal Pinus pinaster Ait. showing intraannual density fluctuations. IAWA J 28(1): 61-74.

De Micco, V., Battipaglia, G., Brand, W.A., Linke, P., Saurer, M., Aronne, G., Cherubini, P., 2012. Discrete versus continuous analysis of anatomical and $\delta 13 \mathrm{C}$ variability in tree rings with intra-annual density fluctuations. Trees 26: 513-524. DOI 10.1007/s00468-0110612-4.

Díaz, H.F., Bradley, R.S., Eischeid, J.K., 1989. Precipitation fluctuations over global land areas since the late 1800s. J Geophys Res 94: 1195-1210.

Edmondson, J., 2010. The Meteorological Significance of False Rings in Eastern Redcedar (Juniperus virginiana L.) from the Southern Great Plains, USA. Tree-Ring Res 66: 19-33.

Fritts, H.C., 2001. Tree rings and climate. The Blackburn press, London.

Grissino-Mayer, H.D., 2001. Evaluating crossdating accuracy: a manual and tutorial for the computer program Cofecha. Tree-Ring Res 57: 205-221.

Hair, J.E., Anderson, R.E., Tatham, R.L., Black, W.C., 1998. Multivariate data analysis. 5th ed. Prentice Hall, Upper Saddle River, New Jork, Usa.

Harley, G.L., Grissino-Mayer, H.D., Franklin, J.A., Anderson, C., Köse, N., 2012. Cambial activity of Pinus elliottii var. densa reveals influence of seasonal insolation on growth dynamics in the Florida Keys. Trees. DOI:10.1007/s00468-012-0719-2.

Hosmer, D.W., Lemeshow, S., 2000. Applied logistic regression. Wiley. New York.

Holmes, R.L., 2001. Dendrochronology program library. LLaboratory of Tree-Ring Research, University of Arizona, Tucson, USA. 
Kaenel, M., Schweingruber, F.H., 1995. Multilingual Glossary of Dendrochronology. Paul Haupt publishers Berne, Stuttgart, Vienna.

Lavorel, S., Canadell, J., Rambla, S., Terradas, J., 1998. Mediterranean terrestrial ecosystems: research priorities on global change effect. Global Ecol Biogeogr 7: 157-166.

Lev-Yadun, S., Liphschitz, N., Waisel, Y., 1981. Dendrochronological investigations in Israel: Pinus halepensis Mill. the oldest living pines in Israel, La Yaaran, 31(1-4): 49-52 and 2-8.

Lupi, C., Morin, H., Deslauriers, A., Rossi, S., 2010. Xylem phenology and wood production: resolving the chicken-or-egg dilemma. Plant Cell Environ 33: 1721-1730.

Maheras, P., 1988. Changes in precipitation conditions in the Western Mediterranean over the last century. J Climate 8: 179-189.

Martínez-Vilalta, J., Piñol, J., 2002. Drought-induced mortality and hydraulic architecture in pine populations of the NE Iberian Peninsula. For Ecol Manage 161: 247-256.

Martrat, B., Grimalt, J.O., Lopez-Martinez, C., Cacho, I., Sierro, F.J., Flores, J.A., Zahn, R., Canals, M., Curtis, J.H., Hodell, D.A., 2004. Abrupt temperature changes in the Western Mediterranean over the past 250,000 years. Science 306 (5702): 1762-1765.

Moreno-Gutiérrez, C., Battipaglia, G., Cherubini, P., Saurer, M., Nicolás, E., Contreras, S., Querejeta, J.I., 2012. Stand structure modulates the long-term vulnerability of Pinus halepensis to climatic drought in a semiarid Mediterranean ecosystem. Plant Cell Environ 35: 1026-1039.

Novak, K., de Luis, M., Raventós, J., Čufar, K., 2013. Climatic signals in tree-ring widths and wood structure of Pinus halepensis in contrasted environmental conditions. Trees DOI 10.1007/s00468-013-0845-5.

Olivar, J., Bogino, S., Spiecker, H., Bravo, F., 2012. Climate impact on growth dynamic and intra-annual density fluctuations in Aleppo pine (Pinus halepensis) trees of different crown classes. Dendrochronologia 30 Issue 1: 35-47. 
Osborn, T.J., Briffa, K.R., Jones, P.D., 1997. Adjusting variance for sample-size in treering chronologies and other regional mean time series. Dendrochronologia 15: 1-10.

Paiva, J.A.P., Garnier-Géré, P.H., Rodrigues, J.C., Alves, A., Santos, S., Graça, J., Le Provost, G., Chaumeil, G., Da Silva-Perez, D., Bosc, A., Fevereiro, P., Plomion, C., 2008. Plasticity of maritime pine (Pinus pinaster) wood-forming tissues during a growing season. New Phytol 179: 1080-1094.

Panayotov, M.P., Zafirov, N., Cherubini, P., 2013. Fingerprints of extreme climate events in Pinus sylvestris tree rings from Bulgaria. Trees 27: 211-227.

Papadopoulos, A., Tolica, K., Pantera, A., Maheras, P., 2008. Investigation of the annual variability of the Aleppo pine tree-ring width: the relationship with the climatic conditions in the Attica basin. Global Nest J.

Pasho, E., Camarero, J.J., Vicente-Serrano, S.M., 2012. Climatic impacts and drought control of radial growth and seasonal wood formation in Pinus halepensis. Trees DOI 10.1007/s00468-012-0756-X.

Petit, R.J., Hampe, A., Cheddadi, R., 2005. Climate change and tree phylogeography in the Mediterranean. Taxon 54: 877-885.

Raventós, J., de Luís, M., Gras, M., Cufar, K., González-Hidalgo, J., Bonet, A., Sánchez, J., 2001. Growth of Pinus pinea and Pinus halepensis as affected by dryness, marine spray and land use changes in a Mediterranean semiarid ecosystem. Dendrochronologia 19: 211-220.

Rathgeber, C., Misson, L., Nicault, A., Guiot, J., 2005. Bioclimatic model of tree radial growth: application to French Mediterranean Aleppo pine forests. Trees 19: 162-176.

Rozas, V., García-González, I., Zas, R., 2011. Climatic control of intra-annual wood density fluctuations of Pinus pinaster in NW Spain. Trees 25: 443-453.

Safar, W., 1994. Contribution a l'étude dendroécologique du pin d'Alep (Pinus halepensis Mill.) dans une région semi-aride d'Algérie: L'Atlas Saharien (Ouled Nail - Aurès Honda). Thèse Doc. Univ. Aix-Marseille III 215 P. 
Sas Institute inc., 2004. Sas/stat versión 9.1, user’s guide. Cary. NC. USA.

Stokes, M., Smiley, T., 1968. An introduction to tree-ring dating, University of Arizona press, Tucson, USA.

Schweingruber, F.H., 1993. Trees and wood in dendrochronology. Springer Series in Wood Science. Springer-Verlag. Berlin, Germany.

Tardif, J., Camarero, J.J., Ribas, M., Gutiérrez, E., 2003. Spatiotemporal variability in radial growth of trees in the Central Pyrenees: climatic and site influences. Ecol Monogr 73: $241-257$.

Tessier, L., Guibal, F., Schweingruber, F., 1997. Research strategies in dendroecology and dendroclimatology in mountain environments. Clim Change 36: 499-517.

Verdú, M., Dávila, P., García-Fayos, P., Flores-Hernández, N., Valiente-Banuet, A., 2003. 'Convergent'" traits of Mediterranean woody plants belong to pre-Mediterranean lineages. Biol J Linn Soc 78: 415-427.

Vieira, J., Campelo, F., Nabais, C., 2010. Intra-annual density fluctuations of Pinus pinaster are a record of climatic changes in the western Mediterranean region. Can J For Res 40: 1567-1575.

Wimmer, R., Strumia, G., Holawe, F., 2000. Use of false rings in Austrian pine to reconstruct early growing season precipitation. Can J For Res 30: 1691-1697.

Xoplaki, E., Luterbache, J., Gonzalez-Rouco, J.F., 2006. Mediterranean summer temperature and winter precipitation, large scale dynamics, trends. Il Nuovo Cimento C 29(1): 45-54. 


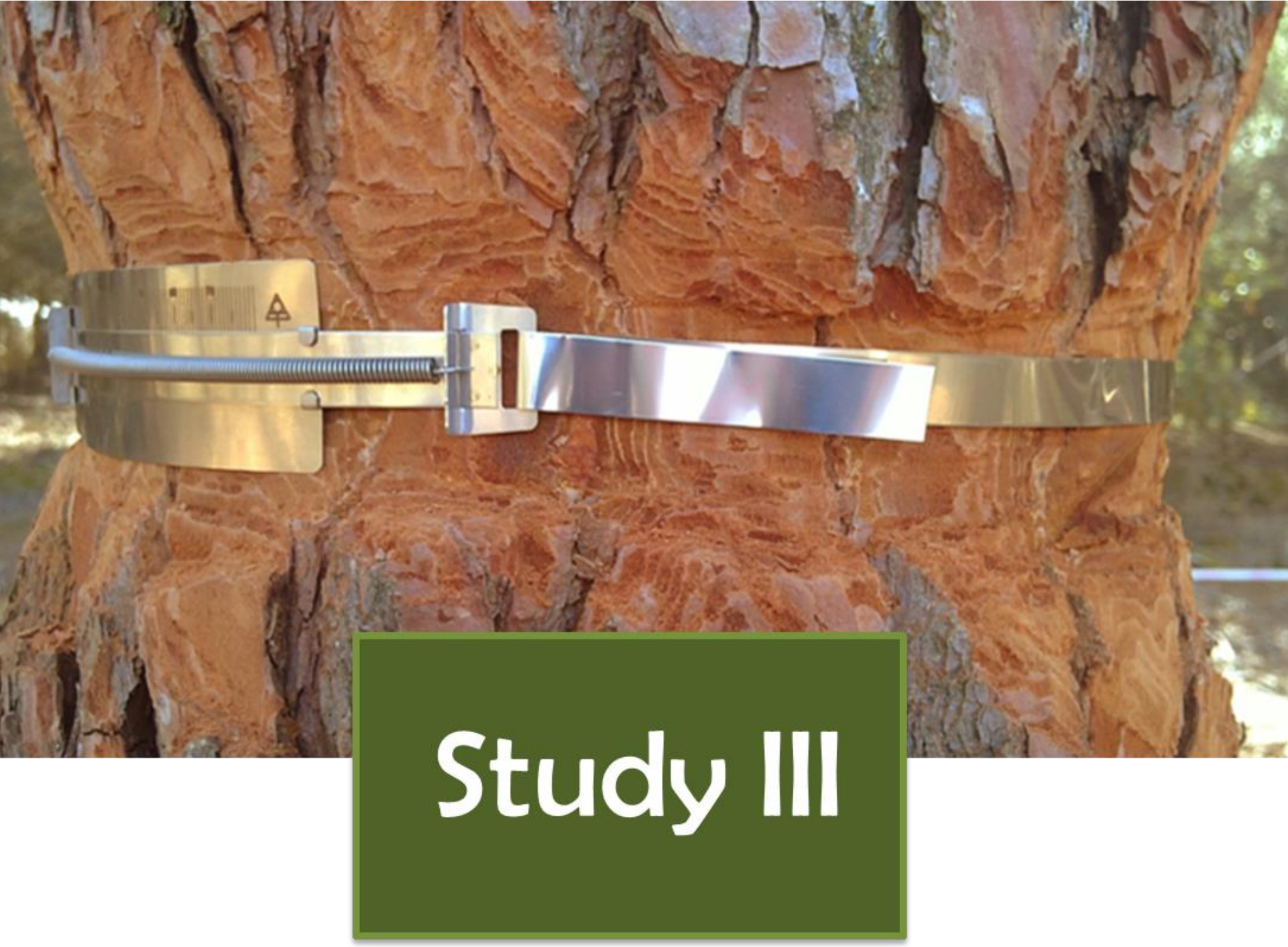

Thinning has a positive effect on growth dynamics and growth-climate relationships in Aleppo pine (Pinus halepensis) trees of different crown classes

* Olivar, J., Bogino, S., Rathgeber, C.B.K., Bonnesoeur, V., Leporati, J., Ordoñez, C., Bravo, F., 2013. Thinning has a positive effect on growth dynamics and growth-climate relationships in Aleppo pine (Pinus halepensis) trees of different crown classes. Accepted with major revision in Annals of Forest Science. 
Olivar (2013) 


\title{
Thinning has a positive effect on growth dynamics and growth-climate relationships in Aleppo pine (Pinus halepensis) trees of different crown classes
}

Jorge Olivar ${ }^{1,4}$, Stella Bogino ${ }^{2}$, Cyrille Rathgeber ${ }^{3}$, Vivien Bonnesoeur ${ }^{3}$, Cristóbal Ordoñez $^{1,4}$, Felipe Bravo ${ }^{1,4}$

${ }^{1}$ Sustainable Forest Management Research Institute Universidad de Valladolid \& INIA. Avda. de Madrid 44. 34071, Palencia, Spain

${ }^{2}$ Departamento de Ciencias Agropecuarias. Facultad de Ingeniería y Ciencias Agropecuaria. Universidad Nacional de San Luis. Avda. 25 de Mayo 384. 5730 Villa Mercedes, San Luis, Argentina

${ }^{3}$ INRA, UMR 1092 LERFOB, F-54280 Champenoux, France

${ }^{4}$ Departamento de Producción Vegetal y Recursos Forestales, Universidad de Valladolid, Avda. de Madrid 44. 34004 Palencia, Spain

\begin{abstract}
- Context Modification of stand density by thinning may buffer the response of tree growth and vigor to changes in climate by modulating soil water availability.

- Aims We tested the impact of thinning intensity on cambial growth of Aleppo pine (Pinus halepensis L.) under semi-arid, mediterranean conditions.

- Methods A multiple thinning experiment was established on an Aleppo pine plantation in Spain. We analysed the stem growth dynamics of two different crown classes under four different thinning intensities (15\%, 30\% and 45\% removal of the basal area) for two years based on biweekly band dendrometer recordings. Local relative extractable soil water was derived from the use of a water balance model Biljou@ $\subseteq$ and used as an explanatory variable.
\end{abstract}

- Results Radial growth was mainly controlled by soil water availability during the growing season and differed by crown class. The growth rates of dominant trees were significantly higher than the growth rates of suppressed trees. $30 \%$ and $45 \%$ removal of the basal area produced a growth release in both dominant and suppressed trees that did not occur under less intense thinning treatments. 
- Conclusions Soil water availability was the main driver of radial growth during the growing season. Forest management confirmed its value for ameliorating the effects of water limitations on individual tree growth. These results may help managers with understanding how altering stand dynamics will differentially affect climate-responses of Aleppo pine trees, promoting forests that are resilient to future climatic conditions.

\section{Key words}

Forest management, stand density, dendrometer, dominant, suppressed.

\section{Introduction}

In coastal Mediterranean areas, with mild winters and dry summers, cold season growth dormancy may not occur and, consequently, cambial activity is likely continuous (de Luis et al. 2007). However, in inland areas with continental Mediterranean climate, plants endure double climatic stress, caused by low winter temperatures and summer drought (Mitrakos 1980). As a result, optimal growth conditions are split into two mild periods with higher rainfall (spring and autumn), which suggest a bimodal pattern of cambial activity (Camarero et al. 2010). Pine stands are the most extensive coniferous forests in the Mediterranean zone, and Aleppo pine (Pinus halepensis Mill.) is one of the dominant tree species in the Western Mediterranean Basin and the most ecologically important species in semi-arid woodlands (Néeman and Trabaud 2000). Growth rates of P. halepensis may be expected to follow the bimodal pattern described above for trees growing in a continential Mediterranean climate, with maximum values in spring and autumn when precipitation is high and temperatures are mild.

In the Mediterranean climate, water is considered to be the most limiting resource for plant growth (Specht 1981). Nevertheless, trees of different sizes and crown classes compete differently for light, water and other resources within a stand (Peet and Christensen 1987; Orwig and Abrams 1997). Radial growth responses to climate vary considerably according to local stand density and crown class in areas where water is limiting (Linares et al. 2009). Therefore, contrasting growth responses to climate among trees in different crown classes might be particularly relevant for understanding the dynamics of forests dominated by 
species that are highly sensitive to drought stress (Adams and Kolb 2004).

Climate change models project a decrease in annual mean precipitation and rising air temperatures over the Mediterranean Basin for the twenty-first century leading to an increase in evapotranspiration (Parry et al. 2007). If water is a limiting resource, as it is predicted to be, one of the most important measures that forest managers have to moderate the influence of climate on tree growth within stands is to thin to residual stand densities that make more water available for the remaining trees (Martín-Benito et al. 2010).

Although forest managers rely heavily on the use of silvicultural treatments that manipulate stand structure and stand dynamics to modify responses to climate change, few studies have directly assessed the effects of stand structure or canopy position on climate-growth relationships (Carnwath et al. 2012). The effect of different silvicultural treatments and stand densities on tree growth response to climate is likely to be a key aspect for influencing forest preservation, particularly in the driest sites (Gea-Izquierdo et al. 2009). The influence of stand density on tree response to climate and drought is not a straightforward issue, since different approaches (e.g. ecophysiological, dendroecological, growth modelling) might give different insights (Misson et al. 2003; Moreno and Cubera 2008).

Short term data on growth dynamics are required to understand growth responses in relation to climatic variability at short time scales. Dendrometers are a valuable tool for these studies since they provide short-term measurements of radial fluctuations in relation to climate without disturbing the cambium. Here, we analysed the stem growth dynamics of P. halepensis of two different crown classes under four different thinning intensities for two years based on biweekly band dendrometer recordings. We expected that short-term variations in climatic factors and water availability were reflected in the entire growth profile. The following hypothesis were tested: (i) soil water content is the main climatic driver of intra-annual variation in growth of $P$. halepensis at our site, representing semi-arid Mediterranean environments, (ii) suppressed trees are more affected by water stress than dominant trees and (iii) the reduction of stand density through thinning stimulates diameter growth responses that offset declines expected under more severe water limitation. 


\section{Materials and Methods}

\section{Species and study site}

P. halepensis is one of the most studied Mediterranean trees. Forests dominated by this species provide a valuable system to explore how growth measured at different time scales is constrained by climate (Pasho et al. 2012) and it is considered well adapted to withstand drought by reducing growth as water availability decreases (Rathgeber et al. 2005; de Luis et al. 2007; Camarero et al. 2010; Pasho et al. 2012). The study site is located in a 60-yearold P. halepensis plantation in the north of the Spanish Meseta (Fig. 1). The area is characterized by a continental Mediterranean climate, with low winter temperatures and summer droughts. Mean annual temperature is $11.3{ }^{\circ} \mathrm{C}$ and average annual precipitation is $418 \mathrm{~mm}$ for the last thirty years. The climatic conditions in 2011 and 2012 were among the driest in the late 20th century in Spain. Total annual rainfall was 245 and $244 \mathrm{~mm}$ respectively ( $40 \%$ lower than the average).

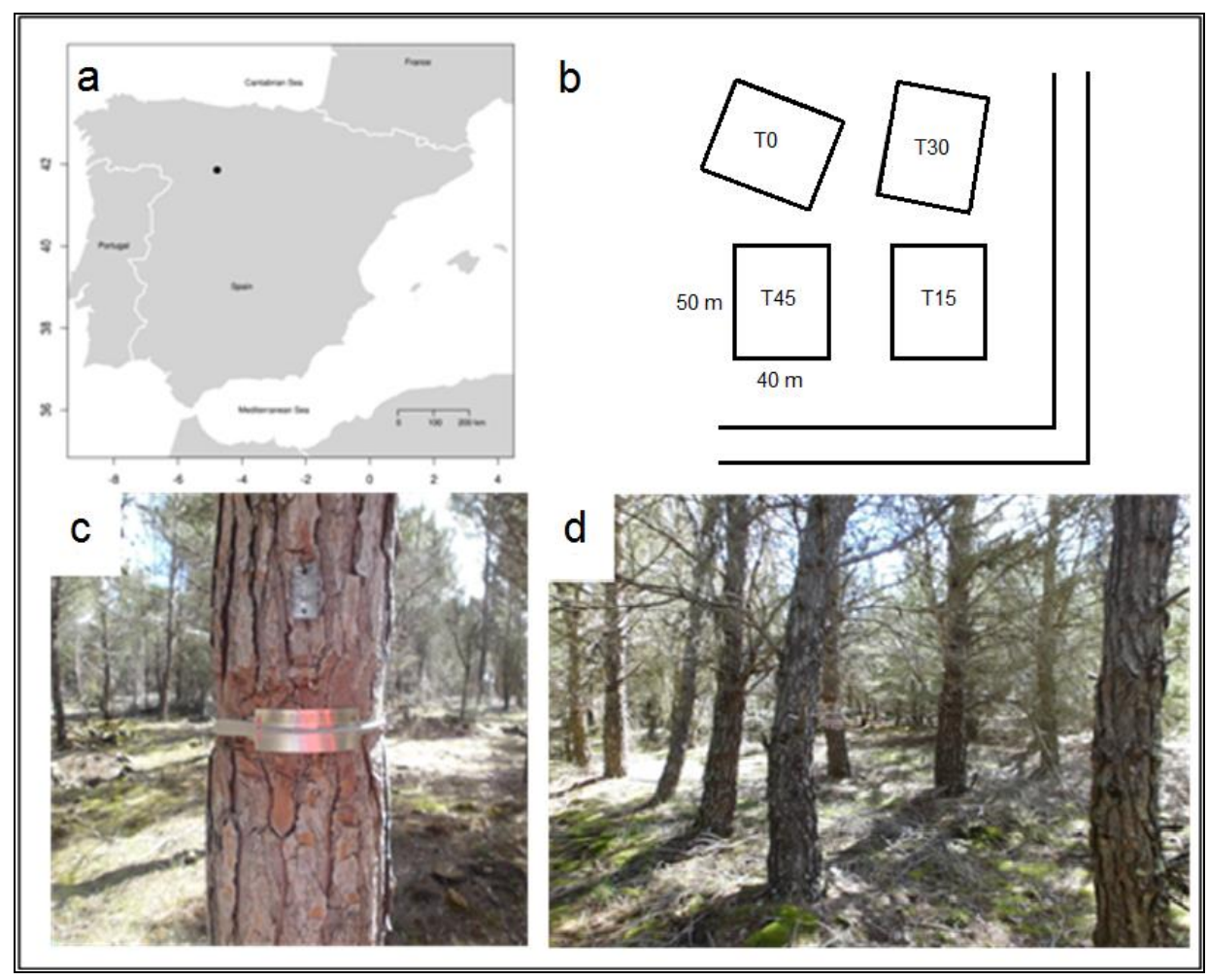

Fig. 1: (a) Study area of Pinus halepensis in Spain. (b) Large scale map of the thinning experiment. 
(c) Band dendrometer (Dendrometer Increment Sensor DB20 EMS Brno). (d) T0: unthinned stand.

\section{Thinning treatments}

Thinning treatments were conducted in autumn 2010 in three stands of similar basal area and stand structure (Table 1). The stand sizes were $40 \mathrm{~m} \times 50 \mathrm{~m}$. Three thinning intensities were considered: $15 \%$ reduction of the basal area (T15), 30\% reduction of the basal area (T30) and 45\% reduction of the basal area (T45), using an unthinned stand as control (T0) (Fig. 2). The reduction of the basal area was based on initial basal area of each stand.

Table 1 Stand parameters of the four plots. $B A=$ Basal area; $D B H=$ Diameter at breast height; $H_{0}$ = Dominant height (mean height of the hundred largest trees per hectare); LAI = Leaf area index (projected needle area per unit ground area).

\begin{tabular}{ccccccccc}
\hline Stand & $\begin{array}{c}\text { Thinning } \\
\text { intensity }\end{array}$ & $\mathrm{H}_{0}(\mathrm{~m})$ & $\begin{array}{c}\text { Initial } \\
\mathrm{BA} \\
\left(\mathrm{m}^{2} / \mathrm{ha}\right)\end{array}$ & $\begin{array}{c}\text { Final BA } \\
\left(\mathrm{m}^{2} / \mathrm{ha}\right)\end{array}$ & $\begin{array}{c}\text { Initial } \\
\text { Mean } \\
\mathrm{DBH}(\mathrm{cm})\end{array}$ & $\begin{array}{c}\text { Final } \\
\text { Mean } \\
\text { DBH }(\mathrm{cm})\end{array}$ & $\begin{array}{c}\text { Initial } \\
\text { LAI }\end{array}$ & $\begin{array}{c}\text { Final } \\
\text { LAI }\end{array}$ \\
\hline $\mathrm{T} 0$ & $0 \%$ & 10.6 & 22.6 & 22.6 & 18.6 & 18.6 & 1.90 & 1.90 \\
$\mathrm{~T} 15$ & $15 \%$ & 10.1 & 27.6 & 23.5 & 18.2 & 18.9 & 2.19 & 1.90 \\
$\mathrm{~T} 30$ & $30 \%$ & 9.4 & 20.0 & 14.0 & 17.1 & 18.5 & 1.97 & 1.45 \\
$\mathrm{~T} 45$ & $45 \%$ & 9.1 & 20.5 & 11.2 & 17.6 & 21.2 & 1.80 & 1.00 \\
\hline
\end{tabular}

The thinning treatments conducted on pine species in this area usually follow a $30 \%$ reduction of the total basal area, and the Marginal Thinning Intensity (MTI), defined as maximum intensity that can be maintained without loss of volume production (Kula, 1988), might be close to a $45 \%$ removal of the total basal area. 


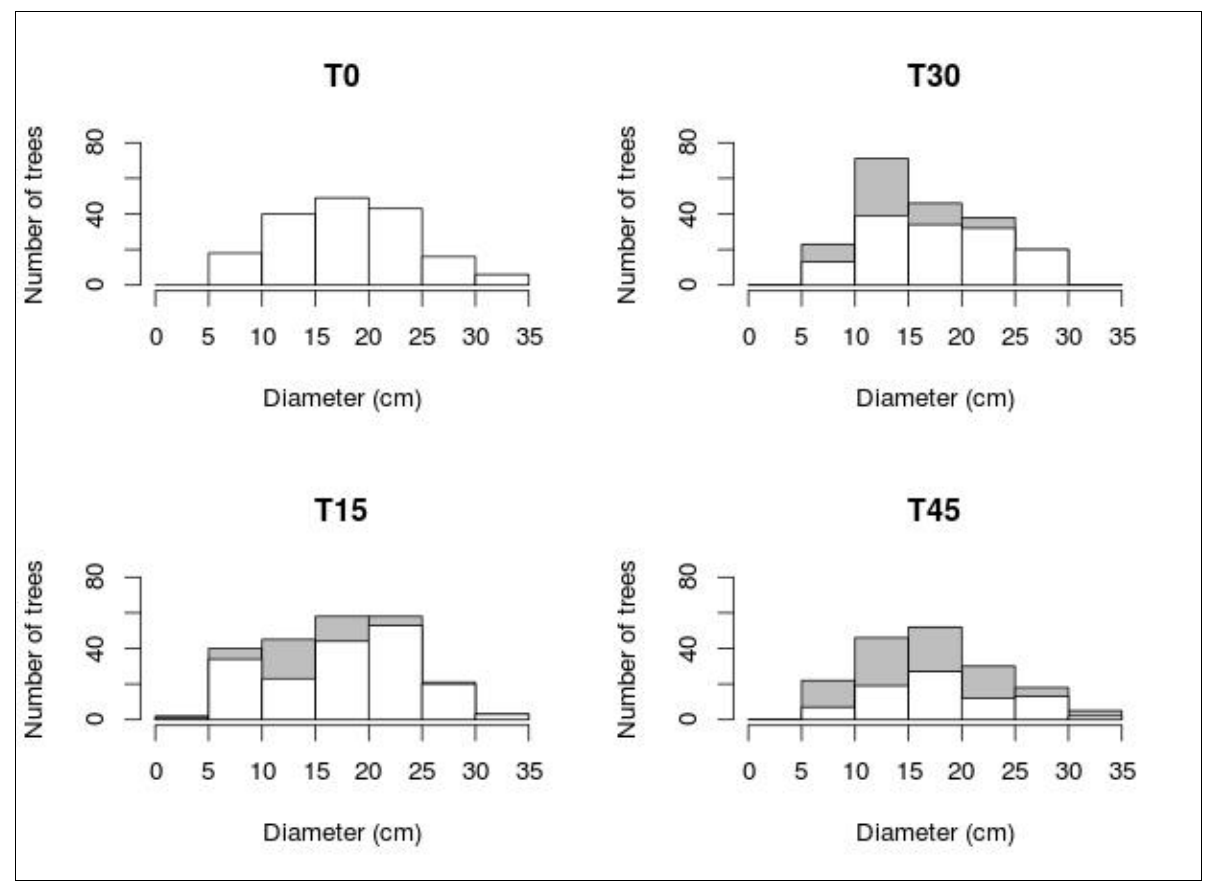

Fig. 2: Thinning treatments of Pinus halepensis at the four plots. Grey: extracted trees. T0: unthinned stand; T15: $15 \%$ reduction of the total basal area; T30: 30\% reduction of the total basal area; T45: $45 \%$ reduction of the total basal area.

\section{Dendrometer measurements}

To estimate the changes in stem increment, 48 stainless-steel band dendrometers (Dendrometer Increment Sensor DB20 EMS Brno) were mounted around the stem at $1.3 \mathrm{~m}$ height in 12 randomly chosen trees per treatment: 6 dominant trees (trees with crowns receiving full light from above and partly from the side) and 6 suppressed (trees with crowns receiving no direct light either from above or from the sides) in each plot. In most cases, the diameter of dominant trees ranged from 20 to $25 \mathrm{~cm}$ and suppressed trees from 10 to $15 \mathrm{~cm}$. However, some trees were chosen as dominant or suppressed being out of these ranges if their relative position in relation to its neighbours gave them the dominant or suppressed status.

Dead outermost tissue of the bark was smoothly and evenly removed with a rasp before attaching the dendrometer. Removing the bark allowed us to reduce swelling and shrinkage from the bark as a component of the increment dynamics. Dendrometer readings to the nearest $0.01 \mathrm{~mm}$ were performed biweekly over a two-year period. Readings were done in 
the morning to reduce diurnal bias because daytime transpiration causes stem shrinkage (Zweifel et al. 2001). Following Keeland and Sharitz (1993), measurements obtained in the first 3 months after installation were discarded for being within the adjustment period of the band dendrometers.

\section{Statistical analyses}

Daily climatic data were measured at the closest meteorological station (data provided by InfoRiego and the Spanish Meteorological Agency AEMET). Soil water availability to the trees, which can be characterized by relative extractable water (hereafter abbreviated as REW), was included in the analysis. REW is the daily available water standardized by maximum available water. Water stress is assumed to occur when REW drops below a threshold of 0.4 under which transpiration is gradually reduced due to stomatal closure (Granier et al. 1999). REW was calculated by the daily water balance model Biljou@ (https://appgeodb.nancy.inra.fr/biljou/) (Granier et al. 1999). This model requires daily potential evapotranspiration and rainfall as input climatic data. Evapotranspiration was calculated with the Penman potential evapotranspiration equation (Granier et al. 1999). Required site and stand parameters are maximum extractable soil water and leaf area index (LAI). Soil properties were measured at the site are considered homogeneous at the four plots (Table 2). LAI controls stand transpiration, forest floor evapotranspiration and rainfall interception (Granier et al. 1999). LAI was calculated acording with López-Serrano et al. (2000):

$L_{\mathrm{t}}=0.0536 * D^{2.05}$

where $L_{\mathrm{t}}$ is the leaf area of individual tree $(\mathrm{m} 2)$ and $D$ is the DBH $(\mathrm{cm} 2), R^{2}=85.53 \%$ (Table 1). The bioclimatic variables (temperature, precipitation, evapotranspiration and REW) were averaged (or accumulated in the case of precipitation) in 5, 15 and 30 days prior to prior to each diameter measurement in order to determine which climatic variables were the main constraints for growth and at which temporal scales they act. These weather intervals were selected under the assumption that growth responded to weather or climatic variables that prevailed just prior to each growth period. 
Table 2: Soil characteristics of the study area of Pinus halepensis included in the model Biljou@ (Granier et al., 1999).

\begin{tabular}{ccc}
\hline Variables & Horizon 1 & Horizon 2 \\
\hline Dept $(\mathrm{cm})$ & $0-30$ & $30-200$ \\
Water reserve (mm) & 36 & 48 \\
Roots (\%) & 75 & 25 \\
Stones (\%) & 1 & 80 \\
Humidity (pF 4.2) & 0.0158 & 0.0158 \\
Apparent density & 1.46 & 1.46 \\
\hline
\end{tabular}

In order to test similarity of growth rates prior to thinning among the four plots, increment cores were extracted from a total of 15 trees in the four plots. As preliminary trials, we fitted a linear model using past growth as response variable and a mixed model including a plot random effect. The relative goodness of fit of the models was assessed using the Akaike information criterion (AIC). Since AIC value (4399) did not change when the plot random effect was included, we concluded that the average growth was not different across the plots.

We fitted a linear mixed-effect model using the lme function with R-Package nlme (Laird and Ware, 1982). The model was fitted by maximizing the restricted log-likelihood:

$G r_{i j k}=\beta_{0}+\beta_{1} * \operatorname{Clim}_{i k}+\beta_{2 i m}+\beta_{3} * S_{i j}+\beta_{4} *\left(\operatorname{Clim}_{i k} * S_{i j}\right)+\beta_{5 i m} * S_{i j}+b_{i j}+\varepsilon_{i j k}$

$b_{i j} \sim N\left(0, \sigma^{2}\right.$ Tree $)$

$\varepsilon_{i j k} \sim N\left(0, \sigma^{2}\left|\operatorname{Clim}_{i k}\right|^{2 \delta}\right)$

where $G r$ is the radial growth, Clim are the mean (or accumulated) values of the bioclimatic variables (temperature, precipitation, evapotranspiration and relative extractable water), $i$ is the plot index, $j$ is the tree index, $k$ is the two-week period index, $m$ is the thinning intensity index such that: 
$m=1$ for the $15 \%$ thinning intensity

$m=2$ for the $30 \%$ thinning intensity

$m=3$ for the $45 \%$ thinning intensity

$S$ is an indicator variable for the status of the tree $(S=0$ for suppressed trees and $S=1$ for dominant trees), $b_{i j}$ is a tree random effect and the variance of the residual error terms $\varepsilon_{i j k}$ is modelled as $\sigma^{2}$, multiplied by the power of the absolute value of covariate Clim. The parameter $\delta$ is also estimated using a maximum likelihood estimator (see Zuur et al. 2009).

The period used for growth and climate analysis corresponded only with the main period of stem growth (Deslauriers et al. 2007). Based on our records, the period between 20 November 2011 and 15 April 2012 was excluded from the analysis. Statistical analyses were performed using $\mathrm{R}$ software (R Development Core Team 2011). Initial stand density was similar between sites. However, there were some differences due to microsite effect prevailing in Mediterranean environments. In order to probe similarity of growth rates prior to thinning among the four plots, past radial growth (40 years) was tested through increment cores extracted from 15 trees belonging to the four plots. We fitted a linear model using past growth as a response variable and a mixed model including the plot random effect. The relative goodness of fit of the models was assessed using the Akaike information criterion (AIC). Since AIC value (4399) did not change when the plot random effect was included, we can conclude that there are no significant differences on previous growth between plots.

Climate sensitivity is defined as the degree of growth response to climate variability. Because our growth data are intra-annual, coefficient of variation (hereafter abbreviated as $\mathrm{CV}$ ), which shows the extent of variability in relation to the mean, was calculated in order to assess the climate sensitivity of the radial increment series. CV was calculated for the radial growth during the 2 -week growth periods on each tree and analysed for trees within status, plots and years. 


\section{Results}

The results of the linear mixed-effect model applied for each variable (temperature, precipitation, evapotranspiration and REW) confirmed that REW was the main bioclimatic variable that influenced tree radial growth at the studied stands (Table 3).

Table 3: Comparison of the linear mixed-effect model for the different bioclimatic variables (mean or accumulated of the previous 5, 15 and 30 days). AIC = Akaike information criterion; $R M S E=$ Root Mean Square Error; ETP = Evapotranspiration; $T=$ Mean temperature; $P P=$ Accumulated precipitation; $R E W=$ Relative extractable water (daily available water standardized by maximum available water).

\begin{tabular}{cccc}
\hline Variable & $\begin{array}{c}\text { Delay } \\
\text { (days) }\end{array}$ & AIC & RMSE \\
\hline \multirow{2}{*}{ ETP } & 5 & 4565 & 0.016 \\
& 15 & 4539 & 0.015 \\
& 30 & 4463 & 0.014 \\
\hline \multirow{2}{*}{$\mathrm{T}$} & 5 & 4226 & 0.014 \\
& 15 & 4155 & 0.013 \\
& 30 & 4009 & 0.012 \\
\hline \multirow{2}{*}{ PP } & 5 & 4165 & 0.013 \\
& 15 & 4196 & 0.014 \\
& 30 & 4165 & 0.013 \\
\hline \multirow{2}{*}{ REW } & 5 & 3745 & 0.011 \\
& 15 & 3734 & 0.011 \\
& 30 & 3978 & 0.011 \\
\hline
\end{tabular}

Mean REW of the previous 15 days showed the lowest AIC values. The comparison between mean REW of the previous 15 days and radial increment of the four plots can be observed in Fig. 3. Growth increased with thinning intensity. 


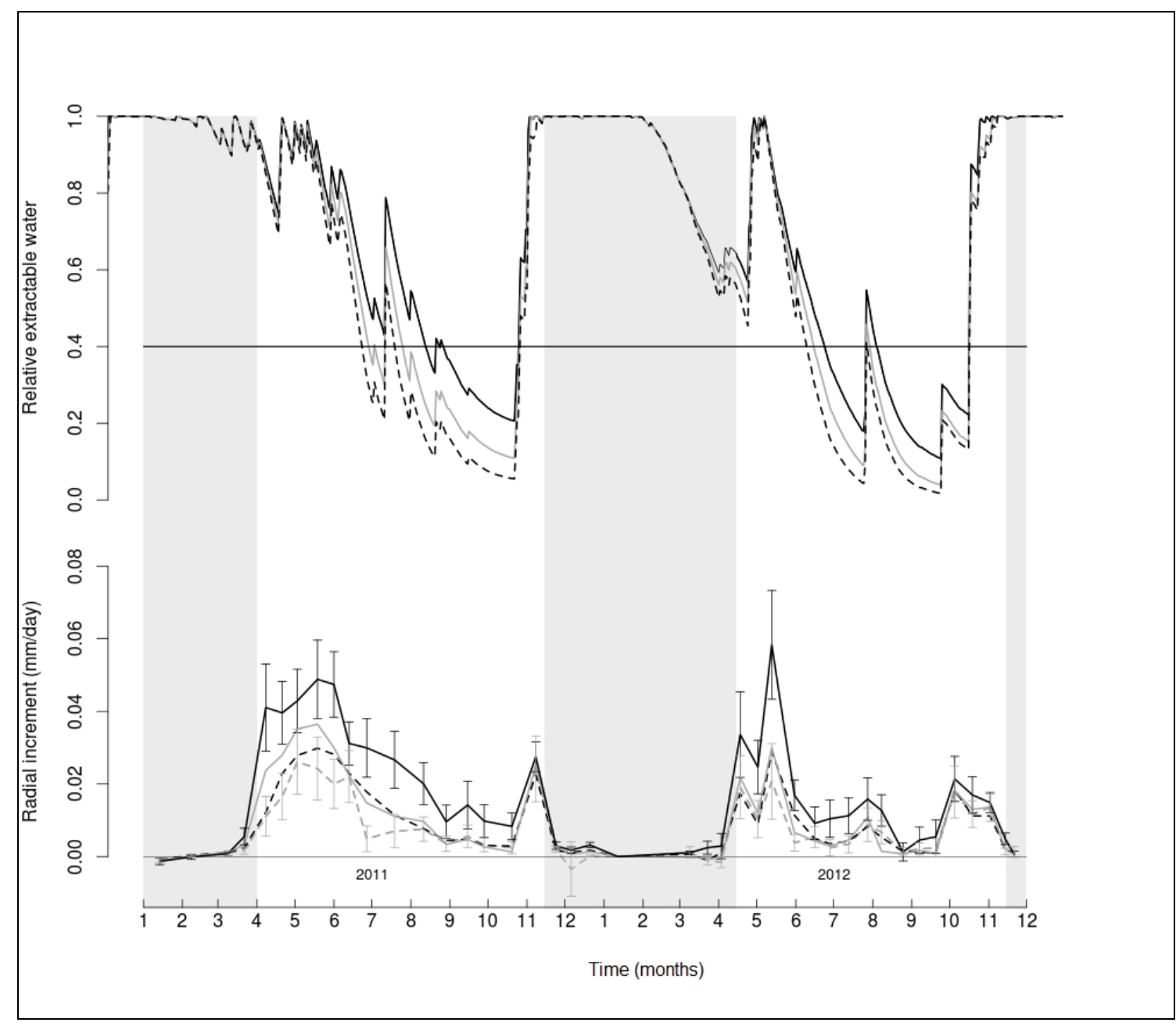

Fig. 3: Relative extractable water (daily available water standardized by maximum available water) and radial increment of Pinus halepensis at the four plots. T45: black solid line, T30: grey solid line, T15: black dashed line. T0: black dashed line for REW and grey dashed line for radial increment. Water stress is assumed to occur when REW drops below a threshold of 0.4 (Granier et al. 1999). Grey areas show periods not considered for the analysis.

We fitted the model with mean REW of the previous 15 days (Table 4) as climatic variable. Results showed that dominant trees and trees in T30 and T45 had significantly higher growth rates. 
Table 4: Results of the linear mixed-effect model for REW15. Relative extractable water (REW) is the daily available water standardized by maximum available water. T0: unthinned stand; T15: 15\% reduction of the total basal area; T30: 30\% reduction of the total basal area; T45: 45\% reduction of the total basal area.

\begin{tabular}{cccc}
\hline Parameter & Value & Std. Error & P-value \\
\hline Intercept & -0.0004 & 0.0017 & 0.834 \\
Dominant & 0.0049 & 0.0025 & 0.055 \\
REW & 0.0081 & 0.0018 & $<0.0001$ \\
T15 & -0.0014 & 0.0025 & 0.587 \\
T30 & -0.0006 & 0.0026 & 0.793 \\
T45 & -0.0032 & 0.0026 & 0.223 \\
Dominant * REW & 0.0233 & 0.0018 & $<0.0001$ \\
T15 * REW & 0.0055 & 0.0023 & 0.017 \\
T30 * REW & 0.0093 & 0.0024 & $<0.0001$ \\
T45 * REW & 0.0248 & 0.0026 & $<0.0001$ \\
Dominant * T15 & 0.0005 & 0.0036 & 0.896 \\
Dominant * T30 & -0.0042 & 0.0036 & 0.253 \\
Dominant * T45 & -0.0014 & 0.0036 & 0.708 \\
\hline$\sigma^{2}$ Tree & 0.0042 & & \\
\hline & & & \\
\hline & & & \\
\hline
\end{tabular}

The comparison between real growth and predicted values of the model for T0 and T45 are shown in Fig. 4. Model predictions are more accurate for dominant than suppressed trees and for T45 than T0. 


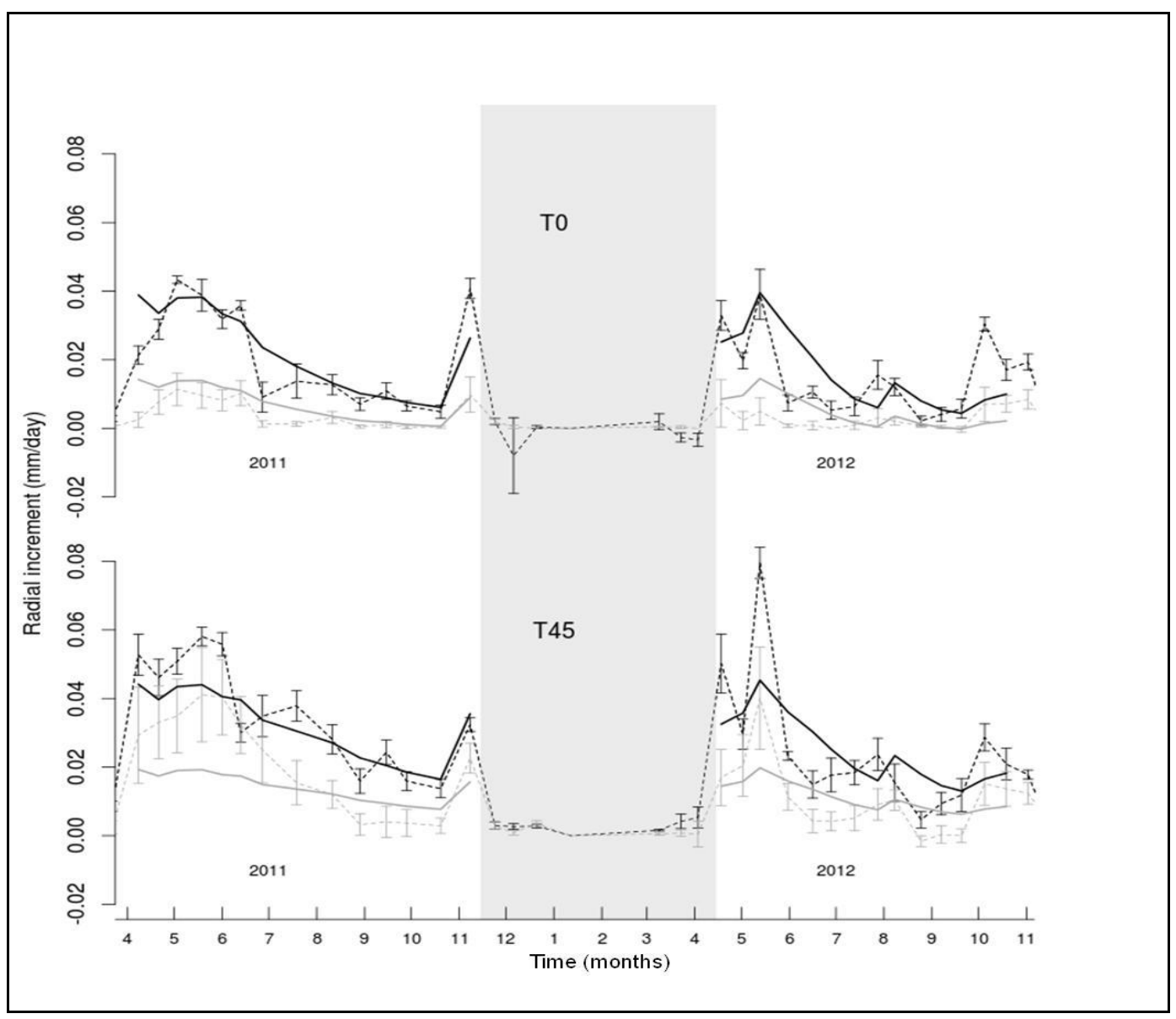

Fig. 4: Real growth of Pinus halepensis (dashed lines) and growth predictions from the model (solid line). Black: dominant trees (trees with crowns receiving full light from above and partly from the side); grey: suppressed trees (trees with crowns receiving no direct light either from above or from the sides). T0: unthinned stand. T45: 45\% reduction of the total basal area. Grey areas show periods not considered for the analysis.

Growth patterns of the four stands are described in Fig. 5. The growth dynamics of $P$. halepensis showed a bimodal growth pattern, with two major growth phases in spring and autumn and low rates in late summer and beginning of autumn. The spring maximum increment rate was higher than the autumn maximum increment rate, except for T0 in 2011. 


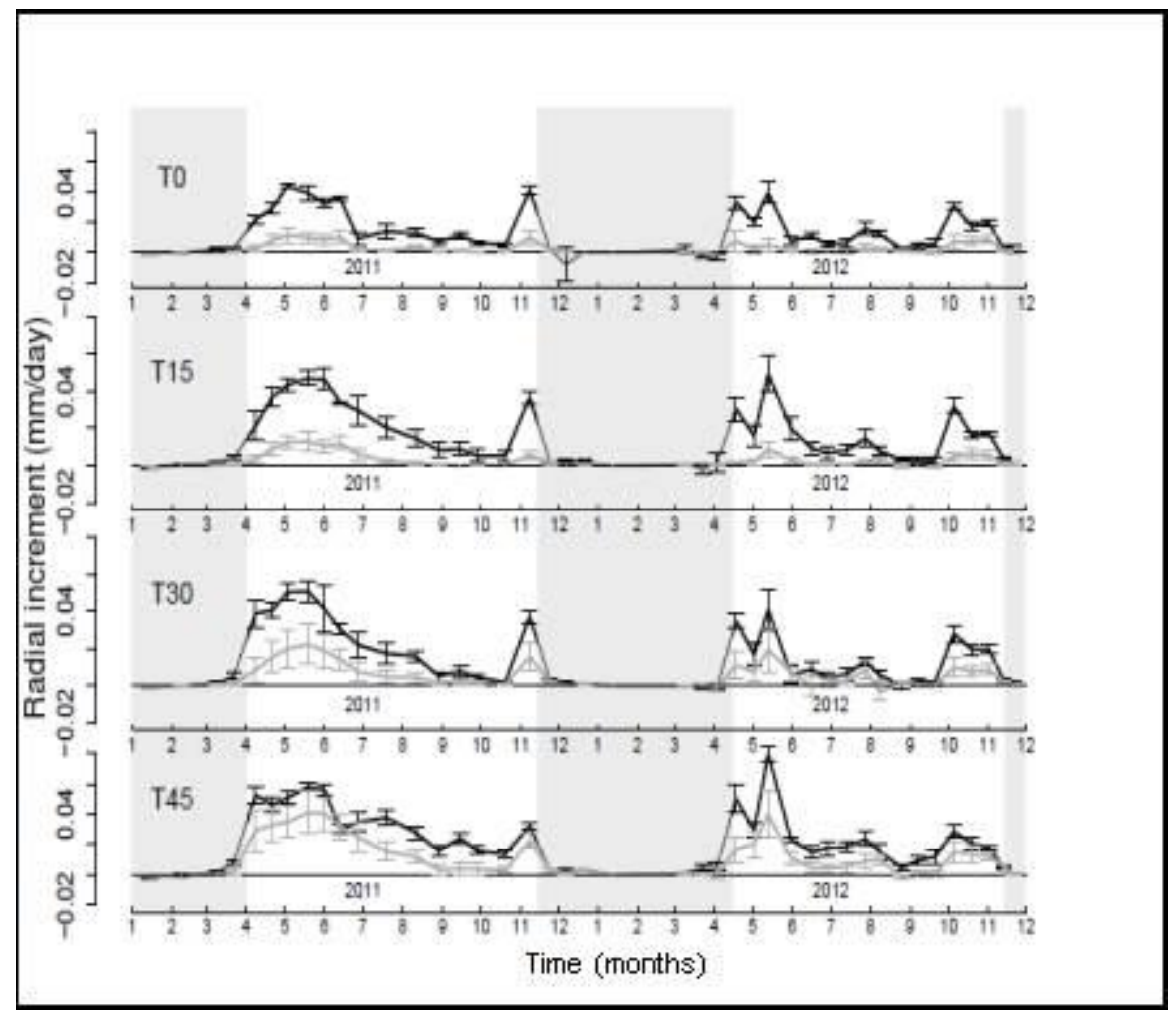

Fig. 5: Growth dynamics of Pinus halepensis at the study site. Black line: dominant trees (trees with crowns receiving full light from above and partly from the side); grey line: suppressed trees (trees with crowns receiving no direct light either from above or from the sides). Grey areas show periods not considered for the analysis.

The analysis of the variance of the growth data (Fig. 6) showed that suppressed trees had higher $\mathrm{CV}$ values than dominant trees. T45 showed the lowest $\mathrm{CV}$ values in both crown classes during the two years of study. 


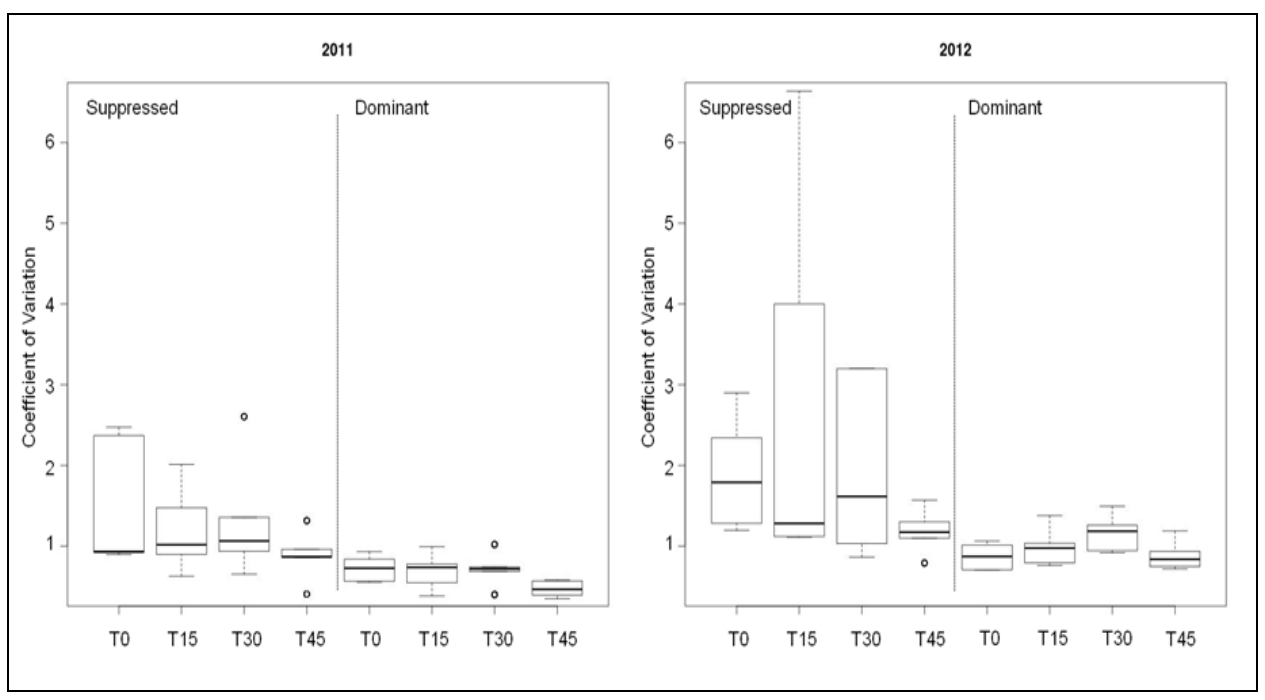

Fig. 6: Coefficient of variation of the growth data of Pinus halepensis at the four plots: unthinned stand (T0); $15 \%$ reduction of the total basal area (T15); 30\% reduction of the total basal area (T30) and $45 \%$ reduction of the total basal area (T45). Dominant trees: trees with crowns receiving full light from above and partly from the side. Suppressed trees: trees with crowns receiving no direct light either from above or from the sides.

\section{Discussion}

Dendrometers have been criticized when used to record cambial activity with a high temporal resolution because of the reversible stem shrinking and swelling (de Luis et al. 2007). These criticisms are, to some extent, justified when dendrometers are used to identify cambial growth onset and ending or differentiate growth from stem water content variation in slow-growing species (Deslauriers et al. 2007). However, several studies have been published in recent years describing stem growth phenology and/or assessing growth-climate relationships (Bouriaud et al. 2005; de Luis et al. 2007; Gea-Izquierdo et al. 2009; Linares et al. 2009; Camarero et al. 2010; Gutierrez et al. 2011). In our study, removing the bark and the fixing interval of the day during that stem radius variation was measured allowed us to improve precision by eliminating effects of bark irregularities and subtle sloughing and to reduce swelling and shrinkage as a component of the increment dynamics (Zweifel et al. 2001).

REW is the main bioclimatic variable which influences tree radial growth at the studied 
stands. These results add information to previous inter-annual studies on the same stands (Olivar et al. 2012) that defined monthly rainfall as the main climatic driver of tree growth. The utilisation of soil moisture rather than rainfall is less susceptible to confounding between the effects of water and temperature in the growth response function. Furthermore, soil moisture has more biological meaning than precipitation because it better reflects water availability for trees. These points are particularly relevant for studies performed in Mediterranean regions (Rathgeber et al. 2005).

In the Mediterranean area with a continuous water deficit, at least for P. halepensis, wood formation reflects environment conditions for most of the year, and a precipitation event is generally followed by an increase in growth within a week after the event (Attolini et al. 1990). Water availability is expected to be the major limiting factor for growth under a Mediterranean climate and its influence decreases with altitude in the Mediterranean region, with temperature showing the opposite trend (Cherubini et al. 2003). There is a general idea that radial growth is primarily dependent on the short-term water availability, which affects the actual tree water status and xylogenesis (Eilmann et al. 2009). In the studied stands, the influence of REW on dominant trees was significantly higher than on suppressed trees. In drought stressed environments, suppressed trees usually have shallower and less developed root systems than dominant trees, and less moisture is available to them (Van Lear and Kapeluck 1995). Therefore, the amount of available water for suppressed trees is limited to the short term water reserves concentrated in surface soil layers; while dominant trees, with more developed root systems can access to deeper soil water reserves accumulated in longer terms (Camarero et al. 2010), inducing higher vulnerability of suppressed trees to water stress.

The growth dynamics of $P$. halepensis had two major growth phases during the growing season, one in spring and another in autumn, interrupted by a period with low or no cambial activity during late summer as a result of drought and high temperatures (Cherubini et al. 2003). This pattern of xylem production is responsible for the frequent formation of intraannual density fluctuations observed in this species (Olivar et al. 2012). Stem growth started at middle March in 2001 and April in 2012, when temperatures were high enough for vegetative growth, and stopped growing at the end of November in both years, when 
temperatures were too low. The radial growth pattern of $P$. halepensis was asymmetrical with most of the annual growth occurring in spring. The maximum growth rate in spring was the highest of the year except for T0 in 2011, where the autumn maximum growth rate was higher. Growth patterns of $P$. halepensis showed high-plasticity in response to climatic conditions during the growing season, which may be an advantage in areas with a Mediterranean climate where the annual rainfall pattern is variable (Gutiérrez et al. 2011). P. halepensis has been characterized as a sensitive Mediterranean species based on the strong response of growth dynamics to changes in climatic conditions (Lev-Yadun 2000). It has also been suggested that the cambium is able to remain active throughout the whole year when climate conditions are favourable (Liphschitz et al. 1984).

Growth rates prior to thinning probed to be not significantly different among the experimental units, suggesting that the thinning intensities were sufficient to account for residual stand density. Therefore, we can conclude that T30 and T45 thinning treatments were able to induce a growth release on both crown classes that did not occur under less intense thinning treatments. Thinning is less effective at dry sites if it is not intense enough, because inter-tree competition for water is stronger and drier sites cannot support stands of sufficiently high density to warrant thinning (Cotillas et al. 2009; Linares et al. 2009; Moreno and Cubera 2008). Thus, a still high competition level that is not sufficiently reduced by thinning, coupled with the more limiting climatic conditions, should have obscured the advantages of thinning on less intense thinning treatments (Misson et al. 2003).

Growth variability was higher in suppressed than in dominant trees. T45 showed the lowest $\mathrm{CV}$ values in both crown classes, which means higher homogeneity of the growth data. Tree growth responses to climate are highly context-dependent (Carnwath et al. 2012). However, these results are in agreement with the idea that in semi-arid environments, suppressed trees usually have more limited access to soil water reserves than dominant trees, due to their shallower and less developed root systems, especially in high density stands. Therefore, their growth rates fluctuate depending on short term water reserves concentrated in surface soil layers, while dominant trees with more developed root systems and suppressed trees released from competition show more homogeneous growth rates. 
The reduction of stand density through thinning has been suggested to improve the resistance of individual trees to drought stress and the extent of this differential response changes within the same species along climatic gradients (Misson et al. 2003; Moreno and Cubera 2008; Gea-Izquierdo et al. 2009). However, this conclusion should not be extrapolated to generalise that open stands are always desirable (Gea-Izquierdo et al. 2009). Forest managers should retain adequate stand density to mitigate the effect of climatic extremes taking other ecosystem parameters such as regeneration or soil protection into account. Less dense and more diverse stands could be promoted by mixing species with different drought resistance to avoid or limit further growth declines in plantations.

\section{Acknowledgements}

The authors wish to thank Cristina Prieto, Irene Ruano and Lucía Risio for their help on the installation of the dendrometers, InfoRiego and the Spanish Meteorological Agency for providing the meteorological data and Jorge Leporati for his help on data analysis.

\section{Funding}

Funding was provided by the Spanish Research National Projects AGL-2007-65795-C0201 and AGL2011-29701-C02-02.

\section{References}

Adams, H.D., Kolb, T.E., 2004. Drought responses of conifers in ecotone forests of northern Arizona: tree ring growth and leaf d13C. Oecologia 140: 217-225.

Attolini, M.R., Calvani, F., Galli, M., Nanni, T., Ruggiero, L., Schaer, E., Zuanni, F., 1990. The relationship between climatic variables and wood structure in Pinus halepensis Mill. Theor Appl Climatol 41: 121-127.

Camarero, J.J., Olano, J.M., Parras, A., 2010. Plastic bimodal xylogenesis in conifers from continental Mediterranean climates. New Phytol 185: 471-480.

Carnwath, G.C., Peterson, D.W., Nelson, C.R., 2012. Effect of crown class and habitat type on climate-growth relationships of ponderosa pine and Douglas-fir. For Ecol Manage 285: 
44-52.

Cherubini, P., Gartner, B.L., Tognetti, R., Bräker, O.U., Schoch, W., Innes, J.L., 2003. Identification, measurement and interpretation of tree rings in woody species from mediterranean climates. Biol Rev Camb Philos Soc 78: 119-148.

Cotillas, M., Sabaté, S., Gràcia, C., Espelta, J.M., 2009. Growth response of mixed Mediterranean oak coppices to rainfall reduction: Could selective thinning have any influence on it? For Ecol Manage 258: 1677-1683.

De Luis, M, Gričar, J., Čufar, K., Raventós, J., 2007. Seasonal dynamics of wood formation in Pinus halepensis from dry and semi-arid ecosystems in Spain. IAWA J 28:389404.

Gea-Izquierdo, G., Martín-Benito, D., Cherubini, P., Cañellas, I., 2009. Climate-growth variability in Quercus ilex L. west Iberian open woodlands of different stand density. Ann For Sci 66: 802.

Granier, A., Bréda, N., Biron, P., Viville, S., 1999. A lumped water balance model to evaluate duration and intensity of drought constraints in forest stands. Ecol Model 116: 269-283.

Gutiérrez, E., Campelo, F., Camarero, J.J., Ribas, M., Muntán, E., Nabais, C., Freitas, H., 2011. Climate controls act at different scales on the seasonal pattern of Quercus ilex L. stem radial increments in NE Spain. Trees. doi:10.1007/s00468-011-0540-3.

Keeland, B.D., Sharitz, R.R., 1993. Accuracy of tree growth measurements using dendrometer bands. Can J Forest Res 23: 2454-2457.

Kula, E., 1988. The economics of forestry: modern theory and practice. Timber Press, Portland, USA.

Laird, N.M., Ware, J.H., 1982. Random effects models for longitudinal data. Biometrics 38: 963-974.

Lev-Yadun, S., 2000. Wood structure and the ecology of annual growth ring formation in 
Pinus halepensis and P. brutia. Ecology, biogeography and management of Pinus halepensis and P. brutia. In: Néeman, G., Trabaud L., Forest ecosystems in the Mediterranean Basin, 67-78.

Linares, J.C., Camarero, J.J., Carreira, J.A., 2009. Plastic responses of Abies pinsapo xylogenesis to drought and competition. Tree Physiol 29: 1525-1536.

Liphschitz, N., Lev-Yadun, S., Rosen, E., Waisel, Y., 1984. The annual rhythm of activity of the lateral meristems (cambium and phellogen) in Pinus halepensis Mill. and Pinus pinea L. IAWA Bull. n.s. 5: 263-274.

López-Serrano, F. R., Landete-Castillejos, T., Martínez-Millán, J., del Cerro-Barja, A., 2000. LAI estimation of natural pine forest using a non-standard sampling technique. Agr. Forest Meteorol. 101: 95-111.

Martín-Benito, D., del Río, M., Heinrich, H., Helle, G., Cañellas, I., 2010. Response of climate-growth relationships and water use efficiency to thinning in a Pinus nigra afforestation. For Ecol Manage 259: 967-975.

Misson, L., Nicault, A., Guiot, J., 2003. Effects of different thinning intensities on drought response in Norway spruce (Picea abies (L.) Karst.). For Ecol Manage 183: 47-60.

Mitrakos, K.A., 1980. A theory for Mediterranean plant life. Acta Oecol 1: 245-252.

Moreno, G., Cubera, E., 2008. Impact of stand density on water status and leaf gas exchange in Quercus ilex. For Ecol Manage 254: 74-84.

Néeman, G., Trabaud, L., 2000. Ecology, biogeography and management of Pinus halepensis and Pinus brutia forest ecosystems in the Mediterranean Basin. Backhuys Publication, Leiden.

Olivar, J., Bogino, S., Spiecker, H., Bravo, F., 2012. Climate impact on growth dynamic and intra-annual density fluctuations in Aleppo pine (Pinus halepensis) trees of different crown classes. Dendrochronologia 30, Issue 1: 35-47.

Orwig, D.A., Abrams, M.D., 1997. Variation in radial growth responses to drought among 
species, site, and canopy strata. Trees 11: 474-484.

Parry, M.L., Canziani, O.G., Palutikof, J.P., van der Linden, P.J., Hanson, C.E., 2007. Climate Change 2007: Impacts, Adaptation and Vulnerability. Contribution of Working Group II to the Fourth Assessment Report of the Intergovernmental Panel on Climate Change. Cambridge University Press, Cambridge.

Pasho, E., Camarero, J.J., Vicente-Serrano, S.M., 2012. Climatic impacts and drought control of radial growth and seasonal wood formation in Pinus halepensis. Trees. doi:10.1007/s00468-012-0756-X.

Peet, R.K., Christensen, N.L., 1987. Competition and tree death. BioScience 37: 586-594.

R Development Core Team, 2011. R: A language and environment for statistical computing. R Foundation for Statistical Computing, Vienna, Austria. ISBN 3-900051-07-0, URL. http://www.R-project.org.

Rathgeber, C., Misson, L., Nicault, A., Guiot, J., 2005. Bioclimatic model of tree radial growth: application to French Mediterranean Aleppo pine forests. Trees 19: 162-176.

Specht, R.L., 1981. Primary production in Mediterranean climate ecosystems regenerating after fire. In: Di Castri, F., Goodall, D.W., Specht, R.L. (Eds.), Mediterranean-type Shrublands. Elsevier, Amsterdam.

Van Lear, D.H., Kapeluck, P.R., 1995. Above- and below-stump biomass and nutrient content of a mature loblolly pine plantation. Can J For Res 25: 361-367.

Zuur. A., Ieno, E.N., Walker, N., Saveliev, A.A., Smith, G.M., 2009. Mixed Effects Models and Extensions in Ecology with R. Springer, New York.

Zweifel, R., Item, H., Häsler, R., 2001. Link between diurnal stem radius changes and tree water relations. Tree Physiol 21: 869-877. 
Olivar (2013)

160 


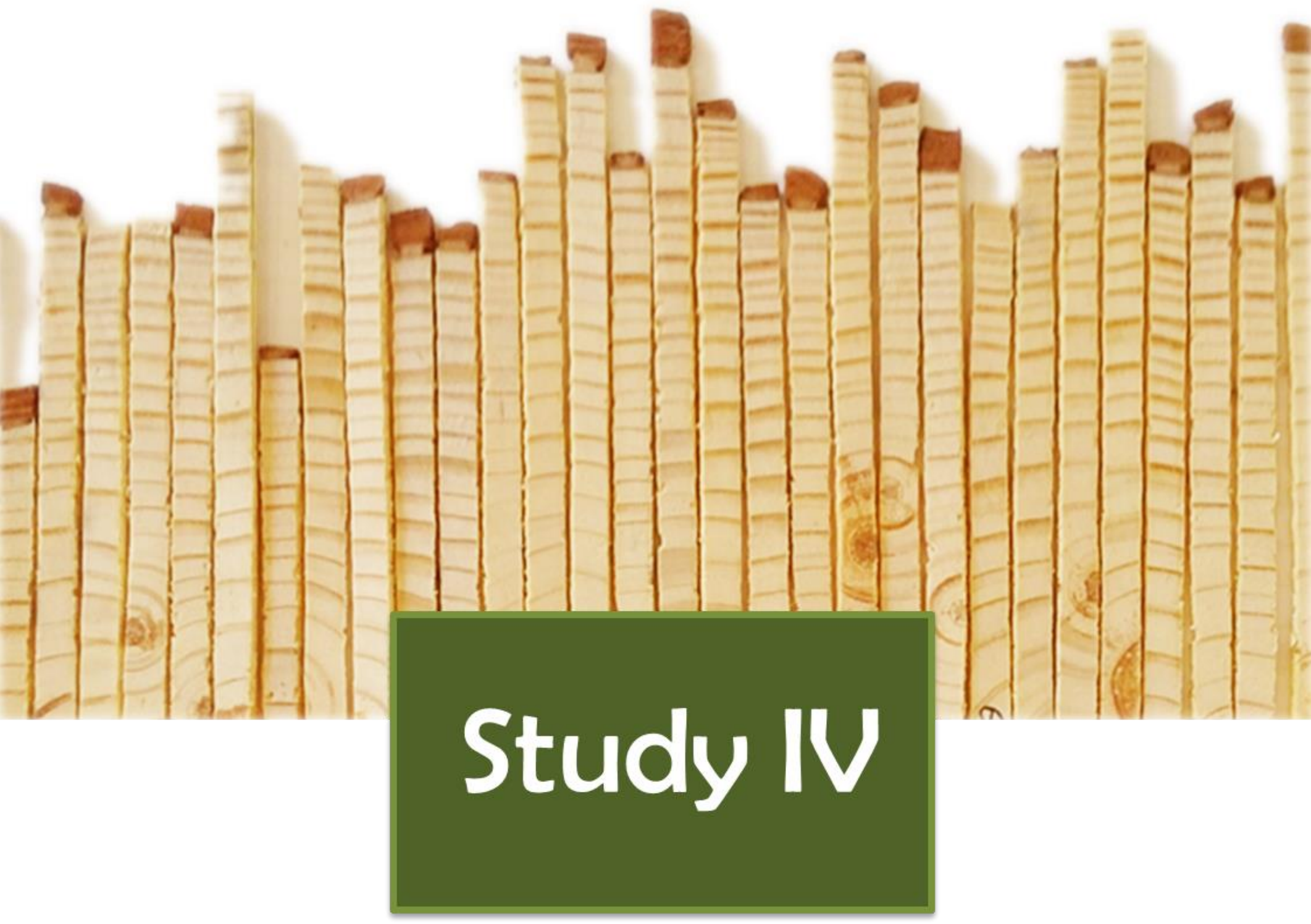

Climate impact on wood density in Pinus halepensis, Pinus pinaster and Pinus sylvestris

*Climate impact on wood density in Pinus halepensis, Pinus pinaster and Pinus sylvestris. 2013. Manuscript. 
Olivar (2013) 


\title{
Climate impact on wood density in Pinus halepensis, Pinus pinaster and Pinus sylvestris
}

\author{
Jorge Olivar ${ }^{1,2}$, Cyrille Rathgeber ${ }^{3}$, Felipe Bravo ${ }^{1,2}$ \\ ${ }^{1}$ Sustainable Forest Management Research Institute Universidad de Valladolid \& INIA. Avda. de Madrid 44. \\ 34071, Palencia, Spain \\ ${ }^{2}$ Departamento de Producción Vegetal y Recursos Forestales, Universidad de Valladolid, Avda. de Madrid \\ 44. 34004 Palencia, Spain \\ ${ }^{3}$ INRA, UMR 1092 LERFOB, F-54280 Champenoux, France
}

\begin{abstract}
During the second half of the $20^{\text {th }}$ century the Mediterranean area has experienced an increase in the mean annual temperature, a decrease in the mean annual precipitation, and an increase in the frequency of severe drought periods. As a consequence, pine species suffered a swift in the climate-growth relationships and increased its climate sensitivity. Understanding growth-climate relationships of pine species growing under Mediterranean climate is a key issue nowadays. However, wood features such as wood density are also affected by recent climatic changes producing an effect on wood structure and quality. In order to to identify the main climatic drivers of the radial growth and wood density patterns for Pinus halepensis, $P$. pinaster and P. sylvestris and to establish the relationships between tree-ring width and wood density in the three species, three sampling sites were selected throughout their natural distribution area in Spain. The results showed that precipitation influenced tree radial growth and wood density of the three species at different times of the growth period. Mean and maximum density followed different patterns on the three species, decreasing along time in $P$. pinaster and increasing in $P$. halepensis and $P$. sylvestris. Climatic conditions increasing radial growth reduced mean density and increased maximum density in P. halepensis. Pinus sylvestris showed a positive correlation between maximum latewood density and summer temperature, while $P$. halepensis and $P$. pinaster showed negative correlations. Despite the increasing climate sensitivity of pine species during the most recent years, the trend in growth and mean density does not change in a 5 years
\end{abstract}


interval. However, these inter-annual variability could have an effect on wood properties producing a loss of wood quality.

\section{Key words}

Aleppo pine, maritime pine, scots pine, mean wood density, maximum wood density.

\section{Introduction}

Global climate simulation studies predict that trees in Europe and especially in the Mediterranean region, which has been defined as a major climate change hotspot, are likely to experience more severe droughts and higher summer temperatures in the future (Parry et al., 2007). These changes could affect not only tree growth, but also tree-ring structure. Wood density is especially important as it is correlated with various physical, chemical, and anatomical features of the wood and thus yields basic information concerning problems of wood technology, forestry and climatology (Schweingruber et al., 1978; Fritts, 2001). Treerings are regularly composed of earlywood, in which tracheids have relatively large diameters and thin cell walls and latewood, with small tracheids having thick cell walls. Severe conditions during the growing season, such as water stress, may generate the production of latewoodlike cells within earlywood or earlywood-like cells within latewood (Schweingruber, 1978; Fritts, 2001) varying wood density patterns.

Dendroclimatic studies have shown that wood density is highly sensitive to climate variations at the inter-annual time scale (Parker and Henoch, 1971; Schweingruber et al., 1978; Conkey 1979; Briffa et al., 2001; Roderick and Berry, 2001; Bouriaud et al., 2005). Relationships between climate and wood anatomy or ring development have been also studied at intra-annual time scales in various tree species including conifers like norway spruce (Picea abies) (Horacek et al., 1999; Mäkinen et al., 2003; Bouriaud et al., 2005), silver fir (Abies alba), scots pine (Pinus sylvestris) and mountain pine (Pinus uncinata) (Büntgen et al., 2010), and broad leaved species like black locust (Robinia pseudacacia) (Schmitt et al., 2000) and beech (Fagus sylvatica) (Sass and Eckstein, 1995; Schmitt et al., 2000; van der Maaten et al., 2012), but little is known about intra-annual density-climate relationships in the Mediterranean, where the cambial activity can vary from year to year 
presenting continuous radial growth or one or two growth interruptions in line with the variability of climatic conditions (de Luis et al., 2007).

Previous studies in Spain concluded that the growth of $P$. halepensis and $P$. pinaster was influenced by wet periods during winter previous to the growth season and spring, while the growth of $P$. sylvestris was mostly influenced by summer precipitation (Bogino and Bravo, 2008; Bogino et al., 2009; Olivar et al., 2012). However, there were no previous studies on the impact of climate on wood density in these species. We hypothesize that: i) precipitation is the main climatic driver of the radial growth and wood density patterns for $P$. halepensis, $P$. pinaster and P. sylvestris; and ii) tree-ring width and mean density will be inversely correlated. The results will be valuable for increasing the understanding on the effects of changing environmental conditions on wood formation

\section{Materials and Methods}

The sampling sites were selected throughout the natural distribution area of Pinus halepensis, $P$. pinaster and P. sylvestris in Spain (Fig. 1). On each sampling site, 15 dominant trees were selected. Two cores were extracted at $1.30 \mathrm{~m}$ above ground from each selected tree. The samples were processed following standard techniques (Stokes and Smiley, 1968), conditioned to a $12 \%$ water content and resawn in the transverse plane to a thickness of $2 \mathrm{~mm}$. X-Ray negative photographs of the samples were obtained and the resulting X-ray picture was digitized and processed with CERD software (Mothe et al., 1998). The wood density profiles obtained are for each ring and are based on 100 measured positions. Wood density profiles were produced by averaging the values (XRD, kg/m3) obtained from these segments (Bouriaud et al., 2005; Rathgeber et al., 2006). 


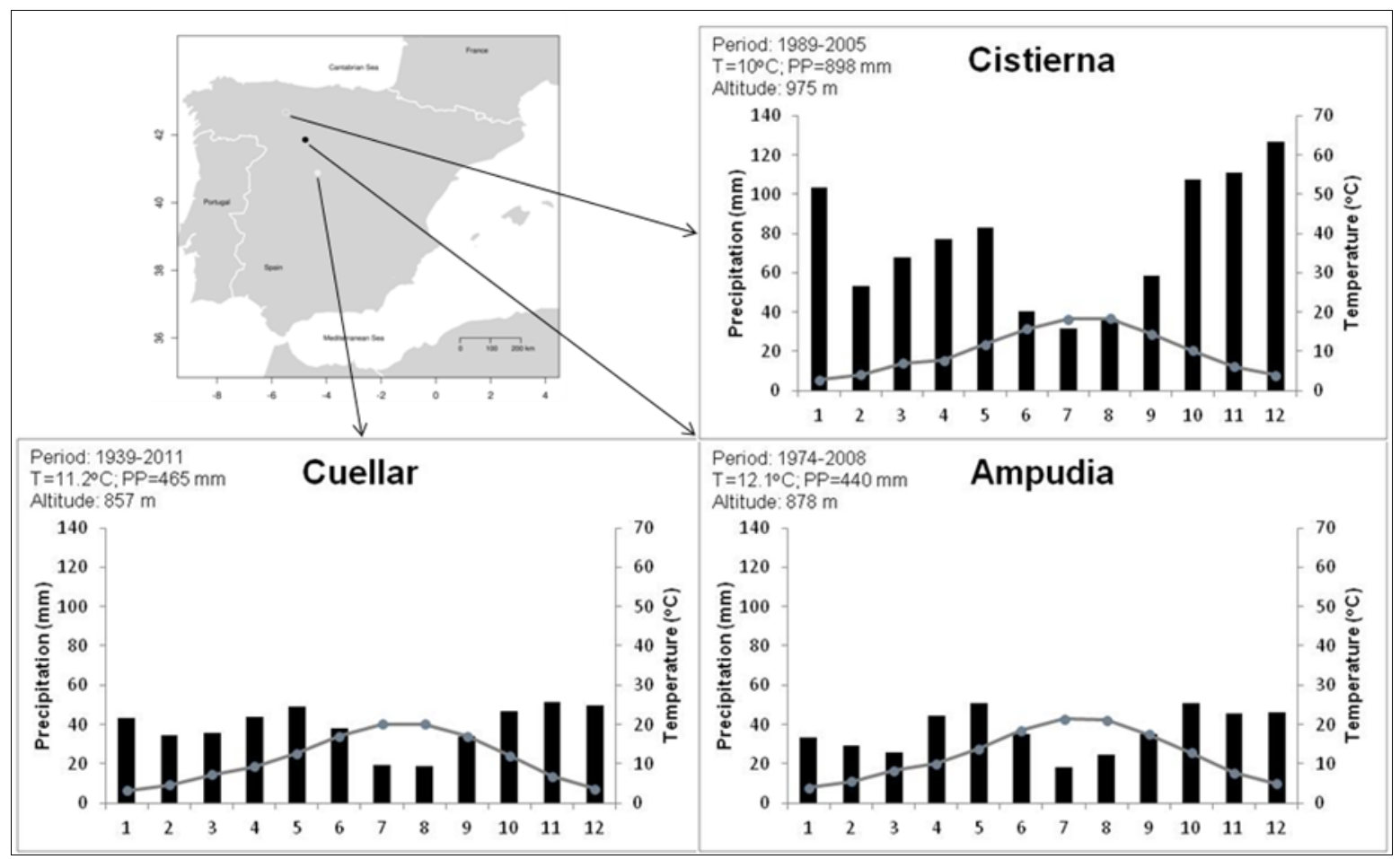

Fig. 1: Location of the three study sites in Spain. Black: Ampudia (P. halepensis); grey: Cuellar (P. pinaster); white: Cistierna (P. sylvestris).

Mean monthly temperature and monthly precipitation recorded at the closest meteorological stations (Agencia Estatal de Meteorología, Spain) were grouped in climatic seasons (winter previous to the growing season, spring, summer and autumn) and correlated with tree-ring width, earlywood width, latewood width, mean density, maximum density, earlywood density and latewood density.

To remove non-climatic age trends from the raw measurements, tree-ring width series were detrended (standardized) on a modified negative exponential curve using the package dplR (Bunn, 2008) in program R. Standardization removes geometrical and ecological trends while preserving inter-annual high-frequency variations that are presumably related to climate. The long-term trend was removed from each time series of ring width measurements by fitting and calculating an index defined as actual ring-width for each year divided by the curve-fit value. 


\section{Results}

The relationships between tree- ring width, wood density and climate was analysed for the three species.

Tree-ring width of $P$. halepensis was positively correlated to precipitation during previous winter and spring ( $p$-values>0.005) and spring temperature ( $p$-value>0.05). Tree-ring width of $P$. sylvestris was positively correlated to summer precipitation ( $p$-value >0.05) $P$. pinaster showed no significant correlations between tree-ring width and climatic variables (Fig. 2).

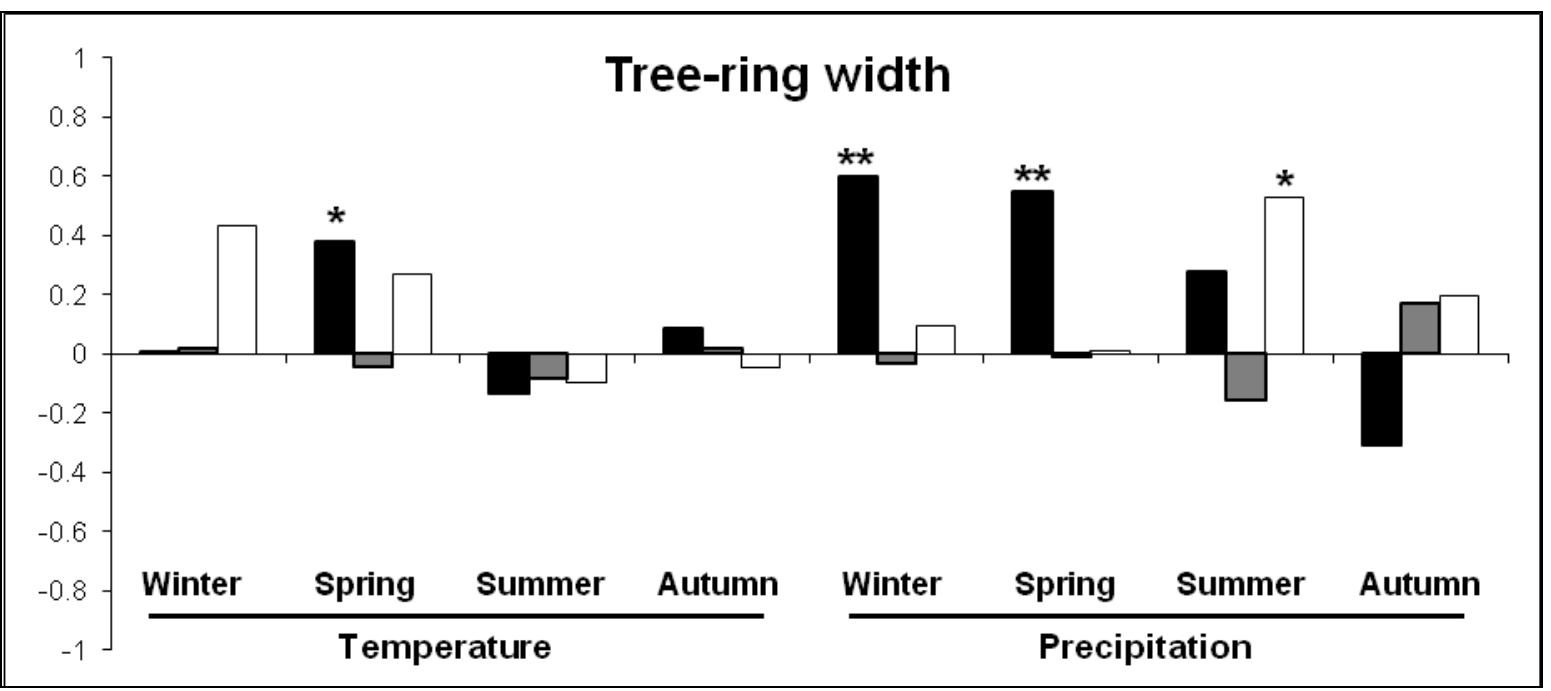

Fig. 2: Influence of the climatic variables (precipitation and mean temperature) over time on tree ring width of $P$. halepensis (black), P. pinaster (grey) and P. sylvestris (white). *: p-value >0.05; **: $p$-value $>0.005$.

Earlywood width of $P$. halepensis was positively correlated to precipitation during previous winter and spring ( $p$-values>0.005), while its latewood width was positively correlated to spring temperature ( $p$-value>0.05) and winter precipitation ( $p$-value>0.05). Earlywood width and latewood width of $P$. sylvestris were positively correlated with summer precipitation (Fig. 3). 

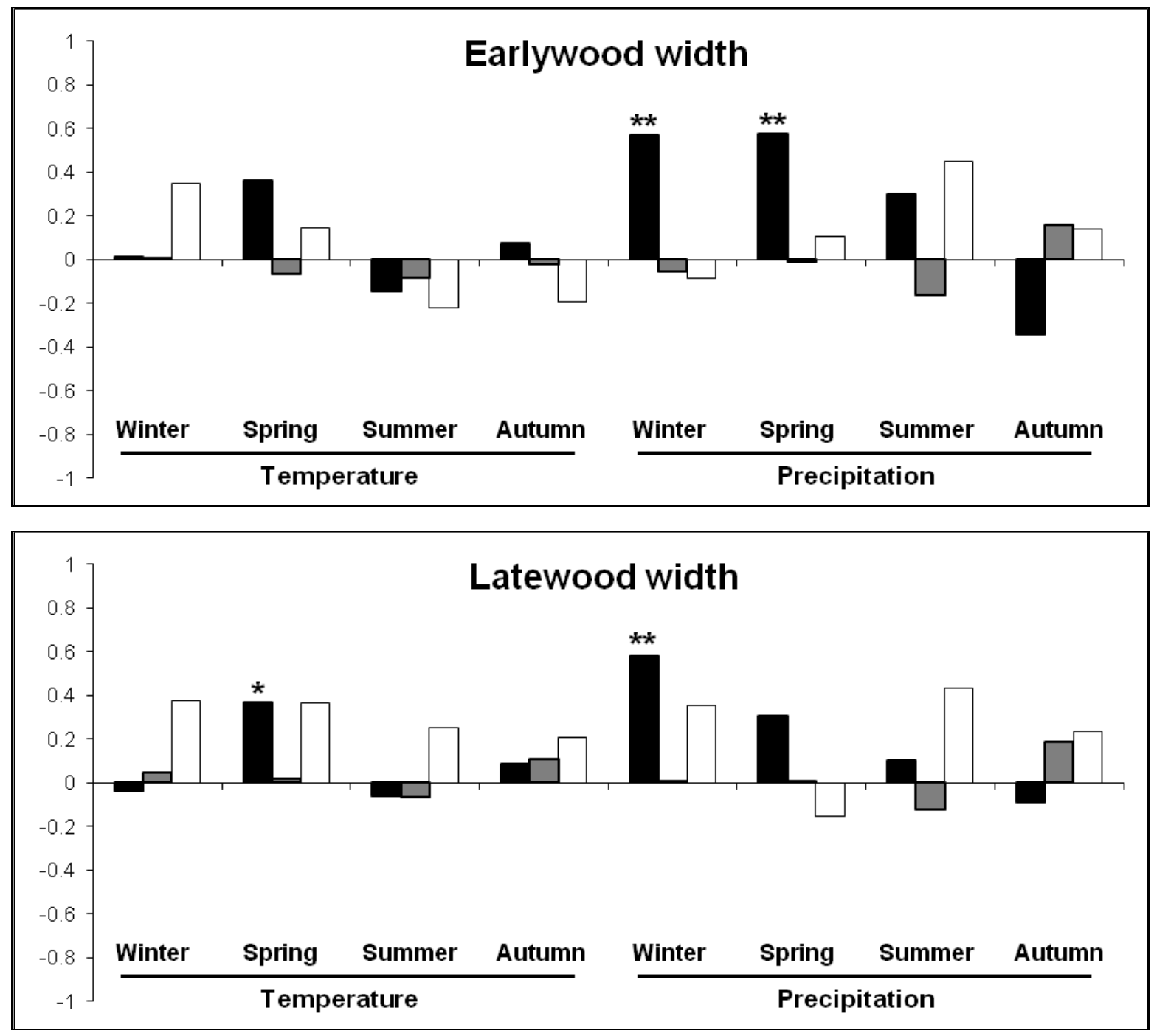

Fig. 3: Influence of the climatic variables (precipitation and mean temperature) over time on early wood and late wood width of P. halepensis (black), P. pinaster (grey) and P. sylvestris (white). *: pvalue $>0.05 ; * *$ : p-value $>0.005$.

Mean and maximum density followed different patterns on the three species, decreasing along time in $P$. pinaster and increasing in P. halepensis and P. sylvestris. Pinus halepensis showed higher values of mean density than the other two species and $P$. pinaster showed lowest values of maximum density than the other two species. Pinus pinaster experienced an abrupt decrease in the mean density pattern around 1970 and two moderate decreases en the maximum density pattern around 1970 and 1990. (Fig. 4). 

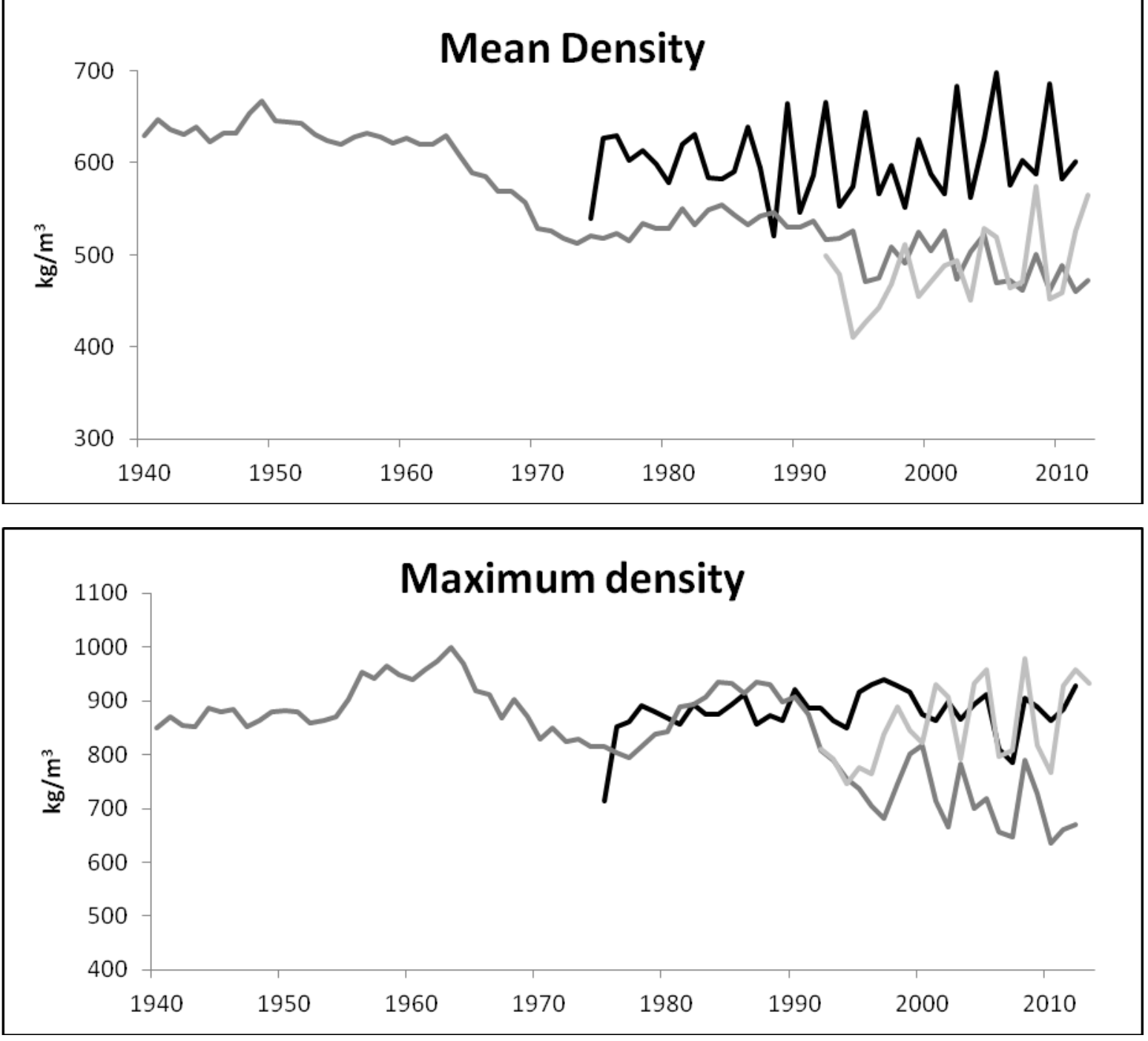

Fig. 4: Mean and maximum density patterns over time on P. halepensis (black), P. pinaster (dark grey) and P. sylvestris (light grey).

The analysis of the climate-density relationships showed that mean density of P. halepensis was negatively correlated to precipitation during previous winter ( $p$-value >0.05) and spring ( $p$-value $>0.005)$ and to spring temperature ( $p$-value>0.05). Mean density of $P$. sylvestris was positively correlated to autumn temperature (p-value>0.05) (Fig. 5). Pinus pinaster showed no significant correlations between mean density and climatic variables. 

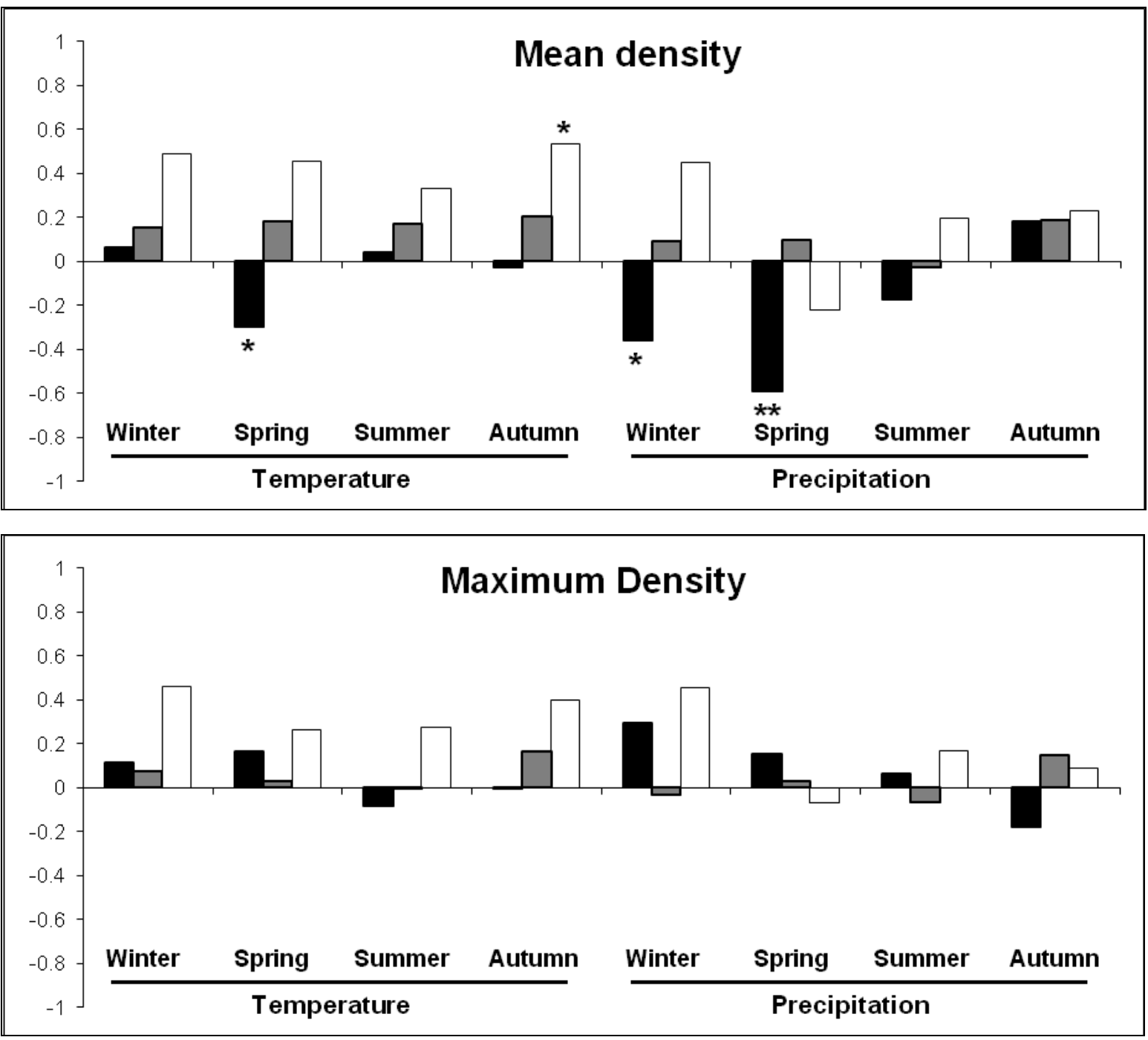

Fig. 5: Influence of the climatic variables (precipitation and mean temperature) over time on mean and maximum density of P. halepensis (black), P. pinaster (grey) and P. sylvestris (white). *: pvalue $>0.05 ; * *$ : p-value $>0.005$.

Early wood density was negatively correlated to precipitation during previous winter ( $p$ value $>0.05)$ and spring ( $p$-value $>0.005)$ and to spring temperature $(p$-value $>0.05)$ in $P$. halepensis; positively correlated to summer temperature in $P$. pinaster and positively correlated to spring and autumn temperature in P. sylvestris (Fig. 6). We calculated the growth and wood density trends of our sample and compared them to 5-year moving averages. 

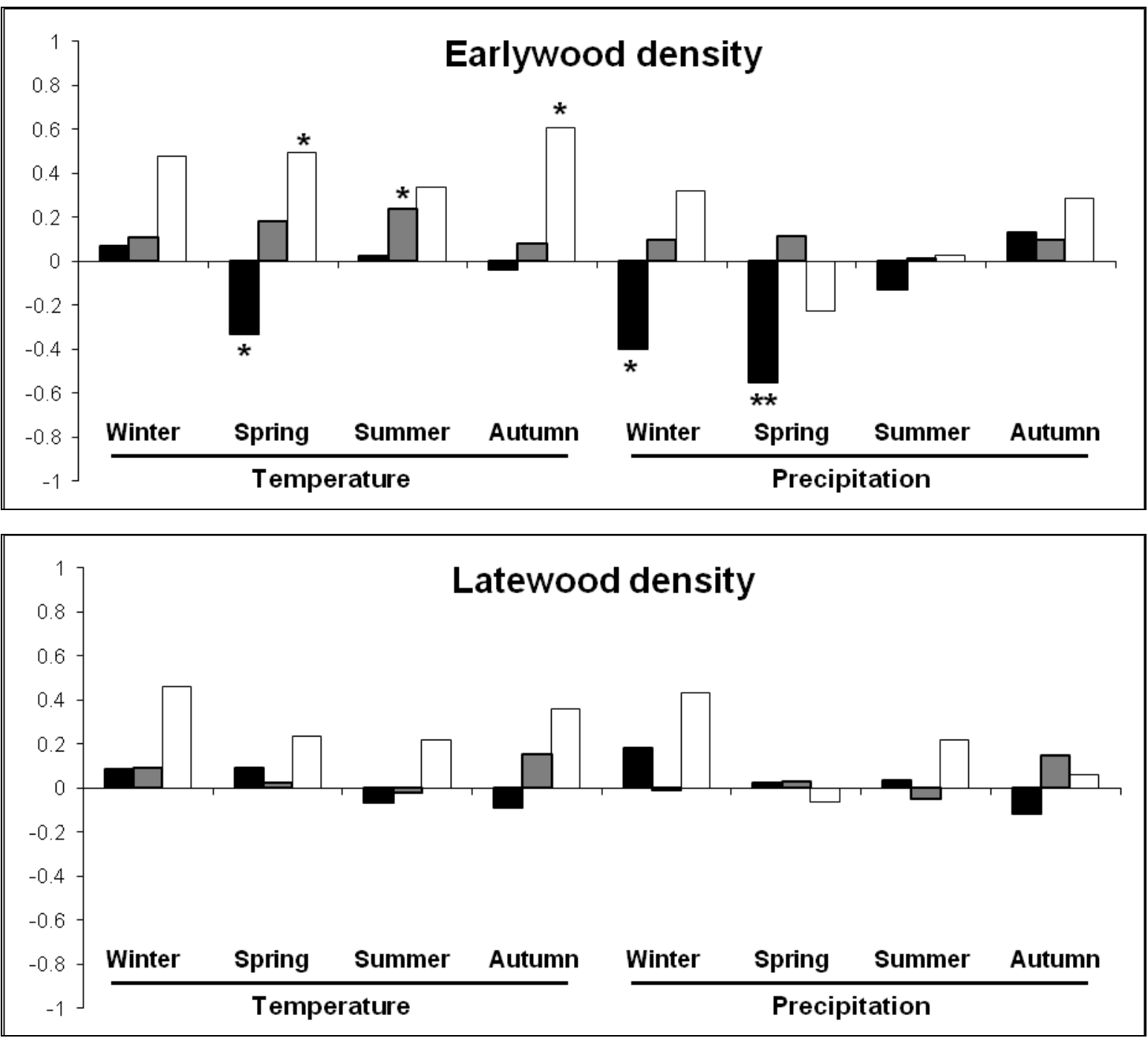

Fig. 6: Influence of the climatic variables (precipitation and mean temperature) over time on early wood and late wood density of P. halepensis (black), P. pinaster (grey) and P. sylvestris (white). *: p-value $>0.05 ; * *$ : p-value $>0.005$.

A decrease in growth rates was observed in the three species (Fig. 7), with high variability of the growth data especially during the most recent years (Standard deviation $=1.3 ; 0.7$ and $1 \mathrm{~mm}$ for $P$. halepensis, $P$. pinaster and $P$. sylvestris respectively). Pinus pinaster showed an irregular growth trend, with two maximum growth rates on the 1960s and the 1980s and a general decrease along time, especially during the most recent years. 


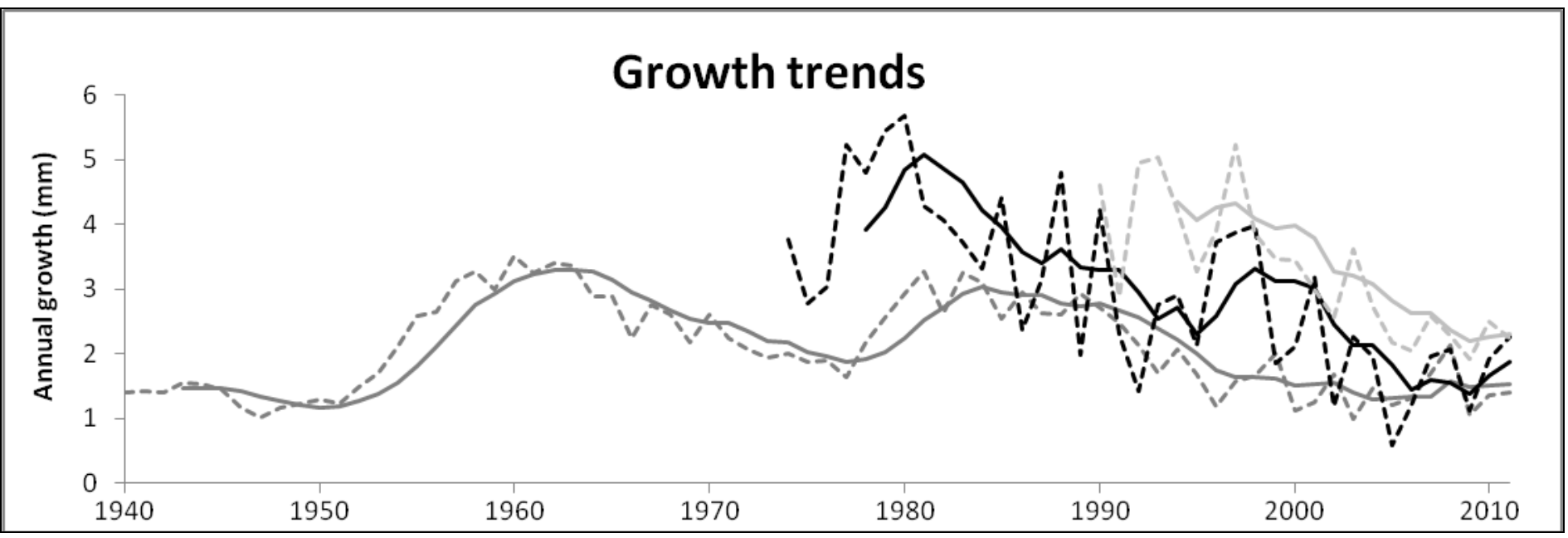

Fig. 7: Growth trends (dashed lines) of P. halepensis (black), P. pinaster (dark grey) and P. sylvestris (light grey). Full lines: 5-years moving averages.

However, the 5-year moving average followed the decreasing patterns on the three species with lower variability (Standard deviation $=1 ; 0.6$ and $0.8 \mathrm{~mm}$ for $P$. halepensis, $P$. pinaster and $P$. sylvestris respectively).

Mean density rates showed an increase in sensitivity during the most recent years (Fig. 8) (Standatd deviation $=41 ; 60$ and $42 \mathrm{~kg} / \mathrm{m}^{3}$ for $P$. halepensis, $P$. pinaster and $P$. sylvestris respectively). The 5-year moving weighted averages followed the same increasing ( $P$. halepensis and P. sylvestris) and decreasing ( $P$. pinaster) patters with lower variability of the data (Standatd deviation $=12 ; 57$ and $37 \mathrm{~kg} / \mathrm{m}^{3}$ for $P$. halepensis, $P$. pinaster and $P$. sylvestris respectively). 


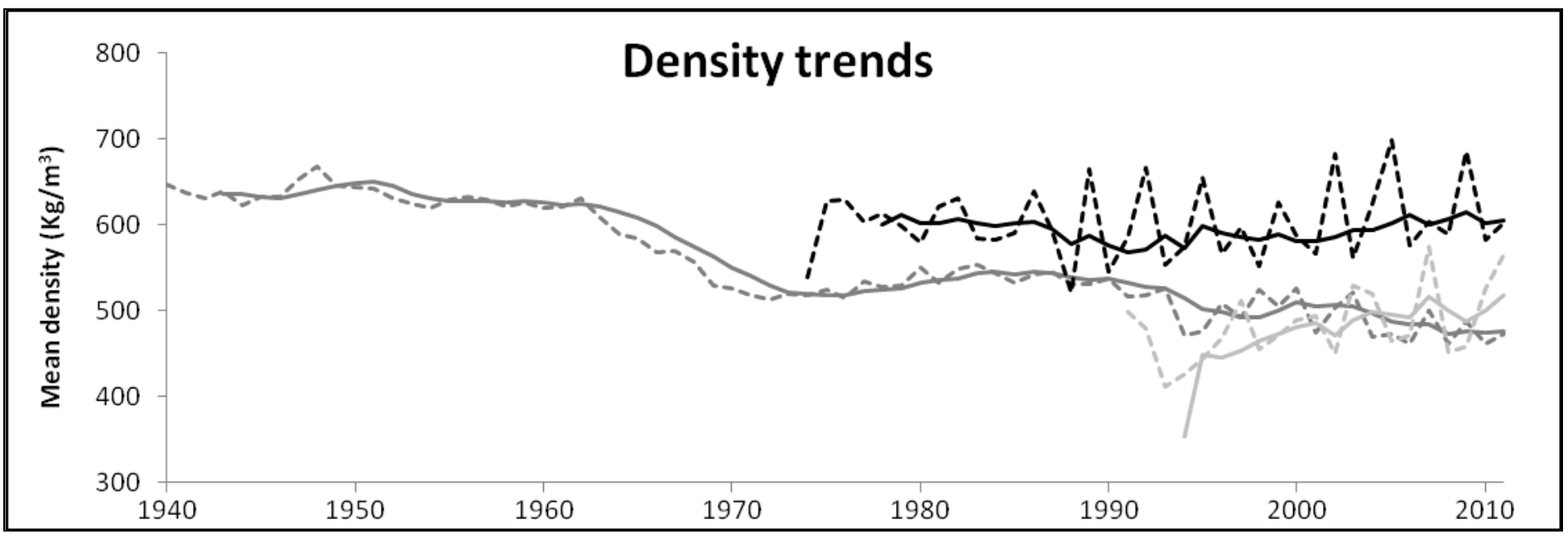

Fig. 8: Mean density trends (dashed lines) of P. halepensis (black), P. pinaster (dark grey) and P. sylvestris (light grey). Full lines: 5-years moving weighted averages.

\section{Discussion}

Precipitation is the main factor influencing tree growth of pine species in semiarid Mediterranean conditions (Raventós et al., 2001). Previous studies in Spain reported that tree-ring growth of $P$. halepensis was related positively to precipitations during winter previous to the growing season and spring (Olivar et al., 2012), integrating effects from previous year climatic and ecological conditions. Such physiological induced autocorrelation reflects the utilization of abundant carbohydrates stored towards the end or even after the growing season (Kozlowski and Pallardy, 1997; Büntgen et al., 2010). Pinus pinaster showed no significant correlations between tree-ring width and climatic variables. Previous studies reported that its growth is influenced by precipitations during winter previous to the growing season and spring in Spain (Bogino and Bravo, 2008) and Portugal (Vieira et al., 2009). However, the site selected for the present study is located at a more xeric site than the previously mentioned. Therefore, the relationships between growth and climate may vary. Radial growth of P.sylvestris was mostly influenced by summer precipitations agreeing with previous studies in Spain (Bogino et al., 2009).

Mean and maximum density levels increased outwards from the pith to the stem surface in $P$. halepensis and $P$. sylvestris, as found earlier by Kellomäki et al. (1999). However, $P$. pinaster showed a linear decrease in mean and maximum densities. Büntgen et al. (2010) suggested that this decrease might be related to (i) a systematic decrease in the ratio 
between cell wall size and lumen area with increasing tree age, or alternatively (ii) that the annual lignin content decreases with age.

Mean density was inversely correlated to precipitation in the previous winter and spring on $P$. halepensis. Rainfall in the early part of the growing season extends the production of earlywood, resulting in a lower density wood (Wimmer and Downes, 2003). Therefore, the negative effect of precipitation on wood density is accordingly consistent with its positive effect on radial growth. Gilmore (1968) also concluded that factors, which extend the production of earlywood, result in lower wood density wood. During the first part of the growing season, climatic variations affect radial enlargement, whereas during the later part of the growing season, climatic variations only affect the cell wall thickening process (Bouriaud et al., 2005; Büntgen et al., 2010). Detailed experiments showed that maximum tracheid production corresponded to maximum day length, thus allowing cell wall formation and lignification to be completed by the end of summer (Rossi et al., 2006).

Bouriaud et al. (2005) found a strong positive correlation between soil water deficit and wood density, which they attributed to temperature-mediated reductions in the radialgrowth rates due to an increasing soil-water deficit. Cell wall thickness variations play a major role in the wood density variations (Decoux et al., 2004). Rathgeber et al. (2006) suggested that wood density increase is mainly due to cell-wall thickening in tangential and radial directions as well as cell size reduction in radial direction. The reduction in tracheid radial enlargement might also be associated with thicker cell walls (Linares et al., 2009).

There is a general understanding that water stress has a major impact on various aspects of wood formation through direct effects of cell turgor as well as changes in hormonal balances and carbohydrate storage (Kramer, 1964). Similar effects of water availability on wood density were also observed for Picea abies (Wimmer and Downes, 2003, Bouriaud et al., 2005) and Pinus halepensis (Olivar et al., 2012), where wood density was found to increase in association with increased drought stress, creating a false ring. The positive effect of temperature on wood density is a consequence of its negative effects on radial growth rate (D’Arrigo et al., 1992; Yasue et al., 2000; Bouriaud et al., 2005). 
Maximum density of $P$. halepensis was positively correlated with climatic conditions favouring tree ring width, agreeing with the idea that favourable years with good climatic conditions at the beginning of the growing season increase the length of the growing period and, therefore, the duration of tracheid maturation, which determines the final cell wall thickness (Wodzicki, 1971; Horacek et al., 1999). The wall thickness of the latewood cells is the most important factor affecting the tree-ring maximum density (Yasue et al., 2000; Linares et al., 2009).

Especially for coniferous species, relationships between maximum latewood density and climatic variables such as late summer temperature have been established, and are widely used for climate reconstructions (Parker and Henoch, 1971, Schweingruber, 1978; Conkey, 1979; D’Arrigo et al., 1992; Briffa et al., 2001). However, these studies were conducted at temperate regions and not in the Mediterranean region. In our study only $P$. sylvestris, growing in higher altitude and having more favorable water conditions during summer showed a positive correlation between maximum latewood density and summer temperature, while $P$. halepensis and $P$. pinaster, subjected to summer water stress showed negative correlations between maximum latewood density and summer temperature. These negative correlations may be due to the low or inexistent growth rates of the trees in that period.

Due to the observed changes in growth-climate associations of pine species during the last part of the 20 ${ }^{\text {th }}$ century (Bogino and Bravo, 2008; Vieira et al., 2010; Campelo et al., 2013) we calculated the variance of the growth and wood density trends of our sample and compared them to a 5-year moving average (the typical modeling horizon) and a 5-year moving weighted average respectively. An increase in the climate sensitivity was observed in both trends during the last years, producing high irregularity in tree ring width and mean density. However, this irregularity is not observed in the 5-year moving interval, where low growth rates of some years are compensated with high growth of the surrounding years. These results indicate that, despite the increasing climate sensitivity of pine species during the most recent years, the trend in growth and mean density does not change in a 5-year interval. However, these inter-annual variability could have an effect on wood properties producing a loss of wood quality (Persson et al., 1999) 


\section{Conclusions}

Precipitation is the main climatic driver of the radial growth and wood density patterns for P. halepensis, $P$. pinaster and P.sylvestris in Spain. Climatic conditions increasing radial growth of $P$. halepensis reduced its mean density and increased its maximum density. Pinus sylvestris, growing in higher altitude and having more favorable water conditions during summer showed a positive correlation between maximum latewood density and summer temperature; while $P$. halepensis and $P$. pinaster, subjected to summer water stress producing low or inexistent growth rates of the trees in that period, showed negative correlations. Despite the increasing climate sensitivity of pine species during the most recent years, the trend in growth and mean density does not change in a 5-year interval. However, these inter-annual variability could have an effect on wood properties producing a loss of wood quality.

\section{References}

Bogino, S., Bravo, F., 2008. Growth response of Pinus pinaster ait. to climatic variables in central Spanish forests. Ann. For. Sci. 68: 506-518.

Bouriaud, O., Leban, J.-M., Bert, D., Deleuze, C., 2005. Intraannual variations in climate influence growth and wood density of Norway spruce. Tree Physiol. 25: 651-660.

Briffa, K.R., T.J. Osborn, F.H. Schweingruber, I.C. Harris, P.D. Jones, S.G. Shiyatov, S.G. and E.A. Vaganov, 2001. Low-frequency temperature variations from a northern tree-ring density network. J. Geophys. Res., 106, 2929-2941.

Bunn, A.G., 2008. A Dendrochronology Program Library in R (dplR). Dendrochronolgia, 26: $115-124$.

Büntgen, U., Frank, D., Trouet, V., Esper, J., 2010. Diverse climate sensitivity of Mediterranean tree-ring width and density. Trees 24: 261-273.

Campelo, F., Nabais, C.; Freitas, H., Gutiérrez, E., 2007. Climatic significance of tree-ring width and intra-annual density fluctuations in Pinus pinea from a dry Mediterranean area in Portugal. Ann. For. Sci. 64: 229-238. 
Cherubini, P., B.L. Gartner, R. Tognetti, O.U. Bräker, W. Schoch \& J.L. Innes. 2003. Identification, measurement and interpretation of tree rings in woody species from Mediterranean climates. Biol. Rev. 78: 119-148. Fahn, A. \& E. Zamski. 1970.

Conkey, L. A., 1979. Response of tree-ring density to climate in Maine, U.S.A. Tree-Ring Bull. 39: 29-38

D’Arrigo, R.D., Jacoby, G.C., Free, R.M., 1992. Tree-ring width and maximum latewood density at the North American tree line: parameters of climatic change. Canadian Journal of Forest Research 22(9): 1290-1296.

De Luis, M., Gričar, J., Čufar, K., Raventós, J. 2007. Seasonal dynamics of wood formation in Pinus halepensis from dry and semi-arid ecosystems in Spain, IAWA Journal 28: 389404.

Decoux, V., Varcin, E., Leban, J.M., 2004. Relationships between the intraring wood density assessed by X-ray densitometry and optical anatomical measurements in conifers. Consequences for the cell wall apparent density determination, Ann. For. Sci. 61: 251262.

Fritts, H.C., Vaganov, E.A., Sviderskaya, I.V., Shashkin, A.V. 2001. Climatic variation and tree-ring structure in conifers: empirical and mechanistic models of tree-ring width, number of cells, cell size, cell-wall thickness and wood density. Climate Research 1: 97116.

Fritts, H. C., 2001. Tree rings and climate. The Blackburn press, London.

Gilmore, A.R., 1968. Geographic variation in specific gravity of white pine and red pine in Illinois. For. Prod. J. 18: 49-51.

Horacek, P., Slezingerova, J., Gandelova. L., 1999. Effects of environment on the xylogenesis of Norway spruce (Picea abies [L.] Karst.). In Tree Ring Analysis: Biological, Methodological and Environmental Aspects. Eds. R. Wimmer and R.E. Vetter. CAB International, Wallingford, Oxon, UK, pp 33-53. 
IPCC. 2001. Climate change 2001: the scientific basis. In Contribution of Working Group I to the Third Assessment Report of the IPCC. Cambridge University Press, Cambridge, 83 p.

Kellomäki, S., Ikonen, V-P., Peltola, H., Kolström, T. 1999. Modelling the structural growth of Scots pine with implications for wood quality. Ecological Modelling 122 (1-2): 117-134.

Kramer, P.J., 1964. The role of water in wood formation. In Zimmermann M.H. (ed.), The formation of wood in forest trees. Academic Press, New York, London, pp. 519-532.

Kozlowski, T.T., Pallardy, S.G., 1997. Physiology of woody plants. Academic Press, San Diego, $657 \mathrm{p}$.

Leban, J.-M., Pizzi, Q., Wieland, S., Zanetti, M., Properzi, M., Pichelin. E., 2004. X-Ray microdensitometry analysis of vibration- welded wood. J. Adhes. Sci. Technol. 18: 673685 .

Linares J.C., Camarero, J.J., Carreira, J.A., 2009. Plastic responses of Abies pinsapo xylogenesis to drought and competition. Tree Physiology 29: 1525-1536.

Mäkinen, H., Nöjd, P., Mielikäinen, K., 2000. Climatic signal in annual growth variation of Norway spruce (Picea abies) along a transect from central Finland to the Arctic timberline. Can. J. For. Res. 30: 769-777.

Mäkinen, H., Nöjd, P., Mielikäinen, K., 2001. Climatic signal in annual growth variation of Norway spruce (Picea abies) in southern Finland. Trees 15: 177-185.

Mäkinen, H., Nöjd, P., Saranpää, P., 2003. Seasonal changes in stem radius production of new tracheids in Norway spruce. Tree Physiol. 23: 959-968.

Martin-Benito, D., Cherubini, P., del Rio, M., Cañellas, I., 2008. Growth response to climate and drought in Pinus nigra arn. Trees of different crown classes. Trees 22: 363373. 
Martinez-Meier, A., Sanchez, L., Pastorino, M., Gallo, L., Rozenberg, P., 2008. What is hot in tree rings? The wood density of surviving Douglas-firs to the 2003 drought and heat wave. Forest Ecology and Management 256: 837-843.

Mothe, F., Duchanois, G., Leban, J.-M., Nepveu, G., 1998. Analyse microdensitométrique appliquée au bois: une méthode de traitement des données aboutissant B la description synthétique et homogène des profils de cerne (programme CERD). Ann. For. Sci. 55: 301315.

Olivar, J., Bogino, S., Spiecker, H., Bravo, F., 2012. Climate impact on growth dynamic and intra-annual density fluctuations in Aleppo pine (Pinus halepensis) trees of different crown classes. Dendrochronologia 30, Issue 1: 35-47.

Parker, M. L., Henoch, W. E. S., 1971. The use of Englemann spruce latewood density for dendrochronological purposes. Can. J. For. Res. 1 (2): 90-98.

Papadopoulos, A.M., Serre-Bachet, F., Tessier, L. 2001. Tree ring to climate relationships of Aleppo pine (Pinus halepensis Mill.) in Greece. Ecologia Mediterranea, 27 (1): 89-98.

Papadopoulos, A., Tolica, K., Pantera, A., Maheras, P. 2008. Investigation of the annual variability of the Aleppo pine tree-ring width: the relationship with the climatic conditions in the Attica basin. Global nest journal 11: 583-592.

Persson, B., Persson, A., Stahl, E., Karlmats, U. 1995. Wood quality of Pinus sylvestris progenies at various spacings. Forest Ecol Manage 76: 127-138

Raventós, J., de Luís, M., Gras, M., Cufar, K., González-Hidalgo, J., Bonet, A., Sánchez, J., 2001. Growth of Pinus pinea and Pinus halepensis as affected by dryness, marine spray and land use changes in a Mediterranean semiarid ecosystem. Dendrochronologia 19: 211-220.

Rathgeber, C., Decoux. V., Leban, J-M. 2006. Linking intra-tree-ring wood density variations and tracheid anatomical characteristics in Douglas fir (Pseudotsuga menziesii (Mirb.) Franco). Ann. For. Sci. 63: 699-706. 
Rathgeber C, Nicault A, Guiot J, Keller T, Guibal F, Roche P. 2000. Simulated responses of Pinus halepensis forest productivity to climatic change and $\mathrm{CO} 2$ increase using a statistical model. Global and Planetary Change 26: 405-421.

Rathgeber C, Nicault A, Kaplan JO, Guiot J. 2003. Using a biogeochemistry model in simulating forests productivity responses to climatic change and [CO2] increase: example of Pinus halepensis in Provence (south-east France). Ecological Modelling 166: 239-255.

Rathgeber CBK, Misson L, Nicault A, Guiot J. 2005. Bioclimatic model of tree radial growth: application to the French Mediterranean Aleppo pine forests. Trees-Structure And Function 19: 162-176.

Roderick, M.L., Berry, S.L. 2001. Linking wood density with tree growth and environment: a theoretical analysis based on the motion of water. New Phytologist 149: 473-485.

Rossi, S., Deslauriers, A., Anfodillo, T., Morin, H., Saracino, A., Motta, R., Borghetti, M., 2006. Conifers in cold environments synchronize maximum growth rate of tree-ring formation with day length. New Phytologist 170: 301-310

Sass, U., Eckstein, D., 1995. The variability of vessel size in beech (Fagus sylvatica L.) and its ecophysiological interpretation. Trees - Structure and Function 9(5): 247-252.

Stokes, M., Smiley, T., 1968. An introduction to tree-ring dating, University of Arizona press, Tucson, USA.

Schweingruber, F.H., H.C. Fritts, O.U. Bräker, L.G. Drew \& E. Schär. 1978. The X-ray technique as applied to dendroclimatology. Tree-Ring Bull. 38: 61-91.

Schmitt, U., Möller, R., Eckstein, D., 2000. Seasonal wood formation dynamics of beech (Fagus sylvatica L.) and black locust (Robinia pseudoacacia L.) as determined by the “pinning'” technique. Journal of Applied Botany 74: 10-16.

van der Maaten, E., van der Maaten-Theunissen, M., Spiecker, H., 2012. Temporally resolved intra-annual wood density variations in European beech (Fagus sylvatica L.) as affected by climate and aspect. Annals of Forest Research 55: 105-116. 
Vieira, J., Campelo, F., Nabais, C., 2009. Age-dependent responses of tree-ring growth and intra-annual density fluctuations of Pinus pinaster to Mediterranean climate. Trees 23: 257265

Wimmer, R., Downes, G.M., 2003. Temporal variations of the ring width-wood density relationship in Norway spruce grown under two levels of anthropogenic disturbance. IAWA J. 24: 53-61.

Wodzicki, T.J. 1971. Mechanism of xylem differentiation in Pinus sylvestris L. J. Exp. Bot. 22: $670-687$.

Yasue, K., Funada, R., Kobayashi, O., Ohtani. J., 2000. The effect of tracheid dimensions on variations in maximum density of Picea glehnii and relationships to climate factors. Trees-Struct. Funct. 14: 223-229. 
Olivar (2013)

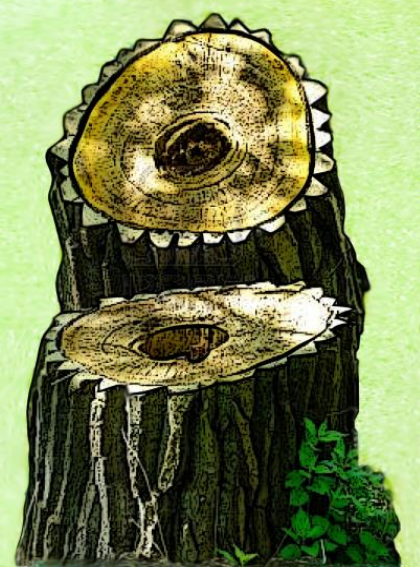

